\title{
THE SPIRIT OF
}

ASSOCIATION

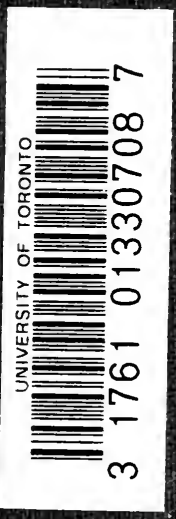




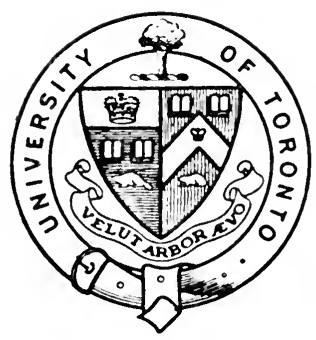

Presented to the

\section{UNIVERSITY OF TORONTO \\ LIBRARY}

by the

ONTARIO LEGISLATIVE

LIBRARY

1980 
Digitized by the Internet Archive in 2007 with funding from

Microsoft Corporation 
THE SPIRIT OF ASSOCIATION 



\title{
THE SPIRIT OF ASSOCIATION
}

BEING SOME ACCOUNT OF THE GILDS, FRIENDLY SOCIETIES, CO-OPERATIVE MOVEMENT AND TRADE UNIONS OF GREAT BRITAIN

\section{BY M. FOTHERGILL ROBINSON}

\author{
AUTHOR OF "THE POOR LAW ENIGMA"
}

"The mere founding, for example, of a voluntary society for any given purpose evolves out of the primary elements of human character a latent force of the most powerful kind-namely, the motive, the sentiment, the feeling, the passion as it often is of the spirit of association." The Reign of Law.-DURE OF ARGYLL.
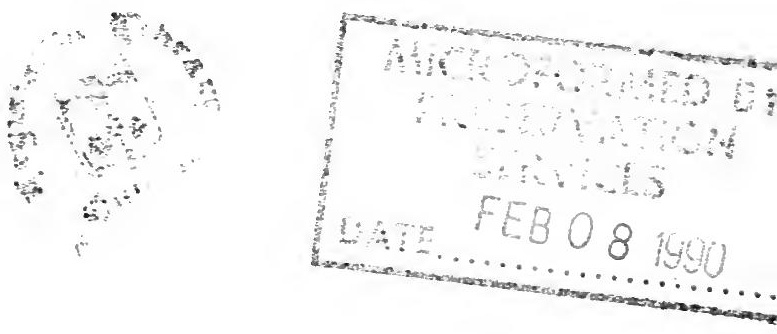

LONDON :

JOHN MURRAY, ALBEMARLE STREET, W. 


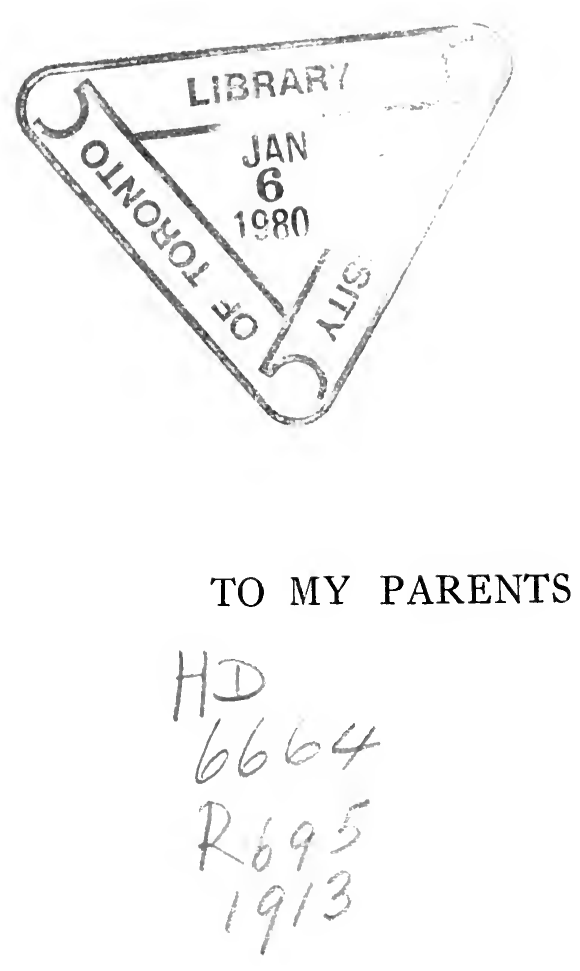




\section{CONTENTS}

INTRODUCTION $\quad-\quad-\quad-\quad-\quad-\quad-\quad-\quad-\quad \begin{array}{r}\text { PAGE } \\ \text { X }\end{array}$

\section{CHAPTER I}

THE ORIGIN OF ENGLISH GILDS

State intervention in British voluntary assurance-Past achievements of the Spirit of Association-Origin of the Gilds - The Roman Collegia-Fraternities of Ancient GreeceEnglish Gilds-The Frith or Peace Gilds-The Cnighten Gild-King Canute and Viking piracy - - - -

\section{CHAPTER II}

\section{RELIGIOUS AND SOCIAL GILDS}

The Inquiry of 1388-Gilds of Abbotsbury and ExeterCharacteristic features of Religious and Social GildsMembership-Payments-Meeting-days-Religious activities-Burials-Pilgrimages-Chauntries-Pageants - Plays - Church repairs-Bell-ringing-Mutual aid-Influence on subsequent relief-Doles - Visitation of prisoners-Services to education-Institution of almshouses-The Reformation -Annihilation of Religious Gilds - - _ - - 16

\section{CHAPTER III}

\section{TRADE GILDS}

Trade Gilds to be judged in relation to contemporary conditions - Rise of the Merchant Gilds-Causes which produced them - Constitution and functions of Merchant Gilds-Protection to local trading-Fair dealing enjoined-Charitable and Religious offices-The Merchant Gilds and the municipal constitution-Influence on the growth of the towns - 
TRADE GILDS (continued)

Rise of the Craft Gilds-Growth of industrial labour-Encroachments on powers and privileges of the Merchant GildsAction of the legislature-Degeneration and disappearance of Merchant Gilds-Merchants of the Staple and Merchant Adventurers-Development of the Craft Gilds from the fourteenth century-Associations of Journeymen-Rise of a "working-class"-Use of the strike-Subordination of Journeymen's Associations in the Gild System during the sixteenth and seventeenth centuries - - $\quad-\quad-\quad-5^{8}$

\section{CHAPTER V}

\section{FUNCTIONS OF THE CRAFT GILDS}

Regulation of processes-Inspection by "searchers"-Prohibition of night-work, etc.-Protection of the Consumer - Mediæval bakers and the pillory-Courts of the Craft Gilds-Punishments-Gild regulation of apprenticesElizabethan Statute of Apprentices-Undue Restrictions -The Masterpiece, etc.-Social activities-Triumphant shows-Setting out the watch-Defence of the City-The Midsummer Watch-Charitable work of the City Companies and Crafts

\section{CHAPTER VI}

\section{DECLINE OF THE CRAFT GILDS}

Internal causes of degeneration-The economic changes which broke down the Gild System-Expanding enterpriseGrowth of the towns-National trade superseded by local trade-Centralisation of Government-Dawn of the Industrial Revolution-Estimate of the Gild System - - 100

\section{CHAPTER VII}

THE INDUSTRIAL REVOLUTION

Unrestricted competition-The "domestic system"-Introduction of machinery-Effects on industry-Development of means of communication-The "Agrarian Revolution" 
-Effects of the Industrial Revolution on wage-earnersThe "golden age"-Abuse of child labour-Parish apprentices-Birth of Factory legislation-Children's hours of labour-Effects on physical development and education -Insanitary towns-The "truck" and "cottage" systemsThe "cash-nexus" - Class cleavage in town and countryFluctuations in trade-Time and natural consequence as teachers-Impulse to the Factory Acts and associative effort

\section{CHAPTER VIII}

\section{THE FRIENDLY SOCIETY MOVEMENT}

Democratic effort in three directions supplemented one another -Rise of the Friendly Societies-Theories of mythical origin-"Boxes"-Huguenot refugees-Village ClubsCharacter of the Mutual help afforded-Malingering-Rise of the Oddfellows and Foresters-Friendly Societies and the Legislature-Corresponding Societies Act-Seditious Meetings Act-Recognition under Rose's Act-The experimental period-Causes of insolvency-Permissive Legislation-Registration-Royal Commission of $1870-$ Friendly Societies Act of $1875^{-}$

\section{CHAPTER IX}

\section{EXPANSION AND REFORM}

Frequent failure and unsound financial basis-Levy SocietiesDividing Societies-Permanent Societies-Burial Societies - "The Hearts of Oak"-The Affiliated Orders-Vital Statistics-The Ratcliffe " Tables"-Progress and financial reform-The movement abroad-Social Value of the Friendly Society movement - _ _ _ - - 160

\section{CHAPTER X}

\section{THE CO-OPERATIVE MOVEMENT UNTIL I 863}

Co-operation representing the expression of a desire for social betterment-Robert Owen-New Lanark-Owen's social faith-Influence on his age-The first Co-operative movement-Flour mills and Baking Societies-Union Shops- 
Chartism-Riots-Kennington Common and fiasco-The Christian Socialists-Self-governing workshops-Parson Lot-The Magna Charta of Co-operation-Influence of the Christian Socialists-The Rochdale Pioneers and the Store movement-Phenomenal success-Dividend on purchase -Influence of Co-operation up to 1863 - - - I8I

\section{CHAPTER XI}

THE CO-OPERATIVE MOVEMENT (continued)

Production for distribution-The Wholesale Federations-The Co-operative Union-The Labour Co-partnership Association-Agricultural Organisation-Co-operation and the consumers-Democratic machinery of managementThrift-Cash-payments-Education-The Women's Guild and the poorer classes of society-Co-operative Stores and their employees-Profit-sharing-General conditions of employment

\section{CHAPTER XII}

\section{CO-OPERATION AND AGRICULTURE}

Agricultural Co-operation in Ireland-Its economic value and educational influence-Co-operative Agriculture in Great Britain-Aims and methods-Hopes for future progress - 22 I

\section{CHAPTER XIII}

\section{CO-PARTNERSHIP AND INDUSTRIAL UNREST}

Causes of the present cycle of unrest-Cost of living-No relative increase in wages-Loss of faith in normal Trade Union policy-Co-partnership as a remedy-Workers' Societies offer no immediate solution-Characteristics of complete Co-partnership-Trade Union objections and their answer-Some merits of Co-partnership and Profitsharing

\section{CHAPTER XIV}

TRADE UNIONS (1700-I 830)

Causes which produced Trade Unionism-Increase in the number of permanent wage-earners-The small master and 
organisation-Wealthy master clothiers-Disappearance of Gild restrictions-Pressure of competition on the wageearners-Laissez-faire and association-First developments of Trade Unionism-Houses of Call-Hostile attitude of employers-The Combination Laws-Their effects on Trade Unionism-Misuse of the forces of association-Francis Place and the Legislature-Repeal of the Combination Laws in 1824 -Outbreak of strikes-Freedom in jeopardyLegal position of the Unions in 1825 - - - - - 248

\section{CHAPTER XV}

\section{TRADE UNIONS (I830-I880)}

The first New Unionism-Robert Owen and the "Trades Union " cause-The Dorchester Labourers-Botany BayDevelopment of a wiser policy_- Old Unions "- The strike of 1859 and public interest-The Document-Able Trade Union leaders-First signal legislative victory-The Sheffield outrages-The Royal Commission of 1867 - The two Reports-Legislation and the stimulus to Trade Unionism-Joseph Arch and the agricultural labourersThe check in 1874 -Labour representatives in Parliament - 267

\section{CHAPTER XVI}

THE AIMS AND FUNCTIONS OF TRADE UNIONS

Friendly benefit work-Divergence in theory from that of Friendly Society assurance-Dispute benefit-Out-of-work benefit-The appeal to Parliamentary action-Political machinery of Trade Unionism-Influence of the Trade Union vote-Collective bargaining-Arbitration and Conciliation-Conciliation Act of 1896 - Restriction of numbers -Limitation of apprenticeship and boy labour-Regulations with regard to non-unionists - $\quad-\quad-\quad-287$

\section{CHAPTER XVII}

\section{NEW UNIONISM AND AFTER}

Internecine warfare-Fusion of Socialism and Trade Unionism -Aims of New Unionism-Reliance on Municipal and Parliamentary action-The solidarity of labour-The Dock strike of ' $89-$ Failure to realise the hopes of maintaining permanent organisations among the lower grades of labour 
-Growth of Trade Unionism-Employers' Associations-

Federation-The Labour Party-Recent legal decisionsThe Taff Vale case-Injurious effects of the Trade Disputes Act-The Osborne judgment-Trade Union (No. 2) BillSyndicalism and the threefold disillusionment-Revolutionary aims of the Syndicalist-The "general strike" and guerilla warfare-Influence of Syndicalism on British Trade Unionism

\section{CHAPTER XVIII}

THE LINE OF ADVANCE

Divergent principles and methods of Trade Unionism-Variations in type-The influence of leadership and its difficulties-Influence of trade fluctuations on policy-Variations in policy with regard to non-unionists, employers, etc. -The sectional aim of Trade Unionism-Want of appreciation of the economic factors in industry-The dignity of the worker and the dignity of work-Individual efficiency -Trade Unionism and mediocrity-Reduced opportunities of employment for older men-Subordination of means to ends with respect to non-unionists-The other side of the account-Labour's ideal-Contributions to industrial efficiency-Organisation a valuable basis for conciliationBalance of evidence in favour of organisation of labourVoluntary association capable of doing yet more for wageearners-Some reforms suggested-The under-world of labour-The Trade Boards Act-The employer's contribution-The appeal of the wage-claim - - - 343

\section{Conclusion}

Appendices-

A. Colonial Industrial Arbitration and Conciliation- $\quad-369$

B. The Trade Boards Act and the Minimum Wage - $\quad-378$

C. The Growth in Thrift since 1876 - - - - $\quad-386$

Books of Reference - $\quad$ - $\quad$ - $\quad$ - $\quad$ - $\quad$ - $\quad$ - 391

INDEX 


\section{INTRODUCTION}

ThE circumstances under which this volume has been prepared have made it impossible for me to undertake any original research, or any examination of ancient records. Much that concerns British associative effort yet remains imperfectly explored. Though the labours of economists and historians have been increasingly fruitful in this direction in recent years, a good deal that is germane to the subject lies hidden. The Friendly Societies have not yielded all their buried treasures, and further investigations respecting the Gild organisations and Journeymen's associations would doubtless be well repaid.

Though it was necessary for me to confine myself to the more beaten tracks, it appeared to me that a short account of the four great forms of spontaneous voluntary associations in Great Britain might prove useful. The perplexing industrial struggles which agitate society to-day have their roots in the conflicts of past ages, and it is necessary to invoke the witness of history to throw light upon the impulses which guide the great democratic movements of our own times.

How the more satisfactory distribution of wealth, which ethical considerations demand, may be effected, remains as one of the problems which clamours urgently for solution. Voluntary associative effort, with its 
enormous potentialities for raising character, stimulating efficiency, and modifying economic conditions, is one of the great forces which is capable of helping to find an answer. Its manifestations thus establish a claim to be studied carefully.

I have to acknowledge the full extent of my debt to a number of writers, and have appended a list of the books, articles, reports and pamphlets which I have found especially useful. I cannot forbear from mentioning here my special obligations to the researches of Dr. Gross, and Professors Ashley and Unwin with respect to English Gilds; to the writings of Mr. Ernest Aves and Mr. C. R. Fay on the Co-operative Movement; and to the exhaustive works on Trade Unions by Mr. and Mrs. Sidney Webb. Much of the matter to be found in Chapters XIV and XV is drawn from information which is contained in their History of Trade Unionism. I desire also to acknowledge my abiding debt to $\mathrm{Mr}$. Arnold Toynbee's Industrial Revolution. Finally, I would express my gratitude to those who have kindly supplied me with information, to those who have helped me with valuable criticism and advice, and to Mr. Jesse Argyle for his help in the correction of the proofs, and for preparing the index.

London, April, I913.

M. F. R. 


\section{THE SPIRIT OF ASSOCIATION}

CHAPTER I

\section{THE ORIGIN OF ENGLISH GILDS}

WE stand at the parting of the ways. The purely voluntary character of associative effort in Great Britain for mutual assurance is now a thing of the past. The State has stepped in, and by the passing of the Insurance Act confers on the one hand certain benefits, and on the other makes a demand to exercise a definite control over all societies which afford Friendly benefits, and which bring themselves as "approved" bodies within the scope of the Act.

To what extent voluntary effort would, in the fullness of time, have achieved the economic security of the working classes must now remain purely problematical. The strides which have been made in this direction during the last century certainly give colour to the view that, with a task made easier in the future by education, an increased attention to sanitation, and a growing knowledge of actuarial science, progress, even if slow, might have been continuous.

The question of accepting State aid on condition of submitting to increased State control was not new to the Friendly Societies when Mr. Lloyd George introduced the Insurance Bill in the House of Commons in I9II. Two 
powerful tendencies had long been at work. On one side were ranged those whose strong desire for independence and jealousy of State interference prompted them to resist and distrust all State action in the matter, on the other side were those who felt that the complex risks of modern society could never be satisfactorily met by insurance without State intervention. Arnold Toynbee voiced the need for Government co-operation in the work of the great Friendly Societies, and urged that grants-in-aid should be made to them under carefully considered conditions of State audit. He was careful, however, to add that such aid should not be invoked on " a large and monstrous scale," and should not interfere with the great voluntary institutions which have built up our nation.

Among those standing for independence were many who felt with Mr. Cowell, the author of one of the Jackson Prize Essays on Friendly Societies, published in 1885. He wrote: "It is now felt that the laws imposed by moral suasion are likely to be more beneficial and permanent than any other. When arbitrary authorityeither local, municipal, or Parliamentary-usurps the place of voluntary effort and personal exertion, it tends to enervate the moral tone of a nation, and weaken that sense of social dignity which every man ought to encourage, but which can only be maintained by those who are least dependent upon the favours of others."

The question as to which course would have been the best for the morale and the economic stability of the nation is a vitally important one. Voluntary effort throughout its entire history has been profoundly influenced by the ebb and flow of State intervention. The future of associative effort depends in no small degree on the wisdom which the statesmen of the future may 
exhibit in invoking State aid without quenching the forces of spontaneous organisations.

The task I have set myself in the present volume is to examine some of the achievements of the Spirit of Association in our country in the past : to show something of the way in which our people from earliest times have combined to provide mutually for sickness, burial, accident, fire, shipwreck and disaster: to place themselves under common rules to keep the peace, to avenge violence, to control the conditions of labour and trade, and to promote laws to mitigate the effects of unbridled competition. My object will be to attempt to show in some degree how great is our debt to associative effort, and how potent a factor it has been in our national progress, in spite of the excesses, tyrannies and violence which have now and again marred its records.

We shall see that by its means character has been trained and raised, a religious spirit has been manifested, discipline has been enforced, and also that the various forms of association in England have served as schools of citizenship. Through its ministrations vast numbers have been rendered independent during periods of sickness and unemployment, who would otherwise have required State maintenance.

Our Legislature from earliest times has been indebted to the example of the voluntary societies. The town governors and municipal authorities doubtless occasionally adopted Gild methods, and so made regulations for the towns, and statesmen in their turn have based laws on the enactments of the governors of the towns of England. The process has therefore sometimes been, first the birth of an idea and its development in the ordinances of a Gild, then its adoption and enactment by 


\section{4 \\ THE ORIGIN OF ENGLISH GILDS}

the authorities of the towns, and lastly its final expression on the Statute Book at Westminster.

It must further be noted that in certain cases the voluntary associations have performed duties delegated to them by the municipal bodies, and have so borne an important share in municipal government. The record is a notable one, and an examination in some detail of the series of movements which have achieved so much is necessary to a true understanding of our national history.

It is clear that the historical sense is no longer satisfied with stirring accounts of valiant or of evil deeds, of the clash of armies on the battle-fields, with gossiping accounts of court and Church intrigues, and even with an understanding of the growth of government by laws and statutes. It now demands a knowledge of the inner life and toil of the countless multitudes, who have borne their part in building up our commerce and our wealth, and who have accomplished silent and bloodless revolutions, the true meaning of which has often been unperceived until generations after they have passed away. One of the duties of the sociologist is to interpret this inner life, to take account of these silent forces, these moving causes, and so to endeavour to learn what history may teach. So only by faithful study of the social and economic phenomena of the past can he equip himself to estimate rightly the complicated issues of the present, or hope to throw light on the pressing anxieties of the immediate future.

The old records and ordinances relating to the Gilds will be found to have an enormous value in contributing to make the dry bones of history live. The human element is ever present in them, and by their means we 
may conjure up a vision as to the manner in which these dead men and women lived, worked, and worshipped; with what ceremonial they were buried, and how for long years men prayed for the welfare of their departed souls.

In studying the Friendly Societies we shall watch the growth of a movement resulting from the practical determination that the working man should no longer be the unprepared victim of "the slings and arrows of outrageous fortune." In the Co-operative movement we shall note enthusiastic toil for a great ideal. In the rise of Trade Unionism we shall trace, in addition to Friendly Society benefit work, corporate efforts by collective bargaining and more belligerent methods to secure improved terms for labour.

Varying conditions have produced various forms of associative effort. Injustice and oppression have evoked militancy, whereas periods of acquiescence in comparatively satisfactory conditions have afforded the opportunity for increased efforts to be made towards securing economic independence, by means of insurance against the ills and mischances to which flesh is heir. It is almost impossible to over-estimate the importance of the contribution to the welfare of the body politic made by the huge network of voluntary associations which has been developed in England from Anglo-Saxon times. Voluntary effort has promoted order and fostered liberty. A recent writer in speaking of the effect of the Gilds on Europe generally has written: "It was precisely by the union of many individuals to form a solid, united corporation that the Teuton won back the freedom which he had lost through contact with the Roman Empire. But for the innate instinct which led the Teutons to co-operate, they would have remained just as much 
slaves as the Egyptians, Carthaginians, Byzantines, or the subjects of the Khalif. The isolated individual is to be compared to a chemical atom with little cohesive power; it is absorbed, destroyed. By adopting, of his own free will, a law, and submitting unconditionally to it, the individual assured to himself a secure and decent livelihood-in fact a higher livelihood than that of our workmen to-day, and in addition the all-important possibility of intellectual freedom which in many cases was soon realised." 1

Mr. Unwin, whose book on $T$ he Gilds and Companies of London gives so clear an account of their value in the growth of the life of the town, has estimated their force as a great social lever with equal emphasis: "The political liberty of Western Europe has been secured by the building up of a system of voluntary organisations, strong enough to control the State, and yet flexible enough to be constantly re-moulded by the free forces of change. It is hardly too much to say that the foundations of this system were laid in the gild. It was in the gild that voluntary association first came into a permanent relation with political power."2

With these few preliminary thoughts in mind I will pass on to give some account of the past achievements of this great spirit of associative effort.

\section{ORIGIN OF GILDS}

The student is faced with the most conflicting theories which have been presented by those who have made a close study of Gilds, and who have honestly and patiently

1 Foundations of the Nineteentb Century. H. S. Chamberlain. Vol. II, p. 348.

2 The Gilds and Companies of London. G. Unwin. p. 14. 
striven to unearth the truth from the archives of the past. Controversy has arisen over many points; for instance, with regard to the genealogy of the various associations. Were the Gilds the lineal descendants of the Roman Collegia? Can the Trade Unions trace their direct origin to the Craft Gilds? Were the early Fraternities formed for the maintenance of peace, mentioned in the Statutes of Ine, Gilds in the real sense at all ? It is not necessary, neither would it be possible for me to attempt to adjudicate on the rival theories in this most difficult field of research. Questions of this nature, though of intense interest to the historian, need not detain us. For my purpose it is sufficient to emphasise that Gilds, Trade Unions, Friendly Societies and the Co-operative Movement, are all different manifestations of the same spirit, are all responses to specific demands for special forms of combination.

Two motives have always existed to induce men to unite for special purposes. The individually weak have sought the strength of numbers, as in the old fable of the bundle of sticks-L'union fait la force. Secondly, there has been a mutual sympathy drawing men together who were engaged in the same form of labour or craft, inducing them to unite for social purposes. Societies have, therefore, been developed in various shapes and forms to meet these demands in Ancient Rome, Greece, Turkey, Italy, France, Germany, India and China.

Whether our Anglo-Saxon Gilds therefore can be proved to be of Roman origin or no, a study of the Collegia and the Gild system reveals many striking resemblances. The aims of both were dual; they were both religious and social in character. The two elements were indeed so closely interwoven in the lives of the people that 
this was necessarily the case. The Roman association was presided over by a master and senators : stewards and treasurers were among its officers : it raised contributions from its members : and possessed that essential feature of the Gild and Friendly Societies-a common box. It possessed its priests and temple, just as the Gild was connected with the Church, and had both its priest and its chauntries. It owned a hall where its business was transacted, and where its feasts were held. It granted maintenance to its poorer members, and publicly buried its dead with ceremony, insisting on the attendance of all members at the funeral. A Roman society is known to have fallen into financial straits at Pannonia, when the membership dropped and subscriptions ceased. A public notice was issued that if " anyone should have died," he was not to deem himself a member of the society or as having any claim for burial. ${ }^{1}$ A curious recognition indeed of posthumous existence!

Arrangements for burial are usually placed first and foremost in associative effort, and the instinct to show respect to the bodies of the departed was strongly marked in Roman days. So great was the care shown, that we find in the rules of a Gild formed in the reign of Hadrian, in A.D. I33, at Lanuvium in Italy, that if the body of a slave member was wrongfully withheld from burial by his master or mistress, it became the duty of the Gild to bury his effigy with funeral honours. In the records of this same society, which were inscribed upon the walls of the temple of Antinous, there were rules to regulate the conduct of members, of which we find frequent echoes in the more modern societies: "If

1 Friendly Societies and their Congeners. Economic Review. J. M. Ludlow. 1896 . 
anyone change his seat at table through ill-feeling he shall be fined four sesterces; if he speak insultingly to another member, or cause a disturbance, he shall be fined twelve sesterces; but if he speak insultingly or disrespectfully to the President during a feast, the fine shall be twenty sesterces."

Another object of the Roman Collegia was, according to Cicero, the avoidance of lawsuits between its members. This feature appears again and again in the ordinances of our English Gilds, and is also characteristic of the Gilds of modern China. When St. Paul wrote: "Does a brother go to law with brother," he was probably appealing to the members of the early Church not to fall below the standard of the heathen societies by which they were surrounded. ${ }^{1}$ It is evident that the value of this peacemaking spirit must have been very great. According to Mommsen, eight of the Roman Gilds of craftsmen dated from the days of King Numa, and were therefore of very great antiquity. These were the Fluteblowers, Coppersmiths, Fullers, Potters, Goldsmiths, Carpenters, Dyers and Shoemakers. It appears from a passage in Plutarch that these associations received royal sanction. Numa we are told " divided the people into trades . . . ordering them to have brotherhoods, festivals and meetings, and indicating the worship they had to accomplish before the gods, according to the dignity of each trade."

The information respecting these early Roman manifestations of the Spirit of Association is limited, but it appears that their general features had much in common with those of the British Societies.

In Ancient Greece the right to combine for special purposes seems to have existed since the days of Solon,

1 Two Thousand $Y_{\text {ears }}$ of Gild Life. J. M. Lambert. p. 26. 
and Fraternities are known to have been performing good work in the second and third centuries B.C. They were numerous in Rhodes, the Piraeus, and the islands of the Archipelago. Their resemblance to the English mediæval Gilds is even closer than in the case of the Roman Collegia. The members paid contributions to a common fund, aided one another in distress, celebrated feasts, kept religious observances, and provided for funerals. Disorderly conduct was punishable by fine, and members who did not keep up their payments were excluded, unless they could show good cause for their omission by reason of poverty or sickness. As with the English Gilds, we find that women were habitually admitted as members.

It appears, therefore, that sufficient is known to us of the Societies which existed in both Greece and Rome, to prove that whether the Anglo-Saxon Gilds were actually imitations of Roman institutions or not, the claim which has been made for England, as being the birthplace of Gilds, can be no longer maintained.

\section{ENGLISH GILDS}

The Gilds of England may be most conveniently dealt with in three groups, and in the chronological order in which they made their appearance. First the Frith or Peace Gilds, secondly the Social and Religious Gilds, and thirdly the Trade Gilds which may be again sub-divided as Merchant and Craft Gilds. It must however be clearly understood that one form of association did not rise phœnix-like from the ashes of its predecessor. The various kinds of Gild lived on side by side, each fresh development being an expression of Gild life to meet a new need, an answer to a demand made by a change in methods of employment, in the 


\section{FLEXIBILITY OF THE GILD SYSTEM II}

conditions of life, or in economic circumstances. Each form of association in its turn was of value to meet the special requirements which had evoked it, and each bore its share in the evolution of our religious, social and industrial history. For instance, the Social and Religious Gilds were indicating the growth of a fuller civilisation and heightened aspirations, while the Frith Gilds were still avenging wrongs and keeping the peace. The Merchant Gilds were uniting to protect growing trade in terests, whilst the entirely Religious and Social Gilds were still beautifying the towns with their pageantry, and meeting in solemn service for prayer. The Craft Gilds marked the advent of a new middle-class, the growth of a more democratic spirit, and the increasing division of labour into a large number of "mysteries" and "crafts," while the Merchant Gilds were still, among their other activities, contending for monopolies and trying to protect their members from foreign competition.

One of the merits of the Gild System was this flexibility, due doubtless in large degree to its mainly voluntary character. Though tradition and the pride of ancient custom were there as restraining forces, there was a freedom to meet new conditions by fresh regulations, and an enlargement of the social area from which members were drawn. It was this elasticity which made the Gild organisation so great a power through so many centuries, and gave it a continuous existence, unbroken, though not unaltered, by the great changes which occurred in the government of Church and State.

It is necessary to point out that with many of the Gilds it is difficult to decide from their ordinances in to which group they should be placed. Many of them were neither entirely social and religious nor entirely Trade 
Gilds in character ; it is often, therefore, impossible to draw a sharp line of demarcation, and to estimate which element preponderated. This is more especially the case as there was a certain amount of secrecy in relation to the social or domestic side of Gild life. This is well shown in many of the ordinances, by words such as the following: "Whoever makes known the affairs of the gild, and it is proved by two brethren, shall be put out as perjured, and his example shall be held up to everlasting scorn."1

\section{THE FRITH OR PEACE GILDS.}

Our information about the Gilds of Saxon days is very scanty, and there are in consequence great differences of opinion as to their influence. Of their great antiquity there is no doubt. When the townsmen of Stratford-on-Avon were required to make a return of the ordinances of their Gild to the Government of King Richard II, they replied as to its origin that it "was whereunto the memory of man reacheth not." It is obvious that neither memory nor research will enable us to unveil much that lies hidden respecting the earliest forms of Gild life in Saxon England. Certain facts are, however, definitely known, and to these we will direct our attention.

The meaning of the word Gild is closely connected with the origin of the institution. In Anglo-Saxon the word was spelt gyld, gild or geld, and signified a payment or a compensation. The Frith Gilds were called into being to protect life and property, and were, therefore, in a measure the products of the lawlessness

1 English Gilds. T. Smith. p. 167. 
of the age. They were sworn communities performing some of the functions which later on were undertaken by the State as police duties. The work of punishment, compensation and redress, which had hitherto fallen on a man's own kin, was in this way, in the process of social evolution, taken up by groups of persons larger than the family or the clan. The circle was extending. In the laws of Ine, of about A.D. 690, and of King Alfred of some two hundred years later, associations of this nature were mentioned. It was ordained in the ninth century, under Alfred's Law, that if a man, " kinless of paternal relatives, committed homicide, it became the duty of his gegildan (the members of the fraternity to which he belonged), to pay the wer-gild or compensation due for the offence. Half the fine, in the event of the dead man having no relatives, was payable to the king, and half to his gegildan. The Statutes of the London Frith Gilds were committed to writing as early as the reign of Athelstan in about A.D. 925. From these "Judicia Civitas Londonix" (the Dooms of the City of London), it may be gleaned that the Gilds were no longer content with merely attempting to keep the peace, but were undertaking further activities. The members, we know, assembled at monthly banquets, where the business of the societies was discussed, the remains of the meal being given to feed the poor. The religious element was already present. On the death of a member it was ordered that each "gegilda" should contribute a "gesuful" loaf for the benefit of the departed soul, and sing, or procure to be sung, fifty psalms within thirty days.

In connection with the ancient London Gilds the Cnighten Gild must be mentioned. The "cnight" 
was apparently a man-at-arms or armed retainer. Very little can be stated with any certainty with respect to this Gild, but the romantic if fabulous story of its origin is too interesting to be passed by. It is related by Stow that in the days of King Edgar (another version says King Canute) "there were thirteen knights or soldiers, well-beloved to the king and realm, for service by them done, which requested to have a certain portion of land on the east part of the city, left desolate and forsaken by the inhabitants, by reason of too much servitude. They besought the king to have this land, with the liberty of a guild for ever. The king granted their request, with conditions following: that is, that each of them should victoriously accomplish three combats, one above the ground, one underground, and the third in the water; and after this, at a certain day in East Smithfield, they should run with spears against all comers ; all which was gloriously performed, and the same day the king named it Knighten Guild." 1 The Gild which was thus incorporated continued in existence until the year I $125 .^{2}$

There is reason to suppose that sworn communities for the protection of right and the preservation of liberty were very numerous in Saxon times, not only in England, but throughout Northern Europe. One of the most interesting was that founded at Roskild by King Canute, after the conversion of the Scandinavian peoples to Christianity. Its object was the suppression of piracy by the Vikings : "The Gild-brethren seem to have been as true a set of heroes as ever banded together. They lived soberly, endured all manner of hardships, had as few

1 A Survey of London. John Stow (ed. by W. J. Thoms). p. 46.

2 The Gilds and Companies of London. George Unwin. p. 25. 
followers as possible, took the sacrament before going on board; if they took a pirated ship they gave its owners one-eighth of the booty, if in want and they had to borrow money of the towns, they gave back one half of the booty: all Christians found on board the captured vessels they set at liberty, clothed them and sent them home. They were entirely successful, and secured no fewer than 800 Vikings' ships."1

Kemble, in his History of the Anglo-Saxons, gives the Statute of a Gild at Grantabryac or Cambridge which is to a great extent a Frith Gild. It provided against theft from its members, and also, under penalty of fines, for help to be given to any brother who was in straits and required the assistance of his brethren. If a member was robbed, the whole Gild had to help him to obtain compensation from the offender. A leading principle of the society, to which every member was bound by oath, was always to support him who had right on his side; but so strong was the corporate sense that suffering with the wrong-doer was one of the duties of membership: "If one mis-do, let all bear it ; let all share the same lot." This represents an ethical standard which no subsequent forms of associative effort have in this respect surpassed. It stands out clearly, even from the small amount of evidence which can be obtained, that the Frith Gilds of our forefathers had, before their disappearance, served a useful purpose. They had done something towards building up a more stable condition of society, and had initiated and fostered a sense of brotherhood which was destined to have a profound effect upon our national life.

1 Gilds and Friendly Societies. J. M. Ludlow. Contemporary Review, April, 1873 . 


\section{CHAPTER II}

\section{RELIGIOUS AND SOCIAL GILDS}

A considerable amount of information about English Religious and Social Gilds has been preserved as the result of an inquiry, ordered by Parliament, in the reign of Richard II, in the year 1388 . It was then ordained that two Writs should be sent to every Sheriff in England, commanding him to make public proclamation throughout the shire; the first called upon "the Masters and Wardens of all Gilds and Brotherhoods," to send up to the King's Council in Chancery returns of all details as to the foundations, government, liberties, ordinances, usages, and property, whether in land, goods or chattels of their Gilds. The second Writ called upon the "Masters and Wardens and Overlookers of all the Mysteries and Crafts" to send up copies and charters of their letters patent where they had any, upon pain of annulment and forfeiture of the said letters and charters.

To these returns, which were made during the winter of 1388-9, Mr. Toulmin Smith directed months of patient study, and his work gave the first impetus to scholars to direct their attention to the subject. His translations of these ordinances, from which all references in this chapter, save where otherwise stated, are obtained, were made mainly from the original records, which had 
lain neglected and apparently forgotten in the Public Record Office. Many of them were decayed by time and gnawed by rats. The returns, of which over five hundred are known to be extant, were made in English, Latin, or in Old Law French. They varied greatly with regard to wealth of detail. Some of them merely set forth the minimum amount of information required by the Writs on the barest strips of parchment, and were only a few inches in size; whereas other returns were made in so generous a spirit as to fully cover several large skins.

The valuable transcriptions and translations made by Mr. Toulmin Smith from some of these documents were published under the auspices of the early English Text Society, with a brilliant preliminary Essay on $T$ be History and Development of Gilds by Dr. Brentano, in the year I870. Though some of the theories advanced by Dr. Brentano have been overthrown by more recent historians, notably by Dr. Gross in his Gild Merchant, the vivid picture which he presented of this previously unexplored side of English social life, did much to stimulate further inquiry.

The Social and Religious Gilds made their appearance in England before the Norman Conquest, and their humane and civilising influence can be traced from very early times. Dr. Brentano gives an account of a Gild of undisputed date, which was founded and richly endowed by Orcy, a friend of King Canute, at Abbotsbury in honour of God and of St. Peter. Its statutes reveal very interesting and characteristic features. The objects were both philanthropic and religious. It provided for the nursing of infirm brethren, and for gifts of alms and of bread "well boulted and thoroughly baked," to be made to the poor on the occasion of the annual feast, which was 
celebrated on St. Peter's Day. Provision was also made for religious observances, the burial of the dead, and for yearly worship in honour of the patron saint. ${ }^{1}$

It is interesting to note that the Esnaifs, or Gilds of modern Constantinople, share this feature of recognition of a patron saint with our early English Gilds. The same aims, methods and characteristics are thus seen to recur ceaselessly in associative effort, in spite of the everrevolving wheel of Time. Eve is the presiding genius of the washerwomen, Adam of the tailors, Elijah of the furriers, Noah of the carpenters, and Abel is the patron of the herdsmen in the Turkish capital to-day, just as St. Michael, St. Leonard, St. Fabian, St. Botolph, St. Christopher and St. Nicholas watched over associations of English men and women hundreds of years ago.

At Exeter there was a famous Gild, the rules of which survive, and in this case both the religious and social customs were still further developed. The Gild brethren assembled three times a year to pray for their living and their dead. They had a common meal after each service of prayer and commemoration, to which members brought contributions of malt and honey. The principle of mutual assurance was definitely established. On the death of a brother each member of the Fraternity contributed fivepence, "and at a house-burning each man one penny," to help repair the loss. We find also, the earliest hint, though the object was a different one, of "trampmoney," which was to become so important a feature in Trade Union benefit work, in the monetary contributions made by the brethren of the Exeter Gild, for those departing on a journey.

Let us now pass on to a general consideration of the 1 English Gilds. T. Smith. p. lxv. 
chief characteristics which marked the life and activity of the Religious and Social Gilds in England. The ordinances and records present us with much diversity in detail which adds greatly to their interest; but at the same time certain features are common to many of them, and from these we are able to form a very clear idea of the prevailing customs and of the organisation of these associations.

With regard to membership, we find that with rare exceptions they admitted " bretheren and sisteren" of all ranks. With the advance of time, as the Fraternities grew in wealth and prosperity, even kings and princes joined them. Henry IV and Henry VI are both known to have been members of the Gild of the Trinity at Coventry. The ordinance, therefore, of the Gild of St. Michael on the Hill, which Mr. Toulmin Smith describes as a sort of cross between the Social Gild and the Craft Gild, with a clause proclaiming its exclusive nature, is a curious exception to the rule: "And whereas this gild was founded by folks of common and middling rank, it is ordained that no one of the rank of mayor or bailiff shall become a brother of the gild, unless he is found to be of humble, good, and honest conversation, and is admitted by the choice and common consent of the brotherhood and sisteren of the gild. And none such shall meddle in any matter, unless specially summoned; nor shall such a one take on himself any office in the gild ... And no one shall have any claim to office in this gild on account of the honour and dignity of his personal rank." 1 A remarkable declaration of sturdy independence for the year 1350 !

The members were bound by solemn oath to keep the rules of their society, being then received lovingly by

1 p. 179. 
their brethren with a kiss of peace. With regard to the members being bound by oath it must be noted that the opposition to sworn communities was far greater on the continent than in England. Consequently the task of mutual association in our country was an easier one. In France many attempts were made to suppress sworn confederacies, and heavy penalties, including noseslitting and other mutilations, were levied by the laws of Charlemagne on those venturing to combine. The early growth and development, therefore, of our English societies was remarkably peaceful, and the fact that this was so re-acted on the nature of these Fraternities. Though they may not have been wholly guiltless of political intentions, they were free to work in a lawabiding spirit for the social and religious welfare of their members. That the membership in some cases was very large is shown by an interesting calculation made by $\mathrm{Mr}$. Toulmin Smith, who computed that no fewer than I4,850 brothers and sisters belonged to the Gild of the Corpus Christi at York.

Priests were sometimes admitted to the Gilds in a private capacity, but more generally they were merely paid servants, and responsible for the due performance of the religious services attended by the society.

The priests also formed societies of their own which were known as the Gilds of Kalendars, so called from the fact that their meetings were held on the Kalends of each month. The number of members in these Gilds was sometimes limited to the number of the twelve apostles, and sometimes to twenty-four. In later days the priests admitted laymen to these bodies, and the activities of the Gilds of Kalendars were very similar to those of the other Religious Gilds. ${ }^{1}$ The Gild brothers and sisters made 1 p. Ixxxix. 
payments to the societies to which they belonged, and in this respect almost infinite variety in the regulations is to be found. The sum was sometimes paid in money, sometimes in kind, and we find that in the latter case a contribution of barley and of wax for the altar candles, was very general. In some cases the subscription was paid yearly, in others monthly or even weekly, and the moneys were carefully stored away in the "common pyx," or box.

The executives of the Gilds were variously constituted, but the organisation seems to have been generally speaking efficient, and the stewards, aldermen, and other officers were required to render accounts of the expenditure and possessions of the Fraternities. It appears from the inventories still in existence that the possessions in some cases were considerable. They consisted, in addition to their funds, of church ornaments, of the furniture of the Gild-houses, of the properties for plays and pageants, and in some few cases, in the villages and country towns, of lands. Some societies, it is recorded, invested in cows or oxen, hiring them out for fixed sums by the year.

As we have seen in the case of the ancient Gilds of Exeter and Abbotsbury, there were periodical days of meeting. These were usually the days appointed for the commemoration of the special saints to which the Gilds were dedicated. On these occasions business was transacted, accounts were considered, and new members were admitted. The meetings were named "morningspeeches" (morgen-spac), from Anglo-Saxon times. "Morgen" signified both "morning" and "morrow." "The origin of the term would seem to be that the meeting was held either in the morning of the same day or on the morning (the morrow) of the day after that on 
which the Gild held its feast and accompanying ceremonies." 1 The feasts were held in the Gild-house, or if the society did not possess a building, at the different houses of the members in succession.

The standard of conduct demanded of the brethren was high, and many regulations appear in the ordinances as to the peaceable and orderly behaviour to be observed at both the festivals and meetings. Fines were levied for misbehaviour, and we find for instance, as a rule of the ancient Gild of the Holy Cross of Stratford-upon-Avon : "If any brother or sister shall, after the bell has sounded, quarrel, or stir up a quarrel, he shall pay a halfpenny."2 Members were expected to shun company and businesses that were unworthy ${ }^{3}$ and also it was enjoined that the company of the excommunicated should be shunned by all.

It was frequently insisted that membership was conditional on good character. The wardens of the Gild of the Lord's Prayer at York were instructed to question the applicant as to whether he had "bent his mind to live rightly," before admitting him to the brotherhood." We find that the evil-doer was definitely repudiated by his society: "No brother shall be so bold as to do wrong to anyone, thinking that the gild shall back him up. If he does, he shall be put out of the gild for ever.",

The rules also in many instances provided that the quarrels of members should be submitted to arbitration, before either party might seek legal redress. Innumerable disputes doubtless owed their settlement to the mediation of the officers of the Gilds, and herein we find perhaps the most valuable of all the social services rendered by the Fraternities to their members.

The really law-abiding character of these associations
1 p. xxxiii.
2 p. 217.
${ }^{3}$ p. 137.
4 p. 139.
${ }^{5}$ p. 146. 
is also shown by regulations, that no ordinances were to be made "against the common law," "the liberties of the town "were to be upheld, and members who rebelled against the law of the land or against canon law were to be punished by expulsion.

\section{THE RELIGIOUS ACTIVITIES OF THE GILD}

The ordinances, upon which the following accounts of the religious and social activities of these societies are based, include those in which these elements are found to preponderate. Several of them share the characteristic features common to both the Religious and the Trade Gilds, and are a cross between the two-they lie on the border line. Only those, however, have been used to provide illustrations for this chapter, in which the majority of the regulations relate purely to religious and social rather than to craft matters.

What, then, were the contributions of Gild life to the social and religious welfare of their members and of the community generally?

We have first to note that the religious and social activities and ceremonies of the Gild were closely interwoven. The "General-Day," or "Gild-day," marked as it was by feasting and business, was no merely secular commemoration. On that day " the bretheren and sisteren," clad in livery or hoods, in token of their corporate unity, and sometimes adorned with garlands of oakleaves or flowers, assembled at the church. They bore lighted candles in their hands, which they presented before the altar, and there offered Requiem masses for the souls of the departed. Perhaps the most prominent feature in their work was the provision for the Christian burial of 


\section{RELIGIOUS AND SOCIAL GILDS}

their members. The most careful regulations on this subject appear again and again in the ordinances.

The arrangements made by the Gild of the Holy Trinity and St. Leonard of Lancaster are among the most elaborate, and provided for the repetition of Paternosters and Hail Marys, and also for a mass to be said, and for wax lights and torches to be used on the day of the burial. If any members died without the city within a space of twenty miles, twelve members were to "wend and seek the body at the cost of the gild," and so it was to be borne back to a last resting place in its native town.

It appears to have been customaryto keep night-watches with the dead, and the Ordinance of the Gild of the Palmers of Ludlow is especially interesting with regard to this, it being enjoined that the watchers should not "call up ghosts," nor make mockeries, and further that no woman unless of the household of the dead should keep such a night-watch. ${ }^{1}$

The rules of the Gild of St. Benedict of Lincoln may be quoted as giving a typical account of the rites and customs observed on the death of a Gild-brother: "When any brother or sister dies within the city, the Graceman and Wardens shall go to the body, and the Dean shall bring four wax lights, which shall burn there until the service is done; and on the morrow, when the body is buried, the Graceman shall offer a penny, and each Warden a halfpenny, of the goods of the gild. Besides this, every brother and sister shall give a halfpenny to buy bread, to be given to the poor for the soul of the dead, while the priest celebrates mass. Whoever fails in this offering shall, next day, pay one penny, or a pound of wax at the next morn-speech. When any brother or sister

1 p. 194. 
dies outside the city, on pilgrimage or otherwise, and the death is made surely known to the brethren, they shall do, for his soul's sake, the same as they would have done had he died in the city, and this in his own parish." 1

This allusion to members dying on pilgrimage is of special interest. Several of the returns conjure up a picture of the Gild-pilgrim starting forth with the contributions of his Fraternity in his wallet, and accompanied some little distance on his road by his brethren, to wish him God-speed in his arduous undertaking: "If any brother or sister wishes to go on pilgrimage to the Holy Land, every brother and sister shall give him one penny; if to St. James's or to Rome, each shall give a halfpenny, unless he likes to give more; and the pilgrim shall be accompanied outside the gates of the city. And when he returns and has let his fellows know it, they shall go out and meet him, and go with him to the mother church."2

In connection with the rules relating to burial and the commemoration of the dead, some mention must be made of the Chauntries which played an important part in the Gild life of the Middle Ages. The Chauntries were " singing-services," or special masses, which were sung at the altars of the parish churches, for the souls of their founders, who were frequently members of the Fraternities. As the custom of endowing these Chauntries became widely extended, the sums of money, which were originally only sufficient to provide for a priest, greatly increased, and enough money was often left by the testators to erect special chapels, wherein the sacred offices were performed. In this way it arose that the extension and re-building of churches owed much to the beneficent bequests of members of the Gilds. Stow, in his Survey of

$$
{ }^{1} \text { p. } 173 .{ }^{2} \text { p. } 172 .
$$




\section{RELIGIOUS AND SOCIAL GILDS}

London, makes constant reference to this custom, and shows that many of the city churches benefited in this way.

Perhaps the most picturesque of the Gild activities was the provision of plays and pageants, which were originally of a sacred character. Dr. Brentano points out that societies for the representation of religious plays were common in European countries in the Middle Ages, and that the performance depicting the Life of Our Lord, given every tenth year at Oberammergau, has its origin in this ancient custom. We may also trace the origin of the Lord Mayor's Show in London to the days when many a town in England was enlivened by an annual pageant.

The Gild of the Lord's Prayer at York is a well-known example of an association the primary object of which was to perpetuate a religious performance. It appears that the procession was no mere dumb show, but was a spoken play performed as the players passed through the streets of the town, escorted by Gild-brothers clad in the livery of their order. It seems that this Gild was founded in response to a request that the play "setting forth the goodness of the Lord's Prayer," once played in the city of York, should be kept up in times to come, for the " health and amendment of souls." 1 York has also a Gild of the Corpus Christi, founded in A.D. 1408. The primary object of this brotherhood was to provide that the Blessed Sacrament should be borne in a shrine in stately procession through the streets of the city, accompanied by " the priests in their surplices, and the masters carrying white wands."

The ordinance of the Gild of St. Elene at Beverley also gives an account of a procession which took place annually to commemorate with simple imagery the finding

1 p. 137. 
of the Holy Cross. On these occasions it is related that : " a fair youth, the fairest they can find, is picked out, and is clad as a queen, like to St. Elene. And an old man goes before this youth carrying a cross, and another old man carrying a shovel, in token of the finding of the Holy Cross." 1

One very practical service was rendered to the Church by the Gilds-the brethren frequently undertook and carried out the necessary structural repairs. The Gild of Pampesworth, Cambridgeshire, affords a curious example of this custom. Some buckets of barley were given "to put out to increase, for the use and repair of the church in the said town, which is in poor condition and partly decayed; and as of necessity in a short time the top (tort) of this, called the 'roof,' must be made anew, and it cannot be done without the aid of the Gild, they pray for God that their goods be not disturbed." "The Gild of Swafham Bulkek, in Cambridgeshire, undertook not only the structural repairs of the church, but the renovation of vestments, books, and other ornaments."2

There were also Gilds of Church Bell Ringers, that of Westminster being notably of very ancient date. Its history may be traced from a document in the Public Record Office to "the time of the Blessed Edward, King and Confessor."

A Fraternity at Stamford commemorated the anniversary of the death of "good-doers" by the ringing of a special peal of bells. There is also much to show that the brethren and sisters delighted to be accompanied by "much music" as they wended their way in procession to the parish churches, and some Gilds were formed with the express object of practising such music. ${ }^{3}$ These, then,

1 p. $148 .{ }^{2}$ p. xxxvii. ${ }^{3}$ p. 294. 
were a few of the more important services rendered by these Gilds to religion. A realisation that "vain is the gathering of the faithful without some work of kindliness is done," induced the Fraternities to evolve schemes of charity and mutual assistance which must also be briefly described.

\section{MUTUAL AID}

If the services of the Gilds in fostering a religious spirit in our forefathers were great, we find also that their provision for mutual charity was both beneficial to the members, and destined to have a far-reaching effect on legislation. Before the inauguration of the Poor Law in Elizabeth's reign, there were but few sources of relief open to the poor. Casual and often misapplied charity, monastic doles, which fostered rather than relieved pauperism, the crumbs which fell from the rich man's table, and an inadequate number of hospitals for the sick, the orphans, and the aged, were utterly unable to cope with the distress which swept over England during visitations of plague and famine, and while the Feudal System was passing away. Thousands literally died of starvation. Such a condition was incompatible with the ideals of an advancing civilisation.

The Gilds were the first lay associations to evolve and apply the methods and principles of mutual help; and in their acceptance of at least some degree of responsibility for the welfare of distressed members we find the germ of an ever-widening sense of responsibility which was finally to be accepted by the State.

There is little doubt that there was a definite connection between the Gild customs and the action of the 
municipal rulers with regard to the poor, and that it was partially through the example of the Gilds, and the association of the municipal rulers with these Fraternities, that the towns first began to take an active part in the administration of poor relief. The methods adopted by the Government of Elizabeth in formulating a scheme of State relief were not, as is sometimes supposed, invented by the Commons at Westminster. They were merely the embodiment by Statute, for the whole country, of experiments which had been made by the municipal governors in various parts of England for dealing with the difficult problems of vagrancy and distress. There can, therefore, be little hesitation in stating that the relief methods of the Gilds were pioneer efforts wherein we find not only the first mutual voluntary help which was destined to make so gigantic a growth in England, but also an example which in some measure influenced, even if indirectly, the legislation which ultimately built up the Poor Law.

What, then, were the measures taken by the Fraternities to relieve suffering and distress ? It must be confessed that for a time at least inadequate and meagre doles were the methods most generally adopted. The thought of the benefit accruing to the souls of the benefactors was a very prominent one in this as in all forms of medixval charity.

The Gilds, it must be pointed out, were not solely mutual aid societies at all. The difference between the principle actuating their system of relieving needy members and that of the Friendly Societies is a fundamental one. The dole given by the Gild brethren was a charity which was maintained doubtless as long as funds remained in the common-box, whereas the claim of the 
Friendly Society member on his association is for a definite sum to be paid under specific conditions, to which he has an absolute right.

Mr. Unwin, in an interesting account of the benefits awarded by the London Gilds, points out that the financial responsibility of the Fraternities was confined to those who were actually needy amongst their aged and sick members. $\mathrm{He}$ is of opinion that the Gilds must at times have proved insolvent, more especially as the conditions of relief were often somewhat loosely specified. He quotes in illustration the return made by the Fraternity of St. Giles in reply to the Writ of King Richard II. It was therein stated that $10 \frac{1}{2} \mathrm{~d}$. a week was paid to poor members as long as there were means to do so, but at the moment of making the return, there was but $15 \frac{1}{2} \mathrm{~d}$. in the common-box. ${ }^{1}$ The prospects of members receiving continuous relief in such a case were obviously negligible. It appears also that the brethren had usually to contribute for seven years before becoming eligible for benefits. These early efforts, however, must not be underrated. Their value lay in the fact that by these means the foundation stone of a scheme of mutual help and assurance was laid upon which a mighty superstructure was to be built. Also, doubtless, many of the Gild brothers and sisters were tided over a period of illness and misfortune by timely help from the funds of their Fraternity.

The return of the St. John the Baptist Gild of Hull may be given as an illustration of the relief regulations of many societies : "If it should happen that any man or woman of the said Gild shall be infirm, bowed, blind, deaf, dumb, maimed, languishing with perpetual or temporary infirmity, either in youth or age, so that they have not

1 The Gilds and Companies of London. George Unwin. p. 121. 
wherewith to live: it is ordained and granted each of them for charity, and for the souls of those in the Gild, of our own goods and chattels as long as they continue, each brother and sister by the officer for the time being, weekly one halfpenny of silver." It was further enacted that on St. Martin's Day (the saint it will be remembered of the halved cloak), five shillings of silver should be given to the pensioner to buy a garment. ${ }^{1}$

Among the causes of distress frequently mentioned in the ordinances as qualifying members for relief is leprosy, which affords testimony of the terrible prevalence of that disease in England during the Middle Ages.

The regulations carefully provided in many cases that help should only be given to a member when he had not brought disaster upon himself by his own misdeeds. Good conduct on the part of brethren who were in receipt of relief was also insisted upon: "If it happens that any brother or sister has been robbed, or has fallen into poverty, then, so long as he bears himself well and rightly towards the bretheren and sisteren of the gild, they shall find him in food and clothing and what else he needs." 2 Brethren cast into prison through no fault of their own were objects of solicitous care. They were visited by their fellow-members, and every effort was made to secure their speedy liberation. "If it befall that any of the bretheren, by some hapless chance, and not through his own folly, is cast into prison, all his bretheren are bound to do what they can to get him freed and to defend him." ${ }^{3}$

The tender consideration shown for the feelings of the recipient of the charity of the Gild is

1 Two Thousand Years of Gild Life. J. M. Lambert. P. I13-114.

2 p. $219 .{ }^{3}$ p. 169. 
illustrated in the same ordinance: "If any of them fall into poverty, they shall go, singly, on given days, to the houses of the bretheren, where each shall be courteously received, and there shall be given to him, as if he were master of the house, whatever he wants of meat, drink, and clothing, and he shall have a halfpenny like those who are sick; and then he shall go home in the name of the Lord." 1 Loans from the common-box were in some cases awarded to distressed members, to enable them to continue or resume their calling. When " in better case" the debtor was expected to repay the loan, but in one instance we find the rule that if he failed his society in this matter, the debt was to be repaid to the common-box from the sum which was collected after his death, "for his soul's sake." 2 The Gild of the Smiths of Chesterfield made the business-like declaration that it had the first claim on the goods of any brother dying intestate who owed money to the society. ${ }^{3}$ Modern legislation incorporated this same principle when it was laid down, under Sir George Rose's Act, that the first charge on the estate of the officers of Friendly Societies was any debt or liability to their society.

Several of the Fraternities, among which may be mentioned that of Sts. Fabian and Sebastian of Aldersgate, made wise provision that the young should be helped to get work, and the Gild of the Palmers of Ludlow, with remarkable generosity, provided means for any good girl of the Gild of marriageable age, to enable her to go into a religious house, or to marry in accordance with her wishes.

The charitable efforts of the Gilds were by no means confined exclusively to their own members. Much was done for the poor in a more or less systematic way. The

${ }^{1}$ p. $169 .{ }^{2}$ p. $181 . \quad{ }^{3}$ p. 170. 
remains of the feasts were frequently distributed among the needy, and a Norfolk Fraternity made provision for the annual distribution of a certain amount of corn and barley among the indigent. ${ }^{1}$

Education, too, in some cases was brought within the scope of Gild activities. The return of the Gild of the Palmers at Ludlow, made by the Commissioners of Henry VIII at the time of the Reformation, shows that the Society had established a school and maintained a "Scolemaster of Gramer" from its funds. The Fraternity of the Kalendars of Bristol, in a truly missionary spirit, founded a "school for Jews and other strangers to be brought up and instructed inChristianity.""

As time passed it was realised that more systematic help should be afforded to the distressed poor than by merely supplying needful food and periodical sums of money. The members of the Gild of the Blessed Mary of Chesterfield made it a duty to find " a house of religion" where their leprous, sick, or aged poor should be cared for during their last years. Such homes were doubtless hard to find in many parts of the country, and so it arose that the Fraternities began in a tentative way to find lodgings for their destitute members. They first merely hired a cottage or two, but the custom of housing the poor was extended until many of the Religious Gilds possessed their own almshouses, and so afforded a most necessary form of relief. The Gild of the Holy Cross of Birmingham, which is especially interesting, as having contributed to the commonweal by repairing the great stone bridges of the town and divers foul and dangerous highways, may be given as an instance of a society supporting "poore men and women" in almshouses. ${ }^{3}$
1 p. xxxvii.
2 p. 288.
3 p. 249. 
Such, then, were some of the works of faith and charity inaugurated and sustained by the brethren of the Religious Gilds. It is impossible to study the regulations and usages of these Fraternities without being profoundly impressed by the truly Christian spirit which inspired them. It stands beyond dispute that the manner in which they bore their testimony to a living faith, and performed active work for the Church with which they were connected, served to foster a spirit of piety in our forefathers. Peace, Justice, Charity, Mercy, Brotherlykindness, were the virtues to which the members of the Gild were bound by oath. Even though human weakness may have caused achievement to lag behind intention, the influence of the ideal set before the brethren must have borne abundant fruit in a heightened standard of life.

\section{THE REFORMATION}

The continuity of this expression of Gild life was doomed to be rudely broken. From the days of King Canute until the middle of the sixteenth century this form of associative effort had endured, unchecked by State interference. During the Reformation, however, ruthless hands were laid on the possessions and lands of the Fraternities, and a blow was struck at the Religious Gilds of both priests and laity, from which they did not recover. Many of them indeed were so entirely ruined that they passed utterly into oblivion, and their very existence has been completely forgotten. How wide and general the Gild movement was when the Reformation began in England may be shown by the following estimate : "In many of the parishes of Somerset, which we have no reason to suppose differed in this respect from 
parishes elsewhere, there were from six to a dozen Gilds or Fraternities, each for the purpose of a separate ' devotion,' with its own 'store,' and audits, and feast-days. And in the single county of Norfolk, a list, which is manifestly imperfect, returns as many as 909 Gilds." 1

It is probable that Sir Frederick Eden's conjecture is correct, and that in some cases these societies, "even after the confiscation of their lands at the dissolution, continued their stated meetings in the common-room or hall, for the purposes either of charity or conviviality." 2 But even so they were shorn of their most characteristic features, and there can be little doubt that much which was valuable was swept away. The Religious Gilds were judged to have been "founded on superstition," and were therefore almost completely annihilated.

This is no place in which to discuss the pros and cons of the Reformation, and its effects upon the Church of England, nor to estimate the consequent gains and losses to our national and religious life. We are merely concerned in the present volume with its effect upon all forms of Gild life. In our study in a subsequent chapter of its influence upon the Gild system generally, we shall find that there has been some over-statement as to its destructive effects. The Craft Gilds were altered, their work was modified, but they were not destroyed. If the annihilation of the Religious Gilds was catastrophic, the history of the passing away of the Trade Gilds, both Merchant and Craft, is that of a peaceful euthanasia, and it is to misconceive facts to describe them as victims of violence.

The first blow was struck at the Fraternities in 1545 by

1 Economic History. W. J. Ashley. Part II, P.. 138.

2 State of the Poor. Sir F. Eden. Vol. I, chap. iii. 
the 37 Henry VIII, c. 4, and it is evident that all the institutions aimed at in this Act were mainly of a religious character. It was alleged that many of the possessions of the Colleges, Free-chapels, Chauntries, Hospitals, Fraternities, Brotherhoods, and Gilds, had of late been misapplied, that there had been instances of individual misappropriation, and that foundations which had been created " to the intent that alms to the poor people and other good, virtuous, and charitable deeds might be done," had been misused. It was, therefore, enacted that the King, who was resolved that these endowments should for the future be devoted to "more godly and virtuous purposes," should be empowered to appoint Commissioners, who should have authority to seize on his behalf the lands and possessions of all such foundations, specified in the Act.

Professor Ashley, who has dealt at some length with the effect of the Reformation upon the Craft Gilds, maintains that in the proceedings which followed the passing of the Act, there is " no sign that the Government intended to use its powers to make a clean sweep of all the religious foundations." He considers that the Commissioners who were sent to report upon the Chauntries and the strictly Religious Gilds performed the task in as accurate a manner as the circumstances permitted, and in no unsympathetic spirit for the charitable work of the bodies which they visited. In several instances, indeed, they pointed out the utility of the Gild chapels, in enabling worshippers who lived at a distance from their parish churches to attend divine service conveniently. ${ }^{1}$

During the minority of Edward VI, when it has been well said that "avarice and rapacity stalked abroad,"

1 Economic History. W. J. Ashley. Part II, pp. 143, 144. 
further legislation was passed, directed at the Religious Gilds.

The Act of 1547 (I Edward VI, c. I4), denounced the dogma of purgatory, and declared that masses for the departed had provoked superstition, and had kept the people ignorant of the true doctrine of salvation. It was, therefore, argued that the revenues hitherto devoted to such masses would be more profitably used in the relief of poverty and distress, and in furthering educational work by erecting grammar schools and assisting the universities. All Colleges, Free-chapels and Chauntries were therefore declared to have passed in to the possession of the King. It was further ordained that all sums of money which the Gilds or Fraternities (amongst other specified bodies), had devoted to " the finding, maintenance or sustentation of any priest, or of any anniversary, or obit or lamp, light or other such thing," were to pass to the Crown. Provision was made by the same Act that in those cases in which perpetual allowances had been made to the poor, from the funds of these societies, the regular payments were to be continued. This concession was likewise to apply to the execution of public works, such as the maintenance of piers and seawalls, roads and bridges. Lands were to be assigned to grammar schools or preachers, where such provision had been made by the Gilds in the deeds of endowment. The Commissioners were also empowered to devote some of the revenues, acquired under the Act, to increase the number of clergy in understaffed parishes. ${ }^{1}$

It is obvious that the interpretation and administration of legislation such as this must depend upon the spirit of those entrusted with the work of carrying it into

${ }^{1}$ Economic History. W. J. Ashley. Part II, p. 146. 
execution. How far the revenues thus arbitrarily confiscated were devoted to the purposes indicated by the Act, and how far they were used to satisfy the greed and rapacity of court favourites, is one which it is impossible for me to determine. Professor Ashley considers that " the question has never yet been impartially investigated," and is of opinion that "a much larger portion of the revenue did actually go in the end to public purposes than the language of many modern writers would lead us to suppose." 1

It must, however, be remembered that public morality in the reign of Edward VI was at its lowest ebb ; Northumberland and Somerset, whose powers were almost unlimited, were noted for their avarice. Liberty was not bought without price. The changes which were taking place in religious opinion, the loosening of much which had tied and bound men's consciences, and the weakening of many habits of outward religious observance, all brought their inevitable dangers; and it appears to me that when the final verdict of history is passed on the Reformation, it will be found impossible to justify much of the treatment which was accorded to the Religious Gilds. Be this as it may, it can be stated without hesitation that all Gilds which were mainly religious in character were brought most ingeniously within the scope of the confiscatory Acts of Henry VIII and Edward VI. To whatever purposes the revenues of these Fraternities were ultimately devoted, the great majority of the Religious Gilds were as a fact ruthlessly driven out of existence at the Reformation.

1 Economic History. W. J. Ashley. Part II, p. 145. 


\section{CHAPTER III}

\section{TRADE GILDS}

In approaching the study of the English Trade Gilds, it is well to divest our minds of the economic theories which are applicable to the social life of our own time. Any attempt to estimate rightly the value of the manifestations of associative effort of past centuries is doomed to failure if we insist on gazing into the past with eyes blinded by modern views and prejudices, and so rendered incapable of sympathetic vision.

We shall find linked with a great deal that is admirable, in the history both of the Merchant and the Craft Gilds, much which violates a modern standard of liberty, and much which appears selfish and narrow in the restrictions which their rules imposed. The methods and theories of the past must, however, be judged in relation to contemporary conditions, and not in relation to those of the present time. With regard to this point the suggestive theory has been advanced that: "History seems to be proving that no great institution has been without its use for a time, and its relative justification. Similarly, it is beginning to appear that no great conception, no great body of doctrines which really influenced society for a long period, was without a certain truth and value, having regard to contemporary circumstances." 1 The Gild system influenced English municipal, social and indus-

1 Economic History. W. J. Ashley. Part I, p. xi. 
trial life, to an extraordinary extent for several centuries. It held whole sections of the community in its grip, and it ruled the conditions of sale and production in certain trades and crafts with an iron rod. The will of the individual craftsman was thereby subordinated to the collective will of his society. The execution of every kind of work was regulated with closest detail in the interests of both producers and consumers. Defensive regulations were made to check competition not only against the foreigner, but against the traders of the neighbouring towns.

The study of the now obsolete Gild system has affected two classes of minds in different ways. On the one hand, we find those who bewail present conditions and seriously desire the restoration of the Gild organisation; on the other hand, there are those who maintain that the Trade Gilds even during their lifetime sapped prosperity and checked enterprise. It appears to me, however, that it would prove as impracticable to attempt to revive Gild life in its entirety in England, as to try to raise labour by the methods adopted by the Pharaohs in building the Pyramids. Autres temps, autres mours. The past cannot be recalled. Though we may regret the loss of much that was admirable, the true explanation of the disappearance of the Trade Gilds seems to be that they perished when the particular means taken by them to supply human needs were no longer required. As their birth and growth were a response to a demand arising from the circumstances of our early industrial history, their disappearance was certainly a sure sign of their unfitness to survive.

Mr. Unwin pertinently remarks, in relation to the fact that the Gilds of Western Europe are now dead whilst the Gilds of the East still live on, that the former have 
performed the most useful of their functions; they have helped to build up a social structure by which they have been superseded. ${ }^{1}$ The Gilds of India at the present time are regulating competition, upholding the interests of their own societies, settling disputes, appointing holidays, punishing their members by fine and acting as mutual assurance societies, in a manner strangely reminiscent of the customs of the associations of medirval England. They are, in fact, performing the functions required by the industrial and social conditions of India to-day; and we may safely prophesy that when the period of social evolution is passed for which they are peculiarly adapted, the Gild system of the East will give place to fresh forms of associative effort more suited to the requirements of other stages of civilisation.

If I cannot support the theory that it would be either useful or possible to again endow the Trade Gilds of England with the breath of life, neither do I find myself in agreement with those who deny their utility in the past in the growth of our national and commercial life. There is indeed much to show that these associations of our forefathers were the outcome of a shrewd instinct as to the best means by which to take advantage of the rapidly changing economic conditions, and to develop successfully the new and growing industries. When the restrictions of the Trade Gilds proved to be harmful, industry emancipated itself from their shackles, and, their part performed, they disappeared.

RISE OF THE MERCHANT GILDS

Modern investigation has, up to the present time, found no traces of Merchant Gilds which existed in

1 Gilds and Companies of London. George Unwin. p. 4. 
England in Anglo-Saxon days, and there is every reason to think that they first appeared as the result of the great changes wrought by the Norman Conquest. The causes which contributed to produce them are not hard to find.

The close union between England and the great Northern duchy of France stimulated commerce, and the fact that the lands on either side of the Channel were under one ruler doubtless added to the security of the traders passing to and fro. Before the Conquest there appears to have been no considerable commercial class in England. A certain amount of internal trade was doubtless carried on in the eighty small towns which are known to have existed when the Normans landed on our coasts. London, Winchester, Bristol, Norwich, York and Lincoln, which were by far the largest and the most important of the towns in the eleventh century, had still very small populations. It is estimated that at the time of the Norman invasion these towns contained only some seven or eight thousand inhabitants. ${ }^{1}$ The people of Great Britain dwelt mainly in small, self-sufficient and somewhat isolated communities. They made provision for their own requirements by working the land, and by the exercise of a few simple crafts. Dr. Cunningham, in his valuable history of English industrial life, has pointed out that there is little or no evidence that much had been done in the introduction of manufactures before the Conquest, and he infers from Domesday that no industry was conducted on any large scale. ${ }^{2}$

The size of the trade with foreign countries has been variously estimated by historians, but it seems certain that the imports consisted almost entirely of luxuries,

1 Economic History. W. J. Ashley. Part I, p. 68.

2 The Growth of English Industry and Commerce. W. Cunningham. p. 84 . 
such as purple-cloth, costly embroideries, silks, gems, gold, ivory and brass, which could only have been acquired by the wealthy, and in which the large majority of the population had neither interest nor share. That the crossing of the seas by a trader was an event of importance in Anglo-Saxon days is shown by the fact that the merchant who had distinguished himself by doing so three times was honoured by the conferment of higher civic rank, and was made a thane. The internal state of the country was so disordered that the perils by land must have been even greater than those by sea, and the new security for traders, under the more peaceful conditions which prevailed during the powerful rule of the Norman kings, did much to pave the way for an increased industrial activity. A Saxon chronicler, writing of the reign of William the Conqueror, said : "Among other things is not to be forgotten the good peace that he made in the land. It was such that a man . . . might go over the kingdom unhurt with his bosom full of gold." " "All ports and roads," William of Poitiers stated, "he ordered to be open to merchants and no injury to be done them."

Coincident with the marked expansion of English trade dating from the closing years of the eleventh century, we may mention the extraordinary commercial activity which was to be found at this time throughout Europe generally. This impetus without doubt reacted favourably on the trade of our island: "The merchant cities of Italy were attaining to power; those of Spain were forming a barrier against the Moslem; the communes of France were beginning to free themselves from the extortions of turbulent barons; the burghs of Scot-

1 Anglo-Saxon Cbronicle, A.D. $\operatorname{10S}_{7}$ (ed. Thorpe). II, p. 189 . 
land were attaining their highest prosperity; and there are traces of the associations which in time developed into the Hanseatic League, and formed a great network of commercial stations all over Europe." 1 Trade and industry were thus, owing to the new sense of security, making an extraordinary growth; and the Merchant Gilds were called into being about twenty years after William the Conqueror landed on our shores, as protective unions to foster the interests of the increasing number of traders. The primary object of these Merchant Gilds was to guard industry from encroachment and competition. Whether they were merely a fresh expression of the Gild idea which, as we have seen, had already been developed in England to a considerable extent in the Frith and Religious Gilds, or whether they were transported from Norman soil, we have no means of deciding. It is however known that Trade Gilds were performing active services in the towns of France before the Conquest, and it is extremely probable that Englishmen learnt their first lessons in this special form of combination from the Norman merchants who thronged the markets of England after peace was restored. ${ }^{2}$ From the time that the first English Merchant Gild, of which we have any knowledge, was formed at Canterbury, during the primacy of Anselm in 1093, this form of association spread from town to town. So rapid, indeed, was this diffusion that before the close of the twelfth century, every considerable town in England, with the exception of London and the Cinque Ports, may be presumed to have possessed this form of society. ${ }^{3}$

1 The Growth of Englisb Industry. W. Cunningham. p. I19.

2 The Gild Merchant. C. Gross. Vol. I, pp. 4, 5 .

3 Economic History. W. J. Ashley. Part 1, p. 72. 
CONSTITUTION OF THE MERCHANT GILDS

The membership of the Merchant Gilds consisted, broadly speaking, of all who traded. Though merchants from neighbouring towns, the local monasteries and the lords of the manor, were in some cases admitted to the Gild privileges, membership was in the main confined to those who held land within the town boundaries.

The word "merchant" had a wider significance in the eleventh and twelfth centuries than it possesses at the present time, and in this fact we find the clue to a good deal of the misconception which has arisen concerning the relations which existed between the Merchant and the Craft Gilds. The term embraced all who bought and sold, and so included the small shopkeepers and many of the handicraftsmen. The latter were, indeed, freely admitted to the Merchant Gilds, and in all probability constituted during the twelfth, thirteenth and fourteenth centuries, the majority of the members.

Dr. Gross, whose scholarly book is a mine of information on all matters concerning the Merchant Gilds, points out that: "The line of demarcation between merchant and craftsman was not yet sharply defined. Every master craftsman was regarded as a merchant, for he bought his raw materials, and sold the products of his handiwork in his shop or at his stall, just as some coopers, shoe-makers, bakers and other tradesmen still do at the present day." 1 The theory, therefore, which has received wide credence, that it was the tyranny of the Merchant Gilds which drove the craftsmen to form societies of their own, wherewith to resist oppression, cannot, as far as England is concerned, be supported by the evidence. This point will be further dealt with in a succeeding chapter.

1 The Gild Merchant. C. Gross. Vol. I, p. 107. 
As in the case of the Religious Fraternities, the members of the Merchant Gilds paid contributions, or initiation fees, from which, however, the eldest sons or heirs of gildsmen were sometimes exempt. The similarity is again apparent in that the new member took an oath of fidelity to his society, swearing to obey its laws, to observe secrecy with regard to its councils, and to uphold its privileges. $^{1}$

The affairs of the Gild were controlled by officials who were generally elected by the brethren. The meetings were presided over by an alderman, or in some cases by two aldermen. There were assistants, usually two or four in number, who were known as wardens or échevins. The executive generally consisted of an inner council of twelve or twenty-four members. ${ }^{2}$ Among a number of other officers mentioned in the ordinances were: chaplains, cup-bearers, tasters, doorkeepers, bailiffs, sergeants and provosts, from which it may be inferred that in some cases the organisation of these societies was very elaborate. The business of the Merchant Gilds was transacted at periodical meetings or "morning speeches," which were followed by social intercourse and merrymaking. Feasting was always a prominent feature in the annual Gild celebrations, and interesting descriptions survive of the manner in which the brethren conducted their repasts. At Great Yarmouth, the Gild of the Holy Trinity, years after its trade activities had ceased, held its annual feast in a hall which was "richly hanged and adorned with cloth of Arras Tapestry and other costly furniture, not sparing any dainty fare which might be had for money. At which feast all private quarrels and

1 The Gild Mercbant. C. Gross. Vol. I, p. 29.

2 Economic History. W. J. Ashley. Part I, p. 72. 
emulations were heard and ended, to the glory of God and mutual love amongst neighbours ... therefore the better to prevent all such unkindnesses, was this feast held." An account of the food at this said Gild festival, held in 1564, certainly suggests that the repasts were sumptuous: "Sunday Dynner: The furste course; capon, pyggys, lambe, costard. Sunday Soper: Good brothe with boyled mete, rostyd mutton, capon, lambe, tarte. Monday Dynner: Frometye, rostyd byffe, green gese, lamb. Note, that six persons to every mese, two grene gese to every mese, and a capon to a mese." 1

\section{FUNCTIONS OF THE MERCHANT GILDS}

The main object of the Merchant Gilds was, as has been already intimated, to protect commercial interests. Men were thus united for the first time in England for trade purposes. When these societies came into being industry was in its childhood and without organisation, trade was dependent on individual enterprise; and the Spirit of Association drew men together in groups, with bonds of steel, to regulate and maintain their common interests. The measures taken were in the first instance directed towards securing the monopoly of trade, not only against the "foreigner," but also against those who were not free of the Gild in the town itself. It must first be noted that this word "foreigner" was used in a comprehensive sense to describe any nonburgess, and the merchants of Winchester regarded the traders of Salisbury as foreigners, and legislated against them accordingly. Traders from other lands were denied the privileges of the gildsmen, but not mainly for the

1 History of Great rarmouth, H. Mauslip. 
reason that they were aliens, but because they were not burgesses of the towns to which they came. ${ }^{1}$

The regulations for excluding foreigners from trading privileges were as a rule only directed to securing the monopoly of the permanent trade of a town. Their effect was counteracted, in some degree, by the number of fairs-" great carnivals of barter"-which were held all over the country. To these fairs the merchant strangers could and did come, not only from all parts of the kingdom, but from abroad. For instance, it is recorded of the great herring fair at Yarmouth, which lasted for thirty days, that it was visited by merchants from Italy, Flanders, France and Germany. ${ }^{2}$ The fairs which were held in Southampton, Winchester, and many other towns were largely attended in the same way. It appears, indeed, from the ordinances of the Merchant Gild of Southampton that the foreigners must have attempted to take undue advantage of the latitude allowed them with respect to trading at the fairs, for it was provided that they should not remain within the borough for the purpose of selling their foods for more than forty days.

Many and various were the regulations which were enforced to prevent the non-gildsmen from encroaching on the privileges of Gild brethren. In illustration of these protective measures some of the rules drawn up at Reading, probably during the fourteenth century, may be quoted: "No foreigners shall bring tanned leather to sell into the town of Reading at any time of the year, except only during the fairs; and if anyone does otherwise, let his goods be seized by the hand of the stewards,

1 Economic History. W. J. Ashley. Part I, p. 108.

2 Two Thousand $Y_{\text {ears }}$ of Gild Life. J. M. Lambert, p. 88. 
and he shall be at their mercy; and when he shall have satisfied them, he shall have his goods again."

"Also, no foreign fishmonger who brings fish to the market to sell, shall cut up his fish to sell, except with the permission of the stewards or bailiffs ; and no foreigner can have license to do this, if any gildsman have any fish to sell."

"Also, no stranger shall bring herrings to the market to sell on any day of the week excepting only on one market day; and if he wishes to stay in the town and sell his fish in the market a second day, he must sell two herrings more than he did the day before, or he must go away, and who does otherwise shall be at the mercy of the stewards." 1

At Southampton there were drastic enactments, and it was forbidden to all but gildsmen to buy "honey, suet, salt herring, nor any kind of oil, nor mill-stones, nor fresh leather, nor any kind of fresh skins; nor keep a wine-tavern, nor sell cloth by retail, except on market and fair day; nor keep more than five quarters of corn in his granary to sell by retail, if he is not a gildsman; and if anyone shall do it and be found guilty all shall be forfeited to the King.",

The Statutes of the Gild of Berwick-upon-Tweed ordained, amongst a number of other rules, that: in cases where the buyer was misled by false top samples, amends were to be made: the price of mutton was fixed throughout the year: butchers were confined to their own calling and were forbidden to speculate in wool or hides : no one was permitted to possess more than two pairs of mill-stones: and, perhaps quaintest of all the

1 The Gild Merchant. C. Gross. Vol. I, pp. 45, 46.

2 Ibid. Vol. 1, p. 47. 
trade restrictions, we find that : "Whoever buys a lot of herrings shall share them at cost price with the neighbours present at the buying. Anyone not present and wanting some, shall pay to the buyer twelvepence for profit." 1

If the regulations for protecting trade from nongildsmen were stringent, those which were drawn up by the officers to control the members within the societies were no less severe. The feeling that the submission of the individual member was for the common interest of the whole association breathes through the statutes and ordinances of the Merchant Gilds. The ideal aimed at was, that all "should be as members having one head, one in counsel, one body, strong and friendly." Good behaviour both at the feasts and in the transaction of business was frequently enjoined. An ordinance of the Gild of the Holy Trinity provided that : "None of our brethren shall come into the Gild before the alderman and his brethren capped, or hooded, or barefooted, or in any rude or rustick manner, and if he does he shall pay 4d. for alms."

Fair dealing and a high standard in the quality of the goods offered for sale were often insisted upon. "Regrating," or speculative buying in order to make a profit on re-sale, was strictly forbidden. Punishments were meted out with no unsparing hand to those who broke their oath and did not conform to the laws which bound them. Thompson has furnished us with an account of the proceedings of the Merchant Gild of Leicester, at one of its meetings in A.D. 1254, which gives some idea of the very real control exercised at the " morrow speeches" over erring members: "Roger Alditch was charged

1 English Gilds. Toulmin Smith. p. 345. 
with offending the laws of the Gild, having made a blanket in one part of which was a good woof, but elsewhere in many places weak stuff. He also caused a piece of weak and inferior vermilion cloth to be attached to a good piece of the same kind of cloth. It was adjudged that he should pay a fine of $6 \mathrm{~s}$. $8 \mathrm{~d}$. and, if he should commit another offence against the Gild, he should be expelled. William of Ayleston was accused of having sold the wool of the men of Hinckley and Coventry, against the rule of the Gild. He was fined 6os." Three years later "the whole Gild in full assembly" was called upon to deal with a brawl between two of its members, and it was decided that: "Hugh at the Solar having struck Roger Alditch in the market of St. Botolph, and the latter having struck the former, both were fined a tun of beer by the community of the Gild." 1

CHARITABLE AND RELIGIOUS OFFICES OF THE MERCHANT GILDS

Though charitable and religious work did not take so prominent a place among the activities of the Merchant Gilds, as in those of the Fraternities whose aims were purely social and religious, yet the ordinances reveal that these aspects of Gild work were by no means neglected. We are indeed aware that in some instances, even when the work of trade regulation on the part of the Merchant Gilds had ceased, they still lived on to perform these functions which had originally been regarded as merely secondary. In Winchester, for instance, it was ordained in 1656, long after the Merchant Gild had lost its power as an active trade body, that "every person and persons

1 History of Leicester. James Thompson. 
within this citty being free of the Gild of Merchants shall on every Lord's Day and days of humiliation and thanksgiving, go with the Mayor to church in their gowns."

The subjoined account, quoted by Dr. Gross from Richard's History of Lynn, gives some conception of the religious and social work executed by a Merchant Gild. From the possessions of the Trinity Gild of Lynn " many alms-deeds and works of charity were yearly given, which one year with another are computed at $€ 30$, viz., towards the said guild, to the blind, lame and other distressed persons, to poor clerks keeping school, and poor religious houses, as well of men as women, to the lepers in and about Lenne, and to the maintaining of several acqueducts for the use of the said town: all the goods and chattels aforesaid are in the hands of the said alderman, and of four men of the said guild called skivins, who yearly distribute the said goods as aforesaid." This Gild also maintained thirteen chaplains to pray for "the peace and welfare of the kingdom, for the souls of the aldermen and brethren and of all faithful deceased." This record of services rendered in the interests of the community generally may be taken as a typical example of the valuable work which many of the Merchant Gilds performed. It must be remembered that in all probability the ordinances and statutes do but scant justice to thisthe more private side-of Gild work. There is, however, evidence that a considerable amount of relief was given by these Gilds, not only to their own distressed brethren but to the sick and poor.

To pursue this subject further would be merely to repeat much that has been said in the last chapter, with regard to the social and charitable work of the Religious 


\section{TRADE GILDS AND THE MUNICIPALITY 53}

Gilds. It suffices to point out that the spirit of mutual help was still vigorously manifested by the Merchant Gilds, and that many of the same general features were present. Prisoners were visited by officers of the societies, whose best efforts were directed to obtain their release; sick members were visited and wine and food were sent to cheer them from the feasts; daughters, in some instances, received dowries for marriage, or to enable them to enter convents; and brethren were buried by the gildsmen with solemn rites and ceremonies.

THE MERCHANT GILDS AND THE MUNICIPAL CONSTITUTION

One other question of great importance relating to the work of the Merchant Gilds demands our attention. What share did these bodies take in the government of the towns? This question is no easy one to answer, as much which relates to the actual position of the Trade Gilds in municipal government still remains vague and obscure. Historians have differed profoundly on this point. Some writers have asserted that they were merely private associations of merchants bearing no share in the administration of the town, whereas others have maintained that the "Gilda Mercatoria" and the body which governed the affairs of the borough were one and the same thing.

A great difficulty in arriving at the truth arises from the fact that conclusions drawn from a careful study of the civic connection of one Gild may be overthrown by all that may be discovered about another. It is apparent that in the early stages of local government the powers exercised by the Gilds in administering the affairs of the towns of England varied much, at one and the same time. 
The point is an important and interesting one for those who would attempt to gauge the achievements of voluntary associative effort, for there is undisputed proof that these bodies gradually came to bear some share of the burden of public administration. Though the extent to which this was the case has not yet in all probability been finally estimated, the theory that these bands of merchants worked permanently merely as private bodies in pursuit of their own interests, has been entirely overthrown.

Dr. Gross, after careful examination of this question, has divided the history of the Merchant Gilds into three stages, and has thrown light on much that was previously obscure.

During the first stage the Merchant Gild was in his opinion : " a wholly new and spontaneous growth, it was doubtless at first merely a private society, unconnected with the town government, having for its object the protection of its members, the tradesmen of the borough, and the maintenance of the newly invigorated trade interests." 1 The Gild and the borough were therefore originally quite distinct.

The second stage, Dr. Gross considers, was reached during the twelfth century, when the Merchant Gild gradually became a recognised part of the town constitution. This development appears to have resulted naturally from the fact that the most influential burgesses shared not only in the counsels of the Gild but were also members of the municipal body. The mercantile interests and those which concerned the prosperity of the borough to a large extent coincided, and so gradually an "unconscious extension of the unity" of the two bodies took

1 The Gild Merchant. C. Gross. Vol. I, p. 159. 
place. It arose therefore quite naturally that the town authorities increasingly delegated some of their functions, especially those relating to trade interests (the preservation of monopolies and so forth), to the "merchants." 1 It was therefore as official bodies and as a part of the administrative municipal machinery that they laid down many trade regulations of the nature already indicated in this chapter.

The Merchant Gilds not only legislated on behalf of the town on trade matters, but interesting examples may be found of their taking upon themselves the duties of health authorities.

The ordinances of the Gild of Berwick-upon-Tweed affords an instance of a trade society undertaking this most necessary work. "No leper shall come within the gates of the borough; and if one gets in by chance, the sergeant shall put him out at once. If one wilfully forces his way in, his clothes shall be taken off him and burnt, and he shall be turned out naked. For we have already taken care that a proper place for lepers shall be kept up outside the town, and that alms shall be given to them."

"No one shall lay upon the banks of the Tweed, within the marks there set up, any dung or dust-heaps, so as to be a nuisance to those living near. Whoever does so, shall pay eight shillings." 2

The ancient boroughs were by no means entirely neglectful of sanitary laws, and many rules may be found such as these: "No butcher or cook shall throw into the streets any filth or other matter, whereby the town or the street may become more dirty, filthy or corrupt." Offenders against such regulations were duly fined.

1 The Gild Merchant. C. Gross. Vol. I, pp. 98, 159.

2 English Gilds. Toulmin Smith. P. 34 I. 
During this second stage it has, therefore, been placed beyond dispute that the Merchant Gilds had become an integral part of the administrative machinery of the municipalities. For a period of some two hundred years these associations were thus taking an important share in the evolution of town government.

The third and final stage is marked by the gradual disappearance of the Merchant Gilds, until they ultimately ceased to exist as distinct organisations. Many totally disappeared, others were absorbed into the civic body, and so, losing their own individuality, became identical with it. This third period will be more closely examined in connection with the rise of the Craft Gilds. To sum up, we recognise in the Merchant Gilds combinations which originally were purely voluntary in character, but which in the process of growth became of such importance that they were used as instruments of public administration. When from various causes they had ceased to be of service as separate entities, those that survived were merged into the municipal bodies.

The value of the direct influence of these primarily voluntary societies in the growth of our town life and government was obviously very considerable. We may also infer that the indirect influence was far-reaching. The trade societies were schools of citizenship, in which men attempted to govern bodies of individuals for the good of all the members, and in which experiments were made which courted both failure and success. It may be safely assumed that much which had grown spontaneously, and been proved of value in the voluntary associations, was absorbed into the municipal government. The extraordinary development which took place in England and in many parts of Europe during the Middle Ages, 
owed much to the organised efforts of the Trade Gilds. Mr. Unwin, indeed, maintains, in writing of the building up of the town, which in its turn helped to build up the free self-governing nation, that the chief factor was: " the spirit of voluntary association, and that spirit found its most typical and widespread embodiment in the various forms of the Gild." 


\section{CHAPTER IV}

\section{TRADE GILDS (continued)}

\section{RISE OF THE CRAFT GILDS, AND DECLINE OF THE MERCHANT GILDS}

The causes which led to the disappearance of the Merchant Gilds, and those which produced the Craft Gilds, must be considered in connection with one another. The first appearance of the latter form of trade society was made during the reign of Henry I, when Gilds of weavers were formed in London and Oxford. The weavers of Winchester, Lincoln, York and Nottingham followed suit, and formed associations, during the next reign.

Dr. Cunningham favours the theory that the Craft Gilds were of Norman origin. He regards them as an importation from Rouen rather than of native growth. The evidence of language supports this supposition, for it seems unlikely that societies of indigenous growth would have been so generally known by the Romance name of mestier or mystery. ${ }^{1}$ From the thirteenth century the word Gild ceases to appear prominently in English industrial history, and the associations for which the

1 Growth of English Industry and Commerce. W. Cunningham. Pp. 131, 132. 
name originally stood were more generally known as "Crafts," or "Misteries."

The rise of the Craft Gilds, which were destined to become a great social force, took place at the time when men first made one specific form of industry the occupation of their lives. Throughout Western Europe, in Flanders, Brabant, France and the Rhenish towns, the sequence of events was the same, and the weavers were pioneers in the work of co-operation. The explanation of this circumstance is that the manufacture of articles of clothing satisfied an elementary and universal requirement, and the weaver's occupation was the first to assume a position of sufficient importance for men to devote their whole lives to it.

The birth of the Craft Gilds, therefore, marks a new period in the history of English labour. As the Merchant Gilds resulted mainly from a new impulse to trade, so the Gilds of craftsmen arose in response to the demands of a new class of handicraftsmen which was wholly engaged in industry. The merchants, who took advantage of the comparative peace secured by the Conquest to develop trade in our island, found the vast majority of the population still engaged in agriculture. The Anglo-Saxons satisfied their few requirements by manufacturing rough articles of clothing and primitive implements; manufacture was merely the by-product of their lives. The peace which had facilitated the growth of trade also gave rise to organised handicrafts, and from the twelfth century onwards we note a growing division of employments, and an increasing distinction between the tiller of the soil and the artisan. Hence it arose that groups of handicraftsmen were to be found, more especially in the towns, engaged in life-long industrial labour. These groups had 
common interests which required protection, and so they formed themselves into Craft Gilds. The new movement spread rapidly. During the thirteenth century craftsmen appear to have united for purposes of mutual aid in all branches of manufacture, and in all towns where industries sprang into existence.

The relations which existed between the Merchant Gilds and the Craft Gilds are difficult to determine. It has been assumed by some writers that the desperate struggle which took place on the continent, especially in the towns of Germany and the Netherlands, with regard to the rival interests of burgesses and handicraftsmen, had its counterpart in England. The fact that much of our early industrial history is veiled in obscurity has led some historians to argue from foreign analogies, and in this case the practice has led to fallacious conclusions. The artisans of Western Europe had undoubtedly a hard fight to obtain the right to combine in Gilds at all, and to secure any share in the government of the towns. But in England the conditions were somewhat different, and there seems to be no evidence to show that a great class struggle, in which democracy bore off the palm of victory, took place in England during the twelfth and thirteenth centuries. During that period the Crafts certainly encroached upon the privileges possessed by the Merchant Gilds, and materials are wanting to show exactly how the change took place. As time progressed, and the craftsmen gained a larger degree of power, they showed themselves to be as tenacious of their newly-won rights and privileges as were the older associations. Rival interests no doubt conflicted and friction resulted, but the processes which led to the weakening of the Merchant Gilds and the • growing power of the Crafts were rather those of gradual 
adjustment than of violence and conflict. The historian Stubbs cautiously maintained that: "The struggles between the patrician burghers of the merchant-guild, and the plebeians of the craft-guilds, which mark the municipal history of Germany, have no exact parallel here." Dr. Gross goes much further, and will in no way accept the theory that in England the societies of handicraftsmen were the outcome of " a revolutionary movement by which the oppressed plebeian craftsmen endeavoured to throw off the yoke of an arrogant, patrician Gild Merchant." 1

It appears, indeed, to have been established that the decline of the Merchant Gilds may be traced more accurately to the irresistible force of developing industry, than to a victory resulting from a struggle between oppressor and oppressed.

It is necessary to dispose of the idea that the new movement towards the organisation of the Crafts was a democratic labour movement at all. The "working classes," using the term in its modern sense, did not arise until the end of the fourteenth century, and did not become an important factor in industrial England until the fifteenth century.

During the period which we are considering the craftsman was both salesman and manufacturer, but he conducted his operations on a very small scale. Capital at first played quite a minor part in production. The artisan who first devoted himself wholly to industry merely required technical skill whereby to secure a small connection with a steady demand for his products and a little money with which to buy tools and to hire a house. ${ }^{2}$

1 The Gild Mercbant. C. Gross. Vol. I, p. 126.

2 Economic History. W. J. Ashley. Part I, p. 93. 
It may be conjectured that, as the demand for manufactured goods increased, the craftsman began to employ others to help him to meet it. At first he probably merely called in the assistance of his own son, or one other man, and so in an entirely natural manner the master-craftsman arose. The line of cleavage existing at the present time between employer and employed was non-existent. The strife between Capital and Labour had not yet begun. The employee had always the confident hope that he would ultimately become a master craftsman himself. If he groaned under a sense of injustice, he realised that his grievances were temporary, and would be righted when he set up on his own account. Purely working-class combinations did not come into being until a number of journeymen were employed, with special interests of their own to guard, and who possessed no prospect of advancement from the ranks of the workmen to those of the employers.

The Craft Gilds during the twelfth and thirteenth centuries were not official civic bodies, exercising delegated powers, as were the Merchant Gilds. They were primarily voluntary associations whose existence was recognised in return for an annual payment made to the Crown. With their recognition as corporate associations they received the monopoly of working and trading in their own particular mystery or craft. ${ }^{1}$ The new bodies remained under the control of the municipal authorities, which had the right to impose ordinances at will upon any Craft. It was also necessary that the town magistrates should sanction the statutes drawn up by the officers of the Craft Gilds to regulate the conditions of labour, sale and production. Jealousy and antagonism doubtless

1 The Gild Merchant. C. Gross. Vol. I, p. 116. 
existed in some degree between the two forms of trade societies when the Craft Gilds first appeared. Professor Ashley, however, points out that a great change took place in the attitude of both the Government and the municipal bodies towards the combinations of craftsmen during the reign of Edward I. The King recognised their potential utility as checks to the power of the governing bodies of the towns, and so exerted his influence on their behalf. The new policy was manifested in the Craft ordinances of the next reign. "The Gild System was no longer merely tolerated; it was fostered and extended, though doubtless primarily for police purposes-to ensure due supervision of the craft, and the punishment of offenders against regulations, through persons chosen by the craft but responsible to the municipal authorities." 1

The rapid increase of these societies, which took place throughout the reign of Edward II, was due doubtless in a measure to this more favourable attitude, but also in still larger degree to the extraordinarily rapid growth of commercial and industrial prosperity. A host of these subsidiary trade Fraternities appeared, and we find such trades as the brace-makers, spurriers, wax-chandlers, pie-makers, scriveners, and farriers forming their own companies. $^{2}$ An interesting indication of the official recognition of their value lies in the fact that they were no longer only spontaneous societies seeking and obtaining sanction, but in many cases the duty of combining was imposed on the members of a trade by the municipal authorities. The masons, for instance, were instructed in I 356 to form a Craft society, "because that their trade has not been regulated in due manner by the government

1 Economic History. W. J. Ashley. Part I, p. 87.

2 Ibid., p. 88. 
of folk of their trade, in such form as other trades are."1

The effect of these numerous associations upon the Merchant Gilds was very marked; every new society of craftsmen sapped the strength and diminished the influence of the older form of Trade Gild.

Men of substance arose amongst the master craftsmen, and they, as the fourteenth century progressed, became wealthy employers of labour, and were also traders on an increasing scale in the commodities which they produced. The result was that the powers of the Merchant Gild, of guarding and controlling the trade of the whole town, were gradually shifted to a number of distinct bodies. When the Craft Gilds attained to their greatest power in the fourteenth and fifteenth centuries the older form of association lost its utility, languished and died a natural death. ${ }^{2}$

The Legislature had also borne a share in forcing the issue. During the wise rule of Edward I it had dealt a death-blow to the power of the Merchant Gilds by the restriction of monopolies. The primary object for which these societies had existed, was, as has already been shown, to secure and maintain trading monopolies, and when this prerogative was taken from them their chief raison d'être disappeared, and so the Merchant Gilds vanished as separate organisations. ${ }^{3}$ For monopolies they had lived, and with the loss of the ability to retain them they perished. Whether or no these powers which they had once held, were, as appears to me, largely justified as protective measures to guard the young and tender shoots of trade, it is certain that the time of their utility

1 Economic History. W. J. Ashley. Part I, p. 88.

2 The Gild Mercbant. C. Gross. Vol. I, pp. I16, 117.

3 Economic History. W. J. Ashley. Part I, p. 84. 
was past, and that their removal was beneficial, not only to trade generally, but to our home industries.

The disappearance of the Merchant Gilds from the time that they were attacked by the Legislature, and overshadowed by the growing strength of the industrial sections of the community, was very rapid. By the end of the fifteenth century, even in the remote districts, where new tendencies made themselves felt but slowly, the greater number had totally vanished. The name long survived in many towns, "but only as a term to describe certain functions of the municipal authorities, especially the admission of apprentices to the freedom of the city."

Some few of the Merchant Gilds were reorganised as religious and social bodies, and so continued to perform some useful work, others degenerated into Gilds which merely recalled their atrophied existence by the observance of festivals and ceremonial. The "Gilda Mercatoria" of Ipswich affords an interesting example of a Gild which changed its character. In the year I325 it was reconstituted as the Gild of Corpus Christi, and it enrolled the priors of the religious houses and the priests of the town among its members. It provided for a yearly procession, when the priests and trade companies marched through the town with banners and pageantry. Feasting, wine, and music characterised the annual celebrations of its semi-official existence. Dr. Gross describes it as having "vegetated on" during the reign of James I, until it ultimately degenerated into merely providing a dinner for the common-council of the town. ${ }^{2}$

In one city only in England has the Merchant Gild lingered on until the present day. At Preston regularly

1 Economic History. W. J. Ashley. Part I, p. 8f.

2 The Gild Merchant. C. Gross. Vol. I, p. 162. 
every twenty years for over three centuries a Merchant Gild has celebrated its existence by ceremonial and festival. It affords an interesting survival of a form of association which had fulfilled its mission, and lost its full powers, as early as the fourteenth century.

\section{MERCHANTS OF THE STAPLE AND MERCHANT}

ADVENTURERS

Some account must be given, though it will necessarily be very brief, of two forms of societies of merchants which, though wholly distinct from the Merchant Gilds, yet formed a part of the Gild System and exercised no inconsiderable influence.

The Merchants of the Staple constituted a fraternity which possessed the monopoly of exporting all the principal raw materials of the kingdom; notably wool, woolfels, leather, tin, and lead. ${ }^{1}$ The exact date of the origin of this Gild is uncertain, but it probably made its appearance during the reign of Edward I; the reason being that just as the fairs were important mediæval methods of promoting the internal trade of the country, so it was considered necessary to establish definite ports to which all staple products were to be brought, and where all imports and exports could be examined. These towns became known as the Staple Ports. Trade was thus forced into definite channels, and the responsibility of guarding and promoting its interests rested with the great Gild known as "The Mayor, Constables, and Fellowship of the Merchants of the Staple of England."

The object was of a two-fold nature; first it gave convenient opportunity for the careful supervision of the

1 The Gild Merchant. C. Gross. Vol. I, p. 140. 
quality of commodities, which was so marked a feature of the whole Gild System, and secondly it was the only method by which the import and export duties could be collected with certainty. The Staple became in the hands of the Sovereign a weapon of both fiscal and diplomatic value, and it was not infrequently moved from one state or town to another from either economic or political considerations.

We may gain some insight into the international value of this Gild from a Statute of the reign of Edward III, which decreed that six persons were to sit as judges in every Staple town, i.e., four aliens, two of Germany and two of Lombardy, and two Englishmen. In all cases in which the strangers made complaints, they were empowered to nominate two of their number to sit with the Mayor of the Staplers, who was instructed to hold a court of law-merchant, with power to punish all offenders. ${ }^{1}$ There can be no doubt that this Gild stimulated trade by providing foreign merchants with courts in which they received not only representation but special protection. The Staple maintained its important position as a standard institution for controlling and regulating English commerce for at least four centuries. The increase of home manufactures and the reduction in the export of wool weakened its power for usefulness, and it received its final coup de grâce as an active organism when the export of wool was prohibited in I660. ${ }^{2}$

The Merchant Adventurers was an entirely spontaneous, voluntary association, and the name is a fair indication of the very spirited enterprises undertaken by

136 Ed. III, c. 7.

The Gild Mercbant. C. Gross. Vol. I, p. 147 
its members and their successors. The date of the origin of the first Company of Merchant Adventurers is likewise veiled in uncertainty. The Society claimed that it had existed from the first half of the thirteenth century, under the name of the Brotherhood of St. Thomas à Becket. The earliest charter, which was granted to it as an organised association, dates from the reign of Edward III. Dr. Gross informs us that the soul of this Society and perhaps its original nucleus was the Mercers' Company of London, and the Mercers' Hall was its headquarters, until the great fire of London in $1665 .{ }^{1}$

This association was described early in the seventeenth century by one John Wheeler as consisting of "wealthie and well-experimented merchants dwelling in diverse great Cities, Maritime Towns, and other parts of the Realme, to wit, London, Yorke, Norwich, Exeter, Ipswitch, Newcastle, Hull, etc." The bond which drew merchants together into this and similar Gilds was the fact that they were engaged in trading in the same ports or markets. These bodies received royal grants of privilege, they bound themselves by rules which in some measure regulated the action of their members, they also acquired property for common use, though the individual members traded in their own stock, and at their own risk. ${ }^{2}$

It is however quite beyond the scope of this book to attempt to follow the career of these important societies, or to trace their subsequent development in to joint-stock companies. The main interest to us, in this attempt to estimate the value of the achievements of voluntary association, lies in the fact that various Companies of Merchant Adventurers were formed during the reign of

1 The Gild Merchant. C. Gross. Vol. I, p. 149.

2 Industrial Organisation, etc. G. Unwin. p. I5 I. 
Queen Elizabeth and her successors, which were destined to exercise a far-reaching influence in shaping the fate of nations. A fresh impulse was given to trade with distant countries by the discoveries of the passage round the Cape of Good Hope, the New World, and the White Sea. Merchant Adventurers, under the inspiration of a widened horizon, formed themselves into Companies to trade with Russia, Turkey, Guinea, Morocco, Spain and America. The genealogy of the constitutions of the American States may be traced back to the Gilds of the Middle Ages. ${ }^{1}$ In the process of evolution the trading Company, which was incorporated under Royal Charter, became a colony; the colony when it threw off its allegiance to the mother country developed into the State. In the East India Company, which originated in the same manner, we find an example without parallel in history, in that our rule in the vast Empire of India is the direct result of the venturesome spirit of traders, who belonged to a society which was based upon an English Gild.

\section{DEVELOPMENT OF THE CRAFT GILDS}

In order to continue our account of the development of the Crafts, we must retrace our steps to the fourteenth century. We have seen that by the close of that century practically every group of men, however small the number which composed it, if engaged in one trade, had either formed itself voluntarily, or been ordered to form itself into a Gild.

It is hard for us, in the midst of our vast and incoherent social mechanism, to realise the extent to which life was

1 The American Commonwealth. James Bryce. Vol. I, pp. 427430. 
regulated under the Gild System, or how close were the bonds with which men were thereby united.

Mr. Lambert, who has succeeded in infusing an atmosphere of reality, and of strong human interest into his account of the Gild life of Hull, gives a description which may well be quoted of the part which it played in mediæval England. "The whole municipal, industrial, and social life of the Middle Ages, if we except the industry of agriculture, moved in the circle of the Gild. Not alone the public, but also the social and private, the moral and municipal, interests of the townsfolk centred therein. They were very largely the Chambers of Commerce, the Friendly Societies, the Trades Unions, the Freemasonry, and in some degree the Joint Stock Companies, of times when the merchant lived in his warehouse, which was also his factory as well as his shop; when the apprentice sat at his master's table for his seven years, somewhat after the fashion of his adopted son; and when to attain the membership of the Gild was to gain a recognised and honourable position in the land. They were no formal organisations for purposes which ended with the hard toil of the working day. The warm blood of the life of the time circulated in them. Their members sat together at the feast, stood by each other's honour in the mart, lived in the same quarter, shared the same purchase, marched side by side in the pageant, acted together in the play, and fought together in the part of the city walls committed to their care."1

From the middle of the fourteenth century, for some two hundred years, the Gilds thus exercised an incalculable influence on the life and habits of the large majority of citizens.

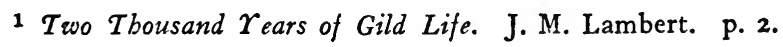


A striking fact with regard to the powers wielded by the Craft Gilds is that the seeds of their degeneracy were sown, when their control was most absolute. The selfishness inherent in human nature asserted itself, and a tendency to unduly restrict competition by checking the number of newcomers to the trades, was one of the ultimate causes of the decline of the Gild System. There is no doubt that the authority, which was obtained in the first instance with the object of securing a high standard of production in the interests of the community, was often abused. A hint as to the danger appeared as early as 1350 , in an ordinance respecting the need of the Wardens' assent before the freedom of the City was granted to an aspirant to a trade. The significant proviso was made that " no person who is proper to be a freeman should through malice be kept out." A century later the nembers of the Crafts frankly avowed that they sought protection from newcomers in order to restrain their competitors.

We shall find in our consideration of the functions performed by the Craft Gilds that this spirit was markedly revealed with regard to the regulation of apprenticeship. Self-interest crept in, and the object of the rules which had primarily been made to ensure that no man should practice a trade without having previously received a good technical training, degenerated into the selfish aim of limiting the number of independent masters. These dangers were inherent in the Gild system, and taking human nature as it is, were probably unavoidable.

Economic causes, such as the growing population, the increased demand, improved methods of production, an influx of labourers to the towns eager to join the ranks of craftsmen, all inevitably led to manufacture on a larger 
scale, and to the genesis of the employer of labour. The differences in natural ability which no reconstruction of society will ever succeed in wiping out, any more than the shuffling of a pack of cards will eliminate the king and knave, brought the more capable craftsmen to the front. This, the purely human factor in the situation, seems to have received too little attention from some historians and economists. The effect of the natural variations in character and capacity in throwing men into different classes has been insufficiently emphasised. An impression is too often given that men are the sport of economic circumstance, and that, formed in one mould, they move in monotonous battalions on the fields of industry in obedience to inexorable laws. Fortuitous circumstances created neither a Napoleon, a James Watt, nor a Robert Owen, and the first "captains of industry" owed as much, we may safely assert, to their own energy and aptitude, as to any coincidence of favourable economic conditions. The men with the greatest skill and business power were masters of opportunity, and naturally led the van when the industrial army was first mobilised. The grading of society thus went irresistibly forward. The masters who possessed the powers and faculties to command success began, as industry expanded, to employ a larger number of subordinates, and motives of ambition and self-interest spurred them to adopt measures to protect themselves from any competition which they felt would be injurious to their trade.

ASSOCIATIONS OF JOURNEYMEN

This increasing differentiation between the status of employer and employed was the cause of the first 
manifestation of the Spirit of Association in a strictly working-class movement.

The journeymen, having arisen in considerable numbers, and many of them having no further hope of attaining to the position of master craftsmen, began to unite to forward their common interests. These combinations of journeymen, which became an integral part of the Gild system, do not seem, in the first instance, to have been formed mainly for purposes of aggression. Dr. Brentano admits that "they exhibit no trace of opposition against the prevailing trade system." In mediæval times the instinct to combine permeated all but the lowest grades of society. When a new class arose it was an entirely natural impulse for it to form societies to promote mutual interests in matters religious, social, and industrial. The subject of these Journeymen's Associations has not as yet been fully investigated by historians. Modern research is, however, tending to prove that though the movement towards association on the part of the journeymen of England was not nearly so widespread as in Germany, such associations were more general than has been hitherto supposed. Professor Ashley, in a valuable account of the movement, concludes that these combinations were to be found in many places, and in connection with various industries, during the fifteenth and sixteenth centuries. $^{1}$ Mr. Unwin, whose recent researches have thrown further light upon the subject, asserts that by the end of the fifteenth century nearly all the London Livery Companies were supplemented by associations of yeomen or journeymen. ${ }^{2}$ Such societies are known to have existed in Coventry, Bristol, Exeter, Hereford, Oxford,

1 Economic History. W. J. Ashley. Part II, p. 108.

2 Gilds and Companies of London. G. Unwin. p. 227. 
Wisbech, Gloucester, Plymouth and Chester, and it may be safely assumed that the examination of local records would result in the discovery of many more examples of such combinations of wage-earners. ${ }^{1}$

It appears from some of the London records that the journeymen were making their influence felt as early as the middle of the fourteenth century by the primitive use of the strike, as a means to bring pressure to bear on their masters, and no little inconvenience was thus caused by the withdrawal of labour during trade disputes.

Some of the Journeymen's Societies were mainly religious Fraternities, and as such fell under the confiscatory Act of Edward VI. Others escaped destruction by being remodelled in subordination to the Livery Company of their craft. ${ }^{2}$ Complaints had been frequently made before the Reformation that the journeymen had formed themselves into Fraternities which were nominally of a religious character, whereas under cover of such societies they had made "covins" or conspiracies to raise wages, and had absented themselves from work on the plea of attending vigils and masses. ${ }^{3}$ In London these organisations met with little favour from the authorities, and when in 1387 three journeymen cordwainers endeavoured to establish a Fraternity, they were committed to Newgate, having confessed that a certain friar preacher had made an agreement with them that he would endeavour to obtain the confirmation of their Fraternity from the Pope. The object of obtaining papal confirmation was that excommunication would be the fate of any attempting to interfere with the well-being of the

1 Industrial Organisation. G. Unwin. p. 5०.

2 Gilds and Companies of London. G. Unwin. p. 230.

3 Economic History. W. J. Ashley. Part II, p. III. 
Fraternity. ${ }^{1}$ A few years later the serving-men or yeomen of the trade of saddlers were charged by their masters with having, " under a certain feigned colour of sanctity, influenced the journeymen among them, and formed covins with the object of raising their wages greatly in excess." It is difficult to gauge to what extent religion served as a cloak under which the journeymen combined with the object of securing higher pay. It is hard enough, in watching the trend of events in our own days, to analyse the motives inspiring corporate action, and in looking back across the centuries there is little hope of estimating fairly the main objects of a movement which was partially religious in character, and respecting which definite information is still limited.

The facts which emerge with certainty are, that these Societies of Journeymen, in their first inception, consisted of wage-earners who associated for both religious and trade purposes. They were impermanent in character, and their efforts to better the conditions of labour were merely spasmodic. When they contended to obtain better terms from the masters, they not infrequently resorted to a strike. An interesting example of the use of this method of industrial warfare occurred in 1538 , when the threatened " picketing" was obviously of a far from peaceful order. The Bishop of Ely reported to Cromwell that twenty-one journeymen shoemakers of Wisbech had assembled on a hill without the town, and sent three of their number to summon all the master shoemakers to meet them, in order to insist upon an advance in their wages, threatening that "there shall none come into the town to serve for that wages within a

1 Riley's Memorials of London. p. 495.

2 Ibid., p. 542. 
twelve month and a day, but we woll have an harme or a legge of hym, except they woll take an othe as we have doon." 1

These associations, which had been for a time entirely independent of the Craft Gilds, underwent considerable changes during the sixteenth and seventeenth centuries. A new class of small masters arose amongst the members, and being known as "yeomen" became a new force in the journeymen's organisations. At the same time most of the associations lost their independence, and became subsidiary bodies within the Gilds. They were partially controlled and supervised by the officers of the Craft Gilds and of the Livery Companies. The Journeymen's Associations, which were thus merged into the organisation of the Gild system, lost their democratic character, and the wage-earners ceased to play a part of any considerable importance in the industrial struggle and the conflict of classes which took place during the sixteenth and seventeenth centuries. How completely the journeymen had lost any real power in the yeomanry organisation is shown by an entry in the Cloth-Workers' YearBook of July 7 th, 1565 . A number of the journeymen, it appears, had resorted to a strike. They are described as "having unlawfully absented themselves from their masters' service. Four of the ringleaders were consequently arrested and committed to ward. They were discharged, "when they had made humble submission," after lying in durance vile for some days.

Some Associations of Journeymen still continued a more independent existence, but the wage-earners did not become a powerful or enduring force in industrial

1 History of Trade Unionism. p. 3. (Cited by S. and B. Webb, from Calendars of State Papers.) 
organisation until the birth of the eighteenth century. The economic forces, which were by then sapping the remaining powers of the Gilds, induced the wage-earners to unite into Trade Unions.

Though no actual connection can be traced between the ephemeral Journeymen's Associations of the fifteenth and sixteenth centuries and the modern industrial combinations of working men, the existence of the earlier societies is a matter of great interest. They were the first organisations which were formed by men who had no hope of rising from the position of journeymen to small mastership, who thus had a life-long motive for desiring to protect and promote both their trade and their class interests. They were, therefore, the distinct prototypes of the Labour Associations, which have exercised so profound an influence on our national life for the last two centuries. 


\section{CHAPTER V}

\section{FUNCTIONS OF THE CRAFT GILDS}

\section{REGULATION OF THE METHODS OF PRODUCTION}

IT will be well, before attempting to outline the history of the Gild System, from the time when it held all industrial England in its sway to its final disappearance at the end of the eighteenth century, to examine in some detail the aims, methods, and achievements of the Craft Gilds.

The first object of these trade societies was to secure a high quality in production. The ordinances of the Gilds teem with rules and regulations directed towards this end. Shoddy work and bad materials had but little opportunity of finding a way into the markets and shops of mediæval England.

When the Gild had received authority from the municipal government to regulate any particular craft, pressure was put upon all those working at the same trade to induce them to enrol themselves as Gild brethren, and so to bring themselves under the control of the association. The object of this, in the early and best days of the Gild System, was not primarily to exclude rivals, but to drive all who were practising one craft within the range of supervision. We find this custom illustrated in the case of the weavers of London, who during the reign of 
Henry I obtained the privilege that: "nobody except by them shall introduce himself, within the City into their mystery, and nobody within Southwark or other places belonging to London, except he be a member of their Gild."

It was with the object of securing adequate inspection of the processes of production that both the legislature and the Gilds insisted that every craftsman should choose his craft and abide by it. An Act of Parliament of ${ }_{13} 6_{3}$ ordained that " artificers and men of mysteries (mestiers, i.e., crafts), shall join the craft he may choose between this time and next Candlemas"; "trespassers" were to be punished by imprisonment for half a year, and by the levy of a fine to be paid to the King. Dyers or weavers were thus forbidden to make cloth, bowyers were prohibited from undertaking the arrow-making which belonged to the fletchers, and shoemakers were not to interfere with the prescribed work of the " cobelers." 1

By these means the Craft Gilds obtained the monopoly of production in the various "mysteries" or crafts. "Wardens" and "Searchers" were appointed to see that materials were good and that work was efficient, and also that irresponsible craftsmen did not present wares for sale. The townsmen naturally supported the movement, realising that the security that their purchases were "truly, substantially and workmanly made," was greatly in their interest.

An interesting description of a progress of the Wardens on their search is given in a record of the Goldsmiths' Company of 1369: "On the nativity of St. John the Baptist, the Wardens went from shop to shop throughout the city and delivered the touch of their Mystery of gold

1 Economic History, W. J. Ashley. Part I, p. 95. 
and silver, charging the Goldsmiths, on the oath which they had taken, not to work silver worse than coin, nor gold worse than the touch of Paris, and to loyally keep the ordinances." 1

A sense of responsibility to the community generally was very strongly marked in many of the Craft ordinances. The Legislature of the period also concerned itself with the most minute details affecting the common welfare. After the Black Death had swept over England in 1348 , wiping out the inhabitants of whole villages in its path, there was a natural tendency on the part of the survivors to take advantage of the scarcity of labour, and to demand an increase in wages. The House of Commons promptly dealt with the workman and the agricultural labourer, and enacted, by means of the famous Statutes of Labourers, that no workman should take more, nor an employer give more, than had been customary before the Plague. The ordinances of the Craft Gilds of the period followed on the same lines, and constantly made similar regulations in the supposed interest of the public, prescribing that nobody "shall take for working in the said trade more than they were wont heretofore." When, a few years later, a tempest caused fearful havoc among the roofs of houses in London, an edict went forth that : "Materials for roofing, and the wages of tilers, shall not be enhanced by reason of the damage done by the late tempest."2

The fundamental principle that all questions of private interest and profit were secondary in importance to the reputation and efficiency of the trade led to all-embracing regulations. With the object of minimising the

${ }_{1}$ Memorials of the Goldsmitbs' Company. Sir W. S. Prideaux. Vol. I, p. .7.

2 English Gilds. T. Smith (Brentano's Essay). p. cxliii. 
opportunities of making defective wares, craftsmen were frequently prohibited from working in garrets or chambers, and were forced to work in the high streets and open shops. Night work was forbidden, not in apprehension of the craftsman, apprentice or journeyman suffering from unduly long hours, but in the fear that the quality of the work might suffer, and rules be broken with impunity, during the hours when the officers of the Gilds would be unlikely to detect the delinquents. This is carefully explained in Riley's Memorials of London Life, from which we find that it was enacted that: "No one of the trade of the Spurriers shall work longer than from the beginning of the day until curfew rung out at the Church of St. Sepulchre without Newgate, by reason that no man can work so neatly by night as by day. And many persons of the said trade who compass how to practise deception in their work, desire to work by night rather than by day; and then they introduce false iron, and iron that has been cracked, for tin, and also they put gilt on false copper, and cracked. And further, many of the said trade are wandering about all day, without working at all at their trade, and then when they have become drunk and frantic, they take to their work to the annoyance of the sick and of all their neighbourhood, as well by reason of the broils that arise between them, and the strange folks that are dwelling among them. And then they blow up their fires so vigorously that their forges begin all at once to blaze, to the great peril of themselves and of all the neighbourhood round."

This passage calls before our minds no picture of a Golden Age, where all worked to the utmost of their power to produce the most perfect results of which they were capable. Obviously in these "good old days" 
many kinds of petty fraud had to be provided against, and the multitude of rules which were made to protect the buyer from dishonesty give us the impression that the standard of commercial morality was not nearly as high as that of the present day. Amongst the tricks which our forefathers apparently practised we may mention: moistening groceries to add to their weight, soldering together broken swords, setting false stones in gold, weighting precious metals with pellets of lead, selling second-hand furs as new, deceiving the buyer by false top-samples, and placing stones in hay or woolsacks to add to the weight.

The minute rules directed to securing the proper execution of work included prohibitions to the Gild members to possess any tools "unless the same were testified to be good and honest." The Gild of Cordwainers of Exeter, and many others, decreed that all defective work should be forfeited.

Measures were taken to protect the customer from having his materials spoiled by indifferent workmanship, and the "whittawers" even directed their brethren to assist any member of the Craft who did not know how to go on with his work in order that the material might not be wasted. The masons were especially scrupulous, and gave the public guarantees of efficiency, "four ancient men of the trade" being required to give security for the proper completion of their work. ${ }^{1}$ With the same object, the bricklayers of Hull insisted upon all bricks or tiles made in town or country being viewed by the "searchers" ; if they proved to be bad they were forfeited, if good the brickmaker had to pay $3 \mathrm{~d}$. per thousand for the privilege of the inspection.

1 English Gilds. T. Smith. (Brentano's Essay.) p. cxxx. 
The bakers were always subject to especially strict rules, and evidently the expedients by which the medixval makers of bread attempted to cheat their fellowtownsmen were many and ingenious. Stow describes the methods which were adopted in London to punish the offenders in this Craft: "In the year Ifor the said prison house was made a cistern for sweet water, conveyed by pipes of lead from Tiborne, and was from thenceforth called the Conduit upon Cornhill. Then was the well planked over, and a strong prison made of timber called a cage, with a pair of stocks therein set upon it . . . On the top of which cage was placed a pillory, for the punishment of bakers offending in the assize of bread, for millers stealing of corn at the mill."

That this punishment must have been a very grizzly one is shown by an editorial footnote stating that engravings trom early drawings of such pillories placed on the top of cages or prisons are shown to have had iron circles or carcans, with holes for the hands and necks of several persons at the same time. ${ }^{1}$ In 1326 members of this trade were detected in having "skilfully and deceitfully made holes in their molding bordes" like mousetraps, through which they put lumps of dough and so defrauded the King's lieges. The summary punishment to which they were condemned was to stand in the pillory with lumps of dough strung round their necks. Another conviction is recorded of one Robert Porter, who was found guilty of putting iron in his loaves, and he was pilloried in the same manner with the signs of his fraud attached to him.?

Instances such as these might be largely multiplied: but sufficient have been given to emphasise one of the

1 Surrey of London. Stow (ed. W. J. Thoms, $1 \&_{42}$ ). F. 72 .

- Two Thousani Years of Gili Life. J. M. Lambert. P. 305. 


\section{FUNCTIONS OF THE CRAFT GILDS}

chief functions of the Craft Gilds. This aspect of their work is admittedly wholly good, and undoubtedly exercised an enormousinfluence in creating and maintaining a high standard of production. It remains to be noticed that the elaborate system of inspection, and the welding of these close ties of association, were greatly simplified by the localisation of industries. Members of one trade usually lived in the same or in adjoining streets. Thus in mediæval London the smiths lived in Smithfield, the bakers in Bread Street, and the saddlers around the Church of St. Martin-le-Grand, and the majority of the goldsmiths in Cheapside, while the allied trades of bowyers, fletchers and bow-string makers dwelt together in Grub Street.

It is interesting to note that the ordinances of the Craft Gilds reveal little or no attempt to limit the hours of labour, with the exception of the prohibition to work after the ringing of the curfew, or by candlelight. There was, however, some regulation of holidays, and the general rule seems to have existed that men should not work after 6 o'clock on Saturdays, or after noon had been rung on the days of a "double feast." There is a remarkable absence of any sign of the efforts to regulate employment in the interests of the workmen, which constitutes the predominant aim of Trade Unionism. A foreshadowing, however, of the dealings with non-unionists appears in an ordinance of the Gild of the Fullers, which was founded in I297, in that it was decreed: "If a stranger to the city comes in, he may, upon giving a penny to the wax, work among the brethren and sisters and his name shall be written on their roll." Another rule which appears in the same ordinance is of special interest, and is hard to explain save as an attempt to reserve the labour for the 
men. "None shall work at the wooden bar with a woman, unless with the wife of a master or her handmaid." Obviously the prohibition was not due to any objection to the laborious nature of the work of fulling, which was performed by treading the newly-made cloth in a trough, or by beating it with poles, for the master's wife and her handmaid were exempted from the regulation.

\section{COURTS OF THE CRAFT GILDS}

Most of the Crafts had power to deal with those who offended against their regulations in their own courts, though the right of appeal to the mayor rested with the accused. The courts were a specially marked feature of the London Companies and Crafts, and a definite jurisdiction was exercised over the Gild members by their means. Brethren were forbidden to carry their disputes before any other tribunal before they had been first heard by the officials of the Company. Judgment was given in the Gild courts on disputes concerning such matters as apprenticeship, the quality of the materials employed by craftsmen, and alleged attempts at fraud.

The executive authority of the Crafts was elected annually by the members, gathered together in full assembly. It consisted as a rule of a warden or wardens, overseers, searchers, bailiffs or masters, who possessed full powers to make and enforce trade regulations. The "searchers" were armed with considerable powers to aid them in their task of bringing offenders to judgment. We find, for instance, that the searchers of the Fraternity of Cordwainers and Shoemakers of Hull were entitled to search all premises, to inspect all tanned leather, and to mark it with stamp and seal. They were 
likewise empowered to seize all articles of bad workmanship, which were to be tried by the oath of six expert men within sixteen days. The fine for obstructing this work of inspection was no less than $f_{5 .} .^{1}$

The punishments inflicted by the courts of the Gilds consisted as a rule of fines. In the earlier days these were sometimes paid in wax for the altar-candles, or in wine or beer for the feasts. Confiscation of the inferior goods was resorted to, and in more serious cases, such as perjury or persistent law-breaking, the offender was expelled from the Gild. This exclusion, it need hardly be said, debarred him from continuing to practise his trade. The records of the Goldsmiths' Company contain much evidence of the disciplinary powers wielded by the society. Unruly apprentices were publicly chastised by the officers. In 1402 " two apprentices were whipped in the Hall, the master administering six cuts, and the Wardens three cuts each," and again in 1543, " an erring apprentice is stripped naked in the Hall and beaten." Stocks were kept in the Hall of the same Company " to punish wrongdoers in the sight and presence of the whole Company."2

To enforce the payment of fines, the Gilds sometimes adopted an expedient of which more was to be heard later, in connection with Trade Unionism, namely, "rattening." Dr. Brentano points out that in the case of the Gilds this power of distraint was accompanied by the right to sell the tools in order to reimburse the debtor's society. The Trade Unions, as unrecognised combinations, merely hid the tools of their members, as a means of coercion to induce them to obey rules or to pay their arrears. ${ }^{3}$

1 Two Thousand $Y_{\text {ears }}$ of Gild Life. J. M. Lambert. pp. 316-318.

2 Memorials of the Goldsmitbs' Company. W. S. Prideaux. Vol. I, pp. $16,51,78$.

3 English Gilds. p. cxxvii. 
An interesting document exists, relating to the Gild of the Tailors of Exeter, which gives a detailed account of the complaints taken before the court of that Gild, and also the judgments passed by the Master and theWardens. A customer complained that some of the cloth which he had given to a craftsman to make into a gown had disappeared. The finding of the officers of the Gild was, that though no cloth had been stolen, some had been wasted through the craftsman's lack of skill. The judgment awarded was that the tailor should pay for the injured material and should keep the gown. A vigorous master had chastised his servant with such severity that he bruised his arm and broke his head. The judgment passed was comprehensive and severe; the master was ordered to pay the doctor's bill, the servant's board, and heavy amends, in addition to a fine to the Gild. ${ }^{1}$

The ordinances contain innumerable rules which show how high at least were the aims of those who framed them. As in the case of the Religious Gilds, membership was conditional on the applicants bearing a high character; only brethren and sisters of fair fame were admitted to the societies. The sense of mutual responsibility amongst the members was also in some cases extended by them to their servants and apprentices. The tailors of Hull were ordered to bring their servants and apprentices to church on the Sabbath and other festival days, and were enjoined to restrain them from unthriftily using taverns and alehouses and playing unlawful games. ${ }^{2}$ Again, none were to resort to the ale-house in time of work, and those who showed themselves stubborn, forward, or wilful were to be fined. In a word, if rule and precept could have

1 Englisb Gilds. pp. 32 1, 322.

2 Tro Tbousand $r$ ears of Gild Life. J. M. Lambert. p. 235. 
secured perfection of behaviour and industrial honesty, the conduct of our forefathers would have been, without doubt, exemplary. The truism, however, that it is impracticable to make a nation entirely righteous by Act of Parliament, applies to the work of the Gilds. Rules were misconstrued, laws were evaded, and some of the regulations, though framed in plausible guise, were inspired by selfish motives.

It is, however, evident that the ideals which permeated many of the ordinances, coupled with the judicial work of courts of the Gilds, must have been of no inconsiderable value to the community generally in promoting a heightened standard of conduct in industrial and commercial affairs.

THE REGULATION OF APPRENTICESHIP

The custom of a lad becoming the pupil of a skilled craftsman for a definite time, in order that he might obtain manual dexterity and knowledge of the mysteries of a trade, is of ancient date. The word "apprentice" appears as early as the thirteenth century in an ordinance of the Lorimers of $\mathbf{1 2 6}$. Nevertheless, in the early days of the Craft Gilds a period of indentured service was not an essential preliminary training before a man was able to set up as a master-craftsman. He could in some cases obtain the freedom of the trade on testimony being afforded by the Gild officials, that he was possessed of sufficient skill to practise his craft. It appears, however, that by the beginning of the fifteenth century the custom of insisting upon a period of apprenticeship was becoming the rule, though the conditions and the length of the term of service were not yet rigidly fixed, and still depended to 
a large extent on the favour of the individual master. ${ }^{1}$ As the Crafts increasingly undertook the work of regulating apprenticeship, a term of seven years became the most usual period, though eight, ten, and even twelve years were occasionally demanded.

The period of seven years was that ultimately fixed by the important "Statute of Apprentices" of Elizabeth's reign, which exercised an extensive influence on English industrial history. It was thereby enacted that : "No one shall exercise any craft, mystery, or occupation, then used, or occupied within the realm of England or Wales, except he shall have been brought up therein seven years at the least as an apprentice, nor set any person at work in the same, except an apprentice, or one who, having served as an apprentice, becomes a journeyman, or is hired by the law." 2

It should be noted that the fact that this law was held to extend only to cities and market-towns, and likewise only to the trades of Elizabethan days, had an important bearing on the evolution of Trade Unionism and the Factory Acts. From the time that the rule of apprenticeship had become firmly established, a marked change is revealed in the spirit of the regulations, which were, as already intimated, primarily intended to secure adequate technical training for every craftsman. As the trade of the country expanded, and as competition increased, the terms of apprenticeship became more and more carefully defined, with the object of restricting the numbers of those admitted to the freedom of their Craft. This limitation of the number of full freemen, who alone had the legal right to produce or sell wares on their own

1 Economic History. W. J. Ashley. Part II, p. 85.

25 Eliz. c. 4. 
account, was effected in many ingenious ways. Efforts were directed towards checking the influx of apprentices to the Crafts, by putting difficulties in their way. For instance, by an Act of 1406 it was decreed that no persons unable to spend twenty shillings by the year should apprentice their children. ${ }^{1}$ Bondmen were habitually excluded from apprenticeship, and in London and probably other great cities, it was ordained that no foreigner should be enrolled as an apprentice unless he first declared himself on oath to be a freeman and not a villein. ${ }^{2}$ The Craft Gilds, in many instances, limited the number of apprentices which their brethren might employ, and sometimes provided for an interval of two or even four years to elapse between the enrolment of each. Attempts were also made to impose premiums and property qualifications for the admission to various trades, which occasioned great hardship.

Most of the industrial Companies in London limited the number of apprentices to three for a member of their governing body, two for one of their livery, and one for an ordinary member. Many Companies also required the apprentice, who wished to be admitted as a freeman, to prove that he was possessed of sufficient capital to set up on his own account, and also in some cases to produce a "masterpiece," or "proof-piece" in token of proficiency. ${ }^{3}$ The Goldsmiths for instance decreed in 1571 that "young men are not to set up for themselves until they have made their masterpieces." It has frequently been assumed that this custom of

17 Henry IV, c. 17.

2 Economic History. W. J. Ashley. Part II, p. 89.

3 Gilds and Companies of London. G. Unwin. pp. 264, 265.

4 Memorials of the Goldsmiths' Company. W. S. Prideaux. Vol. I, p. 75 . 
requiring a "masterpiece" played but a small part in English industry. The custom is known to have been largely used in both France and Germany as a device for excluding new members from the Crafts, and it is now beginning to appear that the same method was adopted during the sixteenth century in England more generally than has been supposed. Mr. Unwin indeed states that it seems probable that the requirement of the masterpiece had become general in London by the seventeenth century. ${ }^{1}$

The masters often resorted to even more dubious devices to check the careers of their own apprentices, the result frequently being that the man who had faithfully served his term did not receive his due reward -the freedom of the city. ${ }^{2}$ They appear in some instances to have extracted promises from these unlucky youths binding them to forego their rights of full-fledged craftsmen. An Act was ultimately passed to stop this form of oppression, which decreed that: "No master was to compel his apprentice to engage by oath or bond not to open a shop."3

An interesting testimony to the apprentices' very real need of protection from the selfishness of some masters is borne by the fact that the Fraternity of St. Mary in All Hallows, London Wall, offered to give legal or charitable help to any member whose son or daughter had been unjustly treated by the master to whom he or she had been apprenticed."

A net-work of restrictions such as we have described was bound to have a very irritating effect upon those

1 Gilds and Companies of London. G. Unwin. p. 265.

2 Ibid., p. 9 I.

322 Henry VIII, c. 4.

- Gilds and Companies of London. G. Unwin. P. 121. 
who aspired to enter the Crafts by means of a period of indentured service. In 1641 the feeling of exasperation under which the London apprentices laboured gave rise to a petition, which they presented to Parliament, at a time when the competition of foreigners was evidently adding to their sense of intolerable hardship. They found that their living was being taken from them by thousands of Frenchmen, Dutchmen, and Wolloons. "We by coercion," they complained, "are necessarily compelled to serve seven or eight years at least before we can have the immunity and freedom of this city to trade in: those which are mere strangers do snatch this freedom from us, and pull the trade out of our hands, so that by these means, when our times are fully expired, we do then begin in a manner to suffer a second apprenticeship to them, who do thus domineer over us in our own trades." They therefore begged that the privileges of their order might be better respected, and added the somewhat pathetic complaint that they were bound only to their own masters, "yet of late their mistresses had got the predominancy over them." 1

In the treatment thus accorded to the apprentices we find one of the weaknesses of the Gild system. The spirit of self-interest and the injustice which were not infrequently exhibited by the brethren, during the last centuries of Gild rule, constitutes a very serious blot upon the record of many of the Craft Gilds.

\section{SOCIAL ACTIVITIES OF THE CRAFT GILDS}

If the work of the organised Crafts had a profound influence upon the development of industrial life in

1 The Apprentices of London's Petition to the Honourable Court of Parliament, 1641. British Museum Library. 
England, it must also be remembered that the Gild system was closely interwoven with the social activities of the citizens of the Middle Ages. The Gilds concerned themselves not only with all that was "commodious and serious," but also with much that was both " merry and sportful."

Stow, in his delightful account of the "sports and pastimes of old time," provides valuable information with regard to the amusements of the people of London, amongst which figured maying, cock-fighting, bullbaiting, mummery and feasting. He conjures up a picture of a gay city where mock warfare, jousts and tourneys made glad the heart of man. "In the holidays all the summer the youths are exercised in leaping, dancing, shooting, wrestling, casting the stone and practising their shields, the maidens trip in their timbrels, and dance as long as they can see." 1

It was, however, with the pageants which were frequently held in London that the Gilds and the twelve great City Companies were more especially connected. Stow gives vivid descriptions of these "triumphant shows," which were organised to commemorate great public events, such as a royal birth or marriage, or a victorious conclusion to a war with a foreign power. They were the visible expression of the glad heart-beats of the civic life of the period.

A typical pageant was presented to commemorate a victory against the Scots in the year 1293, when it appears that all the Crafts and Companies bore a share and contributed some part of the show. The Fishmongers evidently produced the most remarkable display, for it is recorded that they marched in procession through the

1 Survey of London. Stow. p. 35. 
City, "having amongst other pageants and shows, four sturgeons gilt, carried on four horses; then four salmons of silver on four horses; and after them six and forty armed knights riding on horses, made like luces of the sea ; and then one representing St. Magnus, because it was upon St. Magnus' Day, with a thousand horsemen."1

"The custom of "setting out the watch," or the "marching-watch," which was kept on Midsummer Eve in London, Bristol, Worcester, and other towns, is of special interest. It was a kind of military muster, which originated in the part taken by the Trade Gilds in the defence of the City. An interesting record of the Court of Assistants of the Goldsmiths of 1642 indicates that a share in the responsibility of defending the City of London was recognised, even in the seventeenth century, as resting with the Companies: "A precept from the Lord Mayor is received asking for a certificate of the quantity of arms, ammunition, matches, powder, and shot, which the Company have for the defence of the City, and requesting them to provide an engine for preventing fire if any should happen." The Company decided forthwith to increase their supply of arms and ammunition on the grounds that "most of the twelve Companies are better provided than this Company."2 .

On the Continent the work of defence was frequently undertaken in this manner by the Gilds, and an association was founded at Ghent in the sixteenth century composed of culverineers, arquebusiers, and gunners, in order to teach the townsmen the use of firearms, wherewith to defend the town and keep the peace.

1 Survey of London. Stow. p. 37.

2 Memorials of the Goldsmiths' Company. W. S. Prideaux. Vol. I, p. 202. 
The Midsummer Watch was held in London after its entirely military character had disappeared. That it was a celebration of extraordinary interest and beauty is shown by Stow's account of the pageantry, of which he was himself doubtless an eye-witness:

"On the vigil of St. John the Baptist, and on St. Peter and Paul the apostles, every man's door being shadowed with green birch, long fennel, St. John's wort, orpin, white lilies, and such like, garnished upon with garlands of beautiful flowers, had also lamps of glass, with oil burning in them all the night; some hung out branches of iron curiously wrought, containing hundreds of lamps alight at once, which made a goodly show, namely in New Fish Street, Thames Street, etc. Then had ye besides the standing watches all in bright harness, in every ward and street of this city and suburbs, a marching watch that passed through the principal streets thereof ... The marching watch contained in number about two thousand men, part of them being old soldiers of skill, to be captains, lieutenants, sergeants, corporals, etc., wiflers, drummers and fifes, standard and ensign bearers, sword-players, trumpeters on horse back, demilances on great horses, gunners with hand guns, or half hakes, archers in coats of white fustian, signed on the breast and back with the arms of the city, their bows bent in their hands, with sheaves of arrows by their sides, pikemen in bright corslets, burganets, etc., halberds, the like billmen in almaine rivets, and apernes of mail in great number; there were also divers pageants, morris dancers, constables, the one-half, which was one hundred and twenty, on St. John's eve, the other half on St. Peter's eve, in bright harness, some over gilt and everyone a journet of scarlet thereupon, and a chain of gold, 
his henchmen following him, his minstrels before him, and his cresset light passing by him, the waits of the city, the Mayor's officers, for his guard before him, all in a livery of worsted, or say jackets party-coloured, the mayor himself well mounted on horse back, the sword bearer before him in fair armour well mounted also, the mayor's footmen, and the like torchbearers about him, henchmen twain upon great stirring horses, following him."1

Such, then, was a typical procession, illuminated by some thousand lights, borne by those who formed it, which delighted the spectators of mediæval London.

The continuity of this custom was broken by Henry VIII in 1539. An unusual muster having taken place in that year occasioning "great charges of the citizens," the King forbade the further expenditure which would be involved by holding the annual marching-watch. Though the custom was revived a few years later during the mayoralty of Sir John Gresham, it again soon fell into disuse, and as it ceased to be held the Lord Mayor's Show came to be, as it is at the present time, the one great civic pageant of the year, and the one echo of the elaborate pageantry promoted and fostered by the Gilds and Companies of the Middle Ages.

Of the more private social activities of the Craft Gilds we have less knowledge. Their corporate life was, however, stimulated by the meetings of the smaller Mysteries in the houses of their members, and by the sumptuous and ceremonious feasts held in the great halls of the City Companies, where the aristocracy of trade debated on the regulation of industry and the bestowal of charity.

1 Survey of London. Stow. p. 39. 
That this inner life of the Gilds fostered a spirit of fraternity and active benevolence there is considerable evidence. The liberality of the London Companies at the present time, and the services which they render to education and innumerable charitable causes, are manifestations of the same spirit of associative effort which inspired our forefathers.

The Fishmongers were amongst the most munificent donors to religious objects of all the citizens of London. Half-a-dozen riverside churches were endowed and rebuilt by their bequests. ${ }^{1}$

The members of the Livery Companies frequently left sums of money or of land to be devoted to charitable purposes by their Company, or the Fraternity which was linked with it. For instance, in 1446 the Vintners were bequeathed some property by one Guy Shuldham, on condition that "they should bestow thirteen little mansions lying together ... upon thirteen poor and needy men of the mistery," each of whom was to receive an allowance of one penny a week. Similarly, in 1454, Thomas Beaumond, a Salter, left to the Fraternity of Corpus Christi divers lands and tenements and six houses in which six poor members of his art "were to be maintained as bedesmen, receiving a weekly sum of sevenpence."

A curious benefit of the Goldsmiths' Company is interesting as an early acknowledgment of the claim of those who were injured by dangerous processes in production. The Company undertook to relieve those "who by fire and the smoke of quicksilver have lost their sight." In 1618 the same Company awarded charity to a very

1 Gilds and Companies of London. G. Unwin. p. 94.

2 Ibid. pp. 182, 183. 
poor goldsmith with a wife and six children, "and much weakened by gilding." 1 The frequent references which are to be found among the records of the Company indicate that the Goldsmiths were not only careful of the welfare of their own members, but extended charitable help to many outside their craft.

It is obvious, indeed, that in the case of the London Companies, their daily activities at the present time, " combining those of a ducal estate-office, with those of a charity organisation office, and a department of technical education," are constant witnesses of the charitable spirit which was manifested by them during past centuries.

With regard to the country generally, but little inherited testimony remains of the work of voluntary mutual assistance accomplished by the Craft Gilds. The ordinances of the Crafts dealt mainly with such matters as the regulation of the processes of industry, and the control of apprenticeship, for the simple reason that the action of the Gild brethren in the supervision of production was the direct concern of the City anthorities. The charitable help which the Crafts afforded was their private concern. It must not, howerer, be inferred from the comparative absence of rules relating to their internal life as Friendly Societies, that this aspect of the work was unimportant or neglected. Time has obliterated, in a measure, the means of discovering the full extent of the work of mutual help which they undoubtedly performed. Traces, however, are to be found in some of the ordinances, such as those of some of the Crafts of Hull which reveal that many of the essentially Friendly Society

${ }^{1}$ Memorials of the Goldsmiths' Company. W. S. Prideaux. Vol. I, p. 129. 
characteristics were present in the work of the Craft Gilds.

It appears that it was customary for the societies to possess a "common-box," from which sums of money were paid to those members of the trade who had fallen into poverty, who were aged, or unable to work. It was also usual, as in the case of both the Religious and the Merchant Gilds, to provide for the expenses connected with the burial of members, and in many cases also for vigils and masses for the dead.

The torch of mutual help which was kindled in England in the associations of Saxon days was still being passed from hand to hand through the Middle Ages, and among the agencies which served to keep the flame alive we may assuredly name the Craft Gilds. 


\section{CHAPTER VI}

\section{THE DECLINE OF THE CRAFT GILDS}

AN impression has sometimes been given that the work of the Trade Gilds having been rudely destroyed at the Reformation, an unexplained gap existed in the history of voluntary associative effort, between the extinction of the Gild system and the birth of the Friendly Societies and Trade Unions. It has, however, now been established that some measure of authority was maintained in some instances by Gilds until the end of the eighteenth century. Friendly Societies made their first appearance during the seventeenth century, and Trade Unionism dates from the reign of Queen Anne. It is indeed apparent that there was no chronological gap in the organised manifestations of the ever-living principle of mutual aid. The different forms of association in which men united to share life's burdens and responsibilities overlapped in point of time. Though the dying Gilds, to make use of the simile of the previous chapter, gave an ever waning light, and the new-born Friendly Societies emitted but a feeble gleam, the torch of associative effort still burnt on, its fire was never extinguished. 
The destructive effects of the Reformation upon the Trade Gilds have been very much exaggerated. Recent research has served to prove that though considerable changes were effected by the confiscatory Acts, the main current of the Gild activities flowed on, unhindered by the revolution in religious thought and observance of the sixteenth century. Of the London Gilds and Companies, Mr. Unwin writes: "Their social gatherings, the administration of their charities, their regulation of industry and trade, were not disturbed; and even their religious observances, although reduced in importance and largely disendowed, were by no means entirely abolished." 1 Professor Ashley is convinced that: "There was no violent break in the continuity of craft development, that the old Gild organisation continued to exist in the towns and in most industries, and that when and where it passed away its death was due to slowly acting economic causes, and not to the act of $1547 .{ }^{\prime \prime 2}$

The great landmark of industrial change in England is to be found in the eighteenth and not in the sixteenth century, and coincident with this industrial change were the destruction of the Gild system, and the inception of new forms of voluntary societies which were more adapted to the altered requirements of the working classes.

The processes which led to this reconstruction were gradual in their operation before the introduction of machinery, and it is necessary for us to attempt to determine their nature. It is important to note that these processes were of a two-fold character. On the one hand, the seeds of decay were germinating which were inherent

1 Gilds and Companies of London. G. Unwin. p. 202.

2 Econcmic History. W. J. Ashley. Part II, p. 155. 
in the Gild system, and which may be described as the internal causes of degeneration. On the other hand, external forces were combining, for at least two centuries, to render obsolete the ancient forms of industrial organisation.

During the latter part of the sixteenth, and the whole of the seventeenth century, a great change was taking place in the constitution of the Craft Gilds. Many of these associations ceased to consist exclusively of the men engaged in one mystery or craft, but were composed of the members belonging to a larger number of industrial groups. Sometimes as many as a dozen of these units were thus formed into one society. In some instances the trades which were united in this manner were closely linked by reason of the allied nature of their occupations. The weavers, for example, united themselves with the fullers. In other cases the Companies were composed of an entirely heterogeneous collection of trades. ${ }^{1}$ At Wallingford, for instance, in 1663 , "it was ordained that all trades within the borough should consist of one body to be called the Company of Drapers.""2

The inevitable result of this new movement was, that the old supervision of the minutix of the technique of manufacture became impossible, and the work of the "searchers" of the Gilds was gradually abandoned. The increasingly complex constitution of these organisations served in this way to weaken one of the mainstays of Gild influence.

Another source of weakness, which was developed within the Gilds themselves, was the ever-growing spirit of self-interest, and the consequent efforts to restrict the

1 Economic History. W. J. Ashley. Part II. pp. 161, 162.

2 The Gild Mercbant. C. Gross. Vol. I, p. 121. 


\section{THE AGRARIAN REVOLUTION}

number of admissions to the Crafts, which have been already noticed. The Gilds and Companies grew more and more into close corporations, and in some cases even endeavoured to confine the monopoly of exercising a trade to the family group. These symptoms, by a curious irony, were increasingly exhibited just as industry was receiving so strong an impulse throughout the country as inevitably to render such attempts abortive. The Crafts, with extraordinary blindness as to the real strength of the tide which was surging in and threatening to engulf them, clung with increasing tenacity to their monopolies.

Economic forces were too strong for them. During the "Agrarian Revolution" men were flocking into the towns demanding employment. The fact that the land was being devoted to sheep-rearing rather than to the growing of crops caused a great dislocation of labour. Many of the men who were no longer required to guide the plough desired to take part in the flourishing weaving industry. The consequence was that the woollen manufacture, the old staple trade of England, which had been the first to inaugurate the Gild system, was the first to expand beyond its limits, and to throw off its trammels as no longer supportable. Apprenticeship, as the door to mastership, and other trade regulations were thrown to the winds. Among the other economic causes which contributed to this result was the rapid growth of a foreign demand, which served to create a class of dealers or middlemen, who bought the finished wares and undertook the sale of goods, thereby leaving the mastercraftsmen to give undivided attention to manufacture. The occupations of producer and trader were becoming more and more distinct. 


\section{I04 DECLINE OF THE CRAFT GILDS}

During the sixteenth century there were marked signs of growing enterprise on the part of enployers in the woollen industry. A larger number of men were being employed by some of the cloth-makers under one roof. Professor Ashley illustrates this point, in his interesting account of the development of the staple trade, by reference to "Jack of Newbury," who became one of the heroes of seventeenth century chap-books. Tradition held that he kept a hundred looms at work in his own house, and marched at the head of a hundred workmen to the battle of Flodden Field. A pamphlet, the first edition of which is said to have been printed in 1597 , gives a highly coloured account of this large employer's prosperity. It opens with the lines :-

"Within one roome being large and long

There stood two hundred Loomes full strong:

Two hundred men the truth is so

Wrought in these Loomes all in a row."

The doggerel goes on to relate that in addition to the two hundred men thus engaged in weaving, a "pretty boy" was required at each loom, a hundred women were employed in carding, while two hundred maidens, adorned with "milk-white kerchers," were spinning. A staff of sheremen, rowers, dyers and fullers are described as having completed the number of those who were engaged in this precocious industry. ${ }^{1}$ During the era of trade expansion, which dates from about this time, the application of new inventions to the methods of production rendered the Gild standards of manufacture no longer applicable. The old permanence in both materials and methods was superseded in industry after industry by new processes which, culminating in the introduction of machinery, rendered the old regulations out-of-date.

1 Economic History. W. J. Ashley. Part II, pp. 229, 255. 
The towns, too, were steadily growing in size, and the system of trade organisation, which had been formed to meet the need of small communities, was incapable of holding its own when the population increased with such rapidity that the "aliens" pouring into the towns out-numbered the home-born men. The old conditions, by which the local trade in each town was hedged in by barriers and restrictions, were giving place to a national trade with wider markets.

The results were that both the Crafts and the municipal authorities continually lost their importance, and new trades grew up completely outside Gild control. The Legislature, even as early as Tudor days, tended to accelerate the processes of change. Parliament began to undertake increasingly the functions which had previously been performed by the Gilds. The determination of the number of apprentices, the regulation of the technique of manufacture, the settlement of trade disputes, were all regarded as matters which required Government jurisdiction. The Gild responsibilities were therefore gradually wrested away, and centralised Government tended to supersede local control. The Elizabethan "Statute of Apprentices," for instance, dealt a very severe blow to the Gilds. This Act transferred the jurisdiction over the apprentices and journeymen from the Crafts to the Justices of the Peace. ${ }^{1}$

Such, then, were some of the economic causes which were having their effect upon diverse trades and in various parts of the country as early as the sixteenth century. The same causes were during the seventeenth century silently and irresistibly sapping the life of the Gild system throughout Great Britain. The work of destruction was

15 Eliz., c. 4 . 
practically completed by the close of the eighteenth century.

The invention of machinery, scientific and rapidly changing methods of production, the construction of turnpike roads and canals, increasing the means of transport and the fluidity of labour, and finally the railway and the steamship, which opened up the markets of the world-all in fact which contributed to create the Industrial Revolution-rendered the continuance of the Gild system, or its revival, an absolute impossibility.

The final process of the dissolution of the Gilds has been admirably described by Mr. Lambert: "The surrounding force was overwhelming and irresistible. The ordinances remained, but no one could enforce them. The brethren passed rules and imposed fines, but the rules were disregarded and the fines remained unpaid. Still they met yearly, elected their warden and searchers, ordered their dinner and displayed their plate. At length the dinner was deserted, the silver tobacco-pipe was unlit, and the punch bowl cold. What were they to do ? In most cases they passed silently into oblivion; the remains of plate passed into private hands; the books disappeared. In a few the surviving officials met, presented a faithful account of their stewardship, and solemnly bequeathed their records and the few remnants of their plate to the Town's Chamber."1

It is interesting to remember that an obstacle was placed in the way of Watt, whose ingenuity and labour were to transform industry, by the Gild system to which he dealt a death-blow. He could not legally sell his inventions in the city of Glasgow for the reason that it was not his birth-place, and was obliged to take refuge

$1 \tau_{\text {wo }}$ Tbousand Years of Gild Life. J. M. Lambert. p. 192. 
within the University. The laws of corporate monopoly rigidly excluded him, and the Company of Hammermen insisted on the exclusion being maintained, for fear of "loss and skaith to the Burgesses and Craftsmen of Glasgow by the intrusion of strangers."

In London, the struggle of the Companies to maintain their supremacy and continued supervision of manufacture lingered on, in some few instances, into the nineteenth century. The Saddlers' Company continued to institute "nine annual searchers" as recently as 1837 . If defective goods were found they were borne off to the Saddlers' Hall, and if condemned by the opinion of eight or ten respectable saddlers, the articles were destroyed. ${ }^{1}$ It may also be noticed that, though the actual searches and the minute regulation of production are no longer attempted at the present day by the City Companies, two or three of them, including the Fishmongers and the Goldsmiths, still possess very considerable disciplinary powers, which they exercise vigorously in the interests of the public and of their respective trades. One anachronism has lingered on from the Gild system until the present time, in the monopoly held by the Watermen's Company, which has been an incorporated society of transport workers on the Thames since 1555. It was not until the Port of London Authority was constituted that the monopoly of this society was seriously threatened. It has thus served as a reminder, in the twentieth century, of a system of industrial organisation which has long since expired, and which owed its first inception to voluntary association. ${ }^{2}$

1 Gilds and Companies of London. G. Unwin. p. 345 .

2 If the by-laws which have been recently made by the Port of London Authority receive the final sanction of the Board of Trade and are put into operation, they will have the effect of terminating the monopoly (April, 1913). 
We find in the Gild system, as in all institutions of human origin, that good and evil were inextricably mingled. Foremost amongst its merits is the fact that it was constructed upon a broad social basis, and its members were drawn from several social grades. The result was that it succeeded in a measure, for several centuries, in reconciling the interests of the small employers and their workmen. In attempting to estimate the achievements of the Trade Gilds it must be remembered that the industrial record of many centuries affords the best testimony to the value of Gild control. The infant industries thrived in a remarkable manner, and a prosperous middle-class sprang into being under the ægis of the Gilds. The arts and crafts rose to a degree of perfection which was previously unequalled, and has never been surpassed. The cathedrals and medixval churches which were built by Gild brethren are enduring witnesses to the inventive skill and the patience with which the craftsmen of the past performed their work. And again, the Gild system raised and maintained the dignity of manual labour. The true craftsman was a respected artist, and a man who was proud of his trade. His responsibilities to his Gild, for the performance of true work, aroused in him a sense of responsibility to the community generally.

With rare wisdom, the interests of both the prodcuer and consumer were taken into consideration by the Trade Gilds. The consistent aim which permeated their regulations was to secure a high quality of workmanship on the part of the craftsman, coupled with an honest price to the buyer, and a fair wage to all those employed in 
industry. The painstaking spirit which inspired the minute regulations affords an enduring lesson to the modern industrial world.

It is sometimes maintained that the close supervision tended to stereotype methods, and to check individual initiative and resource. The all-pervading control had its advantages, even if this was the case: "In every stage of social evolution there are particular needs which have to be met, and particular tendencies in human character which call either for repression or stimulus; and speaking generally we may say that in the later Middle Ages the time had not yet come for the free play of individual enterprise. It was rather a time when the elementary conceptions of good and honest work needed to be driven into the general conscience by minute rules vigorously enforced; when what was required was discipline rather than spontaneity." 1

It is indisputable that such discipline was needed; the standard of commercial morality was low, the tendency to scamp work was often present, and we may assume that the industrial organisation of the period was well fitted to meet the requirements of its environment. With regard to the value of the contribution of the Gild system to the evolution of associative effort, which is our main concern in this volume, we find evidences of both failure and success. The influence of the Gilds in training men industrially and as citizens can hardly be estimated too highly. The spirit of brotherhood which grew up within the confines of the Gilds was of real and lasting value; and the principle of mutual aid, which was perpetually recognised, formed the basis of all subsequent working-class combinations.

1 Economic History. W. J. Ashley. Part II, p. 168. 
The conception of brotherhood was, however, a narrow one, and did not stretch beyond the confines of the town, or indeed frequently even beyond the borders of the Craft itself. This narrow outlook was the cause of the miserable failure, which, it must be admitted, is apparent in the days of the degeneration of the Crafts. We have already shown that self-interest became one of the chief motives guiding the Gilds' actions. The methods were often harsh, oppressive and tyrannical, not only to the "aliens," but to the apprentices and journeymen who were desirous of obtaining the freedom of their Craft.

If we accept Sir Frederick Eden's criterion of a successful government, that: "under its sway there is employment for all the people," we must admit that in Plantagenet and Tudor England there was signal failure, for which the industrial organisations were partially responsible. A study of the numerous laws passed to suppress sturdy beggars, rogues, and vagabonds, during the years when the Gild system was holding the helm of industry most firmly, serves to prove how urgent was the problem of unemployment during the Middle Ages, and how profoundly it perplexed the statesmen of the period. Law succeeded law, enacting horrible penalties against those who roamed through the country unable to, or undesirous of, earning a living.

A description of the condition of Somersetshire, written in the year 1596, by a Justice of the Peace, affords an interesting illustration of this point. Strype stated that: "Forty persons had been executed in a year for robberies, thefts and other felonies; thirty-five burnt in the hand; thirty-seven whipped; one hundred and eighty-three discharged; that those who were discharged were most wicked and desperate persons, who 
never could come to any good, because they would not work and none would take them into service; that, notwithstanding these great numbers of indictments, the fifth part of the felonies committed in the county were not brought to trial."1

Harrison's cynical observation that: "Rogues were trussed up apace in Elizabeth's reign," appears to have been no exaggeration, and it is evident that the industrial system of Tudor England did not succeed in providing work for all!

Nevertheless, when all the aspects of Gild activity are weighed in the balance, we cannot fail to conclude that the Gilds and Companies contributed much which was valuable to the social, religious and industrial welfare of our country, and bore a share, the importance of which can hardly be overrated, in building up our civic and national life. The Gild brethren had a vision, and they formulated ideals. If the vision was narrow and the ideals were often unattained, yet the part which they played in the history of associative effort has been of immense service to civilisation.

1 Strype's Annals. Vol. IV, p. 290. 


\section{CHAPTER VII}

\section{THE INDUSTRIAL REVOLUTION}

To understand aright the causes which spurred the working classes of England to combine, with renewed energy, during the nineteenth century, it is necessary to examine in some detail the chief features of the vast industrial changes, which took place from about $177^{\circ}$ onwards, and their effect upon a considerable proportion of the population.

The predominant characteristic of the Industrial Revolution was the substitution of universal, unfettered competition for the old restrictions which were the very essence of the Gild system. The new belief which gained acceptance was, that the freedom of each man to pursue his own individual interests was the surest guarantee of national prosperity and general well-being. The followers of this faith, however, failed to reckon with certain weaknesses of unregenerate human nature. The fact that the equitable distribution of wealth was infinitely more important for the true welfare of the nation than its rapid acquisition, was not realised.

The student of this period of our industrial history 
has perforce to make his way through a veritable "Valley of Humiliation." He is obliged to examine the results of callous selfishness, of a reckless indifference to consequences involving the loss of health and well-being of multitudes, and of a blind and theoretic adherence to exaggerated forms of the doctrine of laisser-faire in unrestricted competition.

The ethical standard of the age was utterly unequal to support the strain which was cast upon it, when machinery rendered the accumulation of large fortunes a new possibility. The national conscience slept while horrors and iniquities were perpetrated which are perhaps unsurpassed in the history of industry in any civilised country.

From the middle of the fifteenth to the middle of the eighteenth century the "domestic system" of manufacture predominated in England. The business of production was mainly in the hands of small mastermanufacturers. These employers lived in country homesteads, renting and working small pasture farms, and employing, under their own roofs, journeymen and apprentices in spinning, weaving, and dyeing. Few of such employers owned more than four looms, or employed more than eight or ten people. Men, women and children all worked together. Men who conducted manufacture on the large scale of "Jack of Newbury" were evidently rare.

In the report of a Parliamentary Committee of 1806 the prevailing type of manufacture is described as " conducted by a multitude of Master Manufacturers generally possessing a very small, and scarcely ever any great extent of Capital. They buy the wool of the Dealer; and in their own houses, assisted by their wives and children, and from two or three to six or seven Journey- 
men, they dye it (when dyeing is necessary), and through all the different stages work it up into undressed Cloth." The cloth thus made was carried to the neighbouring towns, and sold in the public markets.

Though in some parts of England "captains of industry" had risen from the ranks of the small masters, home manufactures, conducted on a small scale, prevailed throughout the kingdom at the beginning of the eighteenth century. In many parts of the country, homeweaving was so general that every farm-house had its spinning wheel, and every village possessed a loom.

Those whose trade was weaving were frequently in a position to rent a piece of land. Though the farming was indifferent and the crops produced were poor, this circumstance afforded them variety of employment, and no doubt helped in some measure to improve their material condition. If life was dull, it was at least peaceful; if the horizon was narrow, it was undisturbed by storms; if intellectual activity was dormant, the perplexing problems of the new industrial era were not yet formulated. Though fortunes were small, the position of those engaged in industry was reasonably secure. Wages and employment were, for the trained craftsman, regular; the fearful sufferings which were to be borne by succeeding generations, caused by the fluctuations of the market, were, generally speaking, unknown. The tie between employer and workman was a close one, and even if the relation was not always idyllic, it endured sometimes throughout a lifetime, and was an essentially human one. The workman ate at his master's board, his sickness was a matter of real importance to all engaged with him in an industry conducted on so small a scale. His welfare constituted a definite factor in the success of the enterprise in which he 
was employed. Finally, he had still the hope, in many trades, of becoming a small master in his turn. Such, then, in briefest outline, was the condition of the woollen industry in the north of England, and of many trades throughout the country, when the existing methods, habits, and theories were swept away before a whirlwind of change.

The series of inventions which were to give England the foremost place in material prosperity among the nations of the world appeared during the last half of the eighteenth century. With James Hargreaves, a Lancashire man, rests the honour of having produced in 1770 a remarkable labour-saving device in the spinning-jenny; this machine carried sixteen or eighteen spindles instead of only one. As it could be manipulated by a single workman, the output was enormously increased. This invention immediately gave a great stimulus to weaving. The price of cloth dropped, the demand rose. The master-weaver was enabled to earn more, and began to set up spinning-jennies in large buildings and to drive the machines by water-power. So arose the Factory system. Arkwright, Crompton, Cartwright, Kelly and Roberts all added their quota of invention to perfect the machinery which was fatal to the domestic system in the textile industries. At the very time that they were working to improve the methods of manufacture, Watt was labouring to apply the steam-power which was to drive the new machinery.

Coincident with the new impulse in the woollen manufacture was the extraordinary growth of the cotton industry, which converted Lancashire from an "illcultivated swamp" into the busiest industrial centre in England. India had practically possessed the monopoly 
of the cotton trade before the introduction of machinery. Incomparably the most beautiful and artistic materials, which were described by the Hindoo poets as "woven wind," issued from the Dacca looms. Machinery, however, wrested the trade from the East, and though it was impossible to imitate the beauty of the fabrics, the comparatively cheap goods produced in England created a new demand. From "East and West and South and North" "hands" poured into Lancashire, hoping to share in the profits of the growing cotton trade. Amongst them were crowds of Irish, who crossed St. George's Channel to take their place in the ranks of the new army of industrial workers.

It is easy to see how the mighty movement, once started, spread from one trade to another. The invention of machinery driven by steam gave the coal-fields of England a new importance; and the demand for iron gave the impulse to inventive faculty to find new means of smelting the ore. The old plan of smelting in charcoal furnaces, blown by leather bellows worked by oxen, was superseded by the introduction of huge blast-furnaces in which coal was used instead of wood, and to which the steam engine was applied. The result was that the metal was turned out so cheaply that a number of objects which had previously been made of stone and wood were thenceforth made of iron. The first bridge partially constructed of iron was built over the Severn in 1779 , a forerunner of the huge structures which have been erected in our own day in all the quarters of the globe. The construction of machinery and implements was greatly facilitated and cheapened by a new method of casting steel which was discovered in 1790 .

This extraordinary activity in invention and production 
was not confined to the cotton, woollen and mining industries, but spread to a host of other trades. Wedgwood, by his technical skill and the beauty of his designs, gave a great impulse to the pottery trade. A newlyinvented stocking-loom, and the lowered price of yarn, revolutionised the hosiery manufacture of Nottingham and Derby. A lace-making machine invented in 1777 , which simplified production and reduced cost, gave a new birth to the lace industry in Nottingham, Leicester, and the West of England. The lowering of the duty on silk gave a fresh impulse to the manufacture of silk materials. All industries allied with the cotton trade, such as bleaching, dyeing, and printing, were benefited by a brilliant series of inventions, and shared in the general advance. It is not too much to say that, in all branches of human effort, invention and enterprise were stimulated by a new whirl of activity.

The growing demand of foreign countries for manufactured goods, and the increased home demand for raw materials, led to the rapid growth of our shipping, and to a new prosperity in the carrying trade, which was revolutionised by the launching of the first steam boat in 1812. The system of internal communication was developed and improved. New bridges and aqueducts spanned the rivers. River-beds were dredged and deepened to render the streams more navigable. A new system of canals, which was opened throughout the country, cheapened transit. In 1777 the Grand Trunk Canal, 96 miles in length, connecting the Trent and the Mersey, was finished; Hull and Liverpool were connected by one canal, while another joined them both with Bristol; and in $\mathbf{1} 792$ a new water-way was made from London through Oxford to the chief midland towns by 
the construction of the Grand Junction Canal. ${ }^{1}$ Between the years 1818 and 1829 more than a thousand additicnal miles of turnpike roads were created, and nearly all the old roads, in which the coaches of our forefathers had not infrequently stuck fast in the mire, were re-made on the new system of Macadam. Arthur Young's experience before the roads were thus reconstructed was doubtless common enough. He complained that on the "infernal road" between Preston and Wigan the ruts were four feet deep, and in one hour he saw three carts break down in the course of a mile. The most important factor in the revolution in methods of transit, was, it need hardly be said, the inauguration of the Railway system. From the year 1825, when the first train ran from Stockton to Darlington, new paths have been successively opened up to facilitate the rush of trade to all parts of the world, and life has abounded in new possibilities.

Changes of the radical nature which I have described, which took place throughout the length and breadth of the land, and in every branch of industry, necessarily had a marked effect upon agriculture. The most noticeable result was a relative and positive decline in the agricultural population. The countrymen were crowding to the manufacturing centres. In consequence of this migration, a large number of the small holdings fell idle, and upon these a new class of tenant farmers established themselves and farmed on a larger scale, holding fifty, one hundred, or even as many as five hundred acres. This tendency to consolidate the farms reduced the number of farmers, as may be illustrated by an account of a holding in the parish of Burghclere in 1826. Cobbett wrote : "One single farmer holds under Lord Carnarvon,

${ }^{1}$ Industrial Revolution. Arnold Toynuce. p. 71. [Reprinted 1912.] 
as one farm, the lands that those now living remember to have formed fourteen farms, bringing up in a respectable way fourteen families." 1

During this "agrarian revolution," which was taking place simultaneously with the transformation of industry, an extraordinary increase of enclosure on a large scale also served to drive the labourers from the land. It became impossible for many of them to obtain an independent livelihood when they had lost their rights of pasturage for cattle, sheep, and geese, and the privilege of collecting fuel from the common lands. The rapidity with which this vast change was accomplished may be illustrated by the fact that over $5,000,000$ acres were enclosed during the reign of George III, as compared with some 300,000 during the previous fifty years. Whatever view may be taken of the equity of the process, and of the penury and suffering which it caused among the agricultural population, it may be claimed that it was the cause of the adoption of improved methods of farming. Capital began from this period to play a larger part in the cultivation of the soil. Much inferior land was brought into cultivation, and by means of the scientific rotation of crops, improved breeds of cattle, and the use of the steamplough, there was a large increase in the agricultural produce of the country.

EFFECTS OF THE INDUSTRIAL REVOLUTION ON THE WAGE-EARNERS

Our task is now to consider the effects of these farreaching changes upon the wage-earners, and to endeavour to understand something of the degradation and suffering of the factory and mining population which induced William Cobbett to write in 1822 , in bitterness of

1 Rural Rides. Cobbett. p. 579. 
spirit: "England now contains the most miserable people that ever trod the earth. It is the seat of greater human suffering, of more pain of body and mind, than was ever before heard of in the whole world." With the beneficial effects of the Industrial Revolution on large sections of the community, and notably on the middle classes, I do not propose to treat; our concern here is merely with the wage-earners and the impulse which the new conditions afforded to associative effort. It is first necessary to guard against giving the impression that the transition from the "Domestic" to the Factory system was eitherinitiated or completed throughout the whole field of industry at the same time, or is indeed completed yet. I shall have occasion to show, when I attempt to trace the early history of Trade Unionism, that in some parts of the country, notably in the West of England, capitalist employers were organising industry on an extensive scale, long before steam was applied to machinery. It must also be borne in mind that the new system of production has not yet become all-embracing-in some industries the workers are to this day largely employed in domestic workshops and in their own homes. Mr. Charles Booth has shown to how great an extent this is still the case in East London, and the domestic system still prevails in the chain and nail-making trades of the Black Country.

It may, however, be asserted with some confidence, that the condition of the majority of those left working under the older system has been depressed, rather than raised, by the introduction of machinery and of manufacture on a larger scale. Competition has told heavily against the home worker and the small employer. This was especially the case with regard to the operatives who 
struggled, during the early years of the Industrial Revolution, to continue to produce by hand the very articles which the factories were pouring forth with the help of machinery. The sufferings, for instance, of the weavers who were not absorbed into the factories were great. Their earnings fell, and they toiled for increasing hours in a vain effort to earn a livelihood by the old methods of weaving. This depression was felt in trade after trade as machine labour began to compete with hand labour.

It is not surprising to find that bitter resentment was aroused by this circumstance. Machinery was sometimes attacked and destroyed, and mills were burnt, by those who had suffered from the first effects of the introduction of machinery.

The lot of the spinriers and weavers who were actually engaged in the factories was for a time in some respects improved. The first result, as far as they were concerned, was a rise in wages. The period from $\mathbf{1} 788$ to 1803, during which the cotton industry trebled itself, has been called the "golden age." The demand is described as having become so great that "old barns, cart-houses, out-buildings of all descriptions, were repaired, windows broke through the old blank walls, and all fitted up for loom-shops; new weavers' cottages with loom-shops arose in every direction, every family bringing home weekly from 40 to I $_{20}$ shillings per week." 1

It must also be remembered that the consumers of all classes benefited to some extent by the cheapened production. The working classes found commodities within their reach which had been previously unobtainable. The luxuries of the past were tending to become the necessities of the present, and the whole standard

${ }^{1}$ Industrial Revolution. Arnold Toynbee quoting Radcliffe. 
with regard to the requirements of life was gradually changing.

There is, nevertheless, abundant evidence to prove that the suffering connected with the new era of industrial life had, even during those early years, begun to be felt intensely. One of the most prominent features of the new régime was a reckless exploitation of child labour. There had been no inconsiderable abuse of child labour in the small workshops of the past, ${ }^{1}$ but the introduction of machinery certainly accentuated the evil.

The Factory system was inaugurated, as already shown, under the ancient motive-power of water. The result was that factories were constructed on the banks of many mountain streams in Yorkshire and Lancashire. As the mills and factories were thus situated at some distance from the centres of population, it was necessary toimport labour. "The millowners collected as apprentices boys and girls, and youths and men, and women of all ages. In very many cases no provision adequate, or even decent, was provided for their accommodation. The hours of labour were excessive. The ceaseless and untiring agency of machines kept no reckoning of the exhaustion of human nerves. The Factory system had not been many years in operation when its effects were seen. A whole generation were growing up under conditions of physical degeneracy, of mental ignorance, and of moral corruption."2 The parish apprentices were sacrificed in the most appalling manner to the new demand for labour. They were packed off by waggon and barge-loads to the mills from all parts of the country. They were handed over to their masters, usually without the smallest

${ }^{1}$ See History of Factory Legislation. B. L. Hutchins and A. Harrison. Chap. i.

2 The Reign of Law. The Duke of Argyll. p. 384. 
regard to their welfare, or the conditions under which they were to labour. The predominant object of the "Parish" was to get rid of them as cheaply as possible, and to remove them to a distance on grounds of "settlement." These wretched apprentices were wholly uninspected and doomed to unlimited hours of toil, and it is not surprising to find that " the majority dropped almost mechanically into the ranks of pauperism and crime." 1

An outbreak of an epidemic disease, which committed great havoc amongst the children employed in the factories around Manchester, did much to enlighten the public and to arouse a feeling that steps should be taken to regulate child labour.

Sir Robert Peel, himself a master manufacturer, was the first to take advantage of the growing realisation that legislative action was necessary, and introduced a Bill, with the object of interfering by law with the effects of unrestricted competition on human labour. It is no pleasing reflection that there can be little doubt that the history of the development of the Factory system would have been a less terrible one had the labour which was employed in mills and mines been that of slaves rather than of freemen. A pecuniary value attached to a human being affords him at least some protection.

The Health and Morals of Apprentices Act, which was passed in 1802, as the result of Sir Robert Peel's efforts, marks the beginning of a new epoch in English legislation. A struggle was then re-opened, which is not yet concluded, as to the extent to which State regulation is justified, with regard to the conditions and remuneration of labour. The scope of this, the first Factory Act, was strictly

${ }^{1}$ Report of the Royal Commission on the Poor Laws 1909, p. 619. 
limited to the regulation of the labour of apprentices. It provided that they should no longer be required to work for more than twelve hours a day, and for the gradual cessation of night-work. It further enacted that they were to be instructed in reading, writing, and arithmetic, and to be taken to church at least once a month.

When, owing to the genius of Watt, steam power took the place of water power, a new sequence of events began. It was found to be cheaper to erect the factories in or near the towns in order to secure a full supply of labour. With this change the practice of employing apprentices, who were protected in some degree by Sir Robert Peel's Act, was abandoned, and the evils of unrestricted labour appeared in aggravated form. The custom of employing a large proportion of women and children in factory work increased; their labour was cheap, and parts of the machinery could be fed by almost infant hands. Lord Ashley (who afterwards became Lord Shaftesbury), in a speech upon the Ten Hours Bill, which was before the House of Commons in Committee in 1844, gave figures relating to the factory operatives in five departments of industry in the British Empire, which proved that in the year 1839 a large proportion of the work had passed in to the hands of women and children. In the cotton factories $56 \frac{1}{4}$ per cent; in the silk mills $70 \frac{1}{2}$ per cent.; in the woollen mills $69 \frac{1}{2}$ per cent.; in theflax-spinning mills $70 \frac{1}{2}$ per cent., were women and girls. ${ }^{1}$ What this fact implied in the destruction of home-life, and in the undermined health of mothers, no statistics can measure.

The revelations of the first Report of the Children's Employment Commission on Mines and Collieries, with

1 Hansard. Third series, Vol. lxxiii, p. 1088. 
regard to the terrible abuse of women's labour, indicate perhaps the high-water mark to which the evils of unregulated labour attained. Women "were employed in dragging trucks of coal to which they were harnessed by a chain and girdle, going on all-fours, in conditions of dirt, heat, and indecency which are scarcely printable." 1 Thus they did the work now performed by pit ponies, but under infinitely worse conditions as regards length of hours, ventilation, lighting and safety. I know of no instance of more absolute degradation of "free" labour.

The decay and degeneration of the industrial population was accelerated by the fact that the earnings of little children proved an irresistible temptation to the parents, who recklessly sent them into factories and mines at the tenderest age. The Act of 1802 had no application to this so-called "free" labour, and multitudes of children were offered up at the shrine of the Factory system, without even the small legal protection which that Act could give. Evidence of the length of hours during which they were condemned to work, during the first decades of the nineteenth century in Yorkshire, is afforded by an article in the Leeds Mercury. "In the worsted mills they are employed thirteen hours, with an interval of only half an hour, and in the woollen mills they work fifteen hours, with the interval of two hours for meals ; they were therefore actually at work twelve and a half hours in the former case and thirteen hours in the latter.",2

The law was often flagrantly disregarded even after the passing of the first Factory Acts. An Act of I8I9 prohibited the employment of children of under nine years of

1 History of Fac'ory Lezislation. B. L. Hutchins and A. Harrison. p. 82 .

2 Issue of October 30 th, I 830. 
age, and an Act of 1825 prescribed that no person under sixteen years of age was to work for more than twelve hours a day, exclusive of meal times. In spite of these efforts to protect the children, we find that in some of the Yorkshire villages there were instances of children being employed overtime, and thus working from five in the morning until nine at night, with only an interval of half-an-hour for dinner.

The Report of the Factories' Inquiry Commission of 1832 showed that the manufacturers began to employ children in some rare instances of five years, not uncommonly of six, many under seven, still more were under eight, and the greatest number were under nine years old !1 Boys in the cotton-stocking trade were reported to be working fourteen to sixteen hours a day. Though a minority of the manufacturers made very real efforts to maintain a decent standard of conditions of employment, especially in the newer and larger mills, the reports of the old and small mills were almost uniformly bad. The Commissioners described them as: "Dirty; lowroofed; ill-ventilated; ill-drained; no conveniences for washing or dressing; no contrivances for carrying off dust and other effluvia; machinery not boxed in; passages so narrow that they can hardly be defined; some of the flats so low that it is scarcely possible to stand upright in the centre of the rooms." In the small mills the children were often treated with the greatest cruelty, and were beaten and kicked by the operatives, under whom they worked, and by the overlookers and managers. In the large factories, on the other hand, the Commissioners found that in the great majority of cases the standard was rising, and many
1 p. 15.
2 p. 16. 
proprietors prohibited the use of corporal punishment. The inquiry into the conditions of labour in the mines recorded that children of from four and five years of age were employed in transporting the loosened ore or coal to the horse-paths. The work of opening and shutting the doors was entrusted to the smallest children, who spent twelve hours daily in the dark.

Instances such as the foregoing of the abuse of child labour before the days of factory and mine inspection, and before the introduction of legislation which was in any way adequate to protect the workers, might be largely multiplied. It will, however, be sufficient for our purpose to show what were some of the effects of this hideous theft of the years of childhood on the mental and physical growth of the little factory " hands."

It is obvious that children employed for these abnormal hours had neither time nor strength to devote to learning. Education worthy of the name was an impossibility. In 1843 , some years after the educational machinery of the Factory Acts had been brought into operation, one of the inspectors reported that in the large boroughs of Oldham and Ashton, containing a population of 105,000, there was not one public day school for the children of the wage-earners. In the same year he reported that out of 6,872 children within his district, for whom certificates of school attendance had been obtained, 4,500 were receiving " no education whatever." The descriptions of the factory schools show that they were for the most part a mere mockery. It was stated in an inspector's report for 1839 that among five hundred mills in West Riding there were not a dozen where the education given was really good. It appears that in such schools " the engine-man, the slubber, the burler, 
the book-keeper, the overlooker, the wife of any one of these, the small shop-keeper, or the next-door neighbour with six or seven small children on the floor and in her lap, are by turns found teaching the young idea how to shoot, in and about their several places of occupation, for the two hours required by the law."1

If the effects of the Factory system were disastrous with regard to the intellectual and spiritual development of the children, the influence of excessive toil was likewise shown by their stunted physique and deformed bodies. The Commissioners of 1832 declared that the effects of factory labour on the children were "immediate and remote," the immediate effects being fatigue, sleeplessness and pain: the remote effects being deterioration of the physical constitution, deformity, and the production of "often wholly irremediable disease." 2 They were profoundly impressed with the practically universal evidence as to the weariness which was evinced by the children in their work. The opinions of the medical witnesses as to the results of this fatigue were conflicting, one or two reported that all was well with the health of the operatives in the manufacturing districts, but there is abundant evidence to prove that the over-strain was playing havoc with the general health of the factory population. The Commissioners reported of the North Eastern District of England that they found undoubted instances of children of five years of age being sent to work for thirteen hours a day, and frequent instances of children of nine, ten, and eleven consigned to work for fourteen and fifteen hours daily.

1 Report of Mr. Baker. 1839.

2 Report of the Factorizi Iiquiry Commission, 1832. pp. 25, 31 
The effects which were ascertained in many of these cases were "deformity," and in still more "stunted growth, relaxed muscles and slender conformation," "twisting of the ends of the long bones, relaxation of the ligaments of the knees, ankles and the like." 1 Dr. Sharp of Leeds testified to having seen no fewer than 300 cases of spinal curvature due to protracted standing. ${ }^{2}$

Dr. Loudoun, who was employed by the Commissioners to make a medical investigation in Leicester, Nottingham, Leeds, and Bradford, reported that "children have been worked a most unreasonable and cruel length of time daily, and even adults have been expected to do a certain quantity of labour which scarcely any human being is able to endure. The result of this has been that many have met with a premature death; many have been affected constitutionally for life; and the idea of posterity being injured from the shattered frames of the survivors is, physiologically speaking, but too wellfounded."

Of Manchester Dr. Hawkins reported: "I have never been in any town in Great Britain nor in Europe in which degeneracy of form and colour from the national standard has been so obvious." It is not surprising to find that the physical wreckage of youth resulted in a very early invalidity. A member of the Commission declared that he found it hard to believe the ages of men apparently advanced in years, as given by themselves, so complete was their premature old age. Of I,600 operatives employed in several factories in Harpur and Lanark, but 10 were over 45 years of age; of 22,094 operatives

1 Second Report of the Factories Inquiry Commission, p. 5.

2 Ibid. Medical Report by Dr. Loudoun. p. 13.

3 Ibid., p. 24. 4 Ibid. Report of Dr. Hawkins. p. 3. 
employed in certain mills in Stockport and Manchester, but 143 were over 45 years of age. ${ }^{1}$ Diseases which are especially associated with unhealthy forms of employment, and which the present generation has done so much to check, made their appearance. Among a host of complaints we find that fibrous dust in the cotton and flaxspinning mills produced asthma, which was often followed by consumption. Throstle-spinning of cotton produced diseases of the knee. A form of lameness, known as the "factory leg," was a familiar sight in the manufacturing districts. Lord Ashley, in visiting the hospitals in the manufacturing districts in $184 \mathrm{I}$, noted that scrofulous cases were practically universal ; the wards were filled with scrofulous knees, hips, ankles, etc.; and the sick were almost invariably factory cases. The ill-ventilated mines caused a heavy death-roll of victims, who succumbed to lung diseases resulting from the air being impregnated with coal-dust, and from the unhealthful conditions in which the mining population worked. Dangerous and unprotected machinery was also responsible for a large and unnecessary loss of life, and for the crippling of operatives engaged both in the mines and in many branches of industry.

The insanitary condition of the towns, which sprang up with the rapid growth of mushrooms around the factories, also contributed to the physical degeneration of the working classes. As Sir Robert Peel said, machinery gave birth to a new population. The requirements of this new population rapidly outstripped the housing provision which was made to meet them. Overcrowding in jerry-built cottages was all too common. Typhus was no rare visitant in the narrow, ill-ventilated, unpaved streets, which are described as having sometimes

${ }^{1}$ Lord Ashley: Hansard. Third series, Vol. lxxiii, p. 1083. 
contained heaps of refuse and stagnant pools, in the factory towns of the North of England. It required an epidemic of cholera and a Charles Kingsley to arouse public opinion to recognise in any degree the evil effects of the insanitary towns and homes of the wage-earning classes. That reform in this respect was slow may be shown by the fact that it was estimated at the time of the Cotton Famine that, if the sanitary condition of Lancashire could be made even as favourable as that of the metropolis, there would be an annual saving of some ten thousand lives. ${ }^{1}$

The "truck" and the "cottage" systems also both added their quota to the sum of suffering. Owing to the distance from the towns at which many of the factories had been erected, the custom had arisen, and become widely extended, of the employer acting as both landlord and purveyor to his employees, and paying part of their wages in kind. It was often necessary for him to build the cottages in which they dwelt, and in the absence of any possibility of their obtaining other housing accommodation, he was able to demand any rent he chose. This custom took firm root and was responsible for many abuses. In certain instances foremen kept lodginghouses, and in order to make their business a profitable one, forced even married men who were living in their own homes with their families to pay half-a-crown a week for beds which they did not require. ${ }^{2}$ In the same manner the workmen were often forced to buy the very necessaries of life through their employers or foremen, who thus made the "truck" system one of their regular sources of profit.

1 History of the Cotton Famine. R. Arthur Arnold.

2 Progress of the Working Classes. J. M. Ludlow and Lloyd Jones. d. 260 . 
The worst aspect of this custom was the terrible amount of drunkenness which in certain occupations, more especially in the coal-mining and iron industries, was literally forced upon the men. The employers often made use of contractors or middlemen, who were frequently publicans, to engage their men. A description of the abominable "butty system," as it was named in South Staffordshire, shows the truth of the plea made by the men that if they did not drink, they had little or no hope of obtaining work: "The butty," stated Mr. Tremenheere in the opening of his report on the Mining Districts in 1859 , " is a contractor or middleman between the master and man. He has under him an agent, the ' doggy,' who superintends the work in the butty's absence. It is a complaint of long standing that these contractors and under-agents take advantage of the men in various ways-by stopping money from their wages, which they are obliged to spend in drink; ... by sending drink to the pits in the middle of the week and making the men pay for it, whether they want it or not ; by paying the men late on Saturday night, and keeping them waiting in or about the public-houses in which the butties are interested, in order that they may spend money in drink."

Two further effects of the Industrial Revolution upon the wage-earners require notice as having had an important bearing upon the development of voluntary association throughout the nineteenth century. First, the gulf was increased which divided class from class, and secondly, it introduced an element of unprecedented insecurity into the lives of even the most hard-working artisans.

The "cash-nexus," which Carlyle caustically defined 
as "man's duty to man resolving itself into handing him certain metal-pieces and then shoving him out of doors," was substituted for the old human tie between employer and employed. The new class of capitalist manufacturers in many instances made large fortunes, and operated on so large a scale that they employed hundreds of men who necessarily were individually unknown to them. The workpeople, having no direct interest or property in the goods which they manufactured and obtaining no reward in proportion to the success of the enterprises, began to look upon their employers as mortal enemies rather than as joint-producers. ${ }^{1}$ Animosity between master and man never reached a higher pitch in England, than during the first few decades of the nineteenth century.

The class cleavage which was thus taking place in the towns was also apparent in the country districts. The farmers, who were enjoying increased prosperity, were becoming alienated from their labourers. The high and fluctuating price of corn, the loss of common lands, the appalling evils of an unreformed Poor Law, all cooperated to render the lot of the agricultural labourer a very hard one.

Wages were falling to a point where, as a writer of I 823 observed, no " political alchemy" could induce the labourer to save. "The wages are such as neither to compel the poor to starve, nor to allow him either to waste or to accumulate," 2 was the happy adjustment described in the same pamphlet. The fact that the labourer was chained to his district by the laws of settlement prevented him from seeking to better his condition beyond

1 Industrial Revolution. Arnold Toynbee. p. 73.

2 "Few Observations" published in Pampbleteer, 1823. W. J. Cunningham. 


\section{I34 THE INDUSTRIAL REVOLUTION}

the confines of his own parish. He was demoralised by the Poor Law relief which he was driven to seek by real and palpable distress, and was frequently unable to earn a living wage by even the most strenuous exertions.

Another direct consequence of the rapid expansion of trade was the regular recurrence of periods of alternate over-production and depression. 1 These fluctuations pressed heavily upon the industrial workers. Labour was frequently displaced, and employment was dislocated. Spells of exhausting overtime were followed by dark months when mills were partially shut down, or factories were closed, and employment was for many unobtainable. The time of stress when Lancashire faced starvation, during the Cotton Famine, was prolonged owing to the fact that when the war broke out between North and South America in $186 \mathrm{I}$, the cotton trade had just passed through two years of prosperity, accompanied by extensive over-production. So large was the stock of unsold goods in the hands of the manufacturers, when the first shots were fired at Fort Sumter, that the first effect of the war which stopped the supply of raw cotton, was to bring " relief to the holders of goods, wealth to the speculators in cotton, and a comfortless autumn, with a hopeless winter, to the operatives." 2

Carlyle had many years previously poured forth the vials of his wrath on the new industrial era in which the position of the wage-earner had become so precarious. Of the lives of the cotton-spinners he wrote: "Their trade, now in plethoric prosperity, anon extenuated into inanition and 'short time,' is of the nature of gambling; they live by it like gamblers, now in luxurious super-

1 Industrial Revolution. Arnold Toynbee. p. 71.

2 History of the Cotton Famine. R. Arthur Arnold. 
fluity, now in starvation. Black mutinous discontent devours them; simply the miserablest feeling that can inhabit the heart of man. English commerce, with its world-wide convulsive fluctuations, with its immeasurable Proteus steam demon, makes all paths uncertain for them, all life a bewilderment; society, steadfastness, peaceable continuance, the first blessings of man, are not theirs. . . . This world is for them no home, but a dingy prison house, of reckless unthrift, rebellion, rancour, indignation against themselves and against all men." 1

Such, then, were some of the effects of the Industrial Revolution on the wage-earning class. The whole story of the inauguration of the Factory system, save for the gallant efforts of a few ardent spirits, is a singularly sordid one. Employers and men were driven by forces which they felt themselves powerless to control in to the rushing stream of competition. The manufacturers were engaged in so ceaseless and increasing a competition amongst themselves, that the reduction of hours and the limitation of child labour seemed an impossibility. Many of them honestly felt, and constantly asserted, that the statutory regulation of industry would completely destroy the margin of profits and ruin them. Foreign competition was adding to the intensity of the struggle, and it seemed impracticable to take count of those who fell by the way. It must also be noted that just as the bewildering changes in industrial production were taking place, the country was smitten with a series of disasters which were responsible for some of the misery which we have described. The loss of great colonies, the French War, and a succession of bad harvests, all combined to

1 Cbartism. T. Carlyle. p. 34. 
drain the nation's resources, and to render the task of mitigating the evils a harder one.

Selfishness and indifference on the part of the employers, and the neglect of responsibility on the part of parents, were certainly not the sole causes of the suffering which was inflicted. Men had been taken unawares, and were wholly ignorant as to what measures might serve to reform the all-too-apparent evils by which they were surrounded. Many who realised the terrible condition of much of the factory labour vainly trusted to the operation of the laws of the orthodox political economists of the day to restore the balance. It had yet to be learnt that competition was a force which required control.

It has been wisely said that " time and natural consequence are the great teachers in politics," and this proved to be the case in these critical years of our national life. Natural law was ceaselessly operating to convince men of the appalling results of the disregard of moral law in unrestricted competitive effort. The very evils we have described were teaching the necessary lessons.

In studying the terrible story of sacrificed and maimed lives, we can but reflect that if crime and folly did not bring their natural consequences, if cause and effect were not eternally wedded, mankind would be plunged in utter chaos and a darkness as black as night, in which, though men cried for light, no light would be vouchsafed them. We can but bow our heads in thankfulness for the consistent, faithful and enduring operation of the laws which guide our destiny.

The moral failure of the new industrial world would not have been recognised had it not borne fruit, in results so 
terrible that the conviction was gradually driven home, that the State must either interfere and regulate industry or continue to witness the physical and moral degradation of the wage-earning population throughout the mining and manufacturing centres of Great Britain.

The causes which induced Parliament to intervene and pass the Factory Acts impelled the workmen to combine with a new energy to protect their interests, to insure against the vicissitudes of industrial life, and to cooperate to improve the conditions of their employment. 


\section{CHAPTER VIII}

\section{THE FRIENDLY SOCIETY MOVEMENT}

We have now, while bearing in our minds some of the essential characteristics of the Industrial Revolution and all that the introduction of machinery implied to the wage-earners, to retrace our steps and resume the history of associative effort.

The social reformer whose heart fails him to-day has but to realise the state of degradation of the agricultural labourer and of the factory-workers during the first half of the nineteenth century, to take new courage. The mill grinds slowly, but at least it grinds. There has been a slow, yet persistent, improvement in the condition of the working-classes during the last hundred years. Though there are still rags and tatters in the garb of our civilisation, though a wholly inadequate wage is still paid to no inconsiderable proportion of the manual workers, though mean streets, narrow alleys, and crowded rooms which cannot by any stretch of imagination be called "homes" still dishonour our towns, yet for the higher grades of labour there has been an enormous advance towards material prosperity. For those who may be described as the "aristocracy of labour," low wages, 
insanitary homes, overwork, unhealthful forms of employment have become a thing of the past. A position of relative comfort and economic security has been attained by numbers of workers. Chief among the causes which have contributed towards this steady advance has been the enormous development of voluntary associative effort, which has marked the progress of the nineteenth century. The working-classes have struggled with a vigour and an initiative, which have not been equalled in any country of the world, to work out their own salvation.

It is interesting to recall that the German Socialist, Engels, when he visited the manufacturing districts of England in 1844, prophesied that revolution was inevitable and imminent. He despaired of any peaceful solution of the problem of the adjustment of the "rights" of Capital and Labour. He failed in his diagnosis through not understanding the essentially law-abiding character of the Anglo-Saxons. He did not reckon with the common-sense, determination, and perseverance which guided them to adopt methods for bettering their condition, which were productive of results far more stable and enduring than would have been gained by attempts to overthrow the social fabric by violence.

The associative energy which was exerted by the rising democracy was directed into three main channels. The members of the Friendly Societies and the inspirers of the Co-operative movement strove to raise their standard of life by purely peaceful means. The first endeavoured to provide against various contingencies by developing a system of mutual insurance, the second initiated new forms of democratic distribution and production, primarily in the interests of the wage-earners as 


\section{I4O THE FRIENDLY SOCIETY MOVEMENT}

consumers. The Trade Unions wrestled in a sterner struggle to better the conditions of work for their members, within the limits of the existing industrial system.

These three movements must be regarded as wholly distinct, though running upon parallel lines. They have served to supplement one another, and each has played an important part in raising the whole standard of working-class life.

My object will be to trace the development of these three forms of associative effort from their sources, and to endeavour to describe the part which they have played in national progress.

\section{RISE OF THE FRIENDLY SOCIETIES}

Considerable obscurity still surrounds the origin and early days of the Friendly Society movement. Unfortunately numbers of the documents which would have thrown light upon the history have been destroyed. Many endeavours have been made by the Friendly Societies to prove for themselves an ancient lineage, and romantic indeed have been some of the theories advanced by their members as to their mythical origin. As a writer on the subject has said: "Freemasons stop at Solomon, but Druids go back to the builder of the Ark, Free Gardeners to Paradise, and Oddfellows may, with more reason, claim Adam as the primary head of their Order; while the Foresters, although originally dwellers in Eden, court popularity under the guise of Robin Hood, Will Scarlett, Little John, Friar Tuck and Maid Marian."'

1 The Friendly Society Movement. J. F. Wilkinson. p. 5. 
It can serve no useful purpose, however, to attempt to theorise in the present volume with regard to the prehistoric period of the Friendly Society Orders ; we must content ourselves with remaining on the sure ground of ascertained fact. It suffices to realise that the Spirit of Association is ever-living, and both its traditions and influence are passed on from generation to generation. Whether Freemasonry or other forms of united effort had a direct share in the actual origin of Friendly Societies or no, it is apparent that all manifestations of the impulse to combine have a tendency to influence the associations of successive ages. An echo from the past is often to be found either in some initiation ceremony, or in the emblems, or the persistence of some custom. There is no doubt that the early Friendly Societies and Trade Unions both adopted and adapted for their use much of the ritual and many of the symbols and degrees of the Ancient Fraternity of Freemasons.

Daniel Defoe was one of the first to advocate the foundation of institutions of the nature of Friendly Societies. In his Essay on Projects, written in about the year 1692, he urged that societies should be " formed by mutual assurance for the relief of the members in seasons of distress." He proposed to establish one for the support of destitute widows as an experiment. With rare faith as to the ultimate possibilities of the scheme which he thus urged, he held out the hope, which has been the illusive beacon of Friendly Society workers for the past two centuries, that by further developments of the means of mutual assurance it should be finally possible to prevent " the general misery and poverty of mankind, and at once secure us against beggars, parish poor, alms-houses, and hospitals; by which not a creature so miserable or so 


\section{I42 THE FRIENDLY SOCIETY MOVEMENT}

poor but should claim assistance as their due, and not ask it of charity."

Defoe was not, as has sometimes been stated, the originator of the Friendly Society Movement. Though the subject has up to the present time been but imperfectly explored, there is evidence of the existence of associations of the nature of Friendly Societies as early as the first half of the seventeenth century. In the preface to the rules of the Beneficent Society in Borrowstounness, founded in $178 \mathrm{r}$, it is stated that early in the seventeenth century, "Bo'ness was an important trading port, and that at an early period its inhabitants formed Friendly Societies." A mention is made of the "General Sea-box" instituted in 1634, and the "Landsman's Box," which dates from 1659. ${ }^{1}$

The Scottish Hospital in London grew out of a "Scottish Box" which was instituted by Scottish traders and craftsmen in London during the Great Plague of 1665 . The society performed the useful work of burying more than three hundred poor Scots, and also maintained others in sickness.

These early associations were very commonly known by the name of "boxes." The name originated in the custom of keeping the contributions of the members in substantial boxes or chests, which were often, as in the case of the seamen's chest at Chatham, which was founded by Sir John Hawkins and Sir Francis Drake, locked with several locks, the keys being entrusted to the guardianship of various members. The old name lingered on for a time in the cow-clubs of the Border counties, and in the burial societies of Durham, which

1 Contemporary Review, April, 1873 : Gilds and Friendly Societies. J. M. Ludlow. p. 741. 
were respectively known as "Cow-boxes" and "Lifeboxes."

During the last half of the seventeenth century many of the Huguenot refugees who fled from France in fear for their lives after the revocation of the Edict of Nantes made their way to London. They settled in Spitalfields, and there practised their trade as silk-weavers, and gave a strong impulse to the Friendly Society movement by uniting themselves into associations which endured for several generations. They founded the earliest traceable London Friendly Society in Bishopsgate in 1666, which remained in existence for nearly two hundred years. The descendants of these refugees long maintained their connection with the association, as is shown by the number of names of Norman origin borne by the members. The Society of Lintot, for instance, which was founded in 1708, had, for over a century, successive secretaries of the name of Levesque. From the rules of the society it appears that the qualifications for membership were numerous. The applicant was required to be a member of the Church of Lintot, and "well-intentioned towards good Queen Anne." Mutual help was a prominent feature in the work of the society, and a member, though having no claim for relief during the first year of membership, was assisted by a collection being made for him if he fell sick.

Sir Frederick Eden, in his great work on the State of the Poor, has afforded a considerable amount of information, which he collected upon his tour of investigation throughout the country, with regard to the Friendly Societies of the eighteenth century. From his book we may gather that the associations of this period were mainly small clubs, which met at the village ale-house. Their objects 


\section{THE FRIENDLY SOCIETY MOVEMENT}

were in a large measure social and convivial. It is significant that the first Act which was passed for their encouragement designated them as, "Societies of goodfellowship," and such in the main they were. The members frequently held an annual feast, Tuesday in Whitsun week being a favourite day, on which they celebrated their existence. The members were expected to appear " decent and clean and not disguised in liquor." As with the Gilds of old, they usually met in the morning and made their way to church, where a sermon was preached which was suited to the occasion.

Assistance was very generally afforded to members during periods of sickness and distress by these early Friendly Societies, but mutual help was not their primary object, definite schemes of insurance had yet to be developed. The "box," however, was a useful institution, and by its means many a member was tided over a period of misfortune. It was also the means of obtaining some glimmering knowledge of the probabilities of sickness which was ultimately to develop into the science of vital statistics. The rules of the United Friendly Society of Kirkby Lonsdale contained one very noticeable point, which is indicative of a realisation that members engaged in certain occupations were liable to make heavy claims upon the funds of the society, and they were therefore excluded. "Fire-guilders, dead-white painters, miners, bailiffs and bailiffs' followers," were not admitted on the grounds of the danger to health, or of accident, or, perhaps in the case of the two last-named, the unpopularity incidental to their calling.

The rules of the early societies of Newcastle-on-Tyne, which are preserved in the British Museum, prove that the members insured themselves against the dangers 
which beset seafaring men in the days of the press-gang and piracy. Regulations such as the following appear with some frequency: "If any member shall be taken by a foreign enemy in time of war, or by any pirate in time of peace and imprisoned, the sum of $6 \mathrm{~s}$. per week shall be paid to his wife . . . and if any member be impressed into His Majesty's service, his wife and family shall receive two shillings and sixpence per week during the time he is in such service."

Indications are to be found among these eighteenth century rules that malingering was a danger which had to be carefully provided against. In the solemn declaration required of the applicant on his admission to the Loyal Union Society of Lancashire, he was made to promise to preserve his independence, as far as in him lay, in the following words: "I do declare that I will not complain of sickness, so as to be troublesome to the box, without a just cause ; and if it should please God to visit me with sickness or lameness, which obliges me to have recourse to the box for support, I will, to the best of my judgment, use the best means possible to regain my strength; and, as soon as it shall please God to give me health and strength, so as to become capable of following my business or occupation, I will immediately declare off the box."

A Friendly Society of Newark took vigorous measures in cases of suspected malingering, and sent a surgeon or apothecary to examine the man whose sickness or lameness was thought to be feigned, and if such was proved to be the case he was forthwith expelled from the society for his fraud and imposition.

There is evidence to show that the two affiliated societies-the Oddfellows and Foresters-which were 


\section{I46 THE FRIENDLY SOCIETY MOVEMENT}

to lead the van of progress in organised thrift, came into existence during the eighteenth century. Spry, in his History of Oddfellowship, gives the minutes of the meeting of a Lodge of that society which was held on March 12th, 1748. The Order was at that date well established, for "the meeting opened in its usual form." At least two Orders of Oddfellows were in existence before the close of the century-the "Ancient" and the "Patriotic." They differed, it is said, from one another for a time on a question of deep political importance. The King, when toasted, meant to the members of the one Order, King George, to the other " the King over the water." These early Orders of Oddfellows were secret societies, and admittedly founded upon the pattern of Freemasonry. They retained masonic features in their observances for many years. The letter of a corresponding secretary of the Order in 1820 is interesting as showing the continued use of the secret signs. The writer stated: "We have instances of past officers in possession of all the signs, grips and other secrets and tokens, who have so far forgot themselves as to expose or give them for the vile purpose of imposition."1

No little "pomp and circumstance" was maintained by the brethren in those early days of Oddfellowship. Among the existing records a description may be found of the arrangements which were made for an elaborate church parade which was to be held in June, 1815. It was decided that: "The death supporters carry drawn swords, and be attired in gowns and caps; that none but death supporters and tylers walk in gowns and caps during the procession; that every brother appear

1 A Century of Oddfellowsbip. R. W. Moffrey. p. 26. 
in a white napkin and white stockings, also a white apron with the following binding: Past and Present Grands, scarlet sash with mazarine blue rosette on the shoulder and tied with mazarine blue; mazarine sashes to be tied with sky, sky sashes to be tied with mazarine."1

The meetings of these early societies were probably at times of a somewhat political character, and it is said that Wilkes and Sir George Saville both frequently attended the gatherings of the brethren in order to denounce the Government. It is important to realise that the Orders were in these, their early days, in no sense provident societies at all. The relief which they afforded was merely given in the form of "sick-gifts." The members met for social and convivial purposes, and doubtless, with ready sympathy, raised occasional contributions for the benefit of their sick brethren.

The rise of Forestry is shrouded in mystery, but tradition has furnished romantic tales; and the symbols and ceremonial of the Order have for generations served to recall the legendary connection with Robin Hood, Friar Tuck and Little John.

The Presidents of the Courts, of the Districts, and of the High Court are yet known as the Chief Ranger, the District Chief Ranger and the High Chief Ranger. Forest life is still recalled in the ornaments and emblems. Many of the symbols and ceremonies connected with the initiation and the funerals of Foresters have, however, disappeared during this more prosaic age. The curious initiatory ceremony, when the "stranger" seeking election was given a stout cudgel with which to prove that "he was possessed of a bold, valiant and enterprising spirit," by engaging in combat with any "worthy brother"

1 A Century of Oddfellowship. R. W. Mofirey. p. 22. 


\section{THE FRIENDLY SOCIETY MOVEMENT}

whom he cared to select as antagonist, was abandoned in 1843. The long prayer which opened with the fine invocation: "O Thou Eternal and Supreme Being, whose power is manifested unto man in the whirlwind and the storm, when the rushing winds howl through the forest and the affrighted deer flee, they know not whitherward, from their coverts; when the rain descends in torrents, and the mighty waves in wild commotion lash each other" etc., has also disappeared from the ritual. ${ }^{1}$

The earliest reliable information relating to the Order is to be found in the existence of a list of members belonging to "Court No. I" in the parish of Leeds which was made in the year 1790. It is interesting to recall that a branch of the Order was founded for women in the New Forest at about the same date. It is, however, to be feared that, owing to the repressive action of the Legislature, which we have now to consider, the greater part of the early information relating to the Orders of Foresters and Oddfellows has been irretrievably lost.

\section{FRIENDLY SOCIETIES AND THE LEGISLATURE}

At the close of the century the Government of the day effectually checked any efforts on the part of the Friendly Societies towards federation. Stringent laws were passed, owing to the development of some secret political societies, which placed the most serious difficulties in the path of associative effort. The Corresponding Societies Act ${ }^{2}$ of 1799 dealt a severe blow to the Affiliated Orders. It rendered illegal the existence of any association

1 Historical Sketch of the Ancient Order of Foresters' Friendly Society, pp. x. xi, by T. Ballan Stead and J. Lister Stead.

239 Geo. III, c. 79. 
which was composed of divisions or branches, or of different parts, and which possessed any distinct president, secretary, treasurer or delegate. The punishments for forming any such unlawful confederacy or combination ranged from two or three months' imprisonment to seven years' transportation. The only associations which were not brought within the scope of this law were the existing Lodges of Freemasons. The Seditious Meetings Act $^{2}$ of 1817 went even further, and applied this law to all societies of which members should "take any oath, or take, subscribe, or assent to any test or declaration not required or authorised by law." This was indeed a revival of the tyrannical spirit which inspired the laws of Charlemagne, and the new legislation resulted in some of the village Hampdens who formed associations being sent as convicts beyond the seas to Botany Bay. It was panic legislation, and was passed in consequence of the great social upheaval which Europe had just witnessed in the French Revolution. The governing class of England seems to have existed for years in serious dread of regicides and democrats, who would, it was thought, if given the opportunity to plot and to combine, overthow both altar and throne.

The effect of these laws on the rising Friendly Societies and Trade Unions and the working classes generally was very serious. The associations were driven to secrecy, all traces of the Lodges as branches of their Orders were lost, old books and records were buried or burned, meetings were often held at night to avoid surprise or detection, and minutes of the proceedings were rarely kept. The dearth of information which exists respecting the early development of the

157 Geo. III, c. 19. 


\section{I5 THE FRIENDLY SOCIETY MOVEMENT}

Orders and societies is largely due to the secrecy which was thus forced upon their proceedings. The bitter class feeling which existed during the first half of the nineteenth century was in no small degree the direct result of the keen sense of injustice under which the wage-earners, who were striving to combine, laboured after the passing of these Acts.

The English middle-classes warmly supported these government measures. Francis Place, the famous master-tailor whose tireless efforts were largely instrumental in securing the repeal of the Combination Laws, wrote in $184^{2}$, when the freedom to combine had been won: "Infamous as these laws were, they were popular measures. The people, ay, the mass of the shop-keepers and working people, may be said to have approved them without understanding."

Though the work of consolidation and federation among the Friendly Societies had thus received a severe check, and affiliated associations had been rendered illegal, the first Act which recognised the existence of the Friendly Society movement had been placed on the Statute Book, at the instance of Sir George Rose, in 1793. This Act provided the societies with some relief from taxation, and it also enabled them to settle their own disputes by arbitration, without going before the Courts. In return for these privileges such societies as desired to be registered were required to come forward openly with their rules, which were exhibited to the Justices in quarter sessions and publicly recorded. The property was in future to be vested in certain officers -the treasurers or trustees. It is evident that this law met a real need, for a vast number of small societies were immediately enrolled. In Middlesex alone nearly a 
thousand Friendly Societies sprang into being immediately after the passing of the Statute.

From this time forward Parliament began to pay considerable attention to the question of the regulation of Friendly Society effort. Many of the societies were emerging from the first stage when the mutual help which they afforded was merely of a charitable nature. They were arriving at what may be regarded as the experimental and most difficult period of their existence. They were almost unconsciously drifting into a new position, and the "sick-gift" was becoming a "sickclaim." A scientific basis, upon which to build any system for meeting the claims, had not yet been found, consequently instability was well-nigh universal. Many complaints were made throughout the country against various Friendly Societies, for their insolvency, premature dissolution, mismanagement or dishonesty. This period of instability was inevitable. The necessary experience had to be dearly bought. The societies had in fact undertaken a task before the machinery was constructed which was required to carry it out.

When the Friendly Societies renounced the custom of assisting their members by means of a mere levy, and began to undertake the provident work of raising weekly or monthly payments to provide against sickness, distress or burial, their failure was so common that it was a rare occurrence for a Friendly Society to remain solvent for any long period. The main causes of this insolvency were: first, that the members' payment were too small to bear any equitable proportion to the benefits given. This arose in part from the keen competition in which the societies were engaged to obtain members; they underbid one another with dire results. 


\section{THE FRIENDLY SOCIETY MOVEMENT}

Secondly, they admitted their members without making any distinction as to payments with regard to age. The younger members, realising that they represented the lesser risks, frequently withdrew, leaving the older members to dissolve, and formed new societies of their own. Time, however, had its revenge, and the young men were often deserted in the same way in their turn. Hundreds of Friendly Societies thus collapsed from sheer want of plan. ${ }^{1}$ Thirdly, the small size of the membership greatly increased the jeopardy. An epidemic or an accident which rendered the claims unusually heavy was quite sufficient to exhaust the resources of a small club, whereas the time of stress might have been safely weathered had the risk been spread over a greater number of lives. A recognition of this fact was ultimately shown by the Oddfellows, when they united their "Lodges" into groups, and formed "Districts" to equalise the payments of burial money. ${ }^{2}$

Associated with these evils were others which must be noticed as having contributed to the unpopularity into which the Friendly Societies had fallen. They were far too closely connected with the public-houses, and frequently made use of their general meetings for drinking bouts, and only too often provided in their rules for a portion of their receipts to be spent upon liquor.

A pamphlet which was published in 1823 , though expressing the fullest recognition of the potential utility of the Friendly Society movement, gives a very forcible picture of the evil days on which the village clubs had

1 English Associations of Working Men. J. M. Baernreither. p. 230.

2 Provident Societies and Iniustrial Welfare. E. W. Brabrook, C.B. p. 60. 
fallen. The author describes the number of ruined societies, and the brawls and contentions which occurred among the members at their meetings, and points out that the monthly club-nights were too often nights of " privileged intemperance."1

Mr. Justin McCarthy has expressed some doubt as to whether the Legislature has done the Friendly Societies more good than harm, though he fully admits that there was frequent misappropriation of the funds which often produced grave distress among the depositors. ${ }^{2}$ It is, however, doubtful whether they would have emerged as successfully from this period, when blundering and mismanagement were common, without some guidance and protection from the State. Useful spade-work was being performed by many individuals even during this experimental period, in building up the structure of mutual thrift, but the publicity and the regulation which the law required of registered societies served not only to protect the members, but to educate leaders within the movement as to sound methods of effecting insurance.

Dr. Baernreither, a Member of the Austrian House of Deputies, whose English Associations of Working Men, published in 1889, gave a most appreciative account of the struggle made by the Friendly Societies towards reform, showed considerable insight as to the influences which guided the action of the Legislature with regard to associations for mutual thrift. $\mathrm{He}$ described the two opposite tendencies which have been exhibited by those engaged in building up the Friendly Societies. On the one hand, there have been those

1 A Few Observations on Friendly Societies. J. W. Cunningham.

2 Sbort History of our own Times. J. McCarthy. P. 327. 


\section{I54 THE FRIENDLY SOCIETY MOVEMENT}

who, with sturdy independence, have desired to be left undisturbed by State supervision or official interference, whilst on the other hand were many who held the view that the truest hope of progress lay in effective State regulation, supervision and control. ${ }^{1}$ In consequence of these two counter-influences the position taken up by Parliament has been on the whole one of compromise. Legislative action has, prior to the passing of the Insurance Act of I9II, which has entirely altered the situation, been of an enabling and permissive character rather than of a compelling nature. The compulsion which has existed has merely consisted in the fact that registered societies have been bound to comply with certain statutory requirements. The various lines upon which the organised thrift of the working-classes has been developed have resulted hitherto entirely from spontaneous voluntary effort. The law has merely sanctioned the new forms of association and given them certain privileges after they have fought their way into existence. It has also always been optional for a society to seek registration or to remain unregistered, and there has thus been complete latitude for the followers of the two schools of thought to develop the management of their various associations upon the system which has seemed good to them.

The societies which have sought registration have been given a definite legal form and status, and have received unquestionable privileges and benefits in return for their submission to a certain amount of State supervision. In addition to receiving special facilities for the investment of their funds, they have obtained

1 English Associations of Working Men. J. M. Baernreither. p. 232. 
legislative protection in cases of fraud. The Friendly Societies, before they were brought under the ægis of the law, were liable to be plundered and robbed by unprincipled secretaries or officials with comparative impunity. By becoming legally enrolled they were enabled to remedy this defect, and to obtain proper redress if their funds were dishonestly appropriated. It is important to note that registration afforded no guarantee of the permanent stability of any society, or that its system of insurance was based upon sound financial principles. Parliament wisely left this important matter to the integrity and the growing intelligence of the members themselves. ${ }^{1}$

It is a remarkable fact that though the Affiliated Orders were not recognised in any way by the law until I 846 , they have thrown the weight of their great influence on to the side of those advocating State regulation, and have done much to urge and to promote legislation. It is not my purpose to describe in full detail the measures which Parliament has passed with regard to the Friendly Society movement, but it is necessary to sketch briefiy some of the steps which have been taken to build up the structure of the law which exists at the present time.

It was required, as I have already shown, by Rose's Act of 1793 , that the societies which sought registration should present their rules before the Justices of the Peace. The local magistrates were ill-equipped to judge of the soundness of the schemes for mutual insurance thus laid before them. This was evidently recognised, for an Act of I819 (59 Geo. III, c. 128) made a substantial

1 A Manual for the Use of Friendly Societies. C. Hardwick. p. I 57 . 


\section{I56 THE FRIENDLY SOCIETY MOVEMENT}

alteration and required them " not to conform and allow any tables of payments or benefits, or any rules dependent upon or connected with the calculation thereof," unless they were satisfied that the tables and rules were such as had been " approved by two persons at the least, known to be professional actuaries, or persons skilled in calculation." This praiseworthy effort proved an utter failure. The statistical knowledge required to ensure stability and solvency was not yet in existence, and the Justices, it is stated, frequently contented themselves with obtaining the certificates of the village schoolmasters.

The frequent failures of the societies continued to engage public attention, and in 1825 a select committee of the House of Commons was appointed to examine the whole question. The result of the evidence which was taken and of the recommendations of the committee was that an important Act (10 Geo. IV. c. 56) was passed in I829. The chief provision made was for the establishment of a central authority for registration. In future the transcripts of all rules of societies desirous of coming under the Act were to be submitted to a barrister-at-law appointed for the purpose of examining them. It was also required that every society should, after its rules were certified, in addition to submitting to an annual audit, and presenting its accounts to the members, send a return of its experience every five years to the barrister, who should lay the returns before Parliament. This was a valuable provision in that it ensured the collection at a central office of a large amount of information. To encourage correspondence with the barrister in question, it was enacted in 1834 that letters should be delivered to and from him without charge. This was an important 
concession before the days of Rowland Hill and the Penny Post. ${ }^{1}$ One duty after another was added by Statute to the functions of the barrister, and in 1835 and 1836 Loan Societies and Benefit Building Societies were brought within his sphere of influence.

By an Act of 1846 (9 and Io Vict. c. 27) it was provided that the barrister was in future to be styled the Registrar of Friendly Societies, and was thenceforth to be appointed by the National Debt Commissioners, and to receive a regular salary in the place of payment of fees. This Act is also important as containing the famous "Frugal Investment" clause, which allowed societies to be registered which enabled their members "to purchase food, firing, clothes, or other necessaries or the tools or implements of their trade or calling." This opened the door to the rising Co-operative Societies, and the Rochdale Pioneers were registered under this clause. The power of local registration by the Justices was swept away, and the centralisation of State supervision was thus completed. The Clerks of the Peace were required to send transcripts of rules which had been presented to the Justices between 1793 and 1828 to the Registrar. "The result was that a vast mass of documents, most of them parchment enrolments, very unwieldly in shape and size, was sent to him from all parts of the country, and had to be registered and catalogued by him. The total number of documents appears to have amounted to about 30,000-20,000 rules of societies and 10,000 amendments of rules-so great, even at that early date, had been the progress of Friendly Societies."2 This enormous quantity of records afforded valuable material from which

1 Provident and Industrial Welfiare. E. W. Brabrook, C.B. p. 10.

2 Ibid. p. T5. 


\section{THE FRIENDLY SOCIETY MOVEMENT}

information could be obtained, and useful deductions might be drawn. The stock of information on the subject has been subsequently increased by the issue of the Annual Report of the Registrar since the year 1855 .

From the time when the Registrar was appointed various Acts were passed, adding to and altering his duties, and also largely extending the number of purposes for which Friendly Societies might exist.

In 1870 a Royal Commission was appointed, with Sir Stafford Northcote as its chairman, to inquire in to the law and condition of Friendly Societies. The inquiry made by the Commissioners was protracted and comprehensive. Evils of various kinds, many of which were of a serious nature, were exposed. The beneficent work of well-conducted societies was brought to light, and a large amount of information was laid before the public. The reports of the Commission aroused wide-spread interest and considerable controversy as to the wisdom and necessity of State supervision.

In 1875 , the important Friendly Societies Act ( 38 and 39 Vict. c. 60), was passed, by which some of the recommendations of the Commissioners were carried into effect. The Statute carefully enumerated the numerous purposes for which Friendly Societies might be formed, and brought several classes of societies within the scope of registration, such as cattle assurance associations, and working men's clubs, which had not previously enjoyed the privilege. It gave the members of the societies more ample means for restraining fraud, and provided that upon the application of a certain proportion of the members, the Registrar might appoint an inspector to examine and determine the affairs of any society. The duty of registration was to be vested in a Chief Registrar with 
assistant Registrars under him for England, Scotland and Ireland. It was also provided that returns of sickness and mortality were to be made every five years, and the societies were to send in valuations of their assets and liabilities to the Chief Registrar at the same intervals of time.

It will be seen from this short account of the action of the Legislature, that the means of reform had thus been placed at the disposition of the Friendly Society movement. It remains to describe in another chapter the efforts which were made to grasp the principles of actuarial science, and to place this whole system of mutual aid upon a surer basis. 


\section{CHAPTER IX}

\section{EXPANSION AND REFORM}

While Parliamentary action thus served to give some degree of security and no little encouragement to the Friendly Society movement, the great impulse towards expansion and reform was given by men belonging to the operative class. The Select Committee on the Poor Laws in 1817 , and the Poor Law Commissioners of 1834, expressed the view that Friendly Societies might prove the most potent factor in the promotion of the independence of the working-classes. The preamble to the Act of 1819 stated that: "The habitual reliance of poor persons upon parochial relief, rather than upon their own industry, tends to the moral deterioration of the people and to the accumulation of heavy burthens upon parishes." Men of education devoted both time and energy to furthering sounder schemes of insurance, whereby to raise the people from the dependent condition to which the maladministration of the Poor Law and the industrial changes had depressed them. No enthusiasm, however, for the cause of thrift on the part of the governing classes of England would have secured the success of the Friendly Society movement without the 
driving power which was persistently applied to it, year after year, by the members themselves. Just as the Industrial Revolution was rendering the struggle of the wage-earner a more arduous one, the desire to provide for the risks of life by mutual thrift steadily gained ground. Years of apparent failure, while experience was dearly bought, were the inevitable prelude before the necessary knowledge could be gained and applied. The men who fought for reform were confronted by a problem of extraordinary difficulty, which would have taxed the skill of trained mathematicians. The unsoundness of the position of the Friendly Societies was realised by zealous reformers, while the knowledge of vital statistics at their disposal was almost non-existent.

An indication of the frequent failure of the clubs, and of their members having in consequence to seek parish aid, may be afforded by the evidence given before a Select Committee of the House of Commons in 1849. A witness stated that: "Out of 120 inmates of the Birmingham Workhouse, excluding the young ablebodied labourers, sixty had belonged to clubs which had broken up! Out of sixteen bed-ridden paupers who had belonged to societies of one kind or another, thirteen received no benefits, because the funds of their respective clubs were exhausted. Out of twenty-nine paupers in the Alresford and Winchester Union Workhouse, twenty had belonged to societies which had broken up."1 Obviously the work of reform had yet to be accomplished.

Before attempting to describe the actual steps which were taken towards placing the associations on a sounder financial basis, it will be well to examine some of the more important lines upon which the Friendly Society

1 A Manual for the Use of Friendly Societies. C. Hardwick. p. 82. 
movement has developed from its first and simplest expression in the village club.

The different classes of societies may be roughly divided into three main groups : the Levy Societies, the Dividing Societies, and the Permanent Societies. ${ }^{1}$

1. The Levy Societies. The village clubs and small local societies, of which some description has been given in the previous chapter, commonly adopted the most unsatisfactory system of raising a levy to provide for the expenses of sickness and burial of their members. The tendency of these clubs was merely to last for one generation, for the younger men, as indicated in a previous chapter, naturally wearied of paying levy after levy for their older brethren, before their own need of a " sick-gift" arose, and so frequently withdrew from the clubs, leaving them to be broken up. Many of these societies, as time progressed, entirely changed their form, and adopted graduated scales of contribution and other sound methods of insurance. A number of them have lingered on until the present time, when it appears that the Insurance Act has dealt a death-blow to the large majority of small village clubs. They have been of no little social and educational value, and have borne their share in promoting some knowledge of the principles of thrift, and in fostering a spirit of brotherly kindliness. One element of instability, it must be admitted, has always been present in the composition of these small societies: The membership has not been sufficiently large to insure approximation to average results, with regard to mortality and sickness.

${ }^{1}$ Industrial Assurance Companies, such as the Prudential, are in no sense Friendly Societies, and are therefore not included in this account, though they organise an enormous amount of working-class thrift. 
Consequently, the number of years which such societies have managed to survive has largely depended on the good or ill-fortune which they have chanced to experience. Insurance of a small number of members is a game at hazard, and though every precaution may be taken it cannot be regulated with any scientific certainty. ${ }^{1}$

With a view to obviating this danger some of these village clubs expanded into county societies, and, with the help of the clergy and gentry, who were admitted as honorary members, succeeded in establishing schemes based upon careful calculations. Some of these societies have performed and still perform useful work, but whether the element of patronage was unfavourable to their growth, or whether the rates of contribution fixed upon the advice of actuaries were felt to be too high, they have not succeeded in obtaining as members more than a small fraction of the industrial population in any district in which they have been started. ${ }^{2}$

2. The Dividing Societies, which are also known as "Sharing-out Clubs," Slate Clubs or Tontines, have been built upon the principle of accumulating a fund by means of entrance fees and subscriptions, out of which the expenses of the members' sickness and burials are paid, the surplus remaining over at the end of the year, with the exception of a small sum held in reserve, being divided among the members as a bonus. There has been a considerable prejudice against these societies, and it certainly cannot be maintained that they have served to promote the highest forms of thrift. Certain advantages are, it is claimed, attached to the societies which divide an annual surplus. The margin for

1 A Manual for tbe Use of Friendly Societies. C. Hardwick. p. 124. 2 Provident Societies and Industrial Welfare. E. W. Brabrook, C. B. p. 66 . 
pecuniary fraud on the part of the officers is small, whilst the hope cherished by every member of obtaining a large share of the dividend at the end of the year acts as an effective check against malingering. These clubs have also proved of value as affording sick insurance facilities and savings-banks to men engaged in migratory employments, such as navvies working at the construction of docks or railways. ${ }^{1}$ The disadvantages, which must also be mentioned, are that the tendency for the younger members to desert their older brethren has been exhibited in the same manner as in the village clubs. Some of the dividing societies have been formed by speculating publicans, and too large a proportion of the funds has been consumed in drink. The unpleasing custom of " burying alive," in cases of prolonged sickness, though not as reprehensible as the name would imply, has also served to bring discredit on this form of society. The members have sometimes summarily advanced part of the anticipated death benefit to a sick brother, and then excluded him from further membership. ${ }^{2}$

Strangest of dividing societies was that described by Henry Mayhew, in his book on the condition of the poor of London. While he was making his investigations a beggar gave him a full account of a "Cadger's Club," which was carefully organised in the most approved Friendly Society fashion, with appointed officers, and strict rules against swearing and the use of profane language. One of the objects of the club was to afford assistance to its members when they returned to their brethren after a sojourn in prison. This laudable

1 Englisb Associations of Working Men. J. M. Baernreither. p. 172 .

2 Ibid., p. 173 . 
attempt to provide against the untoward events of life on the part of professional beggars was doomed to sudden frustration, for we read that " the landlord cut away with the funds."'1

3. Among the Permanent Societies may be classed all those forms of Friendly Societies which aim, by means of the regular contributions of their members, to provide sufficiently against certain specified risks. The prospect of success or failure which lies before these societies is determined by the correctness of the calculations upon which the contributions and payments are made, the skill which is shown in the management, and also upon the security of the invested funds.

The problems relating to insurance can only be solved by actuarial science, and by patient study of the law of average. Though it was not until the first quarter of the nineteenth century that the scientific study of vital statistics began in England, the Romans made tables for calculating annuities as early as the second century. They had discovered that there was such a thing as a probable duration of human life, capable of being valued in money. ${ }^{2}$

It was some little time after the fact was realised in England that the law of average was applicable to mortality, that it was found to apply likewise to sickness, and it was even longer before the principle was established that: " the determination of the exact average amount of sickness at every conceivable age, and thereby of the amount of money required to provide against it, is a matter simply of observation and calculation.",

1 London Labour and the London Poor. Henry Mayhew. Vol. I, p. 417 .

2 Gilds and Friendly Societies. Reoiew, April, 1873 .

J. M. Ludlow, Contemporary 
The instinct to strive to make independent provision for the last offices for the dead seems universally to have afforded one of the earliest and strongest impulses towards the organisation of mutual thrift. It is well-known how strong is the feeling, of even the very poor, that it is worth while to make almost any sacrifice to rescue a member of the family from the supposed indignity of a parish funeral. It is a surprising fact to be reckoned with by every relief committee, that even those who have cheerfully acquiesced in a pauper's life for one of their own kith and kin will make the most disproportionate efforts to rescue him from a "pauper's grave."

The result of this powerful impulse is that, of all forms of Friendly Society, the Burial or Collecting Societies have succeeded in attracting by far the largest number of members. They continuously enlarged their borders throughout the last century, and at the close of the year I910 the membership included over seven million persons. These societies practically confine themselves to Burial business, and the contributions are gathered by officers who make a house-to-house visitation. The members are, for the most part, of the poorer classes, and owing to their large number and to the fact that they are scattered over a wide area of country, take little or no share in the government of their societies. The local self-government which is so marked and valuable a feature of the Affiliated Orders is entirely absent. The cost of management of these societies is enormous, frequently absorbing over 50 per cent. of the contributions.

In the early days of the movement serious defects in the management of the Collecting Societies aroused considerable prejudice against them. Mr. Ludlow, 
writing in 1869 , referred to " the rogueries of collectors, the swindling by managers, the bribery and the treachery, the packing of public meetings by roughs, and faction fights," as characteristic of their proceedings. An inquiry into their methods revealed the fact that two general secretaries were each receiving the princely salary of between $f_{5}, 000$ and $f_{6} 6,000$ a year! The system of providing against the great and sudden drain which death creates on the family exchequer need not, however, on account of the mis-management and dishonesty of past methods of insurance, be condemned. The working-classes have shown their real need of these societies by joining them in multitudes. Though Burial Societies do not fall within the scope of the Insurance Act, it is to be hoped that the custom of providing against death will be continued, even though we cannot admit it to be the highest form of thrift.

The Hearts of Oak must be mentioned among the large general Friendly Societies which have expanded from the old village clubs, and which are performing valuable work in the cause of thrift. Societies of this type now conduct their work on a very large scale, and by offering a considerable variety of benefits have attracted an increasing number of members. The business of such societies is transacted at central offices situated in London or other large towns. As there is no local government, the friendly element is almost wholly absent, and the members are personally unknown to one another. Even the most admirably managed of these centralised societies have no small difficulty in checking malingering, which is likely to prove a stumbling block under the present scheme of Government insurance. It is humiliating 
to find that it has been stated, with regard to the Hearts of Oak Society, that if a number of concentric circles were drawn round the office of the Society, it would be found that the percentage of sickness increased in each one in proportion to the distance from the centre!

Foremost amongst the societies which have built up organisations for promoting thrift are the great Affiliated Orders. After the year 1824, when the Combination Acts had been repealed, the Foresters and Oddfellows steadily enlarged their borders, and new Orders were founded. The Loyal Order of Shepherds originated in a small gathering held at an Inn on Christmas evening in the year 1827 , when the motto "Christus noster Pastor" was chosen, and the society determined that one of its objects should be "to proclaim glad tidings to future generations." The headquarters of this society were in the north country-the true home of the Friendly Society movement. For years this association retained a ceremonial symbolic of the shepherd's life, and the brethren attended their gatherings wearing aprons of lambs' wool and large hats. ${ }^{1}$

To this day the Grand Master of the Order bears the dignified title of Chief Shepherd. It is interesting to recall that Mr. Gladstone was admitted as a Shepherd at Hawarden in 1878 , when the solemn initiation charge was read, which contained a fine exposition of the threefold duty of every member of the Order-to God, his neighbour, and himself. ${ }^{2}$

The Ancient Order of Druids claims an earlier origin, and the "groves," as its branches are named, have

${ }^{1}$ English Associations of Working Men. J. M. Baernreither. p. 220 .

${ }_{2}^{2}$ The Friendly Society Movement. J. F. Wilkinson. p. 107. 
benefited large numbers of working men in Lancashire, Yorkshire, and the British Colonies. A kindred Society, the Ancient Order of Romans, was founded in 1833, and having adopted the ancient motto "One for all, and all for one," embarked upon a career of usefulness. The Order of Free Gardeners of Scotland has also developed into a society with a large membership. The Ancient Order of the Golden Fleece, the Order of the Ark, the Ancient Order of Hibernians, the Order of Rechabites, the Sons of Temperance, and the Total Abstinent Sons of the Phœnix all shared in the great work of building up the system which has been a means of promoting the well-being and independence of millions of our countrymen.

\section{VITAL STATISTICS}

From about the middle of last century the Orders began to engage in a struggle towards solvency. The fight was an arduous one against the ignorance and financial superstitions which existed amongst the members.

The Manchester Unity of Oddfellows led the van in the great work of reform. The need was urgent, for though the Society in 1843 was making rapid growth, and members were pouring into the Lodges, instances frequently occurred of designing men taking advantage of the fact that the Order was still outside the ægis of the law, and enriching themselves at its expense. Though hundreds of dispensations were granted annually for opening new Lodges, others were being constantly dissolved, either in consequence of the insufficiency of their funds, or through dividing the funds which they possessed. ${ }^{1}$ Such was the

1 A Century of Oddfellowsbip. R. W. Moffrey. P. 53. 
condition of affairs in the Manchester Unity before Henry Ratcliffe engaged in his great work of preparing the famous "Tables" which were to effect a complete revolution in the views of those connected with the management of Friendly Societies.

Ratcliffe was not the first to enter the field, for some light had been previously thrown on the science of vital statistics by Dr. Price, Mr. Ansell, and Mr. Neison. With Dr. Price remains the honour of having been the first pioneer to explore the subject in modern days. His tables possessed the serious defect that they were composed from the experience of societies which contained a considerable proportion of members whose motive in joining the movement was purely philanthropic, and who therefore made no claim for benefits. Mr. Ansell's observations extended over too insignificant a number of years of life for the results to be of any considerable value.

In I845 Mr. Neison's Contributions to Vital Statistics appeared, wherein he established a number of new and important principles, and vigorously championed the cause of the Friendly Societies. He protested forcibly against the superficial view too frequently taken that they were merely "pot-house schemes," and insisted that by means of the Friendly Society movement the people of England had already begun to work out their own regeneration and independence. ${ }^{1}$

Neison emphasised the importance of distinguishing the returns made from rural, town and city districts, as the rural districts possessed a considerable advantage both with regard to sickness and mortality. He showed that the "expectation of life" in different occupations

1 Contributions to Vital Statistics. Preface, p. xl. 
and trades showed great variations. This point was illustrated in a remarkable manner by a subsequent table of the Manchester Unity. It was found that the average sick allowance claimed by members engaged in the manufacture of pottery during fifty years of life was for no less than 333 weeks, or about seven times as many weeks of sickness as amongst the members who were classified as "clerks and schoolmasters." Neison further wisely urged that societies should be composed of a sufficiently large number of members to realise average results, and he also pointed out the necessity for periodical valuations.

The year after Neison had published his work, Henry Ratcliffe, the corresponding Secretary of the Manchester Unity, began the task of inquiry, to which he devoted the remainder of his life. Three times in twenty-five years statistical collections were made under his superintendence, which surpassed in extent and thoroughness any previous work of the kind. It is noteworthy that during the first three years that he was engaged upon the work he toiled for from fifteen to seventeen hours a day. The entries on each sheet of the tables had to be gone over fifty-eight times, and the trades of the members were classified under twenty-six headings. For this piece of devoted work he received, it is recorded, the munificent sum of fifty pounds! 1

The knowledge of statistics thus arduously obtained, and the weaknesses in the financial position of the Order which were revealed, served to drive home the conviction that it was absolutely necessary to reconstruct the formless benefit associations of the past into soundly regulated insurance societies.

Many writers have followed Ratcliffe, and have

1 A Century of Oddfellowsbip. R. N. Moffrey. p. 65. 
demonstrated the vital importance of developing the Friendly Society movement upon the lines which his investigations had shown to be necessary. But whatever new facts may be established by actuarial science, honour must always rest with the Oddfellows, who contended in the teeth of opposition that it was necessary to know and to face the true facts, and who then courageously placed them at the disposal of the public. The services which were thus rendered to the whole movement were incalculable, and innumerable societies were saved from disaster. Sir Edward Brabrook has pointed out that the very elasticity of contract made by a Friendly Society with its members makes it easy to remedy any defect if only it is found out in time. "Hence the words 'insolvency,' ' rottenness' and the like, which we sometimes hear freely used as describing the general condition of Friendly Societies, are utterly out of place." 1

The work of readjustment, when the necessary knowledge is once obtained and the prejudice which hampers the reformer is overcome, is really a simple one.

The history of the Friendly Society movement from the time that the Ratcliffe Tables were issued is on the whole one of consistent progress, of growing membership and increased stability. The process of reform necessarily involved raising the rate of contributions, and that frequently in conjunction with lowered benefits. It is not surprising to find that these measures were at times strenuously opposed. A circumstance, however, which greatly assisted the societies in raising the premiums of the members, and also enabled them in some cases to meet their deficiencies by extraordinary levies, was the fact that wages were on the whole gradually rising. As

1 Provident and Industrial Societies. E. W. Brabrook, C.B. p. 93. 
the societies gained in prestige an increasing number of small shopkeepers and tradesmen joined them as bona fide members, and took an active part in the work of reorganisation. Willing self-sacrifice on the part of the members, when they had once grasped the necessity for reform, also frequently served to lighten the task.

\section{THE MOVEMENT ABROAD}

While the work of the Friendly Societies in England was thus being established on a sounder financial basis, the movement was rapidly spreading beyond the seas.

Oddfellowship was first established in America as early as the year 1820, when the Duke of York Lodge at Preston granted a dispensation to establish a Lodge at Baltimore. The seed had fallen upon fruitful soil, and in little more than half a century Oddfellowship had made its way throughout the greater part of North America. From thence the brothers in the New World carried its principles to other lands, including Switzerland, Germany and Peru. ${ }^{1}$

The American Order, shortly after its foundation, severed the formal ties which bound it to the parent society, in consequence of a divergence of opinion upon ceremonial matters. The tendency in England, owing to the suspicion with which the Legislature regarded all associations with secret signs, was to simplify the ritual, whereas in America the brethren insisted upon elaborating their ceremonies, and extending their initiatory charges. The Oddfellows Orders of England and America have now but little in common in their observances, though they both retain the use of the ancient watchword, "Friendship, Love, and Truth."

1 The Friendly Society Movement. J. F. Wilkinson. p. Ir5. 
An interesting development in American Oddfellowship has been the institution of the Order of Rebecca and the Households of Ruth, to which the wives and daughters of members are admitted, their duty being to relieve and nurse the sick and distressed brethren. The women receive certain privileges in return for their services. ${ }^{1}$ The American Order has been distinguished for its consistent allegiance to the principles of brotherhood, which remained unshaken throughout the Civil War between the North and South, and for its largehearted philanthrophy: "When fire demolished the city of Chicago, or yellow fever decimated the inhabitants of Memphis, or the grasshopper plague made a desert of the States of Kansas and Nebraska, then the generosity of the Order was shown by gifts of tens of thousands of dollars. ${ }^{2}$

Oddfellowship, after it had gained a foothold in America, made its way to most of our Colonies. In 1840 the first Lodge, named the "Stranger's Refuge," was opened in Sydney, and the society has taken firm root in Australia. Foresters, Shepherds, Druids, and Rechabites have followed the Oddfellows in establishing branches to promote thrift in the Australasian Colonies. Numerous Friendly Societies have been founded in the West Indies, and the report of a recent Commission appointed to inquire into their working may be quoted as illustrating the influence of the Friendly Society movement on colonial life: "The Friendly Societies have played an important part in the life and in the development of our people; they have been a potent influence in promoting their moral and material welfare.

1 The Friendly Society Movement. J. F. Wilkinson. p. 118.

2 Spry's T ext Book, p. 70. 
... A study of the various rules of the Friendly Societies reveals that they consistently aim to exert a progressive influence on the lives and affairs of the members, to inculcate human sympathy, obedience to law, good manners, devotion to dury."1

To follow the fortunes of the movement further, in its extension to foreign lands, would be entirely beyond the scope of this volume. It is, however, important to recognise that the Spirit of Voluntary Association, which is so marked a characteristic of our race, has been of no small service to our colonists in their work of building up the Empire beyond the seas.

THE SOCIAL VALUE OF THE FRIENDLY SOCIETY MOVEMENT

In trying to estimate the value of the vast Friendly Society movement in Great Britain, the first point to be observed is that its aim has not been by any means a purely material one. Though the wise husbanding of resources against an evil day has been of incalculable service in raising the condition of large sections of wageearners from the state of economic insecurity which resulted from the Industrial Revolution, it would be to misunderstand the movement to see in it nothing more than the combined efforts of individuals to relieve themselves by insurance from the most pressing of life's anxieties.

From the days when the members assembled in cheerful conclave in the inn-parlour, and, finding that some brother had fallen sick, raised a sum for his assistance, to the present day, when we hear of Friendly Society members

1 Report of the Cbief Registrar of Friendly Societies. 1912. p. 123. 
sitting up night after night with a sick brother in obedience to the rules of nearly every society in the West Indies, an altruistic spirit has inspired the best work of the whole movement.

Many a society has, it is said, originated in the habit instituted by gangs of men of raising contributions to help some injured or sick brother. The provident association has thus been the direct outcome of sympathy expressed in charitable form. The fraternal sense which has induced men to help their associates has also been shown in the great efforts which Friendly Society members have made to send relief to distant parts of the country, and even to other lands in times of special distress. The Manchester Unity, for instance, sent fio,ooo during the cotton famine to help the brethren who were suffering from the effects of the American Civil War. Again, more recently, when San Francisco was reduced by earthquake to a heap of ruins, the same Order raised a levy to relieve the members of the Californian District.

The most valuable effects of the development of the Friendly Societies have been perhaps the loyalty and self-sacrifice which have been awakened in the members. Men have willingly devoted themselves to untold drudgery in building up their associations and in striving to keep them in good financial order. The remuneration for the clerical and other work has often been merely nominal, and the labour has been willingly given by the members with the sole object of maintaining the societies in efficiency. The value of the self-sacrifice which has thus been constantly manifested is inestimable. If the efforts made by the members of the Friendly Societies have been in no small measure altruistic, the movement, especially 
in the early days of its development, was also definitely religious and moral in its character. The members were expected, as were the Gild brethren of old, to bear good characters, and the ceremonial observances were emphatically of a religious order.

The part which the Friendly Societies have played in the welfare of the State has been a most valuable one, and has been perhaps somewhat insufficiently emphasised. Organised thrift has exercised a powerful influence in preventing men from sinking, through temporary misfortune, into a morass of poverty, and so requiring State relief. The Secretary of the Ancient Order of Foresters stated, in his testimony before the Royal Commission on the Aged Poor, that of the half-million members which constituted that society he could not find that there were as many as a hundred persons who were in receipt of Poor Law relief. The self-respect, the independence of spirit, and the training in habits of thrift, which the whole movement has engendered, have been of the greatest service in diminishing the obligations of the State with regard to relief. The Friendly Societies have also exercised a wholesome influence in promoting peace within the social system. By their means the working classes have secured an important financial interest in the welfare of the country. The possession of large vested funds has given the societies a strong reason for desiring the maintenance of peaceful relations with foreign countries, and also between Capital and Labour in Great Britain.

The societies have also served to educate men in intricate financial questions, and have thus borne an important part in training efficient citizens. The statistical knowledge, which has primarily resulted from the 
efforts of the members, and of those interested in the thrift movement, has served as a searchlight, revealing abnormal rates of sickness and mortality in dangerous trades. The patient study of the law of average in its relation to sickness and death has served to prove that the law is capable of modification by well-directed voluntary and legislative efforts. It has been proved that the eradication of disease, the diminution of vice, crime, war, and extreme poverty, all tend to increase the duration of life, and to lower the claims made by sickness upon the funds of the thrifty. The knowledge, therefore, which an experience of vital statistics has given has served to give the Friendly Society member a keen interest in Parliamentary action. Factory legislation, for instance, which reduces sickness and accident, is a matter which immediately concerns him as a member of a body which insures against both. All local sanitary matters touch him closely. A fouled water supply and a consequent outbreak of typhoid may produce a marked diminution in the funds of his society, and might well ruin it. It becomes therefore a part of his interest as a member of a mutual insurance society that his brother members should be living and working under healthful conditions in their factories and homes. The action of the Legislature and of the municipal authorities is therefore very markedly his affair, in his capacity as a member of a Friendly Society.

The criticism has often been made that the movement has not succeeded in embracing the lower grades of society. It is a well-established fact that men who are living below a certain standard of life and who are deficient in education do not possess the initiative to combine. Where the strain of life presses most insup- 
portably, and where the need for united effort is greatest, the organising power to associate is usually lacking. It is well known to what a small extent women, generally speaking, are imbued with the Spirit of Association, and it is no mere coincidence that in the labour market they are frequently grossly underpaid. It is remarkable, too, how comparatively little they have accomplished in building up Friendly Societies for themselves. It must, in fact, be admitted that voluntary effort in the Friendly Society movement, though much has been accomplished, has failed to cover the whole field of endeavour, and to realise the high hopes of Daniel Defoe. We have, however, yet to see how far the Friendly and allied societies will succeed in permanently holding the members from the lower social grades, which have now been compulsorily brought within the scope of the Insurance Act. The scheme for the deposit contributors under the Act is a significant indication of the recognition of the Government that there are many who are at present incapable of keeping up regular insurance under the Friendly Society organisations, and also that there are a large number of "lives" which no society will accept. Though the Act will doubtless enormously enlarge the field of Friendly Society effort, compulsory thrift will not of itself produce a national regeneration. The allied forces of religion, education, and all that serve to build character, have yet to play a mighty part before the problems which distress and perplex our generation are finally solved. And it must be remembered that compulsory thrift is of infinitely less value in the formation of character than voluntary saving.

If it cannot be claimed that the Friendly Society movement, whilst unaided by State funds, has succeeded in 
inducing the lowest grades of the population to exercise habits of thrift, yet it is beyond dispute that among the forces which served to raise the standard of life in large sections of the working classes during the nineteenth century, was the manifestation of the will of the people to associate in the Friendly Society movement. 


\section{CHAPTER X}

\section{THE CO-OPERATIVE MOVEMENT UNTIL I863}

THE Co-operative Movement, which was one of the three chief means which the rising tide of democracy found of expressing its needs in the nineteenth century, has been extraordinarily complex, both in its aims and methods, throughout the whole course of its development. It may be said to represent, in the main, a protest against the ill-effects of unrestricted competition, and the grinding poverty which arose in the land as the Industrial Revolution made its way.

This protest has expressed itself in various forms. Some of the pioneers of the movement have endeavoured, with greater enthusiasm than wisdom, to bring about the Millennium by advocating and organising Socialist life in communities, while others have striven patiently to better the conditions of working-class life by schemes of an essentially practical nature.

Co-operation includes within its borders attempts to improve the lot of the workers by substituting manufactories directed by the workers themselves, for the Factory system in which industry is controlled by the 
capitalist and the employer, and the Co-operative Store movement which arose in the interest of the workingclass consumer, with the object of enabling him to spend his small wages to greater advantage. The more modern developments of profit-sharing and Co-partnership must also be included, with their great possibilities, in suitable spheres of action, of substituting peaceful relations between the employer and employed for unrest, friction and even active strife.

The vital point to remember in considering the Cooperative movement is that every aspect of it has been primarily inspired by the same motive-a keen desire for social betterment. This has been the secret of its great value as a quickener of conscience. The whole movement has been a struggle to strengthen the position of the weak by employing the forces of associative effort. The same impulse has served to produce both the ambitious schemes for social reorganisation in communities, and the humblest village store. At the present time, when the increased material prosperity of the movement has tended to obscure the highest Co-operative ideals, it is well to remember the aims which actuated the early pioneers.

We recognise in Co-operative industry something more than in the ordinary commercial or industrial enterprise. It bears in its very essence the tradition of a noble enthusiasm which has valued aspiration more than achievement. It has been finely said that: "This inheritance of teaching and example is a great responsibility, and lays those who ignore it open to the ancient offence of sinning against the light." 1

Under the Co-operative banner, men have refused to

1 Co-operative Industry. Ernest Aves. p. 105. 
follow the line of least resistance, they have tackled the most baffling problems, and have often fought their way against a stream of opposition and ridicule. The success which has been achieved is the more remarkable; the failure which has sometimes been reaped has never been valueless.

The success of the movement must, therefore, not be estimated solely by the outward and visible results, but also by its influence in the realm of thought. It has served to enlighten public opinion and to promote saner and more moral views respecting the equitable relationship between employer and employed. Its work in attempting to solve the problem of the respective "rights" of Labour and Capital has already shown markedly good results, and it appears that it is destined to prove a valuable instrument in the process of industrial evolution in the future. We may unhesitatingly accept the opinion of Justin McCarthy that: "Posterity will not let the Co-operative principle die. It has taken firm hold of our modern society. It seems certainly destined to develop rather than fade; to absorb rather than be absorbed." 1

\section{ROBERT OWEN}

In attempting to sketch in barest outline the history of the Co-operative movement, it is well to examine, in the first instance, the energising influence which was brought to bear upon it by the life, work, and teaching of Robert Owen. Though Owen cannot be said to have been the originator of Co-operation, which in its more primitive forms is probably as ancient as industry itself, yet he

1 A Sbort History of Our Own Times. Justin McCarthy. p. 326. 


\section{I84 THE CO-OPERATIVE MOVEMENT}

certainly, during a number of years, supplied its chief inspiration. When the resistless march of the Industrial Revolution was playing havoc with the health, strength, hopes and ideals of the working-classes, he looked around him and saw things as they were; he gazed into the future and his eyes rested on a vision of society transformed.

Whatever view may be taken of the wisdom of his theories, we owe him our lasting gratitude as a nation for denying, with all the force of his vigorous nature, the tenets of the gospel of materialism, and for unflinchingly teaching the doctrine that wealth which did not bring well-being to those engaged in its production was an appalling anomaly. In an age of acquiescence in intolerable hardships to the wage-earners, he was spurred to action by an ardent social faith. He untiringly attacked convention and the complaisant acceptance of a system of industry which was producing a population, stunted both in physical and moral growth, throughout Yorkshire, Lancashire, the Midlands, and the valley of the Clyde. His whole life and a fortune were devoted to attempting to mitigate poverty, and to reconstruct the social system. Robert Southey said of him that he was one of the three men of his generation who gave an impulse to the moral world. Time has served to prove that there was truth in the poet's verdict.

Robert Owen was born in a Welsh village in $177 \mathrm{I}$. He was the son of humble parents, and received but little education save that which he gained by desultory reading. He was first launched into work at the age of ten, as a shop-boy at Stamford. His rise was rapid. He so impressed men with his capacity that at the age of nineteen he found himself, to his great surprise, entrusted with the superintendence of a cotton mill at Manchester. 
His energy and business aptitude were shown by his close attention to the processes of manufacture, and his factory soon became famous for the fine quality of the cotton woven by the newly-invented machinery. The condition of the workpeople at once enlisted his sympathy. He did not, however, find an opportunity for embarking on any scheme of social reform until 1800 , when he was made managing partner of an important industry at New Lanark, which employed a large number of hands.

In his Autobiography, Owen has given a graphic description of the industrial village in which he found himself. The factory had been first worked by waterpower, and was situated in a country district A house had therefore been built to hold 500 apprenticed workhouse children of but six, seven and eight years of age, who worked from six in the morning until seven at night. Some perfunctory attempts were made to educate their exhausted minds at the close of the factory day. The young manager was horrified by the conditions in which the weavers lived, by their lack of education and intelligence, and their low standard of morality. He instantly set to work, with the zeal of the true philanthropist, to devise " a new system of management on principles of justice and kindness, and gradually to abolish punishment in governing the population." His colleagues were alarmed by the schemes which he devised, and in order to have a free hand he made arrangements with new partners, and obtained absolute control of the mills in 1814 . From that year he rapidly proceeded to put his ideas into execution. He provided a free education for all the children from infancy. He built good cottages and organised amusements for the workpeople. He 
reduced the hours of labour from seventeen to ten a day, he raised wages and ceased to employ children under the age of ten. He also thoroughly reorganised the village, and closed some of the drinking bars. He discovered that one of the chronic sources of poverty was the miserable quality of the goods which were obtained from the small shops in the village, and he therefore provided a store, at which the factory "hands" could satisfy their requirements at little more than cost price, which served to increase greatly the real value of their wages. The small margin of profit which was made at the store was devoted to educational purposes. This may be regarded as an anticipation of the custom which is followed by modern Co-operative societies of the present day, of giving a fixed percentage of their profits to educational work.

These experiments encountered every kind of opposition and prejudice. Owen's fellow-employers regarded him as a hare-brained enthusiast, whose financial ruin was assured. Many of his contemporaries looked upon him as a mere visionary, and he was undeniably a seer of visions, and a dreamer of dreams. At the same time he was endowed with remarkable business sagacity, and his Quaker partner, who wrote to him: "Robert Owen, thou makest a bargain in a masterly manner," laid his finger on one of the secrets of his success. It is recorded that the only time that Jeremy Bentham ever made money was when he was in partnership with Owen! The result of this business acumen was that, within a few years, the balance sheet of the New Lanark cotton mills furnished the best possible answer to the criticisms levelled at the new system of providing for the physical and moral welfare of the factory hands. After twentynine years of work Owen was able to write that during 
that period " we did without the necessity for magistrates or lawyers ; without a single legal punishment ; without any known poor's rate; without intemperance or religious animosities. We reduced the hours of labour, well educated all the children from infancy, greatly improved the condition of adults, diminished their daily labour, paid interest on capital, and cleared upwards of $£ 300,000$ profit."

The explanation of this financial success was that Owen had discovered a new source of wealth in the willing co-operation of his workpeople. He had earned their affection and respect, he had cultivated their intelligence, and had improved both their physique and their skill. The result of this attention to "vital machines," as he put it in his famous appeal to manufacturers, was that Capital and Labour worked together in a new harmony. $\mathrm{He}$ thus proved to the world that oppression, long hours, all that may be summed up as "sweated labour," were not sound business, and discovered the fact, which is now accepted as axiomatic in many classes of industry, that well-paid efficient labour is the cheapest in the end.

Owen was not content with bettering the condition of those for whom he was immediately responsible, he also schemed for a world-wide reconstruction of society. The chief tenet in his social faith was that mental and physical environment were infinitely the most important factors in individual development. He regarded man as the creature of circumstance. He therefore argued that it was within the power of employers and the Government, " to form the character of their dependents by placing them in healthy, moral and enjoyable surroundings." Hence he regarded education as the master-key 
to the social problem. His belief in the reforming power of State regulation was limitless. He even asserted that : "Any general character, from the best to the worst, may be given to any community by the application of proper means, which means are to a great extent at the command and under the control of those who influence the affairs of men."

In order to attain the Utopia of his desire, he believed that it was necessary to sweep away the existing competitive system. This he hoped could be accomplished without the aid of revolutionary methods. His belief was that the application of his principles would create a new wealth for the poor, and that an entirely peaceful readjustment was therefore possible. Individual ownership was gradually to cease, all things were to be held in common, in the new heaven upon earth which his imagination projected. Above all, profit was to be exterminated. He regarded profit as the main cause of poverty, oppression and industrial warfare.

The equitable exchange of commodities between various groups of associated workers was to be substituted for competitive trading, with its essential characteristics of alternating periods of inflation and depression. "Unrestrained Co-operation on the part of all the members, for every purpose of life " was the method whereby to redeem society, which he enunciated in the Economist of August 27th, 1821. How such radical changes were to be made, in spite of their inherent impracticability and of the hostile attitude of a capitalist governing class, he never fully explained.

It is not necessary to our purpose to examine further Owen's social philosophy, or to describe his numerous 
experiments, such as the communities of Ralahine, Queenswood and Orbiston, or the fantastic labour exchanges. Time, the great winnower, divides the chaff from the grain. All that was noblest and most valuable in Owen's teaching is bearing and will, we believe, continue to bear fruit. Much that was crude, unbalanced and immature will pass into oblivion.

$\mathrm{He}$ had the defects of his virtues. His ardent faith in his own schemes, his dogmatism and a certain arrogance, blinded him to the facts which controverted his theories. As Harriet Martineau said of him, he was unable to distinguish between assertion and argument, and this characteristic habit of mind weakened the force and destroyed the balance of his writings. He almost ignored the fact that nature equips her children very unequally for the race of life. He was blind to the testimony which his own life's work afforded. Environment had fitted him to live and die a small trader. His own inherent qualities slew the shopkeeper in him, and made him a leader of men. He failed to see that competition, within due limits, is a necessary guide to direct energy into serviceable channels, and a valuable incentive to man in his present condition, to do the best that lies in him, and is therefore an important factor in individual development-"a force to be used, not to be blindly worshipped." $\mathrm{He}$ made the profound mistake against which Charles Kingsley protested, of imagining that men's hearts can be changed by Act of Parliament.

The chief value of his teaching consists in the fact that he drove home the great truth that co-operation is a living force, and also that where it is manifested on wise lines it is economically valuable. He rightly insisted that the mere acquisition of wealth was of small 
importance compared to the growth of " the higher moral life in which all things are subordinated to a sense of duty begot of universal brotherhood." To judge his life's work merely by his theoretical writings and his practical failures is to estimate it unfairly. His influence upon the thought of his age was very great. His exposition of the "New System of Society" had a remarkable effect upon the rulers of his day. He was consulted by kings and ministers of many parts of the world, and numerous European statesmen visited New Lanark to judge for themselves of the success of his notorious experiment. His influence helped to secure the passing of the Factory Act of 1818 . He proposed a system of free and compulsory education, and he advocated the foundation of free libraries. It is not too much to say that much of the progressive legislation of the nineteenth century was the outcome of the life's teaching of the fearless thinker, Robert Owen.

\section{THE FIRST CO-OPERATIVE MOVEMENT}

With the fullest acknowledgement of the strength of the impulse which Owen gave to the Co-operative movement, we have now to trace its history from the first stages of humble experiment before it was caught up in the "flood-tide of idealistic enthusiasm" of his creation. The earliest Co-operative societies to appear in England were associations of consumers which controlled small flour-mills and baking societies. They were started as a protest against the exorbitant charges which were made by the local mill-owners. The millers possessed what almost amounted to a monopoly of their trade, which became intensified by the conversion of many corn-mills 
into cotton and other factories. ${ }^{1}$ In addition to charging extortionate prices for their flour, they often also freely adulterated it.

In 1795 the Hull Anti-Mill Society was founded by the "poor inhabitants of the town," with the object of building a mill by means of the weekly subscriptions of the members, and of supplying them with flour. The society was so entirely successful that from the year 1800 onwards, several other mills were started on similar lines. One of the first effects of the foundation of these societies at Hull, Whitby, Sheerness and Devonport was that the very force of competition, so despised by the Owenites, drove the old-established mills of the city to amend their ways and to supply their customers with a pure article at reasonable prices.

Robert Owen's influence on the Co-operative movement was first shown in the establishment of Union Shops between 1828 and 1832 . The first trading association of this type was founded at Brighton, and the description of its aims, to be found in the Co-operator, not only foreshadows some of the developments of the Store movement of to-day, but shows that the definite intention also existed of putting the Owenite scheme of social reconstruction into practice. After a certain amount of capital had been acquired by means of the subscriptions of the members and the profits of the business, it was stated that: "The society will be able now to find work for some of its own members, the whole produce of whose labours will be common property ... When the capital has accumulated sufficiently, the society may purchase land, live upon it, cultivate it themselves, and produce any manufactures they please, and so provide for all their
1 The Co-operative Movement.
B. Potter. p. 42. 
wants of food, clothing and houses. The society will then be called a community." 1 These intentions were never realised, and the Brighton society began and ended its existence as a general shop. The movement, however, spread rapidly until 1833 , when there were said to be some 400 Co-operative societies in existence. The main object of these Union shops was to supply the needs of working-men, by buying and retailing genuine articles of food and clothing at wholesale prices. Cash payments were usually insisted upon.

In some instances the Co-operative shops succeeded in commanding so extensive a business that they began to employ their members in the manufacture of clothing, furniture, boots and shoes. The rules exacted a high moral standard of the members. Profane language was commonly prohibited, and persons of immoral character were excluded from membership. The Preston society is said to have been so rigid in discipline that it expelled members who spoke disrespectfully of the goods of the society.

It must be remembered that, as was the case with other forms of democratic associative effort, the law was against these societies at first. Before 1852 they had to creep into recognition under the Friendly Societies Acts, and were forbidden to deal with the outside public at all, and could only legally trade with their own members. Their funds were unprotected, and any dishonest secretary or member could appropriate either goods or money without fear of prosecution.

To understand the success of the movement which was started under such unfavourable auspices, it is necessary to realise the extreme difficulty which the working-class

1 Tbe Co-operative Movement. B. Potter. pp. 44, 45. 
consumer of the period had in satisfying his requirements with sound goods at fair prices. We find that: "The back streets of the manufacturing towns swarmed with small shops in which the worst of everything was sold, with unchecked measures and unproved weights."' The shopkeeper did well enough when he got paid on Saturday nights, but payments were irregular, and there were many bad debts. The consumer who paid regularly had to pay for those who did not. The result was dear, indifferent goods for all, and a chronic weight of debt pressing upon many of the customers.

The period of enthusiastic activity which produced the Union shops was short-lived, and by 1833 the greater number of them had disappeared. It seemed, indeed, as if the whole movement was doomed to perish. During the ten years or so which followed, though Owen's influence was vigorously exerted, and though annual congresses and a constant stream of Co-operative journals and pamphlets were preparing the ground for further advance, Co-operation was driven into the background by the rising of the Chartist agitation, and the battle which was being waged around the growing Trade Unions.

\section{CHARTISM}

When Queen Victoria came to the throne the workingclasses were in a condition of profound discontent. The Reform Bill of 1832 , which had abolished the rotten boroughs and had admitted the middle-class to a share in the franchise, had done little for the working-man, save to intensify his sense of grievance. The discontent was

1 Progress of the Working Class. 1832-1867. J. M. Ludlow and Lloyd Jones. p. 132.

o 
also fanned into flame by the privations caused by a bad harvest, the high price of corn, and by a period of serious commercial depression. A few weeks after the Coronation a Radical meeting was held at Birmingham, and a manifesto was adopted which became known as the People's Charter. Its famous "six points," which were regarded at the time as constituting such revolutionary demands, were: Universal male suffrage, annual Parliaments, payment of Members, vote by ballot, equal representation, and the abolition of the property qualification for Members of Parliament. It is difficult now, when several of these demands have been conceded, to realise the passionate support and repudiation which the Chartist manifesto aroused when it was first formulated. Immense meetings were held throughout the country, and excitement was raised to the highest pitch. The agitation had been carefully prepared. A flood of Chartist literature had issued from the press, and had made a strong appeal to those who were demanding a wider suffrage. The best and the worst elements of democracy flocked to support the cause. Chartists drew within their ranks idealists who led the van of progress, the majority of the hard-working artisans of the manufacturing towns, unscrupulous and ambitious leaders, and a pitiable rabble who hungered for the very means of subsistence. The result was that this heterogeneous army was divided into two main camps. The one consisted of the men who clamoured to enforce their demands by physical violence, the other was composed of those who sought to obtain their end solely by the employment of moral force.

In June, I839, there were serious riots at Birmingham, which followed on the refusal of the House of Commons to consider a suffrage petition. Torch-light meetings 
were held at night, seditious speeches were made. The Government prosecuted some of the orators and leaders, who were imprisoned. ${ }^{1}$

Eight years later, in 1847 , the agitation came to a head, and it was decided to overawe Parliament by a vast display of physical force. A huge procession was to be formed on Kennington Common, and was to march, with Fergus O'Connor at its head, to again present a petition at Westminster. The procession was declared to be illegal, and loyal subjects were forbidden to take part in it.

The story of the famous April Ioth, 1848, is well-known. All London was alarmed that morning by rumours of fierce encounters between the Chartists and the police. The Duke of Wellington, who was in command, barricaded the bridges and Downing Street, garrisoned the Bank of England, and closed the Horse Guards. A vast number of special constables was enrolled. The meeting on Kennington Common ended in fiasco. The expected assembly of 100,000 men dwindled to a mere rabble of reckless partisans and foolish zealots, who were left with thieves, roughs and hobbledehoys " to cheer for the revolution." The great Chartist petition was found to contain a much smaller number of signatures than the leaders had estimated. O'Connor was in favour of obedience to authority, and to conclude the tale in Kingsley's words : "The meeting broke up pitiably piecemeal, drenched and cowed, body and soul, by pouring rain on its way home-for the very heavens mercifully helped to quench our folly-while the monster petition crawled ludicrously away in a hack cab, to be dragged to the floor of the House of Commons amid roars of laughter." 3

1 Sbort History of Our Own Times. Justin McCarthy. p. I9.

2 Cbarles Kingsley. C. W. Stubbs, D.D. p. 99.

3 Alton Locke. 
THE CHRISTIAN SOCIALISTS

Charles Kingsley, who was profoundly moved by the whole episode, rushed up to London from Eversley to see if a collision between the Chartists and the troops could be prevented. Revolution having ended in smoke mediators were not required. The following week, however, a small group of men, realising the intensity of the poverty and the suffering which had fostered the discontent, met to see whether the more revolutionary forces of Socialism could not be guided into a new channel and serve as a mission of industrial peace. ${ }^{1}$ The meeting, at which F. D. Maurice, Archdeacon Hare, J. M. Ludlow, Thomas Hughes, and Kingsley were present, gave birth to the Christian Socialist Movement, which afforded a new stimulus to Co-operation. Self-governing workshops were founded somewhat on the model of the French State workshops of 1848 , but with the important difference that they neither asked for nor desired State support. The English workshops were essentially private associations, owing their existence to the efforts of voluntary reformers.

These workshops of the Christian Socialists were founded, as were the communities of Owen, as indictments of the abuses of the competitive system. There was, however, no idea of eliminating profits. On the contrary the expected profits, after wages and interest upon capital had been paid, were to be entirely devoted to the "common advantage" of the working-class producers.

The burning words of "Parson Lot" in the famous tract-Cheap Clothes and Nasty-served to draw attention to the terrible conditions which prevailed in the

1 Co-operation at Home and Abroad. C. R. Fay, p. 220. 
tailoring trade, and to raise enthusiastic support for the new system of production. The first Society of Tailors was founded in I849, and was shortly followed by a Needlewomen's and two Shoemakers' associations. In I850, the Society for Promoting Working Men's Associations was founded, and opened a vigorous propagandist campaign.

As early as 1854 the Christian Socialists had to admit that their workshops had failed. The causes which led to disaster are obvious. In the first place, the men who seek employment when experiments of this nature are made are too frequently the failures of society-the men who, through lack of skill, capacity, or character, have been squeezed out of regular employment. The first essential for success-efficient labour-was therefore absent. Discipline was defective, and the men had not the necessary education to organise the work successfully, even on the small scale which was attempted.

Kingsley fully admitted the failure, though he claimed that the attempt had been made in the right direction. He owned that it would take two generations of previous training, both in morality and in drill, to make the workmen capable of association for production. ${ }^{1}$

Mr. Frederic Harrison maintained nearly fifty years ago that the necessary elements to create successful Co-operative Production were wanting, whereas in the system of Distributive Stores he saw the prospect of a real success and that it was destined to a great material and social development. ${ }^{2}$ His estimate has been proved correct in both particulars.

It is not necessary to dwell upon the failure, and the

1 Life and Letters. Vol. I, ch. xiv.

2 National and Social Problems. Frederic Harrison. p. $33^{\circ}$. 
facts are eloquent. The lesson to be learnt seems to be that the wage-earning classes had not then, and with certain exceptions have not yet, shown themselves to possess the necessary education and power of organisation to command success in any extensive forms of manufacturing enterprise. If it must be admitted that the failure of the workshops of the Christian Socialists from a material and financial point of view was absolute, yet the influence and teaching of Kingsley and his friends were not lost.

One very practical outcome of their connection with Co-operation was that the evidence which they gave before a Committee which was appointed by the House of Commons in 1850 , to inquire into the best means of improving the conditions of the working and the middle classes, led to the passing of the "Industrial and Provident Societies Act" in 1852. This Act (which was framed by J. M. Ludlow), together with that of $\mathrm{I} 862$, formed what has been named " the Magna Charta of Cooperative trade and industry." Two years later the Christian Socialists founded the Working Men's College in Great Ormond Street, where such men as Huxley, Tyndall, Ruskin, Bowen, and George Darwin freely devoted some of their time to lecturing to wage-earners. The College is at the present day still vigorously promoting educational work, in its new building in Camden Town, and has over thirteen hundred students enrolled upon its books. ${ }^{1}$

The influence of the Christian Socialists upon thought has been immeasurable. They emphasised again and again that mere external changes of condition were

1 These students, it should be noticed, include at the present time few "working men," and are drawn mainly from the ranks of shop assistants and clerks. 
powerless to accomplish much, unless accompanied by corresponding changes in life and character. They were never weary of advocating the cause of education, and of pointing out that independence and self-help would do more to change the face of society than State aid. The service which they rendered to Co-operation was no small one, and the words of Maurice, Vansittart Neale, Ludlow and Kingsley have set a high moral ideal of permanent value before the followers of the movement, which still has its influence to-day.

THE ROCHDALE PIONEERS AND THE STORE MOVEMENT

The failure of Co-operative Production diverted, for a time, the energy within the movement to furthering the more practical operations of the Distributive Stores. As Holyoake, the veteran co-operator, remarked, it seemed to many at the time " a ridiculous thing that the social regeneration of the world should consist in opening a cheese and butter shop . . . a great descent from the imperial altitude of world-building to stoop to selling long-sixteen candles and retailing treacle." 1 Retailing treacle was, however, as events proved, to have a great future.

A new impulse had been given to the Store movement three years before the Chartist agitation had been quenched in a downpour of rain. In 1844 a few Rochdale weavers had quietly, patiently, and with "the conviction of missionaries," embarked upon the formation of a society which is now renowned amongst co-operators throughout Europe and America. The beginnings of the enterprise were humble enough,

1 History of Co-operation. G. J. Holyoake. Vol. I, p. 68. 
but the aims of the Pioneers were, as befitted the disciples of Robert Owen, of great magnitude. It appears from the original rules that, in addition to resolving to establish a store for the sale of provisions and clothing, it was intended to build, purchase and erect a number of houses, and to employ the needy members in manufacture. The Pioneers were also resolved to possess themselves of land, which was to be cultivated by the unemployed or underpaid members, and to open a temperance hotel. The most ambitious of their projects was: "That as soon as practicable, this Society shall proceed to arrange the powers of production, distribution, education and government, or, in other words, to establish a self-supporting colony of united interests or assist other societies in establishing such colonies." 1 The first requisite for carrying out these extensive schemes was capital, and this was raised by weekly subscriptions of $2 \mathrm{~d}$. by the twenty-eight original members. The subscription was subsequently raised to $3 \mathrm{~d}$. and the society grew to a membership of forty! When the Pioneers found themselves in possession of $£_{2} 28$, they resolved to begin their operations. Holyoake has drawn a graphic picture of the opening of the famous store: "On one desperate evening-it was the longest evening of the year-the 2 Ist of December, 1844, the 'Equitable Pioneers' commenced business ... It had got wind among the tradesmen of the town that their competitors were in the field, and many a curious eye was that day turned up Toad Lane, looking for the appearance of the enemy ; but, like other enemies of more historic renown, they were rather shy of appearing. A few of the cooperators had clandestinely assembled to witness their

1 Co-operation at Home and Abroad. C. R. Fay. pp. 278, 279. 
own denouement, and there they stood in that dismal lower room of the warehouse, like the conspirators under Guy Fawkes in the Parliamentary cellars, debating on whom should devolve the temerity of taking down the shutters and displaying their humble preparations. One did not like to do it, and another did not like to be seen in the shop when it was done: however, having gone so far there was no choice but to go further, and at length one bold fellow, utterly reckless of consequences, rushed at the shutters, and in a few minutes Toad Lane was in a titter." So the Rochdale Stores were opened displaying, we are told, 'a scanty arrangement of butter and oatmeal,' amidst derisive cries of 'Aye, the owd weavers' shop is opened at last.' 1

The financial progress of the "owd weavers" shop was extraordinarily rapid. In 1846 the Pioneers made a profit of $f_{6} 80$ upon a business of $f_{6}, 146$. Twenty years later, though Lancashire had just passed through the throes of the cotton famine, the profit was $£ 31,936$ upon a business of well over a quarter of a million. The number of members had increased during the same period from 80 to 6,246 . In addition to the actual work thus accomplished by the original Store, a Corn Mill society had been established which did business at the rate of about $\oint_{2} 200,000$ a year. Sick, Burial, and Building Associations had also been formed as offshoots of the Rochdale Pioneers' Store. The progress during recent years has been consistently maintained, and the Pioneers now number 18,924 , with a capital of $£_{6} 384,921$.

How can we account for this remarkable success, and for the rapid growth of the numerous stores, which were subsequently founded on the Rochdale model ?

1 History of Co-operation in Rochdale. G. J. Holyoake. p. 13. 
The factors which helped to produce this achievement were first, a strong social faith, which inspired the members in those early years to undertake voluntarily an enormous amount of laborious work on behalf of their society, and secondly, the scheme was from the first placed upon both a sound and an attractive basis.

The Pioneers insisted upon cash payments, and there is no doubt that, just as Owen had discovered a new source of wealth when he substituted willing for unwilling labour, so the co-operators of Rochdale found potential wealth in this insistence upon the abolition of credit. Another secret of the success was the ingenious expedient which they adopted for disposing of their profits. The influence of Owen, who urged the elimination of "profit on price," undoubtedly reveals itself in the system of "dividend on purchase" which was adopted by the Pioneers. Finding themselves unable to eliminate profit, they decided to dispose of it in what appeared to them the most equitable manner. It was provided by the original rules that, after payments had been made to cover the expenses of management, the remaining profit was to be paid quarterly to the members, in proportion to the amount of their respective purchases. ${ }^{1}$ The stamped tin-token which has usually been given to the members of the stores of the Rochdale type, representing the buyer's claim on a share of the profits, has constituted a powerful factor in the success which such stores have reaped.

The member who found himself at the quarterly division in receipt of a few shillings or a pound, though the goods he had bought at current prices had been of the

1 The Co-operative Movement. B. Potter. p. 68. 
best quality (the temptation to adulterate had no place in the democratically managed store), naturally induced other members to join, and the fame of the Pioneers spread rapidly throughout the land. Twenty years after the shutters had been lowered with trepidation in Toad Lane the Store movement was firmly established as an important factor in British commercial life. Co-operative shops were opened in town after town throughout the Midlands, the North of England, and in many parts of Scotland, after 1844. Several corn mills and baking societies were also instituted, governed by working-men, on Co-operative principles. It is interesting to note that there is evidence that some of the old societies of the Union shop type adopted the Rochdale system of sharing the profits directly it became known.

It remains to consider what Co-operation had accomplished up to about the year I863. It certainly had not realised its highest ambitions. It had not reconstructed society, neither had it driven the competitive factory system from the field. Nevertheless, it had played a part in helping to solve some of the social problems of the day, and the value of its achievements cannot be better estimated than by the words of Mr. Frederic Harrison, written in 1865 : "The first thing that a well-managed and extensive store does in a town is to destroy a number of useless and dishonest shops all round the neighbourhood, the second is visibly to reduce destitution and the poor rates, the third is, whereit is very strong, to diminish strikes and sensibly improve wages." He further said of the store of the Rochdale Pioneers that it had affected for good the moral and intellectual tone of a large city. ${ }^{1}$

1 National and Social Problems. Frederic Harrison. p. 337. 


\section{THE CO-OPERATIVE MOVEMENT}

The direct effects of the Co-operative movement in relieving the burden of poverty, and in leavening public opinion with regard to commercial honesty, both in the buying and selling of human labour as well as treacle and long-sixteen candles, had already been considerable. 


\section{CHAPTER XI}

THE CO-OPERATIVE MOVEMENT (continued)

THE year 1863 was an important one in the annals of the history of Co-operation. It had long been realised that a wholesale source of supply, controlled by and managed in the interests of the Co-operative Societies, would greatly facilitate the work of the stores in retailing sound goods at moderate prices. After attempts had been unsuccessfully made by the Owenites, the Christian Socialists and the Pioneers of Rochdale, the North of England Cooperative Wholesale Society was founded in 1863 . Scotland followed the example of England in 1868, when the Scottish Co-operative Wholesale Society was founded, with headquarters at Glasgow.

From this time forward the Store movement has gone persistently forward, gaining in membership, and increasing both its capital and profits. It has succeeded in bringing within its area of operation not only almost every industrial district of England, the Lowlands of Scotland and Wales, but also many country districts. ${ }^{1}$

The two great wholesale federations which have

1 Co-operation at Home and Abroad. C. R. Fay. p. 280. 
contributed in a great degree to this success have proved themselves triumphs of democratic organisation, and have accomplished great things not only in distributive but in productive Co-operation. The capital which was required was supplied by the Co-operative Societies throughout the country which composed the two federations. The management of the Wholesale was entrusted to representatives elected by the societies. Purchases were made in bulk from the best foreign and English markets, and then were distributed to the societies, which retailed them to their members.

As trade and capital grew, it was decided to erect factories and manufacture some of the required articles. The English Wholesale again led the way, and founded the Crumpsall Biscuit Works in 1873 , and the Scottish Wholesale erected the Glasgow Tailoring Factory in $\mathbf{1 8 8 2 .}$ The productive departments have rapidly multiplied, and the Wholesales have gradually added boots, metal and hardware, woodworking, bookbinding and printing, corn milling, and the manufacture of textiles, including cotton, wool, silk and linen to their productive industries. ${ }^{1}$ The English Wholesale also possesses at the present time a bacon factory in Denmark and a tallow and oil factory in Australia. Most of the Scotch factories have been grouped together, and form a colony at Shieldhall, outside Glasgow, where over 5,000 men are regularly employed. The English Wholesale Factories, which employed in I9I I over $16,000 \mathrm{men}$, are situated in various parts of the country.

In addition to this extensive work of distribution and production, the English Wholesale procured a small fleet

${ }^{1} \mathrm{~A}$ considerable number of the Distributive Stores also undertake a large amount of production, notably in baking and confectionery.

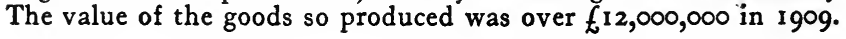


in 1876 , and undertook the work of carrying its own goods in the North Sea. The two Wholesale federations are landowners conjointly controlling Tea Estates in Ceylon. The English Wholesale also acts as banker and insurer for itself and the Stores, and has now formed an approved society for Co-operative employees under the Insurance Act. We may finally mention that it has purchasing depôts, among other places, at Liverpool, Tralee, Montreal, New York, Sydney and Copenhagen.

Shortly after the English Wholesale was founded the first of the National Co-operative Congresses was held, which led in 1873 to the formation of the Co-operative Union. The Union at the present time represents the chief propagandist association of the movement. It influences the general policy, and is responsible for the organisation of the Congress which is held yearly at some large industrial centre. The enormous growth of the Union may be shown by the fact that the membership comprised I,53 I Societies at the end of the year I9I I, with an aggregate membership of $2,760,53 \mathrm{I}$ persons. The trade of these societies, moreover, was valued at over $f_{1} 16,000,000$, and the profits realised were little short of $f_{1} 13,000,000{ }^{1}$

The connection which the Union maintains with the network of societies which exists throughout Great Britain is a close one. It acts as adviser in legal and business difficulties, it circulates literature and endeavours to stimulate educational work, with regard to Co-operative subjects. The Congress affords yearly opportunities for the discussion of vexed questions of policy and principle. Co-operators have been for many years past divided into two schools of thought. The one has

\section{Forty-fourth Annual Congress Report. p. 47.}


consisted of those who have clung with tenacity to the old aims, for which the first inspirers of the movement worked with such devotion, and the other has been composed of those who have striven to build up a huge edifice by Co-operative effort at the sacrifice of some of the principles which the idealists have regarded as sacred.

Mr. Thomas Hughes, the faithful friend of workingclass associative effort, pointed out as early as 1869 that a considerable change had by then taken place in the aims of the movement. In a speech at the Co-operative Congress he compared the work of the co-operators of I85 I with that of 1869 , and said: "In those days they recognised as their main object the making men of their members-training them to feel their relation to each other, the worth of fellowship in work, the duty of aiding and training their weaker brethren; and regarded the making of profits, the production of wealth, as a means only to this end: while, since that time, they have to a great extent given in to the prevailing heresy of our day, and have treated the making of profits and the production of wealth as the end and not the means."

The result of the cleavage in opinion which has arisen has naturally been that certain other bodies have been formed owing to what have been felt by some cooperators to be the limitations and the comparativeinelasticity of the Union methods." In I884 the "Labour Association for promoting production based on Copartnership of the workers," now known as the Labour Co-partnership Association, started on a career of vigorous endeavour. The fundamental object of this Association is to bring about an organisation of Industry based

1 Co-operative Industry. E. Aves. p. 32. 
on the principle of Labour Co-partnership ; that is to say, a system in which all those engaged shall share in the profit, capital, control and responsibility.

Closely allied to this society is the Co-operative Productive Federation, which is, as its name implies, mainly concerned with promoting the welfare of the societies of workers.

To complete the necessary outline of events we have but to add that the Women's Co-operative Guild was founded in 1883 . This " democracy of working women " has made a steady growth. It is at the present time a large federal body, consisting of several hundred branches which include some 28,000 women in their membership. Agriculture was brought within the sphere of co-operative effort in Great Britain, when the Agricultural Organisation Society of Ireland was founded in 1884 . A corresponding society was founded for Great Britain in $190 \mathbf{I}$. In 1905 the work of this society was undertaken in Scotland by a separate organisation. Finally, the Co-partnership Tenants' Housing Council, which has already done so much to provide working-class homes in Garden Cities, was founded in 1905. Such, then, in briefest survey, is the sequence of events in the history of Co-operation during the past fifty years. My task is now to attempt to give an idea of the extent and value of the achievements of some of these manifestations of the Co-operative spirit, and to state the grounds for the hopes which have been raised, that they may prove among the sure solvents of the perplexing problems of labour unrest.

\section{CO-OPERATION AND THE CONSUMERS}

The Store movement represents undoubtedly at the present time the most flourishing side of co-operative 
work. It is necessary for us to consider how far it has accomplished one of its main objects, viz., to satisfy all the requirements of the working-classes in their capacity as consumers. With regard to the size of the membership, there is still room for vast expansion. It must also be noticed that Co-operation has hitherto done but little for the lower grades of wage-earners.

It has been recently estimated that the number of members of the stores only represents about 5 per cent. of the total population of the United Kingdom. "Since, however, one member often represents a whole family, some societies even imposing this limitation in their rules, we are probably within the mark in multiplying the figure by 4 , i.e. to 20 per cent., in order to arrive at the total percentage of the population which is connected with Co-operative Stores."1 It will be seen from this estimate how far the movement still is from realising its highest ambitions.

To understand aright the benefits which the members derive, independently of the advantage of securing a supply of unadulterated goods at fair prices (which has already been emphasised), it is necessary to realise the essentially democratic organisation of the societies. Membership is open to practically all persons of either sex of over sixteen years of age. Every member who is over eighteen years of age and in possession of a one pound share is entitled to a vote. Women have been afforded practically the same opportunities of bearing a share in the management in the Co-operative movement as men. Each member carries in his knapsack, figuratively speaking, a field-marshal's bâton. "From membership to a seat on the Committee, from the

1 Co-operation At Home and Abroad. C. R. Fay. p. $28 \mathrm{r}$. 
Committee to the presidency, from the presidency to a directorship on the Board of the Wholesale Federation on the one hand, or on the Central Board of the Co-operative Union on the other, there is a graduated ladder of responsibility which the intelligent working-man may climb." 1

The esprit de corps which has been engendered by Co-operation and the training which the members have received in organisation, self-government, and the handling of difficult and elaborate financial affairs, has been, as with the Friendly Societies, of very real value to the nation at large. Individuals have learnt within the Co-operative movement to form a widened conception of the duties of citizenship, and also as members of corporate bodies to take a direct part in promoting useful legislation. It is interesting, in connection with this point, to recall the fact that the British stores were themselves the pioneers of the Bribery and Corruption Act which came into force in $1907 .{ }^{2}$

Co-operation has encouraged thrift and has offered the member of the stores opportunities for the investment of his money, which have awakened his most active interest. The benefits which he has derived from the society in which his investments have been placed have been personally felt by him in his daily home life. The most recent return of the Registrar of Friendly Societies shows that over $£ 60,000,000$ had been accumulated by Co-operative Societies, registered under the Industrial and Provident Societies Acts, at the close of the year 1910. It is hardly possible to over-estimate the improvement in health, comfort and happiness, which the

1 Co-opcration at Home and Abroad. C. R. Fay. p. 325.

2 Ibid.: p. 325. 
employment of this capital has brought to the homes of millions of wage-earners.

Another very real merit of the Store movement has been that it has familiarised a section at least of the working-classes with cash-payments. By its means members have learnt to free themselves from a load of indebtedness, and the chronic habit of subsisting with payments a few weeks in arrears. It is to be regretted that the stern insistence on cash-payments of the original Equitable Pioneers has not been maintained in all the modern stores. It is a source of great anxiety to those who remain faithful to the old Co-operative ideals to find that the majority of the stores do now give credit.

The demand which the organisation of business on so extensive a scale has made upon the intellects of those engaged in constructive Co-operative work has induced some co-operators to realise the urgent need of education. From the days when the early societies struggled to establish libraries and evening classes, or to maintain "a school for young persons at a charge of 2 d. per month," the spread of educational facilities became one of the distinct aims of the movement. The State, having accepted education as a public charge, the direction in which Co-operative energy is exhibited in the matter has naturally entirely changed since Robert Owen first started an infant school. It is now strongly felt by many of the leaders within the Co-operative movement that the obligation to instruct the members in the history, aims and technicalities of Co-operation still remains, and also that future generations will judge the work of the present time by the zeal which is shown by co-operators for the spread of education. A Committee has been appointed by the Union, which organises training courses for 
Co-operative secretaries and salesmen, and also arranges special classes for junior employees and apprentices. The report of this Committee to the Congress of 1912 shows a keen appreciation of the duty of co-operators, as employers, to train their younger workers as efficient business men and women. A large number of classes has also been formed for the members, to promote a knowledge of industrial, economic and Co-operative subjects. That these efforts are appreciated is shown by the fact that in I9I I over I8,000 students were enrolled in these classes. The Education Committee also arranges various examinations, for which 12,664 students entered in I9II. Two scholarships have been founded at Oxford in memory of Vansittart Neale and Thomas Hughes, which are open to the sons of members of Co-operative societies affiliated to the Union. ${ }^{2}$ A Fellowship has also been established within the last few years in connection with the Education Committee, which already includes 600 members and affords effective help in furthering educational work. There is much to show that the Central Board of the Union and the Committee are alive to the importance of abiding by the ancient traditions and furthering this branch of the work. Apathy has yet to be overcome amongst the rank and file of the members, and too many of the Sections are still forced to report that progress is not as great as could be wished. A great field of opportunity in educational work yet lies before the Union, and it has been strongly urged that in the matter of technical training of employees far more should be undertaken. ${ }^{3}$ The Women's Co-operative Guild has proved itself of great service in urging the claims of

1 Forty-fourtb Annual Co-operative Congress Report. pp. 60-70, 396.

2 Co-operative Industry. E. Aves. pp. 107-8.

3 Forty-fourtb Annual Co-operative Congress Report. p. 397. 
education with regard to civic, industrial and national questions. It has shown a breadth of vision and a vigorous determination, which serve to prove how well women are qualified to obtain and exercise a powerful influence in this form of working-class association. The Guild has dealt with the subject of the housing and wages of Co-operative employees, and has strenuously advocated the maintenance of the cash system. The valuable information which it has collected upon matters relating to industrial life has been placed at the disposal of Government Commissions and Committees. The Guild has also taken a keen interest in the promotion of Factory legislation, and has emphasised in many ways the duty which women owe to their country as citizens. It has also earnestly advocated the extension of the suffrage to women. Several Guild members have performed good work as Poor Law Guardians, and the close attention which the society pays to questions of public health, and the causes of poverty, are of considerable service to the community.

One further point remains to be noticed with regard to Co-operation and the consumer. How far has the movement succeeded in its aim of helping the weaker members of Society, and drawing the poorer grades of wage-earners within its net ? Here, again, as with the Friendly Societies, it must be admitted that there has hitherto been no substantial degree of success. It has failed to reach the under-world of labour. A casual mode of life, frequent change of abode, intermittent employment, all militate against the success of the efforts which are made to include the "very poor" in any form of associative effort. The Co-operative movement has almost exclusively attracted to its ranks the higher 
grades of working men and women, such as artisans and mechanics, miners, and mill-workers, and those just above or just below the classes thus roughly indicated. ${ }^{1}$ Here again, the Women's Guild has shown itself true to the best traditions of the past. It appointed a Committee, which reported in 1902, to investigate the present customs of the Co-operative movement, in their bearing on the poorer classes of society, and to show what Co-operation might do towards solving the problem of poverty in large towns. As a result of a number of practical suggestions which were made by the Committee, a branch store was opened in Coronation Street, in the most overcrowded part of Sunderland, a region which had "the highest record of death, disease and crime," and where the usual customs of pawning, drinking and fighting prevailed. ${ }^{2}$ The truly social effort which was made in connection with this experiment, and the untiring personal service which was given, were crowned with complete success, and it was effectively demonstrated: "(I) that it is possible for Co-operation to win the trade of the poorest; (2) that such trade is a financial gain to the whole Society; (3) that the Store is a sure means for gaining the confidence and friendship of the people, establishing a relationship built on self-help and unspoilt by the demoralising effects of charity; and (4) that the Store might become a foundation and centre for constructive social work in parts where it is most needed." 3

Obviously co-operators possess in the Store a weapon of great potential value for combating distress in the poorest quarters of our towns. It is a matter of such profound importance that co-operators of all shades of

1 Co-operative Industry. E. Aves. p. 112.

2 Women's Co-operative Guild. M. Ll. Davies. pp. 83, 9o.

3 Ibid., p. 92. 
thought should, imbued by the highest aims of the Spirit of Association, awaken to their responsibilities in this matter, that we quote at some length Mr. Aves's words urging the importance of following the Sunderland example, and including the lower-grades of the workingclasses in the Co-operative movement: "The spread of the 'poor store' is not, however, likely to be rapid, unless the flame of a new enthusiasm and of a new determination to realise old hopes burn into the hearts of large numbers of those who guide the movement both at headquarters and in the societies. The line of least resistance is not only giving them so much to do, as often to absorb most of their time and energy, but it leads them on, and for some time it will probably be pioneers alone who will tread, not where success is most assured, but where needs are greatest. The importance of the new departure is thus not to be measured by its achievements, considerable though they have been, but by the hopes and by the determination to which it may still give rise." 1

\section{CO-OPERATIVE STORES AND THEIR EMPLOYEES}

We have already stated that there has been no small difference of opinion as to questions of policy within the Co-operative movement. This has been especially the case with regard to the practice and principle of profitsharing with employees. Since the year 1861, when the Rochdale cotton mill, after a severe struggle, surrendered the practice of giving the operatives a share in the profits, the question has constantly afforded a bone of contention to British co-operators. For some inexplicable reason a different standard has at times

${ }^{1}$ Co-operative Industry. E. Aves. p. 150. 
been manifested within the movement, with respect to the treatment of the employees engaged in the manufacture of goods, and those employed in the work of distribution. The "Co-operative conscience" has acquiesced more readily in the exclusion from profitsharing of the salaried officials and weekly wage-earners in the shops, than in the case of those who were actually engaged in manufacture. It need hardly be said that, whatever view may be taken of the moral obligation to share profits with workers, the tendency to regard the rights of various classes of labour from different standpoints is entirely inconsistent.

The majority of the retail stores, as represented by the English Wholesale Society, have practically abandoned profit-sharing with their employees. The advocates of the " dividend-on-purchase" have carried the day.

Though the system of profit-sharing in the distributive side of the Co-operative movement is only attempted by a small number of the Stores in Great Britain, the practice prevails to a somewhat larger extent in Scotland. It has already been shown that extensive manufacture has been undertaken by the great Wholesale departments of the two countries, and it is here that the divergence of practice between the Scotch and English methods reveals itself most strongly. Whereas the English Wholesale gives no share at all of its profits to its employees, the Scottish Wholesale, with a trade of over three and a half millions, and productions of over two millions, enables the workers to "reap a good harvest as their share of the profits."1

In order to appreciate the point of view of the large

1 Trenty-sixtb Annual Report Labour Co-partnersbip Association. p. 9 . 
majority of co-operators, who advocate that fixed rates of wages should be awarded to employees, it must be clearly understood that the Co-operative Store movement has been developed mainly in the interests of the consumers. Distribution through the machinery of the stores led to production for distribution. The articles which are manufactured by the Wholesales are produced solely to supply the known or anticipated wants of the members. The productive work of the Co-operative Store movement must therefore be regarded as distinct from that of the "workers' societies," which are to some extent controlled and organised by workmen themselves, and which enter into competition with ordinary industrial enterprise in the open market. These societies will receive further attention in Chapter XIII.

Profit may be distributed in three ways: to the capitalist, to the consumer, or to the workers, which includes all brain and manual workers-the manager, the skilled artisan, and the shop-boy. The consumers in the Co-operative movement are composed entirely of those who contribute their services towards the production and distribution of the required goods-the capitalists and the workers in both workshops and stores. Each consumer benefits in proportion to the amount of goods which he consumes, and the margin of so-called profit is disposed of in the Co-operative movement, in the main, in this way. The employees are encouraged to become members, and thus are entitled to a share of the profits as consumers.

The essence of the movement is democratic control by all the members, but in this respect we find that the employees submit to certain disqualifications. As a rule they possess no vote, and they are not permitted to serve 
in official positions. It has been considered inexpedient that these powers should rest with the section of members whose personal interests must frequently be at stake, and might conflict with those of the main body of consumers.

The Stores may therefore be said to have very generally adopted the usual existing type of relationship between employers and employed, and it remains to compare the condition of their employees with those engaged in similar industries outside the Co-operative movement.

Co-operation represented in its first inception a protest against the injustice which it was felt prevailed under the competitive system. This underlying motive has not been without its influence in the treatment which has been accorded to labour in Co-operative factories, mills, and stores. In the evidence which was given before the Labour Commission in 1892, it was maintained that the Co-operative system of production for an organised market conduced to continuity in employment, and tended also to check fluctuations in wages. In the seasonal trades, for instance, it was maintained that every effort was made to ensure continued employment by anticipating the demand and working for stock.

It is sometimes asserted that in the past the English Stores underpaid their managers and shop-hands. At the present time, however, co-operators may be said, generally speaking, to be good employers, paying at least Trade Union rates of wages, and making reasonable arrangements with regard to hours of work and conditions of employment. In connection with this point it is interesting to recall the fact that co-operators were the first to institute the weekly half-holiday, which has recently been enforced by law. It is, indeed, claimed, and 
probably with justice, that Co-operative hours and general conditions compare favourably with those of the outside world. It is, however, a significant fact that the employees have formed a strong Trade Union to protect their interests, and the vigorous campaign which has been carried to a successful issue by the Women's Guild to secure a minimum wage, is indicative that there has been a good deal of dissatisfaction in that branch of the movement with regard to the payment of employees. 


\section{CHAPTER XII}

\section{CO-OPERATION AND AGRICULTURE}

\section{AGRICULTURAL CO-OPERATION IN IRELAND}

There has always been a great difficulty in promoting associative effort amongst farmers and agricultural labourers. A life lived in the open fields, and often in enforced isolation, does not conduce to width of outlook in business or educational matters, or to the desire for social intercourse, which impels men to combine. The movement towards Co-operation in Great Britain and Ireland for agricultural purposes, has, therefore, not been primarily a spontaneous or a democratic one. Whereas the Friendly Societies, the Rochdale Pioneers, and the Trade Unions owed their first inception to the efforts of wage-earners, the introduction of Agricultural Co-operation has been due to the enthusiasm of educated men, who, realising how much it had accomplished for small farmers on the Continent, have given time, energy and devoted service to induce agriculturists in the United Kingdom to co-operate. These efforts have been made with a dual object. The aim has been not only to increase the economic stability of the 
workers upon the land, but also to place within their reach new possibilities of building up a social and at the same time a self-reliant life.

It is well known that with Ireland rests the honour of having led the way in organising Agricultural Co-operation in the United Kingdom. In the year 1889 Sir Horace Plunkett, with the help of Mr. J. C. Gray, started the first Co-operative Dairy or " Creamery." The general organisation of the Co-operative movement in Ireland, which from that date has made continuous progress, was largely based on Danish methods. When Denmark, a purely agricultural country, was faced with ruin after the disastrous war with Prussia in 1865 , a national scheme of Co-operation amongst agriculturists was devised, which enabled the country to recover from financial depression, and to build up a prosperous dairy trade. Agricultural Co-operative Societies were formed ; purchases for the farmers were made in bulk, at wholesale prices; Co-operative factories for the manufacture of butter and cheese and the curing of bacon were erected. These factories were supplied with up-to-date machinery, and presided over by expert managers. ${ }^{1}$ Irish cooperators, in addition to developing a scheme such as this, for dealing with their dairy produce, have founded Agricultural Banks and Credit Societies based on the German Raffeisen model.

Ireland is a country where the need for associative effort, whereby to improve the prospects of the small farmer, is particularly great. Both the soil and climate are eminently suitable for cattle raising, and dairy farming. The large majority of the population is engaged in the agricultural industry. The rural problem is in fact

1 Co-operation. July-August, I9I2. 
the heart of the Irish question. As the home demand for farm produce is quite insufficient to absorb the supply, the farmer is forced to look further afield for his markets. $\mathrm{He}$, therefore, requires facilities for obtaining information respecting suitable foreign and English markets, and adequate machinery to aid him in distributing his butter, eggs, milk and bacon. These advantages can only be secured to him by association. By means of Co-operation the farmer can also buy machinery, seeds, and artificial manure at wholesale prices. $\mathrm{He}$ is enabled to hire expensive machinery, and secures the command of valuable stock for breeding purposes.

The leaders of the movement, who undertook the task of attempting to create a "Co-operative character" in Irishmen, met with considerable opposition, and had special difficulties to contend with which have been well described: "The Irishman, like his Anglo-Saxon brother, began by suspecting that the pioneers were trying to make something out of him; when convinced of their sincerity, he became sentimentally enthusiastic, and his sentiment had to be hardened into a business-like stability. Above all, it was necessary to fight against his fatalism, that feeling of despair, the heritage of an unhappy past, which makes Irishmen as inefficient in the "ould counthry" as they are efficient abroad, that belief in a luck which, if one credits the Irishman, has always been uniformly perverse and unfriendly." 1

The ground, however, once ploughed, and the seed once sown, the work of Agricultural Co-operation in Ireland has been rewarded with remarkable results. It has already been the means of transforming the condition of a large part of the island from dire poverty to com-

1 Co-operation at Home and Abroad. C. R. Fay. pp. 102, 103. 


\section{CO-OPERATION AND AGRICULTURE}

parative prosperity. 1 It is claimed that within six years of the initiation of Co-operation, the idea of self-help had taken a firm hold of the imagination of the people.

The direction of the movement passed in the year 1894 into the hands of the Irish Agricultural Organisation Society, which has its headquarters in Dublin. By means of maintaining a strict neutrality with regard to political and religious questions, it has obtained the support of persons belonging to widely different schools of thought. The Society is now able to report that the growth of the movement is steadily and satisfactorily maintained. Some 880 societies were in existence in 1910. In addition to a very large number of "creameries," and agricultural and credit societies, associations have been formed to promote home-industries, bee-keeping, and the growing of flax. ${ }^{2}$

There is every reason to believe that Co-operation, which is thus firmly established in Ireland, and has already proved itself of such value, when regarded from a purely economic standpoint, is destined to a great future in helping to secure a stronger financial position for the Irish nation. In addition, however, to the hope of rendering this service, the movement places before itself a far higher ideal than that of merely ensuring commercial success, and aims at performing its share in the great work of character-building, and in promoting a moral and intellectual advance. It is claimed for the Agricul-

1 A.O.S. Leaflet. No. 42.

2 The Development Commissioners recommended the I.A.O.S. for a grant of $£ 2,000$ in respect of the period ending June 30 th, 1912, and a further grant to be calculated at $f_{1}$ for each $f_{1}$ subscribed to the funds of the Society from other sources. The Government have after prolonged delay endorsed the recommendation; and it may be hoped that, if the conditions which are imposed can be accepted by the Society, the work of agricultural organisation in Ireland will be greatly facilitated and stimulated by the financial support from the Treasury. 
tural Banks that they exercise a great educational influence. They insist upon their members being of good character, upon punctuality in payments, upon proper investments being made, and they also tend to teach the true value of money. "In these societies, more than in any others based on Co-operation, is it made evident to all the members-by the fact of their common liabilitythat in brotherly feeling among them lies their greatest hope of success." 1

Raffeisen held the opinion that in the poorest communities there is a perfectly safe basis of security in the honesty and industry of the members of these banks, who pledge their joint credit for the money deposited in them. The experience of Ireland has fully confirmed the view that social influences are quite sufficient to command obedience to the laws of these associations. ${ }^{2}$

The Dairies are adding work of a social and educational character to their purely economic functions. The farmers' societies have their libraries and reading rooms, while: "Social gatherings of every kind, dances, lectures, concerts and such like entertainments, which have the twofold effect of brightening rural life and increasing the attachment of the members to their society, are becoming a common feature in the movement, and this more human aspect has attracted to it the attention of many who do not understand its economic side." ${ }_{3}$

CO-OPERATIVE AGRICULTURE IN GREAT BRITAIN

British Agricultural Co-operation prior to the dawn of the twentieth century has been caustically described as a "mere blank, darkened by a few failures." Since the

1 Co-operative Credit. I.A.O.S. Leaflet, No. 4, p. 4.

2 Ireland in the New Century. Rt. Hon. Sir H. Plunkett. p. 196.

3 Ibid., p. 259. 


\section{CO-OPERATION AND AGRICULTURE}

foundation of the Agricultural Organisation Society in 190I, there has been steady progress in this form of combination, which has not been surpassed during the same period of time by any country in Europe. The objects of the Society which has accomplished this work, are : "To secure the co-operation of all connected with land, whether as owners, occupiers or labourers, and to promote the formation of Agricultural Co-operative Societies for the purchase of requisites, for the sale of produce, for agricultural credit, banking and insurance, and for all other forms of Co-operation for the benefit of agriculture."

There has been no little difficulty in breaking down the sturdy British farmer's prejudice against combining with his neighbours, though it appears to have been less considerable than in the case of his Irish brother. The agriculturist is proverbially suspicious of change and loath to act on faith, demanding the testimony of visible results. He also has a marked preference for making his own bargains, which is in part founded on his aversion to his neighbour knowing the amount of his takings, and in part on his liking for the relaxation of "market-day." The result of this preference for "splendid isolation" in business matters was amusingly illustrated by the evidence given before the Departmental Committee of the Board of Agriculture on Small Holdings, when it was stated that the result of this characteristic of the Lincolnshire small holder was, that the Spalding duckling passed through the hands of four middle-men before it reached the consumer. Agricultural distributive organisation is the only remedy for such utter waste of human effort, and also for the loss of the farmer's share in the profits. 
Since the year I90I, when the efforts of the Society were first directed to organising Agricultural Co-operation, the number of associations which have been formed and affiliated to the Society has risen, year by year, until, at the close of I9II, some 463 societies were in existence. A brief account of some of the objects which they have included within the scope of their operations will afford the best illustration of the practical nature of the work.

Some of these societies purchase, for their members, manures, seeds, machinery, etc., at wholesale prices, and they further take every precaution to insure the purity of the goods, and frequently submit samples to analysis, thereby protecting the members from imposition. Other societies endeavour to secure the best market for the sale of produce, by organising the milk supply on a Co-operative basis, by establishing Cooperative butter and cheese factories, and egg and poultry depôts for sorting, grading and packing. They also grade and pack fruit. They serve to reduce the cost of transport by bulking the consignments of the members, by arranging terms with the railway companies and carriers, and in some instances by opening up remote districts by motor traction. They give financial help to the farmer by arranging for all kinds of agricultural insurance, and by establishing Agricultural Credit Societies, by means of which the smaller agriculturists may secure small loans on easy terms.

Finally, some societies acquire land and sublet it to their members in small holdings or allotments. ${ }^{1}$ The Small Holdings and Allotments Act of 1908 empowered the local authorities to let land to Co-operative Societies.

1 See Annual Report of the Agricultural Organisation Society Ltd. for 1910, pp. 9, 10. 


\section{CO-OPERATION AND AGRICULTURE}

If the County Council proves unwilling to acquire small holdings, the Board of Agriculture has power to act, and if landlords refuse to offer suitable land it may be purchased under compulsion. That this Act met a felt want is shown by the fact that no fewer than 194 small holdings and allotment societies are already affiliated to the Agricultural Organisation Society.

The movement which has gone forward on these lines is still in its infancy, though progress has already been strikingly rapid. We have now to consider what grounds there are for anticipating that the introduction and wide extension of methods, such as I have indicated, may bring a new prosperity to British agriculture. How far may it be hoped that Co-operation, even if it does not induce men to return to the land, will at least persuade those who are there to remain on it, and enable them to succeed where their living has hitherto been precarious, and will also help to introduce the social element and interest into life, in search of which so many countrymen have hitherto poured into the towns?

$\mathrm{Mr}, \mathrm{Fay}$, in his account of Co-operation at Home and Abroad, published in 1908, has analysed the effect of the introduction of scientific methods of farming and Cooperation upon one another in several European countries. He marks as the result of his study of the condition of agriculture in Germany, Denmark, Switzerland, France, Belgium and the United Kingdom, that : "Cooperation is no occasional phenomenon, but one aspect of a movement affecting profoundly the agriculture of Europe." 1 It is impossible for us, in the present volume, to attempt to recount the history of the march of the "Agricultural Revolution" which he has so admirably

1 Co-operation at Home and Abroad. C. R. Fay. pp. 191, 192. 
described. The reader who is interested in agricultural subjects is referred to the book itself. It suffices to say that he points out that scientific changes in the processes of agriculture, such as the introduction of chemical manures, the invention of the electric and steam plough, binding and mowing machines, and the economic changes which have caused the farmer to produce primarily for the open market, instead of merely for his own consumption, as in more primitive days, have left two parties in power. The one is the large farmer, the other the small farmer co-operatively organised. The opportunity which Co-operation affords to the small farmer to buy seeds and implements cheaply, coupled with the effective organisation of distribution, whereby reasonable rates may be secured for even small quantities of produce, serves to put him in a position in which he can hold his own with those who are engaged in farming on a larger scale. In country after country the need of the individually weak to gain strength by collective action has been manifested in Agricultural Co-operative associations.

Great Britain only recently entered the field, but she has hitherto been the country of large farms. When, during the first half of the nineteenth century, the cultivation of cereals was the most profitable form of farming for Western Europe, large-scale farming was, perhaps, the most suitable method of agriculture. A new cycle of events has altered the situation. The great grain-growing areas of the world have been opened up in America, Canada, Argentina, and Siberia; the cost of carriage from foreign lands has been reduced; and it has become increasingly hard for the British farmer to com-

1 Co-operation at Home and Abroad. C. R. Fay. p. 208. 


\section{CO-OPERATION AND AGRICULTURE}

pete in growing cereals. The consequence is that the tendency to revert to small farms is showing itself in Great Britain. The more intensive forms of agriculture, such as market-gardening in fruits, vegetables and flowers, are assuming an increased importance. Dairyfarming and the raising of poultry and pigs have received a like impulse. It is obvious, therefore, that by the very trend of economic forces, the lines upon which agriculture is developing are of the nature to require the help of the Spirit of Association as an essential element by which to secure success. The small farmer standing alone has a diminishing chance of successfully entering the field against large farmers and the members of Co-operative societies. Neither can his produce secure an adequate return in a market in which it has to compete with foreign goods, which have had the effective support of societies for Co-operative supply and distribution.

The signs of the times certainly appear to indicate that Agricultural Organisation, already so successfully inaugurated, is likely to make continuous headway in Great Britain. The future is big with possibilities. There is a growing recognition on the part of the Government that a town-bred, town-reared race loses in physical stamina. The Agricultural Organisation Societies of both England and Scotland now receive grants from the Development Fund towards helping them to spread the principles of Co-operation. This encouragement and recognition will give, it may be hoped, a new impulse to the whole movement.

Those, however, who have the fullest knowledge of country conditions will be the first to realise that the future of English agriculture is bound up not only 
in the growth of Co-operative effort, but in a wise solution being found to the problems of rural housing and land tenure, which cannot be considered here.

The degree of permanent success which Agricultural Co-operation may achieve will also largely depend upon the enthusiasm for education which the members exhibit. An admirable suggestion has been made by the North Eastern Counties Sectional Committee, that Institutes should be established, which would act as centres of information and where lending libraries and reading rooms could be placed at the service of the farmers, their wives and children, and where lectures could be delivered on market days. ${ }^{1}$ It is to be hoped that by means of efforts such as these, the aims will be realised of those who are convinced that the spread of knowledge affords the sure road to success. The present education authorities have also a part to play in the work of renewing our country life. It is strongly urged that, at the present time, the education afforded in our rural schools is often more suited to train young clerks than young agriculturists. How far this is really the case should be made a matter for searching inquiry. A duty of demanding suitable educational advantages for the children in our villages and country sides certainly rests with organised agricultural cooperators.

1 See Annual Report of the Agricultural Organisation Society for 1910, p. 26. 


\section{CHAPTER XIII}

\section{CO-PARTNERSHIP AND INDUSTRIAL UNREST}

The symptoms of industrial unrest which have been exhibited during the last two or three years are too well marked, and have received too much description and analysis, to require emphasis here. The broad facts are fully recognised that we now see the forces of organised labour and of employers marshalled in opposition to one another, and that their supposed conflict of interests leads to frequent outbreaks of hostility. In the keen desire of each side to obtain the mastery, industry has suffered, and the nation has, during the railway, coal, and transport strikes, passed through periods of profound anxiety. Though the wealthy and the middle-classes have felt but small inconvenience, a vast number of wage-earners have been reduced to a condition of poverty from which recovery, even should the industrial machinery run smoothly for the next few years, will inevitably be slow.

The whole experience has induced the community to take an infinitely greater and more sympathetic interest in labour questions. There has been an extensive stocktaking of the conditions of work and pay 
of the wage-earners in several of our largest industries, and there is much to show that it has resulted in a quickened sense of justice, an increased knowledge of and respect for the man who labours in factory, workshop, mill or mine, a stronger desire that work should receive its fair reward, and that "sweating" in every form should be banished from the face of the earth. The inquiries which have been made into industrial conditions have served to let in air and light-the finest of antiseptics for the wounds of society.

If the whole experience has, as I believe, stirred the heart of the public, naturally enough men of all shades of opinion-students of economic science, capitalists, employers, and working-men-are severally inquiring what are the causes which have produced this recent cycle of labour troubles, which has in certain respects differed materially from any other through which the nation has hitherto passed. Amongst a host of reasons which have been suggested as offering the true explanation of the unstable condition of thought and action in the labour world, we have been informed that the workingman now reads Ruskin and Carlyle, and that such reading breeds a "divine discontent," that our public schools give a training in caste which accentuates the division of class from class. We are told that the working-man sees the motor whirling by, and a section of society apparently wholly engaged in the mere pursuit of pleasure, and that he revolts from the comparative monotony of his own life. It is maintained that improved education has opened up a new world of aspiration which has unfitted him for a life of manual labour: that booklearning does not equip him to lead the life of a hewer of wood and a drawer of water in a spirit of contentment. 
These factors one and all may be said to have contributed in greater or less degree to the dissatisfaction which has been growing amongst the workers. The causes are, I believe, as Mr. John Burns shrewdly observed of the problems relating to the Poor Law, "multiform," whilst the remedies are "multiplex."

Three facts, however, seem to stand out as having contributed more powerfully than any others to bring the unrest to a head. First, the cost of living has increased. Secondly, trade has been in an extraordinarily prosperous condition for some years past; nevertheless, the workingman finds himself in the same, or even in a lower position financially, than was the case some fourteen years ago. This circumstance has convinced him that in the present industrial system he is the victim of injustice. Thirdly, the wage-earner seems to have lost hope that collective bargaining, through the normal methods of Trade Unionism, will ever succeed in securing for him his due share in this world's goods. He is also somewhat impatient with what appears to him the slow progress of the Parliamentary Labour Party. Disillusioned, he looks, perhaps not unnaturally, to drastic measures to improve his lot.

Statistics prepared by the Board of Trade have shown that during the last few years the cost of living has risen considerably. Professor Ashley, who has investigated the subject, has arrived at the conclusion that it is a fairly safe conjecture that a working-class family would have required between $23 \mathrm{~s}$. and $24 \mathrm{~s}$. in 1910 to provide themselves with all that they might have obtained for a sovereign in 1896 . Though wages have risen simultaneously in the skilled trades, and also, though to a lesser extent, in the unskilled trades, the Board of Trade 
evidence shows that they have not risen sufficiently to meet the increased cost of living. Professor Bowley, who has also investigated the question of the rise of prices, has arrived at a somewhat different conclusion to the Board of Trade, and marks a smaller rise in prices. Even if, however, the more optimistic estimate be accepted, there is still no means of proving that during a time of marked prosperity there has been any increase at all in the real wages of the working-man. ${ }^{1}$ Though social legislation and notably Old Age Pensions has lightened his burden to some extent, he clearly feels that he has been excluded from his share in the increased profits which have been made during those years of plenty. The speech of the President at the Trades Union Congress in September, 19I2, voiced the deep and justifiable discontent which these facts have aroused.

Our third point, that the working-classes have to some extent lost faith in the normal methods of collective bargainirg, will be more fully dealt with in connection with the recent phases of Trade Unionism. The signs that this is the case are obvious enough. The leaders during the recent disputes were shown, in some instances, to have lost control of their men, and the less scrupulous of them, having aroused a ferment of discontent, were unable to quell it, or to hold the men to their agreements. And also such acceptance as the anarchic doctrines, taught by some Syndicalists, has received has been a sure sign that the men are disheartened at the small amount of progress which has been made in their material condition during recent years. They have to some extent lost hope of gaining further ground through the normal methods of Trade Unionism. We must also

1 Wbat the Worker Wants. Daily Mail Inquiry Article, by Professor W. J. Ashley. pp. $47,4^{8}$. 
notice the fact, pregnant with meaning, that the conflict has not been most acute where the grievances have been greatest, which tends to show that the wage-earning system, on its present basis, fails to satisfy the increased social, intellectual, and material demands of the higher grades of workers; that they feel the instinctive desire to continue to climb the mountain of progress by the path marked out by Mazzini : "From slave to serf, from serf to wage-servant, from wage-servant to partner."

If we admit that the present condition of industry is such as to call for remedial measures (and it is impossible to deny that discontent is rife); that a not inconsiderable number of manual workers still fail to obtain a living wage; that families are to be found throughout the length and breadth of the land, whose earnings are too small to secure them a healthful subsistence; it remains for us to consider what the Spirit of Association may yet accomplish in giving the worker a larger share in the great wealth of the country, and in substituting peace for hostility.

Heroic remedies, such as the State ownership of all the means of production and distribution, are being widely advocated, but even were such a re-modelling of society practicable it is hard to conceive any system of industrial life under which discontent would be greater than under the régime dear to the heart of the Socialist. A great danger which lies in the teachings of the Socialists consists in the fact that the exponents of Socialism alone claim to be able to render all things new, whereas, those of us who can see no connection between the vision which beckons the Socialist and the laws which govern human nature and make for progress are forced frankly to admit that we can advocate no one specific as a panacea for 
social distress. There is, I believe, a growing conviction amongst thoughtful men and women that nothing but a national turning to righteousness, bringing a higher conception of justice and a fuller obedience to the claims of duty, will finally allay the trouble, and that all the moral, educational, and religious forces which tend in that direction serve to help travel-stained humanity to make its halting way along the road of progress.

To wander into the bye-paths of this discussion would take me beyond my immediate province, which is to consider what aid the Spirit of Association, as revealed in Co-partnership, may give in helping to find an answer to the Sphinx-like riddle of industrial unrest. The crucible in which I would test it is its power to raise the moral tone of the industrial world. I firmly believe that forces are at work, within the Co-partnership movement, which contain in their very essence the germ of much that will bear fruit in coming years in removing some at least of the causes of industrial unrest.

Before actually considering what Co-partnership and profit-sharing have achieved, or may yet accomplish, the question in studying the Co-operative movement, and remembering the traditions of Owen and Kingsley, naturally forces itself to the front: Is there any immediate prospect of workshops, organised and controlled by working-men, and competing in the open market, serving to any great extent to modify and improve industrial conditions? Though such industries have certainly made some advance since the days of the first Christian Socialists, I can find no grounds for supposing that there is any probability that the number of workers' societies will increase in the near future. The Report of the Labour Co-partnership Association for the year IgII 
shows that there has been no great progress in this phase of the Association's work: "The increase of societies, so marked some years ago, does not continue. Perhaps one reason for this is that industry has become more and more specialised; and the introduction of machinery into most trades makes it more difficult for workingmen to raise the amount of capital needed for the starting of a modern factory. The tendency of the age is for large concerns to be started with enormous capital behind them. Whatever the reasons, the fact is clear that fewer attempts are made nowadays than in the past by working-men themselves to join together for manufacturing purposes." 1 It must, moreover, be noticed that these "workers' societies" tend to lose the characteristic features of the completely "self-governing workshop," as that expression was used by the Christian Socialists. A committee is usually elected consisting partly of member-workers and partly of outside shareholders. This committee appoints a manager who holds the same position that he would in any other business. The control which the workers possess is exercised solely in their capacity as shareholders, and through their - representatives on the committee. Each worker receives a share in the profits, and thus becomes a holder of capital. There is a growing tendency for some of the Productive Societies to become close corporations and to employ workers who are not members.

It is evident then that there is no hope that the general condition of labour will be improved, or industrial discontent allayed in the immediate future, by means of self-governing workers' societies. It is a significant fact that the number of workmen's Co-operative Societies has

1 Twenty-sixth Report; p. 6. 
dropped from 125 in 1903 to 111 in 1910 . It is satisfactory to know that the societies which remain are on the whole doing well, and are securing an increasing volume of trade. All honour is due to the men who have founded them and conducted them successfully. It is no small triumph, for instance, that it is reported of the Kettering Clothing Society that: "While paying better wages and working shorter hours than many firms in the same industry, it has made profits of a very satisfactory character." 1 If the workers' societies are unlikely to show any considerable expansion in the near future, we believe, on the other hand, that the efforts which are being made to carry the principles of Co-partnership into the wider world of industry are destined to be crowned with increasing success. There is every reason to hope that the number of private firms which will adopt schemes of profit-sharing, and the representation of the workers on boards of management, will make a steady if slow growth.

One important attribute of Co-partnership schemes is that they are capable of infinite variety and modification, and this elasticity gives boundless room for experiment, whereby to discover the exact system most applicable to each individual industry. Mr. Schloss in his Report to the Board of Trade on profit-sharing in 1894 drew attention to the fact that in hardly any two cases was the system adopted identical in all particulars.

Three chief characteristics, however, generally mark the complete Co-partnership scheme :-

I. The worker receives a share in the profits.

2. A part of the profits are returned to him in the form of a share in the capital of the business. The worker by

${ }^{1}$ The Labour Co-partnersbip Association. Twenty-sixth Report. p. 7 . 
this means secures a direct interest and ownership in the concern. He stands to gain in the years of plenty, and if a loss occurs in lean years he suffers in common with other shareholders.

3. Representatives of the employees are given a voice in the management of the business. Where this is possible it is found to possess great advantages. The men learn thereby to understand the difficulties, responsibilities, and arduous nature of the work of the employers, whilst the employers gain a sympathy with, and insight into, the needs of their men, through direct personal intercourse. The classic example of Co-partnership in England is the scheme which was introduced by Sir George Livesey in connection with the South Metropoli$\tan$ Gas Company in 1889. It is unnecessary for me to examine it in detail ; it suffices to say that it constitutes a " complete co-partnership," in which "capital, custom, and labour are all united by a common bond of interest." The Company is able to report that the scheme which was introduced as the sequel to a labour dispute has been rewarded by continuous success, and at the present time some 5,400 employees share about $£ 43,000$, which represents $8 \frac{1}{4}$ per cent. on the year's wages.

The example of the Metropolitan Gas Company has been widely imitated, and at the present time the principle has been applied to Gas Companies employing nearly $50 \frac{1}{2}$ millions of capital, or over half of the entire capital devoted to the gas industry in the country. There are indications that some of the English electric lighting companies are considering the introduction of profitsharing on somewhat similar lines. ${ }^{1}$ There is every reason

1 The Labour Co-partnership Association. Twenty-sixth Report, p. 10 . 
to hope that the system which has proved so beneficial to the one industry may be introduced with like success in the other. There are also signs that profit-sharing may gradually make headway in municipal undertakings. Profit-sharing has been in action for some years past in the Stafford Municipal Gas Department, and has recently been adopted by the Municipality of Belfast in the Tramways Department. ${ }^{1}$

In addition to the adoption of Co-partnership by a large number of Gas Companies, other important and well-known firms have devised schemes of profit-sharing or Co-partnership and have introduced them into their businesses. $^{2}$

Advance in this respect has not hitherto been rapid, and there is no denying that numerous obstacles lie across the path of progress. Employers have shown reluctance to take the trouble which so radical a change in the system of conducting business involves. "The first and chief difficulty," wrote Sir George Livesey, "is that employers generally do not see its importance, and are not therefore disposed to take it up, and give the necessary time and attention to secure success; for it certainly will not work itself. It must be worked as earnestly and intelligently as any other branch of their business." 3 All industries do not lend themselves equally to fully developed Co-partnership, or even to the simpler expedient of profit-sharing. Where success hinges on the prompt decisions of a master-mind, and where secrecy

1 The Labour Co-partnersbip Association. Twenty-sixth Report. p. I 2 .

2 I may mention for example Messrs. Lever (Sunlight); William Thomson and Sons Ltd.; Messrs. Plaistowe and Co. (jam manufacturers); Messrs. Hazell, Watson and Viney; and J. T. and J. Taylor, of Batley.

3 Metbods of Social Advance (ed. by C. S. Loch). 
with regard to methods of production, or as to contracts, is desirable, there are difficulties in creating boards of management. The objections to giving the working-man a share in the general run of businesses are, however, rapidly disappearing. Education, both in the schools and in his own democratic organisations of the Stores, the Trade Unions and Friendly Societies, all serve to fit him for posts of responsibility, involving a knowledge of financial affairs.

In businesses in which the margin of profits is small, and the conditions of trade are precarious, or subject to violent fluctuations, the difficulty of planning and carrying to a successful issue a scheme of profit-sharing is great. But even where these last conditions are present, it is well to remember that the bringing into play of the reconstructive forces of energy, loyalty and good-will, which the personal stake in the welfare of a business involves, may prove of no small assistance in improving the financial condition of the industry concerned.

A certain amount of distrust of Co-partnership schemes has been evinced in the past by Trade Unions. But if the number of schemes increases and the agreements are seen to be justly carried out, and to be inspired by a genuine desire to improve the terms of employment, any suspicion which remains will, it is to be hoped, shortly vanish. The principal objections which have been offered by Trade Unionists in the past are : That the existence of the profit-sharing scheme has of itself a tendency to keep the wages of the employees below a proper level; that it leads to an undue amount of overtime being worked, and to work being done at unduly high pressure and with too small a staff. It is also urged that it induces the workmen to connive at the breach of 
Trade Union rules, and so tends to undermine the power of Trade Union combination and to remove the scope and field of operation of Trade Unions. ${ }^{1}$

With regard to the first objection, it vanishes completely when it is clearly understood that in the case of all the schemes which are linked with the Labour Copartnership Association it is required that the workers shall receive a share in the profits only after a Trade Union standard rate of wages has been paid.

The contention which has been made in relation to the workers' societies that: "What the worker gains in profit he loses in wages," has been shown to be capable so far as statistics exist of direct disproof. "Investigation made in 1900 with regard to twenty-four workers' societies gave the following results: (I) that where there was an effective Trade Union in the district, the Co-partnership workers were nearly always members; (2) that the wages paid by Co-partnership societies were higher on the whole by 9 per cent. than the Trade Union rates in the district, while the average number of hours worked per week was $5 \mathrm{I}$ as against 53 in outside workshops. These figures are incomplete, but they sufficiently rebut the suggestion that workers' societies habitually derive their profits from the reduction of wages." 2 With regard to the second objection, in so far as it is based on the very right feeling that the men should be protected from undue strain and over-exertion, there is not the smallest doubt that it can be easily met by adopting proper safeguards. That unwholesome speeding-up has no place in

1 Report on Profit-sharing prepared by Mr. Schloss for the Board of Trade.

2 Extract in résumé in Co-operation at Home and Abroad (C. R. Fay. p. 232); from a paper read by Mr. Robert Halstead, before the economic section of the British Association on September Ioth, I 900. 
well-managed Co-partnership may be illustrated by a description of Mr. Thompson's woollen mills: "In the Thompson Huddersfield mills, there is no piecework, no overtime, only the weekly wage; no driving is allowed. The hours of labour are limited to forty-eight per week. The workers are given a whole week's holiday in August, and in addition they enjoy the benefits of a non-contributory sick and accident fund, and of a $24 \mathrm{~s}$. per week pension fund . . . The surplus profits, after the fixed reward of capital-viz., interest at the rate of 5 per cent. per annum - has been paid, are divided between labour and custom; and here again the capital sunk in the mills has been written down from $£_{6} 8,655$ to $f_{0}, 680$. Unprofitable machinery is scrap-heaped. The mill has only the best, most up-to-date machinery, and all connected with the works, shareholders and workers, live together like a happy family." 1

In so far as the second objection is based on the fallacious assumption that the larger the number of men employed and the smaller the amount of work they accomplish, the greater the amount of employment there will be for other men, it is utterly valueless. . In the facts that Co-operation tends to increase each worker's productive power, and that it reduces the number of men who are merely employed to over-see others, thereby cheapening production, I recognise one of the great merits of the system. It cannot be too strongly emphasised, for there is wide-spread misconception on this point, that work begets work, that prosperity in one industry re-acts favourably on other industries, and so stimulates demand and

1 Presidential Address of Earl Grey to the Labour Co-partnership Association. 1912. 


\section{TRADE UNION OBJECTIONS}

consequently employment. Increased production and cheapened commodities also benefit the community generally, and more especially the working-class consumers. ${ }^{1}$

To the third objection we can only reply that the aims of Trade Unionism and Co-partnership are to a great extent substantially the same. Both are devices whereby to improve the condition of the wage-earners. When the Unions therefore find peaceful relations existing between employer and employed, and their men receiving a fair day's wage for a fair day's work, with a share in the profits to boot, it is but natural that there should be but little need in these cases for collective bargaining, or for attempting to redress wrongs. Trade Unions have, however, other functions than those of resisting or opposing employers. They are capable of being transformed and modified to carry on and develop the more social side of their work. Liberation from one responsibility gives them the freedom to initiate a wider policy. If the mutual interests of employer and employed were once to gain due recognition in the Trade Union world, the zeal which has in some instances been directed to restricting output and hampering trade might well be diverted to encouraging skilled craftsmanship, and raising the general efficiency of labour.

1 Professor Marshall, in his statement of the conditions under which Trade Unions may permanently raise general wages, writes : "They must strive to develop the great stores of business power and inventive resource that lie latent among the working classes, so tbat production being economical and efficient, the National Dividend may be large; and that, business power being cheap, and the share going as Earnings of Management being relatively small, that which remains for wages may be high." Elements of Economics of Industry. Alfred Marshall. p. 397. (Third Edition, 1912.) 
The Socialist has no good word for Co-partnership. His firm conviction that a complete remodelling of the industrial system is necessary alienates his sympathy from attempts to unite the opposing forces in society as it is at present constituted. To reconcile the wage-earner with his employer under the capitalist system is merely, from his point of view, to retard the day when the State is to take control of all the means of production, and private ownership is to cease, and in fact to oil machinery which is destined to be relegated to the scrap-heap. As a saner and more moral view of the respective "rights" of Capital and Labour gains ground than that which exists in the modern industrial world to-day, it seems probable that the Spirit of Association will be increasingly manifested in various forms of Co-partnership. The fusion of the interests of employer and employed, which is the raison d'être of all efforts to promote Co-partnership, makes an appeal not only to industrial morality but to common-sense. The introduction of a better social spirit, which is admittedly the result of Co-operative profit-sharing, does away with the friction, bitter feeling, and waste which are the morally and economically harmful results of the conflict of warring interests. Co-operation is a vital, permanent, and constructive force; whereas strife is sterile, impermanent, and destructive.

By means of Co-partnership the forces of good-will are placed at the service of industry. A new energy and interest in the work is infused into the employees. Production is stimulated, the desire to restrict output disappears, and indeed, were the movement to make an extensive growth, it may be confidently predicted that the national production would be very largely increased. 
It is impossible to study the history of the development of the two great French Co-operative industriesthe Maison Leclaire, and the Society of the Familistère founded by Godin at Guise-without realising what enormous possibilities such businesses afford for inspiring mutual trust, for heightening the standard of business and social morality, and for promoting the welfare and the security of the workers.

If the Industrial Revolution added to the material prosperity of our country without securing a just distribution of the wealth, there is every reason to hope that the steady growth of Co-partnership in Great Britain will ultimately prove to be one of the means of promoting a more general well-being and a more wholesome division of the national dividend. It rests with the most public spirited of our employers to tackle this problem patiently, yet boldly. They must realise that the future welfare of the nation depends upon an antidote being found to the poison which produces the phenomena of labour unrest. There can be no higher work of citizenship at the present time than to rule industry as one who serves. 


\section{CHAPTER XIV}

\section{TRADE UNIONS (1700-1830)}

THE CAUSES WHICH PRODUCED TRADE UNIONS

I have endeavoured in the past chapters to show how great are the services which the Friendly Societies have rendered to the working-man in his wage-saving capacity. We have seen something of the aid which the Co-operative Store movement has given him as a wagespender. We have now to attempt to examine the history and achievements of Trade Unionism and their relation to the worker as a wage-earner. It will be seen that three main strands have thus formed as it were one rope, by means of which industrial democracy has striven to advance on the firm ground of economic stability. Each strand of the rope has gained strength from the other two: "A threefold cord is not quickly broken." Each of these three forms of voluntary association has grappled with problems of great complexity, and has had its own work facilitated by the achievements of the two with which it has been interwoven.

A Trade Union has been defined by the interpreters 


\section{CAUSES OF COMBINATION}

par excellence of the aims and methods of Trade Unionism as a continuous association of wage-earners for the purpose of maintaining or improving the conditions of their employment. ${ }^{1}$ The first combination which these authors recognise as falling within the terms of this definition came into existence at the beginning of the eighteenth century. Trade Unionism, therefore, though it received a mighty impulse from the introduction of the factory system, does not owe its first inception to the invention of machinery. It had made its appearance some sixty years before the great changes which were wrought by the Industrial Revolution had begun to make themselves felt.

The main causes which contributed to impel the wageearners to combine in a more effectual, enduring, and vigorous manner than had been the case when they formed their first ephemeral journeymen's societies require brief description.

The primary factor which produced Trade Unionism was the large increase in the number of permanent wage-earners. The rapidly growing class of artisans instinctively followed the universal tendency which draws men to establish new forms of association as new requirements arise. The growth of industrial capital, and the expansion of trade from a local to a national area, broke down the ringed fence of Gild restrictions, and served to create industries which were conducted on a larger scale. The separation of the functions of employer and employed, which the growth of more extensive forms of manufacture implied, tended to check the possibilities of advancement from the status of journeyman to small master; and consequently to increase the number of

1 History of Trade Unionism. S. \& B. Webb. p. I. 
men who formed a class of permanent wage-earners. This class cleavage, which widened so persistently from the beginning of the eighteenth century, had existed within the industrial system to some extent from the fourteenth century, and had already proved an incentive to the journeymen to form temporary combinations. ${ }^{1}$ During the sixteenth and seventeenth centuries the journeymen were, however, almost inarticulate, whilst the industrial struggle was mainly waged between the small masters and the merchant employers. ${ }^{2}$ Meanwhile forces had been silently at work which served to quicken associative energy in the journeyman class, and which gave birth to Trade Unionism in the reign of Queen Anne.

Economic circumstances were tending to raise the small master of more than average ability to a position of greater importance, as the employer of a considerable number of hands, and an organiser of more intricate methods of production. The modern "captains of industry" began to emerge from their fellows in some parts of England during the seventeenth century. Wealthy master clothiers arose in the west country who conducted every process of cloth making, and employed a separate class of operatives at each stage of the work: "Buying the wool at one of the market towns, the capitalist clothier gave this to one set of hand-workers to be carded and spun into yarn in the village households. The yarn was passed on to another set-the hand-loom weavers - to be made into cloth in their cottages. The cloth was then "fulled" at the capitalist's own mill (usually a water-mill) and again given out to be "dressed" by a new set of hand-workers, after which it was ready

1 See pp. $72-77$.

2 Industrial Organisation. G. Unwin. p. 126. 
to be packed in the warehouse, and despatched to Bristol or London for shipment or sale." 1 Obviously when industry had assumed so extensive and complicated a form the separation of functions between actual manual work and the task of organising the business was absolute. The opportunities for the journeymen employed in such manufactures of rising out of the position of life-long wage-earners were negligible. One further illustration in proof of this point may be given. The typical journeyman tailor in London and Westminster was by the beginning of the eighteenth century confined to a permanent class. He was employed intermittently by mastertailors, who paid high rents for shops in fashionable quarters of the town. He was recruited from the " houses of call" in times of pressure, set to work with a dozen or more of his confrères, and turned adrift when his services were no longer required. ${ }^{2}$ It was in trades such as these that Trade Unionism responded to the demand for a new form of association.

The barriers which were placed across the path to mastership were not the sole cause which contributed to swell the ranks of wage-earners. A large number of small masters, who were less able or less fortunate than their fellows, were driven from the field as employers or independent producers, and were forced to content themselves with earning a livelihood as mere journeymen. This recruitment from a higher class to a lower was not without advantages. The small masters brought traditions of vigorous associative effort, and played an important part in promoting the earliest forms of Trade Unionism. The journeyman class thus gained in mental

1 History of Trade Unionism. S. \& B. Webb. p. 28.

2 Ibid., p. 26. 
calibre, force, and co-operative character, from the influx of small masters into their ranks. ${ }^{1}$

The disappearance of Gild restrictions, and the disregard of the Tudor and Stuart statutory regulation of industry, brought certain consequences to the wageearners, which also operated to produce democratic organisation in Trade Unions. The resistless forces which contributed to create more complex forms of industry rendered the famous Statute of Apprentices practically null and void. By this Act Elizabethan statesmen had attempted to fix the wages and the length of the working day, by means of rulings of the Justices of the Peace, in practically every trade. The object had been to secure regularity of employment for masters, apprentices and journeymen throughout Tudor England. Subsequent laws, and countless Gild restrictions, had served to limit the number of apprentices, and had so protected both journeymen and masters from an inflow of men into the crafts.

The question of the limitation of apprentices was felt by the wage-earners of the eighteenth century to be of vital importance in the new and larger types of industries. The interpretation of the Statute of Apprentices, which confined its application to cities, towns corporate and market towns, and to the trades which were in existence in Queen Elizabeth's reign, rendered it quite inoperative in many industries and in many parts of the country. It is also noteworthy that even where the provisions of the law were still applicable, they were often flagrantly disregarded. The small masters were generally in favour of limiting the number of persons entering the crafts, the journeymen were equally anxious to protect themselves

1 Industrial Organisation. G. Unwin. p. 200. 
from competition. The fact that labour was still very stationary, and that both enterprise and opportunities to emigrate were deficient, rendered each man exceedingly anxious to safeguard his chances of employment in his own village, town, and trade.

The large employers, on the other hand, had, they believed, nothing to fear and much to gain from the employment of cheap labour. They therefore constantly showed a tendency not only to keep more than the permitted number of apprentices, but also to employ boys who had not been bound. ${ }^{1}$ We must confine ourselves to one illustration of the conflicts and conditions which this ever-growing diversity of interests produced.

The history of the trade of framework-knitting, which has been given at some length by Dr. Brentano, is especially interesting as affording a clear example of the "embryo factory" system and the domestic system of industry existing side by side. We may also trace the final absorption of the smaller home producers or small masters into the ranks of permanent wage-earners, and the consequent formation of a Trade Union. By the beginning of the eighteenth century the capitalist masterstockingers had ceased to limit the number of apprentices, and it is even recorded of one employer that he constantly kept twenty-five apprentices to one journeyman. The practice had also arisen among the parish authorities of giving premiums to these capitalist manufacturers to induce them to employ their poor. They frequently paid bounties to the amount of $f_{55}$ for every boy taken from the workhouse. The result of this subsidised labour on the knitting industry was that the adult workers, when their time of apprenticeship had expired, were

1 Industrial Organisation, G. Unwin. p. 117. 
reduced to a state of destitution. Moreover, the owners of frames who worked in their own homes were ruined by the competition of the larger industries, just as the homeworkers of succeeding generations were ruined when trade after trade adopted the use of machinery. Wages fell, and employment became scarce. The workers therefore petitioned the Company of Framework-knitters, which had been incorporated under a charter of Charles II, and was under a definite legal obligation to limit the number of apprentices, to redress their grievances. The Company refused to do so and a riot of workmen ensued. About roo knitting frames were destroyed, and both masters and apprentices were soundly beaten by the insurgents. The masters submitted, and promised to observe the ordinances of the charter for the future. They continued, nevertheless, to take parish apprentices, until the trade was so overstocked with journeymen that a serious outbreak of riots again took place. In 1727 , in consequence of this recurrence of violence, an Act was passed which made the offence of frame-breaking punishable by death. The volume of trade grew, the employers prospered, and the tussle continued. Meanwhile the home-worker lost the ownership of his frame, and a system arose under which he either rented a frame from a small capitalist, or from a manufacturer who gave out the materials to be worked up in the operative's own home, just as the small employer conducts industry in some trades in East London to-day. The home-worker thus lost much of his independence, and also the possession of the products and instruments of his labour, and became a wage-earner. During the first half of the eighteenth century, the trade retired more and more from London to Nottingham, and there the same evils were manifested. 
The workers continued to suffer from a constant influx of boys, girls and non-apprenticed workers. Finally, in I 778, the knitters, supported by the small masters, who had failed to hold their own as independent producers, formed a durable Trade Union, called the "Stocking Makers' Association for Mutual Protection in the Midland Counties of England," for the purpose of regulating apprenticeship, as legal restrictions had ceased to be binding. ${ }^{1}$

It will be clearly seen from the foregoing account that the era in which the conditions of employment and the conduct of trade were fixed with elaborate precision had passed away before any theories had been formulated as to the means by which competition could be bent to man's uses. The swing of the pendulum, from an exaggerated belief in the power of statutory regulation to supervise industry, to a helpless acquiescence in the doctrine of laisser-faire, was therefore one of the causes of the morass of poverty and suffering, into which a section of the population was plunged, at the close of the eighteenth century. It was as though some lake among the hills had been afforded an outlet, whereby to irrigate the plains beneath, before engineers had made the channels through which the waters were to flow, or the locks by which they were to be bound. Disaster was inevitable, and the lesson had to be slowly and painfully learnt that competition is a force which, so long as human nature remains as it is, requires to be definitely checked.

\section{THE FIRST DEVELOPMENTS OF TRADE UNIONISM}

The operatives who were suffering in this manner made repeated efforts to obtain a renewal of the statutory

${ }^{1}$ See English Gilds (Brentano's Essay, pp. clxxix-clxxxi) and History of Trade Unionism. S. \& B. Webb. pp. 32, 33, 45. 
regulations which they believed to be in their interests. Parliament in former years had so often exercised its powers to secure a "convenient" livelihood for the craftsmen that the habit of generations asserted itself and the men naturally appealed to have their wages fixed by the Justices of the Peace as in the past. Industry had outgrown mediæval restrictions and the workcrs' appeals were made in vain.

The growing faith in the doctrine of laisser-faire, which resulted in the workmen being left to shift for themselves, had one great advantage-it afforded the comparative freedom which alone made it possible for the wage-earners to seek strength in union, and to build up associations based on independence and self-help. Before the enactment of the Combination Laws at the close of the eighteenth century, the journeymen were enabled to lay the first foundations, upon which the great structure of Trade Unionism was gradually reared, by means of the establishment of "houses of call," and a system of "tramping tickets" wherewith to assist members in search of employment. ${ }^{1}$

The "houses of call" were public-houses, where the men were able to seek information, which became the centre of trade organisations. The increasing irregularity in employment, coupled with the growth of the means of communication throughout the country, gradually induced the journeymen to travel further afield in search of work than in the days of local trading. Consequently, systematic arrangements were made for the relief of these "tramps" by their fellow-workers in the towns through which they passed. ${ }^{2}$

1 Industrial Organisation. G. Unwin. p. 227.

2 History of Trade Unionism. S. \& B. Webb. p. 23. 
The wool-combers had evolved an extensive system of mutual help of this nature by the middle of the eighteenth century. In $174 \mathrm{I}$ it was stated that: " the wool-combers support one another, insomuch that they are become one society throughout the kingdom. And that they may keep up their price, to encourage idleness rather than labour, if anyone of this club is out of work, they give him a ticket and money to seek for work at the next town where the box-club is, where he is also subsisted, suffered to live in certain time with them, and used as before; by which means he can travel the kingdom round, be caressed at each club, and not spend a farthing of his own or strike one stroke of work. This has been imitated by the weavers also, though not carried through the kingdom, but confined to the places where they work." 1 It is important to notice that this passage indicates that Friendly benefits were already being consciously applied to trade purposes. The men had realised that only by relieving their unemployed members could they withdraw them for a time from the labour market, and so prevent them from accepting work on terms which would prove injurious to their brethren-in fact, undercutting the price of labour.

Permanent organisations arose in various ways. The early history of the Trade Unions is closely linked with that of the Friendly Societies. Many a village club which originated merely for purposes of mutual help in case of sickness, or to provide for burial, drifted unconsciously into a society with trade purposes. When a club of this kind was composed entirely of men engaged in one trade, questions of wages and employment naturally aroused

1 A sbort Essay upon Trade in General by a lover of bis Country. London, $17+$ I. Cited by S. \& B. Webb. Economic Review, October, I 896 . 
corporate interest. Societies which were formed by men of migratory habits, or who followed a dangerous calling, almost inevitably became Trade Unions. Strikes, social gatherings, meetings to formulate petitions to be laid before the House of Commons, all served to give an impulse to the wage-earners to establish permanent associations. ${ }^{1}$

A curious illustration of the attitude of the employers to the members of these early societies is afforded by a master's advertisement in a newspaper for " hands." It included the proviso that applicants were "not to be subject to the House of Call, as none would be employed but such as called at the master's houses and are free from all combinations." The journeymen in this case appealed to the public whose sympathy was with them, and they defended their "House of Call" as an ancient custom which obtained both in London and other capital towns. The sequel to the dispute was that the strikers united to form a primitive co-operative workshop, and announced their intention of carrying on the trade themselves in all its branches, adding that: "good workmen, and those only who applied at their House of Call at the Coach and Horses in Bell Street, would meet with good encouragement." 2

As the eighteenth century progressed Trade Unions, in spite of the opposition of the masters, grew and multiplied. The journals of the House of Commons from the middle of the century abound in petitions of employers against workmen's combinations, and counter-petitions presented by organised bodies of journeymen. ${ }^{3}$ The movement grew even more rapidly as the century drew

1 History of Trade Unionism. S. \& B. Webb. pp. 22, 23.

2 History of Co-operation. Holyoake. Vol. II, p. 247.

\& History of Trade Unionism. S. \& B. Webb. p. 21. 
to a close. The effects of the Industrial Revolution were beginning to be felt in the manner which I attempted to describe in Chapter VII. The competitive pressure which was exercising so harmful an influence on the standard of life in factories, mills, and mines served to stimulate the activity of Trade Unionism. Societies sprang into existence with such rapidity amongst the factory population that the governing classes were alarmed, and Act after Act was passed with the object of checking the organisation of labour. Finally, in 1799, a comprehensive Statute was enacted which, together with an amending Act of the following year, rendered every Trade Union an unlawful association "in restraint of trade."

These Combination Laws were, as we have seen, injurious to the Friendly Societies and stunted the growth of the Affiliated Orders, but they exercised a yet more harmful influence on the Trade Unions. They struck at the very roots of their existence, rendering any attempt to treat collectively with the masters a criminal offence. Men were forbidden to combine with others to advance their wages, or decrease the hours of work, or in any way to affect or control those who carried on any manufacture or trade. Delinquents might be hailed before a Justice of the Peace, and committed to the common gaol for any time not exceeding three calendar months, or kept to hard labour in the House of Correction for a term of two calendar months.

Though the masters did not make any general attempt to stamp out Trade Unionism, the powers of the law were often invoked by employers who found themselves inconvenienced by the demands of the men. It is true that the masters were also prohibited from combining, 
but their need to seek strength in union was obviously not comparable with that of the operatives. The fact, too, that justice was not administered with impartiality afforded a constant source of irritation to the men. ${ }^{1}$

The efforts of the Georgian House of Commons to quench the Spirit of Association failed signally. The Unions, far from being stamped out, made a continuous though secret growth. Some trade combinations were formed under the cloak of Friendly Societies, a deception for which the attempt to frustrate a wholly legitimate political instinct was responsible. The laws which had rendered innocent actions criminal offences had a profound effect in debasing the character of the working classes. The men who formed Unions knew that they were acting lawlessly, and often did not hesitate to misuse the forces of association. Those who remained outside the Unions felt themselves to be the victims of the industrial changes, and also took part in acts of violence. Strikes were organised by secret societies, attempts were made to blow up mills, which were sometimes successful, and machinery was destroyed. Apalling means were sometimes used to force non-unionists to join these illegal societies. The men who refused to become members of the Unions were regarded as traitors to their class. Vitriol throwing, which resulted in blindness, and even murder, were not unknown, as the outcome of the bitter hatred which was engendered between the Unionists and their fellow-workmen. The Trade societies of this period have been described by authorities on working-class association, as "active, though generally

1 "During the whole epoch of repression, whilst thousands of journeymen suffered for the crime of combination, there is absolutely no case on record in which an employer was punished for the same offence." History of Trade Unionism. S. \& B. Webb. p. 64. 
ill-managed, secret in their rules and deliberations, and too often tyrannical in their proceedings. In nearly all of them there was a tendency to violence. Union men habitually refused to work with non-union men. Knobsticks, as men who worked under price were called, were often maltreated; murder sometimes being the result." 1

While this is probably a fair description of the large majority of the Unions of the period; of the struggles which were taking place in the unskilled trades; and of the prevalence of the indefensible custom of victimising non-unionists, the higher grades of workmen, such as the compositors, hatters, and ship-wrights, were steadily building up stable societies which foreshadowed the great Trade Union movement which was yet to be.

FRANCIS PLACE AND THE COMBINATION LAWS.

In about the year I8I4, Francis Place, the celebrated master-tailor of Charing Cross, set to work to obtain the repeal of the laws which were rendering practically all forms of working-class association illegal. He had been deeply moved by the prosecution of some journeymen compositors, who were in the employment of the $T$ imes, in I8Io. These men were charged with the crime of belonging to a combination and of having taken part in a strike. The Common Sergeant of London, known to fame as "Bloody Black Jack," painted the crimes in the darkest colours, and passed sentences upon them of terms of imprisonment which varied from nine months to two years. The iron had entered into the soul of Place, in previous years, when he had himself been a black-listed journeyman, and had faced despair, unemployment and semi-starvation. He had lived for

1 Progress of the Working Class, 1832-1867. J. M. Ludlow and Lloyd Jones. p. 22. 
a time in constant danger of arrest as the secretary of a Trade Society. The just and moderate denunciation of the Combination Laws which he published in pamphlet form in 1825 was based on his own personal experience of the evils which the repressive laws brought in their train. "If keeping down wages in some cases by law was a national good, if the degradation of the whole body of the working people by law was desirable; if perpetuating discord between masters and workmen was useful; if litigation was a benefit; if living in perpetual violation of law was a proper state for workmen and their employers to be placed in, then these laws against combinations of workmen were good laws, for to all these did they tend." 1

Place had passed through the very school which tends to make reckless leaders. It is the more creditable to him that his great influence was always exercised on the side of law and order. He continually counselled moderation and vigorously upbraided the extremists of his time. His description of some of the leaders whose aim was to stir up strife is worth recalling at the present day: "Some of these men were remarkably ignorant, but fluent speakers, filled with bitter notions of animosity against everybody who did not concur with the absurd notions they entertained, that everything which was produced belonged to those who, by their labour, produced it, and ought to be shared among them; that there ought to be no accumulation of capital in the hands of anyone to enable him to employ others as labourers . . Most of these men were loud and long talkers, vehement, resolute, reckless rascals." 2

1 Life of Francis Place. Graham Wallas. pp. 199, 200.

2 Ibid., p. 273. 
The stirring story of Place's efforts on behalf of the Unions has been admirably told in his recent biography. Francis Place was a past-master in the art of wire-pulling, of drafting Bills and resolutions, and of convincing men of the justice of his contentions. With astute diplomacy he kept studiously in the back-ground, planning in the parlour of his tailor's shop the methods of attack by which the small force was to gain the victory. His manuscripts, which are preserved in the British Museum, show not only that he was the deus ex macbina throughout the whole campaign, but that he fully realised the extent of his own political influence. He was content to play a subordinate part while others reaped the credit, for he recognised that by doing so his ends would be best attained.

He collected eight large volumes of evidence relating to the labour question from all parts of the country, to serve as a weapon for his campaign. One of the great difficulties he encountered was that the workmen were suspicious of all efforts made on their behalf. Tact and persuasion, however, did much both to overcome their distrust and to convert public opinion.

A Committee of Inquiry was ultimately appointed by the Government. Mr. Joseph Hume, M.P., who worked in close collaboration with Place throughout the whole proceedings, was appointed chairman. The result of the careful preparation of the evidence which was laid before the Committee was that a Bill to repeal all the Combination Laws was rapidly passed through the House in 1824 without either debate or division. The proceedings had been conducted so quietly, and the fact was so little realised in the country generally, that it is recorded that some cotton-weavers were sentenced to 
imprisonment for combination some weeks after the laws against that offence had been repealed. ${ }^{1}$

It is curious to remember that Place, when his object was thus accomplished, forecasted that the Trade Unions would gradually dwindle away. He thought that combinations, save "for particular purposes under peculiar circumstances," would cease to exist. "All will be orderly as even a Quaker could desire."2 Events quickly proved that this theory was based on sand. The country was enjoying a time of exceptional prosperity, and the workmen promptly seized the favourable opportunity to strike, and throughout the country masters and men were shortly engaged in trade disputes. Place wrote and forcibly remonstrated with the cottonweavers of Glasgow, but he was unable to convince the liberated Unions of the wisdom of exercising restraint. The trouble in the shipping trades, and the unreasonable demands of the Trade Unionists of Sheffield and Dublin, thoroughly roused the employers, and when Parliament met in 1825 they had so influenced the President of the Board of Trade that the new liberty to combine was placed in very serious jeopardy. A Committee was appointed by the House of Commons to report upon the working and effect of the legislation of the previous year. The members of the Unions, fearful of losing their newly-won freedom, acted with vigour. They formed committees, drafted petitions, and sent witnesses to London to oppose the re-enactment of the Combination Laws. The result was on the whole as satisfactory as could be expected, and the House of Commons passed an Act in 1825 (6 Geo. IV., c. 29) which though it nominally

1 History of Trade Unionism. S. \& B. Webb. p. 92.

2 Life of Francis Place. Graham Wallas. p. 217. 
re-enacted the Combination Laws, made a definite exception in the case of associations which were formed for the purpose of regulating the wages and the hours of labour. ${ }^{1}$

The position in which the Unionists found themselves after the passing of the Act was this : they had gained the right of uniting to determine under what conditions of hours and wages they would consent to work, they had also acquired the right to collectively withhold their labour from the market. Serious injustices, however, remained. The Legislature still drew a severe distinction between master and servant, and master and workman. In breaches of contract, for instance, the employee was dealt with by the criminal law, whereas the master's offence was merely a civil one. A workman was liable to be arrested and imprisoned for breach of contract before his case was tried. If he was convicted and sentenced by a Justice he had no power to appeal. All persons were liable to a maximum punishment of three months' imprisonment, with hard labour, who should by violence, threats, or intimidation, molestation, or obstruction, endeavour to do, or aid, abet, or assist in doing, or endeavouring to do, any of a series of things inconsistent with freedom of contract which the Act enumerated or defined. For many years after I 825 , the law dealt severely with "offences" such as the prohibition of piece-work, or the limitation of apprentices, which were described as "conspiracy" among workingmen for trade purposes. A further disability under which the Unions still laboured was, that they had no means of protecting their funds from dishonesty or plunder on the part of their members or officials.

1 History of Trade Unionism. S. \& B. Webb. p. 96. 
The Trade Unions, when once legalised, instead of dwindling away as Place had anticipated, grew rapidly. Societies were founded, some of which had but a brief existence, in almost all industries in the country. The widespread commercial disaster, however, which took place at the close of the year 1825 , dealt a severe blow to the attempts made by the Unions to secure better terms for labour. Collective bargaining was of no avail, strikes failed, and the Trade Societies found themselves quite powerless to stop the downward trend of wages. Riots again broke out, and we read that in 1829, "Manchester cotton mills were attacked, windows were broken, machinery was demolished, and one or two of the mills were burned. At Rochdale the weavers broke into the factories, destroying looms and other machinery. Fifteen of the rioters were captured, and on an attempt to rescue being made, the military fired and killed six persons." 1

The Trade Unions were receiving the bitter lesson that though the strike may prove a justifiable and a necessary weapon under certain circumstances, it is rarely successful when used to resist a reduction in wages.

1 Progress of the Working Class, 1832-1867. J. M. Ludlow and Lloyd Jones. p. 23 . 


\section{CHAPTER XV}

\section{TRADE UNIONS (1830-I880)}

\section{THE FIRST " NEW UNIONISM"}

IN 1830 trade revived to some extent, and the first symptoms of a new policy made their appearance in the Trade Union movement. An initial effort was made in that year to form one universal trades association for the entire kingdom. The futility of sectional strikes, as a means whereby to improve the conditions of labour, seems to have been gradually gaining recognition. A conviction was growing in the Trade Union world that it was necessary to link together the whole of the forces of labour by means of a central society, with a separate organisation for each trade. A "New Unionism" and an "Old Unionism" were thus existing simultaneously within the movement. The Old Unionism was represented by the trade clubs, the origin of which we described in the previous chapter. The "New Unionism" was the result of the ambitious project to include all manual workers in one vast organisation, and all the members of each individual trade in a national society. ${ }^{1}$

1 History of Trade Unionism. S. \& B. Webb. p. 103. 
The National Association, as this pioneer effort to form a "Trades Union" " 1 was named, is said to have succeeded in enrolling 100,000 members. Though it gave some effective support to factory legislation, the lack of funds fettered its activities, and the life of the federation was of brief duration.

Other attempts were, however, made to organise the forces of labour on a large scale. A Builders' Union, for instance, was formed which aimed at uniting all the operatives who were engaged in the seven building trades throughout the country. Interesting records are in existence relating to this Union, which show that the society developed an elaborate ceremonial which contained masonic features. The initiation rites included an opening prayer, religious hymns sung at intervals, and questions and responses framed in quaint doggerel. Candidates were blindfolded and admitted into an inner chamber, where a skeleton, a drawn sword, battle-axes and other mystic properties, added to the solemnity of the occasion. The new members were forced to take a solemn oath of loyalty and secrecy. ${ }^{2}$ The subterfuges to which Trade Unions had been driven when their mere existence was an offence in the eyes of the law had fostered the custom of binding the members in this manner by oath to secrecy and obedience. There is little doubt that the retention of these rites was a source of alarm to the Government during the years when the fear of revolution was ever-present, and constituted one of the reasons for the strong prejudice which the " Trades Union" movement aroused.

1 A "Trades Union" is a combination of different trades, as distinguished from a "Trade Union," which consists of members following one craft.

${ }_{2}$ History of Trade Unionism. S. \& B. Webb. p. 113. 
In 1833 Robert Owen threw himself with energy into the "Trades Union" cause. His enthusiasm, his commanding personality, and his resolve to regenerate mankind, and that at lightning speed, captured the imagination of the workers. His dream for organised labour was substantially that which has inspired the "myth" of the Syndicalist. The workers were to assume control of the industries of the country, and were to become both the owners and directors of the means of production. The Trade Unions were to develop into national companies to carry on all forms of manufacture. Any hesitation on the part of the governing class to conform to the new programme was to be overcome by a "General Strike." Emancipation was to be won by paralysing society. When every machine had been brought to a standstill, and every manual worker had laid down his tools, it was thought that landlords and capitalist employers would invite the workers to carry on the necessary industries, and that they would be driven to accept any terms which the combined forces of labour should demand. Thus the operatives were to gain the ownership of the cotton factories, the miners of the mines.

Owen's promises of a New Moral World, William Cobbett's indictments of the capitalist system, the failure of the Reform Bill of 1832 to enfranchise the wageearners, all served to foster discontent and to stimulate democratic associative action. In I834 there was a rush towards organisation. It is stated that in the course of a few months half a million members were enrolled in the great "Trades Union." Even agricultural labourers and women, who are proverbially among the classes which are the least ready to organise, were drawn within the society by the influence of the Spirit of Association. The 
labourers had bitter grievances, they were ill-paid and ill-housed, and their discontent had found frequent expression in riots, machine breaking and rick-burning.

In the spring of 1834 Trade Unionists received a terrible blow in the trial, conviction, and iniquitous sentence which was passed upon six Dorchester labourers, who were forming an agricultural branch of the central society. The famous six labourers were condemned to be transported for seven years for the crime of administering unlawful oaths. The working-classes were deeply stirred. An immense demonstration took place in the Copenhagen Fields on April 2 Ist, 1834, and a procession of working-men made its way to the Home Office. Francis Place performed the office of peacemaker behind the scenes. He urged the men to keep the law relating to petitions, and persuaded the Government, which was genuinely alarmed by the menace, as they regarded it, of federated labour, to allow the procession to take place. "There will be an immense assemblage of people," he wrote, "but if they be let alone and no display of a provocating nature be made against them, all will go off quietly." The procession was allowed to pass unhindered, and the following day Lord Melbourne consented to receive a small deputation of the men. No concession was made to its demands, and the Cabinet decided to carry out the sentence. The reason for the adoption of this relentless attitude was, as Lord Brougham admitted to Place four years later, lest they should have been thought to have taken the merciful course through fear. ${ }^{1}$

The convicted men were subsequently pardoned, but they had already been transported to Botany Bay, and

1 Life of Francis Place. Graham Wallas. p. 357. 
some of them did not even hear of their pardon until several years later. They would indeed probably have remained in ignorance of their claim to release until the expiration of their sentence, had they not chanced to see an English newspaper in the colony, at the governor's own house. ${ }^{1}$

This gross perversion of justice fed the fierce flames of class animus, and afforded a stimulus of an entirely unhealthy nature to Trade Unionism. Lawless outrages were again conspicuous features of the movement. The Cotton Spinners Union attained an unenviable notoriety from the trial of five Glasgow spinners for conspiracy, violent intimidation, and murder. The evidence which was produced served to prove that the Union had initiated a reign of terror, and that there had been actual violence if not murder. ${ }^{2}$ Extensive strikes took place in several trades, by means of which, however, even less was gained in the time of prosperity than had been accomplished in the previous years of commercial depression.

By the end of the summer of 1834 , the Grand National Consolidated Trades Union was discredited amongst the workers, and was tottering to its fall. The federal organisations which had been formed throughout the country were also breaking up. ${ }^{3}$ The short period of ardent faith in "New Unionism" was closed, and the wage-earners had again to look for help to their local trade clubs. The movement had been promoted by Socialists and idealists, whose "reach" had exceeded their " grasp," and whose genuinely disinterested though misguided efforts were rewarded with discredit and failure. It was not until Trade Unionism set systematically to

1 The Conflicts of Capital and Labour. George Howells. p. 135.

2 History of Trade Unionism. S. \& B. Webb. p. 154.

3 Ibid., p. 137. 
work with humbler and more practical aims that it succeeded in obtaining any real advance in the conditions of labour.

\section{DEVELOPMENT OF A WISER POLICY}

From about the year I 843 a more practical spirit began to pervade the Trade Union world. Fantastic schemes for remodelling society by revolutionary methods were laid aside, and the leaders, inspired by new aims, began to direct their attention to building up powerful organisations, on the basis of a sounder trade policy than resulted from a mere reliance on ephemeral strikes. The wiser counsellors had two factors in their favour. First, there was a natural reaction from aggressive methods which had miserably failed, and secondly a trade cycle began in which the equilibrium of production and employment was more steadily maintained. The diminution in the fluctuations which had so cruelly disturbed the rates of wages in previous years, afforded the required opportunity for associative effort to develop a calmer policy.

The so-called " Old Unions" which came into existence during this period possessed carefully planned constitutions. The power which the local branches had formerly possessed of declaring strikes on their own initiative was withdrawn. Questions in dispute were submitted to the executive of the whole society, or even to a vote of all the branches. This gave time, the great harbinger of peace in trade disputes, in which the grievances might be adjusted. Large funds were raised by increased contributions, and Friendly Society benefits were afforded which tended to aid the Unions in their work of raising the standard of life by peaceful rather than belligerent methods. An extract from a Fortnightly Circular of 
I 845 of the Stonemasons' Central Committee serves as an indication of the calmer and more reasonable attitude which the societies were adopting. The members were exhorted to keep from the dangerous practice of striking : "Keep from it, as you would from a ferocious animal that you know would destroy you ... We implore you brethren, as you value your own existence, to avoid, in every way possible, those useless strikes. Let us have another year of earnest and attentive organisation; and if that does not perfect us, we must have another ; for it is a knowledge of the disorganised state of working-men generally that stimulates the tyrant and the taskmaster to oppress them." The Flint Glass Makers' Magazine similarly condemned strikes as having been the bane of Trade Unions. ${ }^{1}$

The adoption of a moderate policy did not imply any slackening of effort to secure improved conditions of labour. The National Association of United Trades, which was founded in 1845 as a result of the great revival in Trade Unionism, declared its main object to be the promotion of the well-being of the associated trades by mediation, arbitration and legal proceedings. It also undertook to further all measures, political, social, and educational, which were intended to improve the condition of the labouring classes. ${ }^{2}$

The Unions of the period also made strenuous efforts to diminish the number of workmen entering the trades, in the hope that a diminished supply of labour would serve to raise wages. Many of the large societies started emigration funds, wherewith to send some of their members to other lands, where the strain of competition

1 Cited in History of Trade Unionism. S. \& B. Webb. p. 181.

1 Ibid., p. 169. 
was less severe. Several Unions also adopted a vigorous policy of attempting to strictly limit the number of apprentices. An exhortation in the Flint Glass Makers' Magazine- "Look to the rule and keep the boys back; for this is the foundation of the evil, the secret of our progress, the dial on which our society works and the hope of future generations "-illustrates the attitude of many associations. The typical societies of this period, such as the Amalgamated Society of Engineers, which was founded in $185 \mathrm{I}$, also endeavoured to improve the conditions under which their men worked by agitating against piece-work and overtime. Though strikes were less frequent during this more constructive period of Trade Union activity, there was still great dissatisfaction with the existing state of the law. Prosecutions and convictions, on the charge of "conspiracy," were a perennial source of irritation to the men, who felt with reason that they were neither treated fairly by the law, nor judged justly under it. It is not surprising to find that the law respecting contracts between masters and servants was a standing grievance, when it was shown by a Committee appointed to inquire into the subject that there were about II,000 prosecutions annually in England and Scotland alone for breach of contract by employees. ${ }^{1}$

The lack of protection to the growing funds of the societies was also a source of increasing anxiety to the members. An attempt was made in the Friendly Societies Act of 1855 to give the Unions the necessary security by permitting societies "for any purpose which was not illegal" to deposit their rules with the Registrar. This provision was resorted to by many Trade Unions which

1 Conflicts of Capital and Labour. G. Howell. p. 144. 
relied on the Statutes of 1824 and 1825 that their purposes were of a legal nature. Subsequent decisions in the law courts, nevertheless, deprived the Unions of the power which they thought they had thus gained to protect their funds by registration, and a very real grievance remained. ${ }^{1}$ A great strike and lock-out of the engineers in 1852, which was followed by important strikes in Preston and Wolverhampton, brought the questions of the relations between employers and employed and the legal status of the combinations of workmen, again to the fore.

The event, however, which served more than any other to draw attention to these disputes, and which aroused considerable public sympathy on behalf of the workmen, was the builders' strike and lock-out which took place in London in $1859 .{ }^{2}$ This dispute originated in the presentation of a memorial by the joint Committee of Carpenters, Masons, and Bricklayers requesting the master-builders to shorten the hours of labour by one hour a day. The employers first ignored the memorial and then definitely refused the request. Four individual firms were then petitioned in the same sense, and one of these firms dismissed a man who presented the memorial. This led to a strike amongst the employee's fellow-workers against his firm. Every master-builder in London employing over fifty men promptly closed his establishment, and twenty-four thousand men were thrown out of work. ${ }^{3}$ Keen interest was aroused by this dispute, and a controversy raged in the Press throughout the country with regard to the rights of Capital and Labour. Mr. Frederic

1 Prooident Societies and Industrial Welfare. E. Brabrook, C.B. p. 27.

2 Conflicts of Capital and Labour. G. Howell. p. I43.

3 il istory of Trade Unionism. S. \& B. Webb. p. 211 . 
Harrison championed the cause of the men, and funds were contributed to assist the strikers. The employers not only refused to recognise the Unions, but the Central Association of Master Builders revealed their intention of stamping out all combinations. A resolution was passed that "No member of this Association shall engage or continue in his employment any contributor to the funds of any Trades Union or Trades Society which practises interference with the regulation of any establishment, the hours or terms of labour, the contracts or agreements of employers or employed, or the qualification or terms of service." 1 The bitter dispute ended in a drawn battle. The men did not secure shorter hours, but Trade Unionism, far from being stamped out, was greatly stimulated.

The result of these struggles, and of those of previous generations of workmen, to obtain recognition and freedom to combine was, that able Trade Union officials were beginning to emerge from among the operatives. These men had read, marked, and learned the lessons of the past, and combined a belief in a cautious trade policy with a determination to obtain reforms by political means. Working-class leaders of the type of Applegarth, Odgers, and Allen, who appeared in the arena of the industrial struggle at this time, were assets of the greatest value to the cause. Such men repudiated aggressive action and looked rather to the moral force of great reserve funds as a means whereby to succeed in collective bargaining. Odgers spoke in no uncertain tones with regard to belligerence, and declared at a large meeting of working-men at Sheffield, in 1866 , that he had no sympathy with the principle of strikes. $\mathrm{He}$ regarded them as two-edged

1 History of Trade Unionism. S. \& B. Webb. p. 21 I. 
swords, and declared them to be crimes unless prompted by absolute necessity. ${ }^{1}$

The first success which rewarded the efforts of the Trade Unionists to remedy their grievances by political means was an important one. A committee was formed to agitate for the amendment of the unjust Master and Servant Acts, and a conference of Trade Union representatives met in London in 1864 with the object of promoting legislation on the subject. Though little of immediate value was accomplished, persistent agitation resulted in a Bill being passed through Parliament at the instance of Lord Elcho in I867, which remedied the injustice of the law. From the time when this first signal victory was gained in the field of legislation, the Unions have continuously exerted themselves in greater or less degree to promote laws to improve the conditions of labour and to benefit trade associations.

The leaders who advocated a moderate trade policy were unfortunately unable to control some of the more belligerent Unions. The attempts which were made by many employers to crush the combinations by means of "lock-outs" served to incense the men, and from about I 860 Trade Unionism was increasingly active, and many Unions adopted an aggressive policy. Rumours of intimidation and violence again alarmed the public. Sinister reports were circulated from Sheffield, to the effect that secret assassination was sometimes the fate of those who incurred the wrath of Trade Unionists. Sudden and inexplicable misfortune befell the man who held aloof from the associations. "Perhaps his house was set on fire; perhaps a canister of gunpowder was exploded under his windows, or some rudely constructed infernal

1 Industrial Conciliation. H. Crompton. p. 95. 
engine was flung into his bedroom at midnight. The man himself, supposing him to have escaped with his life, felt convinced that in the attempt to destroy him he saw the hand of the Union; his neighbours were of his opinion; but it sometimes happened, nevertheless, that there was no possibility of bringing home the charges upon evidence that could satisfy a criminal court."1 The Government and the employers offered large rewards for information which would lead to the detection of the criminals, but with little result. A public meeting was held at Sheffield to protest against the crimes. Broadhead, a secretary of one of the Unions, denounced the acts of violence, and entirely repudiated the suggestion that the Trade Unions sanctioned such deeds. It was felt on all sides that a public inquiry was necessary, and the Trade Unionists were amongst those who demanded that a comprehensive investigation should be made. The result was that the Government resolved to embark upon an exhaustive inquiry, not only with regard to the outrages which had taken place at Sheffield, but upon the whole subject of Trade Unionism.

\section{THE ROYAL COMMISSION OF 1867}

When the Commission was appointed in 1867 the future looked black indeed for organised labour. The public mind was in a state of agitation and alarm. Grave charges were brought against the movement as a whole, in addition to the specific complaints from Sheffield. It was urged that industry was being driven from the country, and that Trade Unionism was injuring the character of the labouring classes. Drastic remedies

1 Short History of Our Own Times. Justin McCarthy. p. 319. 
were suggested, which had they been adopted would have involved the legal suppression of Trade Unionism. ${ }^{1}$

The investigation which was made by the Commission was a searching one, as may be judged from the fact that the results were embodied in sixteen volumes of reports. Three examiners were sent to hold an inquiry with regard to the Sheffield outrages and were empowered to take evidence on oath. The revelations which were made were of a startling character. It was found that though four-fifths of the societies in the Sheffield trades were wholly innocent, yet some of the Unions, of which the Saw Grinders was the worst example, had systematically employed the most abominable means to punish nonunionists. The outrages ranged from petty annoyance such as "rattening," to the destruction of property, mutilation, and even murder. Broadhead made a full confession of the crimes which he had instigated, and which had been paid for out of the funds of his Union. An inquiry of a similar nature was held at Manchester, and it was found that organised tyranny had been exercised there for years by the Brickmakers' Union.

This was the dark side of the picture, and it appeared at first that the prejudice which the Unions had aroused was to be amply justified. As the inquiry proceeded, however, the vast majority of the Unions were found to be entirely guiltless of sanctioning or perpetrating lawless actions. The charges of intimidation and violence, in so far as they were levelled at Trade Unionism in general, conspicuously broke down.

Mr. Frederic Harrison, Mr. Thomas Hughes, and some of the ablest and most moderate of the Trade

1 Fortnigbily Rericw, July, I869. The Trades Union Bill. F. Harison. 
Union officials produced a large quantity of evidence which did much to dispel the antagonism that the occurrence of the local outrages had occasioned. These powerful advocates were able to show how great was the value of the Friendly benefit work of the Unions. They also urged that the large amalgamated societies, far from promoting strikes, were endeavouring to allay trade disputes. The fundamental aim of Trade Unionism, as depicted by Applegarth, the Secretary of the Amalgamated Society of Carpenters, was to secure the maintenance of a standard rate of wages and standard hours for labour. The method by which the Unions strove to attain this was, he explained, by the accumulation of a sufficiently large fund to enable every member of a Union to set a reserve-price on his labour. ${ }^{1}$ It has ceased to be necessary at the present time to urge that the workingman requires the power to withhold his labour, as an alternative to accepting employment on unsatisfactory terms. The trend of opinion has entirely changed since the Unions made out their case for a claim to make bargains for their members, and to use the strength which combination alone could give, before the Commissioners of 1867 .

The employers, in giving their evidence during the inquiry, warmly contested the whole principle of collective action on the part of the workmen, and maintained that the entire regulation of industry was the affair of the employers alone. They also contended that the Friendly Society benefit work of the Unions was not actuarially sound, and that every Union was potentially insolvent. They were able to prove that some of the Unions opposed the introduction of machinery, objected

1 History of Trade Unionism. S. \& B. Webb. p. 249. 


\section{REPORT OF THE ROYAL COMMISSION 28I}

to piece-work, and made strenuous efforts to limit the number of apprentices.

The result of two years' examination of much conflicting evidence and of prolonged debate was that two reports were issued. The Report of the Commission, to which the majority of the members assented, though it was not distinctly favourable to Trade Unionism, did not admit the truth of all the charges brought against the Societies. The Commissioners strongly reprobated the practice of "rattening" and the exhibition of all forms of violence against non-unionists. They did not find that strikes were the result of Trade Unionism or that they increased with the power of the Unions. The Commissioners, therefore, recommended the legalisation of the Unions under certain conditions. They proposed that the existing law should be relaxed to the extent that no combinations should be liable for prosecution for restraint of trade, save those which were formed to do acts which involved breach of contract, or which prohibited work being undertaken by their members with any particular persons. It was also recommended that the Unions should be granted the privilege of registration. All societies were to be denied this privilege which adopted rules for restricting the employment of apprentices or opposed the use of machinery, or forbade work with nonunionists, or authorised the support of men on strike belonging to unconnected Unions.

The Commissioners were also of opinion that the funds for Friendly benefits and trade purposes should be kept entirely separate, but they did not urge that this should be made a condition of registration. The importance of this point will be developed in our examination of the functions of Trade Unionism. It must, however, be 
noted here, that this proposed separation of funds would have involved a considerable alteration in the practice and theory of the Trade Unionism of that date. Large funds were regarded by many of the societies as the chief weapon to be used in support of collective bargaining; and the Friendly benefits were invariably unhesitatingly devoted to support the members who were engaged in trade disputes when such support was required.

Several members of the Commission dissented from their colleagues on important points, and Mr. Frederic Harrison and Mr. Thomas Hughes embodied their opinions in a Minority Report. This Report urged that the notorious outrages had been perpetrated by unimportant societies, and that such acts were not characteristic of Trade Unions as a whole. It was admitted that some of the Societies attempted to limit the number of apprentices, and to restrict the use of machinery, but it was argued that these practices had had no appreciable effect upon the volume of national trade and production. It was contended that the larger Unions, with their extensive Friendly Society organisations, had contributed to the stability of trade, and had also conferred great benefits not only on their own members but on the working classes generally. The Minority Commissioners opposed the suggested separation of funds, and argued that it was impossible to draw a sharp line of demarcation between trade and benefit purposes, and they also maintained that the existence of purely trade funds would tend to foster strikes. They therefore urged that the Trade Union funds should be brought under the ægis of the Friendly Societies Acts and so given the necessary protection. The Minority Commissioners also recommended that no act should be considered illegal if 
committed by a workman, which would not be equally illegal if performed by any other person, and that no act performed by a combination of men should be criminal which would not be criminal if committed by an individual.

The legislation which resulted from the inquiry was based rather on the recommendations of the Minority than on those of the Majority. Public opinion had begun to recognise the fact that the injustices under which the Unions had laboured had contributed to produce the sins against society of which the Sheffield outrages were the most notorious examples. The Times voiced the new recognition that the Trade Unions had a right to exist, declaring that: "True statesmanship will seek neither to augment nor to reduce their influence, but accepting it as a fact will give it a free scope for legitimate development." 1 The Trade Union Act of 1871, together with the amending Act of 1876 , swept away all the antiquated theories of restraint of trade. It was enacted that the purposes of any Trade Union should not be deemed unlawful, merely for the reason that they were in restraint of trade, and the members of such Unions were no longer liable to undergo criminal prosecution for conspiracy. The privilege of registration under specified conditions was also given to the Unions.

Two other measures which had an important bearing on workmen's combinations were passed in 1875 . The Conspiracy and Protection of Property Act set definite limits upon the application of the Law of Conspiracy to trade disputes, and defined the acts which constituted unlawful intimidation and annoyance. The Master and Servant Act was superseded by the Employers and Workmen Act, which placed the workmen in

${ }^{1}$ Leader in the Times. July 8th, 1869. 
a position of equality with their employers in matters of civil contract.

The legalisation of Trade Unions was thus completed. The old punishment of imprisonment for breach of contract, save in cases where the breaking of a contract would endanger human life, or cause serious bodily injury, or expose valuable property to danger or destruction, was abolished. Peaceful picketing was permitted, and it was enacted that violence and intimidation were to be dealt with in future under the criminal law. Employers and employed were entitled to perform all acts in combination which they might legally perform as individuals.

The full legalisation of collective bargaining afforded a new stimulus to Trade Unionism. From the year 1871, when the first step was gained, a short period opened during which working men's associations were imbued with extraordinary energy. The tide of enthusiasm again reached the agriculturists, whose Union had been suppressed in 1834 at the time of the conviction of the six Dorsetshire labourers. Henry Crompton has testified to the very real need of combined action on the part of the labourers, who were undeniably in a miserable condition of poverty: "The ignorance of the labourers upon the subject of contract is most conspicuously shown at the statute fairs and yearly hirings, where they sign yearly engagements of the vaguest and most unjust description, without being aware that they might easily have got fair terms if they had had anyone to advise them who had his wits about him. They are often without the very idea of bargaining or of getting favourable terms for themselves." 1 Joseph Arch, the founder of the field labourers'

1 Industrial Conciliation. H. Crompton. p. 137. 
Unions, encountered bitter hostility. Squires, clergy, doctors, and local farmers vigorously opposed all attempts at association. A strike, however, of some two hundred men for higher wages received sympathetic notice in the Press, and large funds were contributed to assist the men. The movement, which it is interesting to recall received the support of Cardinal Manning, once launched, spread with amazing rapidity. The National Agricultural Labourers' Union claimed a membership of nearly a hundred thousand within a few months of its foundation. ${ }^{1}$ That associative effort was justified is illustrated by the statement that in many villages the mere formation of a branch led to an instantaneous rise of wages. ${ }^{2}$

Attempts were also made during this period of activity to organise the unskilled labour at the docks. A Union was formed amongst the riverside workers, which succeeded in obtaining some temporary advance in wages, though it enjoyed but a brief existence. ${ }^{3}$

By 1874 a cycle of serious trade depression again checked the growth of the movement. Large numbers of men were thrown out of work in every trade. Reductions in wages and an increase in the hours of labour were of common occurrence. Many Unions disappeared, while those which remained in existence seemed quite unable to withstand the pressure which again persistently lowered the standard of life.

In some districts, such as South Wales, Trade Unionism practically died out; but the heart of the movement remained sound. Some of the large amalgamated societies, though their funds were depleted by the constant drain

1 History of Trade Unionism. p. 315.

2 Ibid., p. 317.

3 Trade Unions. Geoffrey Drage. p. 18. 
of out-of-work benefits, retained their membership, and several important new societies sprang into being.

During the years when growth had apparently ceased, the movement was not really at a standstill. The annual Congress, which had been first convened in 1868 , was continuing to meet. Such questions as piece-work, overtime, the protection of miners, conciliation and arbitration, were receiving increasing attention in the Trade Union world. While each individual Union was struggling to raise the wages and better the conditions of employment in its own particular trade, Labour legislation was arousing the growing interest of the whole movement. Parliamentary action had become a distinctive policy of the Unions, and Mr. Thomas Burt and Mr. Alexander Macdonald were returned to the House of Commons in 1874 as the first Labour representatives. It was indeed apparent, by the close of the first decade after the legalisation of the Unions, that the Spirit of Association had found expression in organisations which were destined to endure and to exercise a great influence upon the industrial history of the people of Great Britain. 


\section{CHAPTER XVI}

\section{THE AIMS AND FUNCTIONS OF TRADE UNIONS}

\section{FRIENDLY BENEFIT WORK}

IT will be well to describe some of the most characteristic aims and functions of Trade Unions before I attempt to outline the main events which have taken place in relation to the organisation of labour during the past twenty years. A cycle of industrial conflict has for the last two years somewhat obscured the more normal operations of Trade Unionism, and it is to these that we would draw attention in the present chapter.

Strife, intimidation and violence attain by their very nature to an easy notoriety, whereas quiet and persistent efforts to raise the standard of life by means of collective bargaining and mutual aid have a tendency to remain unobserved in the background. The consequence is that the faults in policy, and the fallacies in economic theory, which have been incidental to the development of Trade Unions, and which will receive consideration in a subsequent chapter, have received at times so large a share of attention that some of the achievements of these 


\section{AIMS AND FUNCTIONS OF TRADE UNIONS}

organisations have not always received their due share of recognition.

We have traced through the ages the stirring of an impulse which has induced men to unite with the object of sharing the burden which, pressing too heavily upon one individual, may be more easily borne if shared by a fraternity. This same impulse was one of the motive forces which produced Trade Unionism. The mutual aid which has been afforded by Trade societies has, however, had a deeper significance than the mere relief of an individual member in sickness, unemployment or distress. The relief system which the Unions have established has been based, to no small extent, upon the deliberate conviction that the judicious relief of a minority may serve as a lever to raise the standard of life of the majority. This has been the guiding principle of the great bulk of the Trade Union benefit work. The theory being that unrestricted competition holds the wageearner at its mercy, and that the accumulation of benefit funds tends to act as a check upon this competition. Such funds give the Unions a reserve force which, when trade flags and unemployment increases, enables workmen to be temporarily withdrawn from the labour-market as an alternative to competing amongst themselves and accepting less than the standard wage.

It is also argued that the strength provided by reserve funds may operate to prevent attempts being made by employers to cheapen production and to undercut one another by the expedient of lowering wages.

Before the suffrage was extended to working men, or the development of schemes of conciliation and arbitration, and while Unions were still illegal bodies, mutual insurance as a reinforcement to collective bargaining 
was emphatically the one means by which Trade Unions could hope to improve the conditions of employment for their members.

The principle upon which mutual aid has been afforded by the Trade Unions has, therefore, always been fundamentally different from that which has inspired Friendly Society assurance. The regulation of industry in the interests of the employees being the paramount aim of the Unions, the connection between Trade Unionism and insurance is cemented by the desire to secure the " moral influence," which a backing of large reserve funds gives, in conducting negotiations with employers. The Friendly benefit work has also sprung from the desire to attract members into the societies, and to promote discipline within the ranks. The effective powers of the Unions depend in a very special degree upon securing as members the majority of workers in any given trade. It will be readily understocd that the offer of tangible benefits in case of accident, sickness, superannuation, or burial is a powerful magnet whereby to induce men to join the Unions; and also secures the continuance of their membership when they have once joined. The disciplinary powers which these benefits afford are also considerable and may, indeed, be open to abuse. A man is unlikely to oppose the will of his society, when such opposition would reap expulsion and the loss of prospective out-ofwork and sick pay, for which he may have contributed for years.

The steadying effect of Friendly benefits on the policy of the Trade Unions is of course very great, and may be illustrated by the experience of a large Union, which was founded in the West of England in 1872 with the sole 


\section{AIMS AND FUNCTIONS OF TRADE UNIONS}

object of protecting Labour. "The Society," wrote the secretary, "was continued on that basis for some years, with varied success. As soon as we got means and members, the men struck, drew out all the funds, and we then had to start again." The subsequent introduction of Friendly benefits was found to have "the effect of greatly reducing strikes, and of introducing into Labour disputes a spirit of conciliation.... We had fewer strikes, good and solid progress was made in regard to the men's work and hours of labour-far more than they had ever made at any period by the most successful strikes that they had ever had." 1

Experience has, however, shown that Trade Unionism, with a high enough rate of contributions to develop Friendly benefit work, is beyond the reach of the unskilled, semi-employed, or inadequately paid grades of labour. The result has been that hitherto the majority of the societies formed in the unskilled trades have been both ephemeral in character and unstable in policy.

The benefit work of the Trade Unions may be conveniently divided into two distinct classes: first, the dispute and trade protection benefits; and secondly, the Friendly benefits.

The dispute benefit is given to members who are thrown out of work by trade disputes. It takes the form of a weekly allowance which endures either for a limited period, or until the strike is over, or until the member has found employment elsewhere. "Victimised" or "sacrificed" members who have been discharged on account of their connection with the Union also receive temporary support. ${ }^{2}$

1 Trade Unions. Geoffrey Drage. pp. 46, 47.

2 Ibid., pp. 36, 37. 
Friendly benefits are provided for such circumstances as sickness, burial, accident and superannuation. Some Unions also make allowances to their members when they are prevented from following their trade by the sanitary authorities, on account of infectious disease in their homes. The Friendly benefits also include " grants for replacing tools lost by theft or fire," and " out-of-work pay," from the old-fashioned " tramping card" to the modern "donation" given when a member loses his employment by the temporary breakdown of machinery or "want of pit room," by the bankruptcy of his employer or the stoppage of a mill, or merely in consequence of a depression in trade." 1

It has also been one of the principal aims of the Unions to help their members to find work. A member knowing of a vacancy is very generally bound by rule to inform his branch secretary of the fact. The societies have been in a particularly strong position to administer unemployed benefit, by reason of their knowledge of the circumstances of trade and of their individual members. They have been able to force their men to accept employment, when offered at a standard rate, rather than to remain on donation. ${ }^{2}$ There has been great variety of practice among the Unions of skilled artisans with respect to out-of-work benefit. It has been a prominent feature in the metal, engineering, printing, and bookbinding trades, whereas the textile workers and the coal-miners and many branches of builders make but little provision for unemployment. The Unions of unskilled workers have done practically nothing in this direction. Doubtless in trades where wages are low, and employment is inter-

1 Industrial Democracy. S. \& B. Webb. Vol. I, p. 153.

2 Report of the Poor Law Commission, 1909. Pp. 312, 313. 


\section{AIMS AND FUNCTIONS OF TRADE UNIONS}

mittent, the difficulty of inducing men to pay sufficiently high rates to insure them against unemployment, and of administering the insurance, has been almost insurmountable.

Unlike the member of a Friendly Society, a Trade Unionist has no real security with regard to the receipt of the benefits for which he has subscribed. The Union enters into no legally binding contract with its members. The consequence is that as the payment of out-of-work and dispute benefits is always considered to have an indefeasible claim upon the funds of the society, the member who may have contributed for years to the sick and superannuation funds has no guarantee that he will ever receive payments during times of illness or in old age. The Friendly benefits of the Trade Unions cannot therefore be compared for a moment with those of the Friendly Societies. The benefit work of the Unions is not based on actuarial science. The societies provide primarily for events, such as trade disputes and strikes, which are not calculable by scientific rules. The solvency of their condition can be neither ascertained nor guaranteed by the rules of an actuary, as the value of all calculations may be discounted at any moment in the event of the Union embarking upon a strike. ${ }^{1}$

The contingency which may deprive a member of sick-pay or superannuation may also cause him grave additional hardships. He may be required to pay extra levies, just when he is least able to do so, to meet heavy out-of-work liabilities, and is liable to expulsion if he fails to comply. ${ }^{2}$ This insecurity in the Friendly benefit work

1 Fortnightly Review. Frederic Harrison. 1869.

2 Industrial Democracy. S. \& B. Webb. Vol. I, p. 154. 
is a very definite evil in Trade Unionism, and it is probable that in this respect the Insurance Act will exercise a beneficial influence. The Unions which form approved societies, being obliged to reserve the funds received under the Act to meet the requisite sick and invalidity allowances, a complete division between Friendly benefits and dispute funds may result. There can be no doubt that a division of the funds would have certain advantages for the members. Their savings would be assured to them, and their freedom as individuals would be increased, for under present conditions the fear of losing the savings of a life-time does unquestionably place the members in a position of servitude to the executive. ${ }^{1}$

While the irregularity, with regard to the payment of benefits, which we have just considered, has seriously militated against the utility of the Trade Unions as insurance societies, there is no doubt that the out-ofwork benefit in all its ramifications has been of very great value to the members. The fact that a Trade Unionist rarely makes application to the Poor Law authorities is largely accounted for by the means which the Unions adopt to tide their members over periods of temporary unemployment. The "travelling benefit," which requires a member to journey from town to town, often by a prescribed route in search of work, is a means of enforcing discipline. The "shifting money," which helps a member, and sometimes his wife and children, to remove to a district where there is a demand for men of his trade, serves to promote the desirable mobility of labour. Finally the "emigration benefit," though it cannot be said to have been given on a large enough

1 Trade Unions. Geoffrey Drage. p. 58. 


\section{AIMS AND FUNCTIONS OF TRADE UNIONS}

scale to touch the problem of unemployment, is undoubtedly of service in helping individuals to find employment in other countries. ${ }^{1}$

\section{THE APPEAL TO PARLIAMENTARY ACTION}

We have already shown that the atrophy of the powers which regulated industry before the days of Queen Anne was among the causes which brought Trade Unionism into being, and that the operatives attributed the lowering of their standard of life during the eighteenth century to this cause. It is, therefore, not surprising to find that one of the great means by which Trade Unionists have sought to obtain their ends has been by invoking the action of Parliament. The code of Factory Acts which has been of incalculable value to the nation owes its development to some extent to the persistent efforts of Trade Unionists to secure the statutory regulations, which the inquiries of the Labour Commissions of the first half of last century had shown to be so urgently needed. The names of Robert Owen, the Earl of Shaftesbury, Michael Sadler, John Fielden and Richard Oastler will always be honourably connected with the early struggles to secure factory legislation, but year by year as the agitation grew it was largely supported by the operatives themselves. The efforts of Trade Unionists were at first merely directed to protecting the women and the children

1 There is a very general misconception as to the proportion of Trade Union Funds which is devoted to the support of members during disputes and strikes. The roo principal Unions were shown to have devoted, on the basis of an average of the ten years 1 897-1 906 , only 13.4 per cent. to disputes, whereas 22.1 per cent. was devoted to unemployed benefit, and 42.5 per cent. to Friendly Benefits other than unemployed. It is notable that these Unions spent almost as much on the valuable superannuation benefit alone as on disputes. 
from excessive hours of toil. How far these efforts were inspired by a desire to reserve sufficient employment for the men is difficult to determine. One of the first effects of the Factory system had indisputably been to drive the men from employment, and to create a demand for the cheap labour of women and little children. Whether humanitarian or interested motives predominated, it appears that by about 1830 a great number of working men were convinced of the wisdom of limiting the hours of labour of factory children. ${ }^{1}$ The petition which Sadler presented to the House of Commons in 1832, praying Parliament to adopt some means of limiting the children's hours of labour, received the support of some 10,000 operatives. During the same session petitions of a similar character flowed in from Huddersfield, Bradford and Glasgow. We are told that in order to show the direct need of legislation the men "exhibited the factory children in a great street procession just as they left work, stunted, distorted and pale as spectres, a sight amongst the saddest ever seen on this earth since labour became a duty of life." 2 From this time the Unions of textile workers gave

1 " Tuffnell, one of the Commissioners, who collected evidence for the Parliamentary Commission of 1833 , said that the fact which had struck him most in the course of his investigation was the different grounds on which the Ten Hours Bill was advocated in Parliament, and in the manufacturing districts. He described the cruelty of employing young children for long hours, and the cruel usage to which they were submitted, as the Parliamentary and public ground for supporting the Bill. But, he went on to say, not a single witness that came before me to give evidence in favour of the Ten Hours Bill . . . of whatever trade or station he may have been, supported it on the above grounds. . . . I am perfectly satisfied that motives of humanity have not the smallest weight in inducing them to uphold the Ten Hours Bill." History of Factory Legislation. B. L. Hutchins. A. Harrison. p. 50.

${ }_{2}$ Progress of the Working Class, i $832-67$. J. M. Ludlow and Lloyd Jones. p. 92. 


\section{AIMS AND FUNCTIONS OF TRADE UNIONS}

vigorous and effective support to the Ten Hours Bills, which were advocated by Robert Owen and Lord Shaftesbury. The miners were slower to realise the necessity for protective legislation, but the shocking disclosures of "the most sensational Blue Book of the century," as the Report of the Children's Commission was called, helped to promote the first Mines' Regulation Act, which placed restrictions upon the labour of women. From 1843 the miners began to be convinced that the true line of advance lay in the promotion of the statutory regulations of their industry, and from that time the Miners' Unions have exercised a great influence in furthering the regulation of mining and colliery labour. Alexander Macdonald, the celebrated Labour leader, who began his mining career in a pit at the age of eight, made an interesting statement with regard to his conversion to a belief in industrial legislation : "It was in 1856 that I crossed the Border first to advocate a better Mines' Act, true weighing, the education of the young, the restriction of the age to twelve years, the reduction of the working hours to eight in every twentyfour, the training of managers, the payment of wages weekly in the current coin of the realm, no truck, and many other useful things too numerous to mention here. Shortly after that, bone began to come to bone, and by 1858 we were in full action for better laws." 1

The enfranchisement of the town artisans in 1867 , and of the miners and the county operatives in 1885 , gave the working-men new powers in agitating for legislative action. From 1874, when the first two Labour representatives entered Parliament, the Trade Unions have persistently agitated for legislation which they have

1 Cited by S. \& B. Webb, History of Trade Unionism. p. 286. 
conceived to be favourable to Labour. The employment of an adequate staff of inspectors, the Employers Liability Act, the Metalliferous Mines Act, the Railway Regulations (Hours) Act, the Fair Wage Clause in Government and Municipal Work, and the Trade Disputes Act, have one and all received the vigorous support of the Labour representatives in the House of Commons.

The reliance on Parliamentary action has led to the organisation of a general political machinery throughout the Trade Union world, in the shape of Trades Councils, the Congress, and the Parliamentary Committee. ${ }^{1}$ The Trades Councils, which have been established in many large towns, afford the means for debating questions of policy. These councils are formed by the Trade Unions of the diverse industries in a locality, and do not as a rule take any share in the conduct of trade disputes. They often indeed endeavour to promote the settlement of differences by conciliation and other amicable means, and in many districts have joined with the Chambers of Commerce in the establishment of local boards of arbitration and conciliation. They also frequently petition Parliament, and attempt to induce local members to support or oppose particular legislative measures affecting labour. ${ }^{2}$ Whilst these Trades Councils have thus exercised some influence as representing the members of Unions employed in a variety of trades, the cotton operatives and the coal miners have constructed powerful organisations of their own for obtaining and enforcing legislative action in their respective industries. The Trade Union Congress has, since I868, watched year by year over all legislative matters affecting directly or

1 Industrial Democracy. S. \& B. Webb. Vol. I, p. 252.

2 Trade Unions. Geoffrey Drage. pp. 105-I09. 


\section{AIMS AND FUNCTIONS OF TRADE UNIONS}

indirectly the Trade Unionists of the country. Each year a host of fresh demands pours in to the Congress from divers Unions, demanding an extension or alteration in the Factory Acts. At each annual Congress a Parliamentary Committee of eleven members is appointed, with the threefold instruction to watch all legislative measures directly affecting the question of Labour, to initiate such legislation as Congress may direct, and to prepare the programme for the ensuing Congress.

How great a driving force the Trade Unions have actually proved in the past in initiating and securing statutory regulations is not easily determined. The small Unions have probably accomplished but little with regard to the individual interests of their several trades. The miners and cotton operatives, however, who dwell in such numbers in some of the constituencies in the north of England that they are able to return Members to the House of Commons pledged to act on their behalf, have been remarkably successful in securing legislative regulation.

The history of the coal strike which took place in the early months of 1912, and the part which Parliament played in the dispute, afford a notable illustration of the political power which now rests with the miners. With regard to all political questions which touch the Trade Union world as a whole, the influence which the Unions have exercised is undoubted. When some Labour question is to the fore, and the vote of the vast majority of Trade Unionists has consequently to be reckoned with, it is hardly necessary to emphasise what an enormous influence such a mass vote must have at a General Election. I shall have occasion to show that in my view both justice and considerations of public welfare 
demand the enactment of legislation which is unlikely to prove acceptable to all Trade Unionists. Courage will be required to run the risk of alienating a considerable body of the electorate, and to tackle firmly one of the thorniest questions of the present day, with regard to national rather than sectional interests.

\section{COLLECTIVE BARGAINING}

Collective bargaining, by means of which the workmen employ their own representatives to conduct negotiations for them en bloc with employers, has superseded the old individual contract between master and servant in a great part of the industrial field. ${ }^{1}$ The custom of employing Trade Union officials in the work of conducting trade negotiations has considerably increased in recent years.

In the days when Mr. Frederic Harrison first fought the battle on behalf of Trade Unionism, he found that these officials were almost invariably simple members of the societies, whose salaries rarely exceeded their ordinary wages. The situation has in this respect greatly changed. The growing complexity in the processes of manufacture in some trades has led to the employment of skilled and trained officials to act on behalf of the Unions in the place of working men. The change in the type of official who represents the operatives, for instance, in the cotton industry, has been an absolutely necessary development. The ascertainment of facts when a difference arises with regard to the payment which is due to an operative under some elaborate price-list requires a scientific accuracy and technical knowledge which a special training alone can give. The interpretation of

${ }^{1}$ See, for a full account of Collective Bargaining, Industrial Democracy. S. \& B. Webb. Vol. I, ch. ii. 


\section{AIMS AND FUNCTIONS OF TRADE UNIONS}

price-lists may therefore be quite beyond the mental scope of the ordinary spinner or weaver. In the yet more delicate task of forming new agreements the negotiator requires an intimate knowledge of the circumstances of the trade, patience, tact, prescience, a power to command the confidence of both employers and employed, and a whole combination of qualifications with which the mill or factory " hand" is not endowed. The complicated duties which rest with the salaried officials of the cotton spinners and cotton weavers has led to the custom of selecting the officials by competitive examination. The success of Trade Unionism in the cotton industries may doubtless be largely ascribed to the fact that the work of negotiation has been placed in the hands of really competent men. In the Lancashire cotton trade both masters and men are extraordinarily well organised, with the result that an exceptional recognition of the mutual interests of Capital and Labour is said to exist. The fact that higher wages are earned by the cotton operatives in Lancashire than by those engaged in the same industry in any other part of Europe, and that at the same time the trade maintains its predominant position in the markets of the world, constitutes a strong argument in favour of efficiently conducted collective bargaining.

The type of officials who are engaged by the different Unions throughout the country varies enormously with the circumstances of the industry. There are the general secretaries who devote constant attention to the financial stability of their Unions. There are the highly trained and capable officials whose work we have described, whose intimate knowledge of industrial conditions is said to have given effective help in the shaping of the Factory 
Acts. There are the shrewd, far-seeing, resolute, but self-controlled men, who, as Professor Marshall has declared, exercise such a strong, pacific influence on the executives of the best organised Unions. On the other hand, there are to be found among the "Labour organisers" excitable, ill-balanced stormy petrels, whose one aim appears to be to stir up industrial strife, and then to seize the opportunity, when imagination and passions are heated, to proclaim the infamous doctrines of a class war.

The Unions of unskilled workers, such as dock-labourers, owing to the insufficiency of their funds, are often unable to secure the services of an efficient staff of officials. Such societies, therefore, exhibit a tendency to fall into the hands of professional agitators, and are liable to rush into ill-considered declarations of war.

In the present chapter, however, we are merely dealing with the normal expressions of Trade Unions, and it is hardly realised, in a period when strikes, conducted on an unprecedented scale, have attracted much attention to Trade Unions, how many efforts are made in the ordinary course of events in a trade dispute towards securing a peaceful settlement before a strike is actually embarked upon. The aggrieved members are instructed by their Unions to present their case to the officers or secretary of their branch. These officials then attempt to effect an amicable settlement. If their efforts fail, a meeting of the branch is called, and if the matter is thought to be of sufficient importance, the whole circumstances are laid before the general secretary of the Trade Union, who submits the information to the Central Executive. This body then attempts to find a solution to the difficulty which will prove acceptable to both parties. 


\section{AIMS AND FUNCTIONS OF TRADE UNIONS}

Only when this effort has failed has the question of the advisability of declaring a strike to be decided. Even at this stage of the proceedings some Unions require that the vote of all the members shall be taken by means of ballot-papers. This course has the advantage of arousing the loyalty of the men and securing the necessary support for the leaders in the event of a struggle. If the suffering which results from a stoppage of work has to be faced, it is well that the men should be convinced of the wisdom of resorting to extreme measures. ${ }^{1}$ The disadvantage, however, of appealing to the rank and file is that men who are inflamed by a sense of personal grievance may vote for declaring war against the better judgment of their appointed leaders. The history of the industrial struggles of the last two years has certainly shown that the men on several occasions have declared for war, or its continuance, against the advice of their responsible officials.

In addition to ensuring deliberate consideration for disputed points, many of the Unions attempt to regulate the attitude of their members towards employers and foremen. They forbid the men to boast of independence on account of their connection with a Trade Union. Many rules also forbid any breach of contract or dishonesty towards the employers. The Boilermakers and Iron and Steel Shipbuilders' Union even undertakes to compensate employers for any loss occurring to them in consequence of bad workmanship, or breach of faith upon the part of their members, and recovers the necessary sums by means of fines imposed upon the members who are at fault. ${ }^{2}$ There would be but one view of Trade

1 Trade Unions. G. Drage. pp. 59-63.

2 Ibid., p. 65. 
Unionism and collective bargaining were such moderation and discipline to become general.

\section{ARBITRATION AND CONCILIATION}

In some cases it must also be noticed that the rules of the societies require that before all hope of settlement is abandoned, an offer shall be made to the employers to submit the difficulty to arbitration and conciliation, and certain of the Unions even require that in the event of the offer being rejected the first time it shall be repeated. Some societies also appoint representatives to serve with the employers on permanent Boards of Conciliaton, which are established as a means of preventing and removing causes of dispute.

If the disputants agree in advance to abide by the award of a third party or umpire, the mode of settlement is described as " arbitration." The term "conciliation" is used to cover a large number of methods of arriving at a settlement. These methods include discussions which take place before a mediator, when the parties are not bound to accept an award, and also the direct negotiations which are conducted between employers and workmen, either by means of a permanent board, or by a special meeting called to deal with any specific difficulty.

Conciliation has sprung from arbitration, and arbitration arose in France at the beginning of the nineteenth century as a result of the French Revolution. A people who imagined that the abolition of monarchy and the decapitation of a number of aristocrats had given them "Liberty, Equality and Fraternity," were in no mood to make the wheels of industry run smoothly. Disputes occurred with such frequency that certain legal tribunals 


\section{AIMS AND FUNCTIONS OF 'TRADE UNIONS}

were created which were named the conseils des prud'bommes. These councils were composed of both employers and employed, and had the power to summarily determine the disputes which arose in relation to contracts. The tribunals, however, had no power to fix the rate of wages for future agreements.

The same custom was adopted in England during the nineteenth century, and by about 1850 arbitration was regarded as pre-eminently the best means by which to allay industrial strife. Further experience proved that arbitration was too cumbrous a machine for the adjustment of insignificant disputes, and consequently it became customary to appoint smaller bodies of employers and employed to deal with small differences as they arose. This method of adjustment, which had been regarded at first as merely subsidiary to arbitration, gradually. assumed greater importance, and became the really essential and vital part of the system. ${ }^{1}$ Voluntary Trade Boards representing both employers and workmen in a particular trade have in fact become the most important agencies in Great Britain for the prevention and settlement of trade disputes.

The Rt. Hon. A. J. Mundella was the inventor of systematic industrial conciliation, and started the first permanent Board in his own hosiery trade in 1860 . The expedient which was then adopted at Nottingham was practically the institution of permanent machinery for collective bargaining. Three strikes had taken place in the hosiery industry in the course of a year, one of which lasted eleven weeks. The masters met to consider what steps should be taken. A general lock-out was proposed, which would have involved turning a large population

1 Industrial Conciliation. Henry Crompton. p. 22. 
into the streets. Wiser counsels prevailed, and it was decided to call a conference between masters and men. The masters explained, in happy phraseology, that the prevailing system was "mutually predatory," and as a result of the negotiations a Board of Arbitration and Conciliation was appointed. It is interesting to find that this Board was instrumental in settling the vexed question of frame-rents which had been a standing grievance among the stockingers for over a century. The Board existed for twenty years and worked admirably in preserving peace.

A similar Board was established in 1869 in the manufactured iron trade, in which endless disputes had previously taken place, causing wide-spread dislocation of industry. The Board reported some years after it was first instituted that during the whole period of its existence the question of wages and regulations had been settled without resorting to strikes or lock-outs. It was also stated that with few exceptions the operatives had been loyal to the rules laid down by the Board.

Meanwhile arbitration has continued to play an important though limited part in the settlement of industrial disputes. It has proved especially useful when the difference of opinion has merely related to a question of the interpretation of existing contracts, and where a basis of agreement has existed between masters and workmen as to the principles which should rule wages. In the North of England iron trade, for instance, both iron-masters and operatives have accepted the principle that wages should be regulated by the selling price of iron. Whether this be regarded as a wise assumption or no, it has meant that arbitration has been confined to the 


\section{AIMS AND FUNCTIONS OF TRADE UNIONS}

comparatively simple task of interpreting contracts after the ascertainment of absolute facts.

Arbitration cannot, it must be confessed, be said to have fulfilled the high expectations which its first introduction aroused, and experience has proved it to be open to certain objections. It has been urged that unrestricted arbitration has a tendency to increase the number of disputes by providing an easy way of settling them without involving a trade in strikes or lock-outs. It is therefore said to diminish the sense of responsibility in preferring claims. It is contended that arbitrators show a tendency to "split the difference" in the hope of satisfying both sides, and justice may thus be sacrificed. Arbitration is prone to lead to the formulation of high demands which admit of being cut down by the arbitrator. It has also been found that both masters and men are unwilling to submit certain classes of disputes to the judgment of a third party. Questions such as the right of the employer to engage non-union men, the restriction of piece-work, the limitation of apprentices, and all matters concerning the maintenance of discipline, have not as a rule proved amenable to arbitration. The workmen in some trades have shown themselves unwilling to run the risk of having their wages reduced below a certain point which they have regarded as an essential minimum. Umpires have also shown a tendency to look upon such questions as the equitable rates of wages as outside the possible jurisdiction of an arbitrator.

When Lord James, Lord Rosebery and Sir Courteney Boyle undertook the task of arbitration in cases where there had been a serious industrial dead-lock, they did not attempt to issue a judicial decree. They merely persuaded the contending parties to continue the nego- 
tiations under the eye of an impartial umpire until the disputants themselves had found a means of settling the dispute. ${ }^{1}$ Arbitration on occasions such as these has been arbitration in name rather than in fact, and mediation has won the day. Before the Conciliation Act of 1896, Parliament had made a few attempts to promote arbitration and conciliation, but these efforts had been practically ineffective. The evidence given before the Royal Commission on Labour (I89I-I 894) revealed that a strong body of opinion existed which favoured further action being taken by the State for the prevention and settlement of trade disputes. The successful intervention of the Board of Trade, which was undertaken without any special legislative sanction, in the coal miners' dispute of I 893 and the cab-drivers' dispute of I894, when Lord Rosebery and Mr. Asquith respectively acted as mediators, also served to deepen the conviction that Parliamentary action was called for. The Act of 1896 , which resulted, is of a purely voluntary character. Its most important provisions are those empowering the Board of Trade to inquire into any dispute arising, or even threatening to arise, between employers and employed, or between different classes of workmen. The Board is also authorised to promote a conference between the contending parties and to appoint a conciliator on the application of either side, or an arbitrator at the request of both parties. It is indicative of the hesitation which has been manifested to invoke outside intervention in trade disputes that of 3,868 labour disputes, which took place during the first five years after the Act came into operation, only I I 3 were dealt with under the Act. During the last ten years, however, the Board of Trade has intervened

1 Industrial Democracy. S. \& B. Webb. Vol. I, p. 24 r. 


\section{AIMS AND FUNCTIONS OF TRADE UNIONS}

in every dispute of any considerable importance, and its action has done much to induce disputants to arrive at a settlement.

In I9II, in order to supplement and strengthen the operations of the Board of Trade in the discharge of its duties under the Conciliation Act of $\mathbf{1 8 9 6}$, an Industrial Council was established. This Council is composed of representatives of both employers and workmen, and under the chairmanship of Sir George Askwith is empowered to inquire into all matters referred to it affecting trade disputes. The Council has no compulsory powers, but is authorised to undertake the work of investigation, conciliation or arbitration as the case may be, and to foster such voluntary methods or agreements as are in force at the present time for the prevention of strikes or lock-outs or the settlement of disputes. Meanwhile voluntary Trade Boards, on which both employers and employed are represented, have been making steady progress. In the mining and railway industries and in the building trade at the present time there are comprehensive systems of Conciliation Boards. The work which they perform may be illustrated by the fact that nineteen Boards in the coal trade considered 4,682 cases between the years 1900 and 1909 inclusive, and stoppages occurred in only fifty-one of these cases. ${ }^{1}$ It is maintained of the building trade at the present time that the men show a disposition to prefer the intervention of the Conciliation Board before resorting to a withdrawal of their labour. ${ }^{2}$ To what extent the amended scheme of Conciliation Boards which came into operation on July Ist, I9I2, will serve to allay unrest in the railway world
1 Industrial Warfare.
C. Watney and J. A. Little. p. 129.
2 Ibid., p. 196. 
cannot yet be predicted. There appears, however, some reason to hope that machinery has now been devised by means of which any grievances of the men will receive full consideration, and this fact should tend to allay discontent and mistrust.

The history of past experience certainly points to the conclusion that in the organised industries of the modern world the sphere of usefulness of arbitration has definite limitations. When the services of an umpire are invoked his success mainly depends on his power to induce the disputants to find their own basis of agreement. There appears, on the other hand, every reason to hope that as the organisation of industry makes irresistible progress, volun tary Conciliation Boards may play an evergrowing part in preventing industrial disputes. Such methods tend to humanise the relations between the management and the workers, and to drive home the realisation, without which no industry can attain its highest possible degree of efficiency, that the interests of Capital and Labour, employer and employed, are closely interlocked.

\section{RESTRICTION OF NUMBERS}

In the vast majority of British industries the apprenticeship system is either dying or dead. The increased use of machinery, and the consequent sub-division of labour, has rendered a term of indentured service in numerous industries unnecessary. Not only has the custom disappeared from many trades in which it formerly held its sway, but the greater number of Trade Unionists now belong to occupations in which it has never existed, and to which indeed apprenticeship is perhaps unsuitable. 


\section{AIMS AND FUNCTIONS OF TRADE UNIONS}

To bewail the decline of apprenticeship is fruitless. The inexorable changes in modern industrial processes have occasioned new demands on skill and character which must be met by new methods. Transitions of workmen from trade to trade are persistently taking place. Some industries demand the services of a large number of boys, who are destined to be discharged when they reach manhood, others have a surplus of men in the prime of life, and finally there are decaying industries in which the proportion of older men, who are past their full strength, is excessive. ${ }^{1}$ Conditions such as these demand pliability on the part of the individual rather than the devotion of years to the acquirement of a particular form of skill, for which the occasion may have disappeared by the time the technique is mastered. Even in the engineering trade the demand is now for "allround" mechanical engineers, men who can apply the principles of their craft to any form of machinery that may be called for, and it is maintained that the class of training which is required to produce artisans of this type cannot be acquired by any system of apprenticeship. ${ }^{2}$

It appears, therefore, that irresistible forces will ultimately give the apprenticeship system its quietus, but meanwhile in certain trades in which craft-knowledge of the older type is yet required, apprenticeship yet lingers on. It is maintained, with regard to some of these industries, that the regulations made by the Unions are both damaging to trade, and detrimental to the prospects of the rising generation. The employers, for instance, in the Yorkshire glass bottle trade are said to have recently

1 For an account of this flow of labour from trade to trade, see Life and Labour in London. Charles Booth. Part I, ch. v.

2 Evidence of Sir Christopher Furness. Report of the Poor Law Commission, 1909, p. 331. 
complained that under the operation of Trade Union law, understood rather than written, it was practically impossible for apprentices to learn the trade. ${ }^{1}$ It appears also that in the flint glass industry arbitrary powers are exercised by the Union officials in order to restrict the number of apprentices. In some branches of the Sheffield cutlery trade, there are stringent regulations for limiting apprenticeship to the sons of men already engaged in the trade, or to a very small number of newcomers. This point may be illustrated by a rule of the Britannia Metal Smiths' Provident Society which is strongly reminiscent of the Gild regulations :

"No master shall have more than one apprentice at one time; if two or more partners they can have one each; and for limited companies the first ten men or fractional part thereof, one boy; from eleven to twentyfive men, two boys; and so raising one boy to every fifteen additional men."

The employers in this industry are said to be seriously hampered by an insufficiency of skilled labour. ${ }^{2}$ Hard and selfish rules such as the foregoing obviously restrict trade. It is alleged indeed that in some industries the regulations, instead of providing for expansion, serve to actually diminish the number of efficient workmen. This apprenticeship question is of crucial importance at the present time in the shipbuilding trades. The Employers' Federation is anxious to obtain more useful "learners." The Unions concerned do not appear to be willing to make concessions, and matters may well reach a crisis unless the men develop a far-sighted policy. ${ }^{3}$

1 Trade Unionism and British Industry. E. A. Pratt. p. 85.

2 Ibid., 132. 160.

3 Industrial Warfare. Charles Watney and J. A. Little. pp. 159, 


\section{AIMS AND FUNCTIONS OF TRADE UNIONS}

The attempts of the Trade Unions to limit the use of boy labour, as distinguished from apprenticeship, brings us to the fringe of a problem of extreme complexity and difficulty. The increased sub-division of industrial processes has made it possible for quite untrained lads to perform many simple and mechanical tasks. This has undeniably led in many instances to the substitution of boy labour for that of adult workmen. This tendency has been warmly contested by the Trade Unions, the societies having frequently based their objection on the fact that the boys so engaged obtain no proper technical knowledge of a trade. Almost every boy who enters certain factories and workshops knows that his future employment will lie elsewhere. Such boys are engaged and dismissed at random, and are usually discharged at about eighteen years of age, to find their way into some other occupation, or to face a spell of disheartening unemployment. The strain on courage and character may be great, and the core of the problem appears to be to so help and train each individual boy that he may learn to become master of his fate. The steady boy who shows diligence, and such aptitude as even unskilled labour demands, may possibly work for a growing wage in the service of the same firm until he becomes grey-headed, but such opportunities are rare, and change of occupation more probably lies before him, and then- " the readiness is all."

A higher level of general education, technical training directed to instilling a measure of manual dexterity and general skill, increased pliability to meet the economic and industrial changes, and a growth in stability of character to meet the irregularity and the rapid changes in modes of employment which the mill of modern life 
forces upon the workers, these appear to be some of the means by which the disasters connected with the transsitional years from boyhood to manhood may be averted.

The Unions are clearly unable to exercise any appreciable influence in this all-important matter by merely restricting the use of boy labour in factories and workshops, and their action may serve to drive the boys in to some forms of employment which are even less likely to equip them with efficiency and reliability in character. The tendency of the ubiquitous modern boy to engage in work which secures him relatively high remuneration, and some consequent independence, or a life of incident and adventure as a van-boy, "beer-boy" or newsboy, rather than to enter employment which offers him smaller pay, coupled with a training which will make him an efficient and reliable workman, requires to be dealt with by other agencies than Trade Unionism. The boy with exceptional foresight and determination usually wins his way through, but the obstacles in the career of the average boy under present conditions are hard to surmount. The consequence is that there is a wastage in ability amongst the boys who are poured from school into the labour-market, which strikes at the growth and even the maintenance of our national efficiency. The social reformer has here a task lying ready to his hand!

To return, however, to our examination of Trade Union policy, it appears to me on all counts that the Unions which enforce rules to unduly limit the number of apprentices or to restrict boy labour would do well to modify their actions. Restrictions undeniably limit production. By restraining competition among the workers they tend to lower efficiency, and this policy, if carried to excess, certainly serves to check the growth of industry 


\section{I4 AIMS AND FUNCTIONS OF TRADE UNIONS}

and the potential dividend of the country. There is reason to question whether the artificial restriction of the supply of workmen operates continuously in favour of the Trade Unionists themselves. It may serve to raise wages for a time, but it calls into play other forces which must be reckoned with. Wages which are artificially raised act as a stimulus to the employer to introduce labour-saving devices in order to reduce the number of employees; and though the community may thereby profit, the members of the individual Union stand to lose. If the restrictive policy be carried to extremes it may even raise the cost of production sufficiently to check demand, or to give an opportunity to foreign competitors to lure the trade from the country, and the employment may thus be lost to Great Britain. In these days of increased mobility of labour, the restrictions which were thought to be necessary two centuries ago are no longer required. It has been effectually demonstrated by the Lancashire cotton operatives and Northumberland miners that it is possible to secure relatively good wages and short hours, in addition to a high level of sanitation and safety, without any attempts being made to interfere with the employer's free choice of men. ${ }^{1}$

\section{REGULATIONS WITH REGARD TO NON-UNIONISTS}

The ostracism of non-union men appears to be as old as Trade Unionism itself; and the excesses which have been committed against blackleg labour and to coerce men into joining the Unions, have served, perhaps more than any other cause, to bring organised labour periodically into disrepute. Even Unions which have exercised

1 Industrial Democracy. S. \& B. Webb. Vol. II, p. 714. 
moderation in all trade matters have rigidly maintained a custom of excluding non-society men from employment, wherever it has been possible. This attitude has resulted from an absolute belief in the advantages which combined action in negotiation with employers may obtain; coupled with the recognition that the influence of the Union must largely depend on its having drawn the great bulk of the men engaged in an industry within its net. From the days when vitriol was thrown in the face of non-unionists, and even murder was perpetrated, pressure of one kind or another has been exercised to induce men to join the Unions, and this pressure has been indeed one of the normal functions of Trade Unionism. The words of William Crawford, a trusted leader of the Durham Miners, illustrates the attitude of mind which existed a few years before the Unions were legalised. On the question of associating with non-unionists he wrote: "It is no use playing at shuttle-cock in this important portion of our social life. Either mingle with these men in the shaft, as you do in every other place, or let them be ostracised at all times and in every place. Regard them as unfit companions for yourselves and your sons, and unfit husbands for your daughters. Let them be branded as it were with the curse of Cain, as unfit to mingle in ordinary, honest, and respectable society. Until you make up your minds to thus completely ostracise these goats of mankind, cease to complain as to any results that may arise from their action." 1 In some of the most highly organised industries it is said that the compulsion is so complete as to cease to be apparent : "No man not belonging to the union ever thinks of applying for a situation, or would have any chance of

1 Cited in History of Trade Unionism. S. \& B. Webb. p. 280. 


\section{AIMS AND FUNCTIONS OF TRADE UNIONS}

obtaining one. It is, in fact, as impossible for a nonunionist plater or rivetter to get work in a Tyneside shipyard as it is for him to take a house in Newcastle without paying the rates. This silent and unseen, but absolutely complete compulsion, is the ideal of every Trade Union." 1

The actual rules of a large number of societies provide for this "silent and unseen compulsion," by imposing definite restrictions upon the intercourse of their members with non-unionists. These regulations forbid the members to find employment for non-unionists, to teach or to help them in their work, and in some cases to work in the same establishment with them. The regulations of this type do not theoretically involve interference with the liberty of action of any persons except the members of the Unions. It need hardly be pointed out, however, that in practice these rules do generally operate to the disadvantage of the non-union men. For instance, if the majority of employees in an industry belong to a Union and refuse to work with non-society men, the master is often driven to discharge the few men who are unacceptable to their fellows, as an alternative to having his whole business disorganised by the withdrawal of the members of the Union.

There are other and more questionable rules which are intended to force all those within the trade into the Unions, and others which are directly aimed at prohibiting the employment of non-unionists. The extremists in the Trade Union world go so far as to deny the right of the non-unionists to work in organised industries at all. ${ }^{2}$ It is argued that the moral obligation to join the Union is

1 Industrial Democracy. S. \& B. Webb. Vol. I, p. 215.

2 Trade Unions. Geoffrey Drage. pp. 65-72. 


\section{THE POLICY OF COMPULSION}

absolute, and even comparable with the duty of citizenship. Whilst acts of intimidation and violence towards non-unionists and employers are deprecated by the leaders in the large majority of the societies, there has certainly been a recrudescence of the policy of compulsion among some Unions during the past few years. This policy has been manifested in the silent pressure which expels the "free worker" from the factory and the shop, and in deliberate and organised intimidation when he has offered himself for employment, during the recent outbreaks of industrial warfare. 


\section{CHAPTER XVII}

\section{NEW UNIONISM AND AFTER}

INTERNECINE warfare had been waged for some years within the Trade Union movement before the New Unionism of the eighties was rewarded by a signal victory in the success of the Dock Strike of I889. The conservative, mutual-insurance Unions had been hotly attacked by the Socialists, for being unduly cautious, for lacking a definite trade policy, and for taking too anxious care of their cash-balances to run any risks of their depletion by making adequate efforts in trade matters on behalf of the members. The habit of exacting the large contributions necessary to give Friendly benefits was also criticised on the ground that it precluded the lower grades of workers from forming Unions. It was alleged that such rules were perpetuating rather than alleviating the miseries of the industrial world. The Unionists retorted that the unpractical methods advocated by the Socialists promised no real help to the cause of Labour.

There was truth in the allegations which were made on either side. Ranting against wage-service, a quite unpractical programme, and promises of a speedy millennium as the consequence of its adoption, neither raised 
wages nor shortened hours. The Unions, on the other hand, which were formed of the aristocracy of Labour, had not only failed to reach the residuum, but had, it was alleged, tended to divide trade from trade, members from non-members, and to accentuate the gulf between the skilled and well-paid artisan, and the vast mass of unskilled labour. ${ }^{1}$ Neither by means of Trade Unionism nor Socialism had any permanent improvement been effected in the lot of the sweated worker.

The New Unionism of the "eighties" sprang from the ultimate blending of these apparently irreconcilable elements. Socialism contributed an enthusiasm for social amelioration which refused to accept the insupportable pressure upon the under-world of Labour as a necessary factor in the industrial order. Trade Unionism contributed practical experience, method, organising power and discipline.

The result of this reciprocal influence was that the New Unionism of 1889 differed widely in character from the impulse of revolutionary folly which swept over the trade societies in 1834 . The political and social outlook had entirely altered since Owen urged that it was necessary to annihilate the existing industrial system. Public opinion no longer regarded associations of working-men as bodies to be sternly repressed, but fully recognised the right of Labour to combine. The law had likewise admitted the claim. Poverty was also attracting the sympathetic attention of the middle and the upper classes in a new manner. A wave of social endeavour was breaking down the old acquiescence and indifference. Privately conducted investigations, the House of Lords Committee upon Sweating, the Industrial Conference of

1 Industrial Remuneration Conference. Report, p. 437. 
1885, and the Royal Commission on the Housing of the Poor, all served to produce a dawning realisation that casual employment and the degradation of life resulting from miserably inadequate pay constituted evils for which every class in the community had a responsibility.

The widened suffrage which the Reform Act of the previous twenty years had given to the labouring classes had inspired the workers with a faith in their own power to mould legislation. To this was added an extravagant estimate of the possible scope, and remedial influence of Parliamentary action. In this exaggerated belief in the omnipotence of the State we find one of the secrets of the disappointment which New Unionism subsequently reaped. It was insufficiently recognised that industry required to be infused with a new spirit, and that heightened aims, leavening the industrial world from within, were capable of accomplishing yet more than statutory regulations.

Meanwhile, representatives of working-men voiced the claims of Labour in the House of Commons, and it was confidently felt that step by step their demands would be conceded. The working-classes recognised that they were no longer without weapons, which they might use in a perfectly constitutional manner, for purposes of defence and attack.

The result of this expectancy and this confidence was that hope never beat higher within the movement : the Trade Unions stood upon the threshold at the door of opportunity. The extravagant Socialism which sought to nationalise private property, rout the competitive system and drive the Juggernaut Car of Capital from the field of industry, gave place to New Unionism with more moderate aims. 
The two outstanding characteristics of the wave of thought and impulse which swept over the Trade Union world were a belief in Parliamentary and Municipal action, and the recognition of the solidarity of Labour.

It was urged that social conditions might be gradually improved through the administration of the vestries and the town councils. It was hoped that much might be accomplished by working-men taking a share in Local Government. Municipal effort was to supplement Parliamentary action at all points. A recognition of the right of working-men to bear a share in the responsibility of Local Government was shown by Sir George Trevelyan, who appointed four Trade Unionists in 1885 to the magisterial Bench.

New Unionism contended that by means of the exercise of the recently acquired political power by the working-class electorate, a gradual remoulding of the municipality and the State, in the interests of the wage-earners, was possible. The disillusionment with regard to this part of the programme was without doubt one of the causes which prepared the ground for the Syndicalist. The New Unionism of the "eighties" also represented an awakening consciousness of the essential unity of organised Labour-the recognition of the brotherhood of the skilled mechanic and the navvy. The Unions began again to draw within their ranks the sections of industrial workers who had hitherto proved incapable of sustaining permanent organisations. The higher grades of workmen assisted the unskilled labourers to form Unions, and admitted them to their own societies in a manner that had been previously unknown. The whole constitution of the Amalgamated Society of Engineers was revised in 1892 , with the object of opening the ranks 
of the Union to practically all the mechanics in the various branches of the engineering trade. The plumber, the carpenter, the shipwright and engineer vied with one another in helping to form Unions amongst the labourers who worked with or under them. ${ }^{1}$ A tide of enthusiasm similar to that which had reached the lower grades of Labour in 1834 and 1872 thus again drew thousands of men, from the unskilled trades, into the ranks of Trade Unions.

A great impulse was given to the new movement by the venture of faith of 1889 , when ten thousand ill-paid, unorganised dock-workers struck work in response to the summons of Ben Tillett, who called to his aid Tom Mann and John Burns. Mr. Frederic Harrison has told the tale of John Burns' able generalship, and the self-sacrifice and the discipline which gained the victory. ${ }^{2}$ Five thousand pickets were maintained by night and day, without any outrage of serious consequence being proved, or the intervention of the police being required. John Burns raised the whole episode to the level of a crusade, emphasising again and again the plea of social duty. $\mathrm{He}$ preached the necessity for order, consideration for the sufferings of the women and the children, until the movement became, as he himself declared, more like the spread of a religion than a demand for higher wages.

Sympathy was aroused in all classes of the community, 648,736 were contributed to support the strikers. The skilled trades stood by the unskilled workers, until finally, after a four weeks' struggle, and owing to the pressure of public opinion, the influence of the Press, shareholders, shipowners, and merchants, and the mediation of $\mathrm{Mr}$.

1 History of Trade Unionism. S. \& B. Webb. p. 407.

2 National and Social Problems. F. Harrison. Part II, ch. v. 


\section{THE DOCKERS' VICTORY}

Sydney Buxton, M.P., Cardinal Manning, and the Bishop of London, practically the whole of the dockers' demands were conceded. The men won their sixpence an hour, and the right to a minimum engagement of four hours, which constituted an important departure as an initial attempt towards regularising dock labour. The victory, Lord Rosebery enthusiastically declared, "marked an epoch not merely in the history of Labour, but of England-nay, even of humanity."

High expectations were aroused, and it was again felt, as in 1834 and 1872 , that Trade Unionism had a great message for the unskilled labourer, and that organisation, legitimately used, might prove of incalculable service to him. The success of the strike had demonstrated that an appeal to the sense of justice of the general public was capable of enlisting an effective force on the side of the wage-earners.

As a result of the successful issue to the strike, tens of thousands of unskilled men rapidly formed themselves into societies of the purely militant Trade Union type. It was impossible for such Unions to exact sufficiently high subscriptions from their members to develop Friendly benefit funds, and an element which produced stability and served to check intemperate action was necessarily absent. The hopes which had been raised of creating permanent organisations for the vast numbers of the unskilled workers were again destined to be disappointed. The impermanence which characterised many of the trade societies which were formed after 1834 and 1872 again manifested itself, and a large proportion of the "New Unions" remained in existence but a few years.

Shortly after the initiation of the new movement, it appears that the prejudice against the accumulation of 
funds, and the organisation of Friendly benefit work, largely disappeared, and at the present day the outcome of the high hopes of New Unionism is that the strongly organised trades have become stronger, while the weaker have lost ground. Whereas the coal-miners, the textile workers, and those employed in the shipbuilding and allied industries have strengthened their organisations, Trade Unionism has declined amongst the agricultural labourers, the seamen and fishermen, the workers in the clothing trades, and throughout the general mass of unskilled and unspecialised labour. ${ }^{1}$

As regards the growth of Trade Unionism as a whole, there has been a very considerable advance during the last twenty years. This growth has been marked, however, as during the whole history of the movement, by oscillations in membership, which have corresponded with the fluctuations in trade. In 1892, a year of flood, the total membership of the Trade Unions is ascertained to have been slightly over one and a half millions. During the next three years both trade and membership declined, but by I90I the numbers had risen to nearly two millions. ${ }^{2}$ At the present time, a period of considerable prosperity in trade, accompanied by acute industrial conflicts, has coincided with a remarkable growth in the membership of the Unions, which now it has been calculated embrace some three million workers. It is probably a fair estimate that one worker in five of the adult men belonging to the classes from which the Trade Unionists are drawn is at the present time a member of a trade society.

The period of growth in the Trade Union movement at

1 History of Trade Unionism. S. \& B. Webb. Introduction, p. xxxvi.

2 Ibid., p. xxxiv. 
the close of last century was remarkable for the extension and consolidation which took place in Employers' Associations. One of the most notable of these is the Engineering Employers' Association, which was originally formed on the Clyde, but gradually extended its membership to employers in other districts, and has developed into a national association of considerable strength. Efficient organisation stood the masters in the engineering trade in good stead in the struggle with the Amalgamated Society of Engineers in 1897-8. An important point with regard to the dispute was that the employers demonstrated that the regulations and conditions of production upon which the Unions insisted operated as checks to efficiency. The men were shown to have opposed new processes and the introduction of machinery, and also to have objected to working the machines at full speed. Public opinion was on this occasion definitely against the Union, and finally, after a prolonged strike, the society was driven to accept practically the whole of the employers' terms. The employers in the cotton trade, and in the mining and shipping industries, have likewise formed important societies, and in February I9I I about I, I I I associations of employers were in existence.

During recent years a strong tendency has been manifested within the Trade Union movement towards the creation of federations, and the absorption of the smaller societies by the larger. The aim has been to gain a stronger strategic position by the force of numbers, and the welding of societies extending over a large area. Obviously a threatened dislocation of industry in a trade dispute becomes increasingly formidable in proportion to the size of the area affected, and the number of persons liable to be involved. Consequently, in years of growing 
dissatisfaction and disillusionment, the principles of federation, whereby to secure greater power in " direct action," have received increasing attention. The signs of the times certainly appear to indicate that there will be a progressive massing of the forces of both wageearners and employers in the future, and such massing will necessarily set in motion greater energies for good or evil. The movement towards large federations can only be beneficial if accompanied by a heightened sense of responsibility for the larger issues which are involved, and an increased knowledge of the economic basis of wage-service.

In addition to this tendency to mass forces within the individual trades, there has also been a great impulse towards the formation of national Trade Union organisations.

Until the close of the last century the Trade Union Congress was the unchallenged representative body of the movement, but in 1900 the Labour Party was established, with directly political aims. It includes within its membership some one and a half millions of Trade Unionists, and two Socialist bodies-the Independent Labour Party and the Fabian Society. The sole object of this federation is to promote and support the candidatures of Labour Representatives in the House of Commons. With regard to the effect of the payment of Members of Parliament upon the Labour Party in the near future, it is not unlikely that it will tend to weaken the discipline in the party, and also to lessen the control which has been exercised by the Unions.

Another national organisation which embraces the societies of diverse industries was founded in 1899 . The General Federation of Trade Unions acts in the capacity 
of an insurance society, in the matter of trade disputes to its constituent Unions. By means of raising small contributions from a large number of members, it is enabled to give effective financial assistance to any Union which is involved in an important and costly trade dispute. Its object, as outlined by its founders, was to form a strong central organisation and to gather together the scattered forces of the movement: "welding them into a well-ordered and definite army capable of concerted movement, and backed by a gigantic central fund, the whole of which would be at the service of any society fighting to maintain its existence or improve the lot of its members."

\section{RECENT LEGAL DECISIONS}

The history of Trade Unionism during recent years has been greatly influenced by two important legal judgments, which have been delivered in the Taff Vale case and the Osborne case.

The events which led up to the Taff Vale judgment were briefly these : In August 1900 the organising secretary of the Amalgamated Society of Railway Servants declared a strike, and the Cardiff railway station was picketed to prevent the importation of "blackleg" labour. Mr. Richard Bell, the general secretary of the Union, gave notice to the Taff Vale Railway Company that all negotiations with the employees were to be conducted through him; the Union thus assumed a position of responsibility. ${ }^{1}$ On August 30 th the Company brought an action in the Queen's Bench Division against the Society in its registered name. The claim was for damages, and for an injunction to be made to restrain

1 Trade Unions. G. Drage. p. 189. 
the Union, its agents, and others acting under its author ity, from watching and besetting the Great Western Railway Station at Cardiff, and the works of the Taff Vale Company. The Union claimed that the Society was not a corporation, nor an individual, and hence was not liable to be sued. The action was carried beyond the Queen's Bench to the Court of Appeal, and finally to the House of Lords. The Lords reversed the judgment of the Court of Appeal, and upheld the finding of Mr. Justice Farwell, and thereby determined that a Trade Union, registered under the Trade Union Acts of 1871 and 1876 , could be sued in tort ${ }^{1}$ in its registered name, and was liable for injuries inflicted by its members. The Union was ordered to pay the sum of $f_{2} 2,000$ for " conspiring to induce breach of contract, and to interfere by picketing and other unlawful acts." Lord Lindley's emphatic opinion may be quoted: "I entirely repudiate the notion that the effect of the Trade Union Act of $187 \mathrm{I}$ is to legalise Trade Unions and confer on them rights to acquire property, and at the same time to protect the Unions from legal proceedings, if their managers or agents, acting for the whole body, violate the rights of other people. For such violation the property of a Trade Union can unquestionably, in my opinion, be reached by legal proceedings properly framed." The loss of the supposed immunity of the Trade Unions to conduct trade disputes, without rendering their funds liable for the tortious acts of themselves or their agents, was regarded as a severe blow by the leaders of the movement.

After a few ineffectual attempts had been made to

1 A tortious act is an injury to an individual which falls short of being criminal, but admits of a civil remedy. Libel, slander, malicious injury to property, boycotting, malicious prosecutions, are torts for which an individual can obtain redress. 
obtain the assistance of Parliament on behalf of the Unions, a Bill was introduced in 1905 , at the instance of the Parliamentary Committee of the Trades Union Congress. The official spokesmen for the Bill entirely repudiated any desire to possess the extraordinary powers which were conferred upon the Unions by the Trade Disputes Act of the following year. ${ }^{1}$ Sir Thomas Whittaker expressly declared, with regard to the question of " peaceful picketing," that all the Unions desired was to secure the right for a limited number of men to attend, and peacefully, without violence, without threat, without intimidation, to meet men at the railway station, or in the street, or wherever they can find them, and argue with them and persuade them not to go in and take their places. He urged that it could not be legal for a great crowd to attend, watch and beset a house, without attempting to persuade: and that " a large number of men attending could not contend that they were there peacefully to persuade." Mr. John Wilson, the other official spokesman for the Unions, in claiming some immunity for the Union funds, repudiated any desire to make the Societies irresponsible for their actions, and said: "If the executive committee of an organisation, or an organisation itself, deputes a man to do a thing which may be wrong, I have no objection to its being made liable, because then it is the Union itself that is doing wrong."

Parliament the following year discarded the recommendations of the Majority Report of the Commission, which had been appointed in 1903 to inquire into the subject of trade disputes, and passed the Trade Disputes Act, which not only failed to place any reasonable

${ }^{1}$ See Constitution Papers, August 15th, 1912. 
limits upon picketing, but entirely nullified the effect of the Taff Vale judgment. ${ }^{1}$ The lack of a sense of responsibility which has been recently so painfully obvious in the actions of some of the Unions, the violence and organised intimidation which have been manifested in some cases to non-unionists, are both, I believe, in a measure directly traceable to the fact that the Legislature in 1906 placed the Trade Unions in a position of exceptional privilege. To relieve the trade associations, which possess great powers, of their concurrent responsibilities was to court disaster. It may be confidently asserted that some of the recent expressions of Labour unrest would have been of a different character, and the Trade Unions would hold a fundamentally stronger position, and a higher place in the public estimation to-day, had the Act which was placed on the Statute Book in 1906 embodied the expressed wishes of the representatives of the Trade Unions in the House of Commons in 1905.

If the effect of the Trade Disputes Act has, as I believe, been to promote irresponsibility, the violation of agreements and contracts, tyranny and violence to non-unionists, and anxiety, distress, and suffering among the poorer classes, I believe also that one of its most

1 This Act provided that: "An action against a trade union, whether of workmen or masters, or against any members or officials thereof on behalf of themselves and all other members of the trade union in respect of any tortious act alleged to have been committed by or on behalf of the trade union, shall not be entertained in any court. Nothing in this section shall affect the liability of the trustees of a trade union to be sued in the events provided for by the Trade Union Act, 1871, section 9, except in respect of any tortious act committed by or on behalf of the union in contemplation or in furtherance of a Trade dispute."

The House of Lords judgment, in Vacher and Sons $v$. the London Society of Compositors, has established that the immunity given to Trade Unions under this Act extends beyond the area of a trade dispute. 
serious results has been the injury which it has inflicted on the prestige, and the value of the work of organised Labour. If Trade Unions are to continue to prove valuable to the working classes and the community generally, they must be accorded neither more nor less than absolute justice, and should abandon all claim to preferential treatment.

For Trade Unionists to oppose reasonable legislation defining their powers and responsibilities, and restraining the abuse of picketing, would, in my view, with regard to the future of organised Labour be a profound mistake. It is impossible for the community to permit the licence to continue which has rested with, and in some instances been greatly abused by, the Unions during the past few years. As matters stand at present, the unchecked actions, resulting from the unstable policy of some of the Unions, serve to bring the whole movement, in spite of its past records of usefulness, into disrepute.

The litigation which resulted in the Osborne judgment extended over two years, and aroused wide-spread interest. The plaintiff, Mr. W. V. Osborne, sued his Trade Union on the plea that one of its current rules was ultra vires and illegal. The rule in question provided for an enforced levy of contributions from the members of the society towards the payment of Members of Parliament, pledged to observe and fulfil the conditions imposed by the Labour Party. Mr. Osborne finally won his case, and compulsory levies by Trade Unions for Parliamentary purposes were declared to be illegal.

In I9IO an agitation was started by the Labour Party to obtain the reversal of the Osborne judgment. At the present time (February I9I3) the Trades Unions (No. 2) Bill, a Government measure, after making a somewhat 
stormy passage through Committee, has passed its third reading in the House of Commons. The Bill permits Trade Union funds to be used for political purposes, provided the members of the society, by a majority on a ballot, agree to this course. The rights of the minority, who may object, are to be safeguarded by their being given power to exempt themselves on signing a form of notice. Any member who may feel himself aggrieved by the action of his Union is afforded the right of appeal to the Registrar of Friendly Societies for protection. The Bill, on the one hand, does not entirely satisfy the Labour Party, who demand the absolute reversal of the Osborne judgment, and claim that the Unions should possess full powers to carry out any lawful policy upon which the majority may decide. The Bill has, on the other hand, provoked antagonism on the part of those who object to the Trade Unions taking political action at all, or who mistrusted the efficacy of the precautions to protect the minority, which were embodied in the Bill as originally drafted. On the whole, it appears to me that the Bill offers a just solution to a difficult question. To attempt to throttle the political aspirations of the Trade Unions would, I cannot but feel, be unjust as well as inexpedient. The pendulum has swung within the Trade Union movement during the last thirty years from extravagant hopes from the remedial powers of Parliamentary action to some distrust of constitutional methods, and in some quarters there have even been symptoms of an inclination to rely, in obedience to the Syndicalist, on revolutionary action and the general strike. Our experiences of the results of this impulse certainly do not support the view that to deny the Unions the power of engaging directly in 
political work would operate for the welfare of the nation. It is very necessary that the voice of Labour should be heard in the House of Commons, in order that the needs of the wage-earners may be expressed by men acquainted by actual personal experience with the conditions of working-class life. Without the machinery of the Trade Unions, men with the requisite social and industrial knowledge may find no road into a Parliament which should be representative of all classes, and not least of the largest class.

As time elapses and experience grows, we may look to each Labour Member, whilst retaining his sympathy for all that affects Labour, to take a wider outlook with regard to affairs of national importance, and so to contribute his share in the work of statesmanship. To fear the growth of the political power of the world of Labour, on account of its connection with Socialistic ideas, is strangely faint-hearted. May we not rather hope that the working-classes, by the wise use of voluntary associative effort, coupled with power and opportunity to voice their increasingly articulate opinions and desires in Parliament, will find the true channel between the Scylla of Socialism, and the Charybdis of Syndicalism?

\section{SYNDICALISM}

Those who sow the wind reap the whirlwind, and the whirlwind of Syndicalist thought and action is inevitably reaped in sufferings, humiliations, and bitterness of spirit.

The discontent which gave Syndicalism its rebirth has been world-wide. Scarcely a single European country has escaped during the past few years from some serious manifestations of Labour unrest, neither 
has America been exempt. Among the pre-disposing causes which have produced this discontent has been the fact that an increasing proportion of the people have become town-dwellers, which has served to afford opportunities for organised effort and to bring the workers and their families into contact with higher educational opportunities, which evoke new aspirations for a fuller and wider life. Cheap literature and facilities for travelling have served to give wings to working-class thought. The Labour movements of France have been eagerly watched by the organised Labour of Sweden, Germany and England. The representatives of Unions and Syndicates have visited the Labour leaders of foreign lands, and the interchange of views, though not without a real value in breaking down race-barriers, and welding a force pledged to promote the peace of nations, has not fostered industrial peace. The growing recognition of the solidarity of Labour of all lands has served to give the workers a widened mental horizon, and to induce them to take an increased interest in international affairs, but there can be no doubt that the anarchic doctrines of the Syndicalists have found some acceptance in country after country, as a consequence of the Labour entente cordiale, and the new facilities for interchange of opinion. A significant illustration of the fraternal interest felt by the French miners in the welfare of British Labour was given when they laid down their tools in a brief " complimentary" strike, as a sign of sympathy for the workers who were affected by the industrial struggles in our own mining districts.

The unrest in England which has given Syndicalism some foothold, is, as I attempted to show in Chapter 
XIII, the result of a keen recognition that the economic progress of the workers has been arrested: that the organisation of Labour, political action, education, and all that democracy had been taught to believe constituted the sure road of progress, have failed to secure, during the last few years, a larger share of wealth for the wage-earners. Two generations of steady advance in the condition of the artisans, and all higher grades of Labour, have been followed by a sudden check. The massing of forces for political and trade purposes, in the Labour Party, and in federal organisations, has proved unavailing to withstand the downward trend of real wages during a period of unusual prosperity.

In addition to the disillusionment with regard to the efficacy of political action, and the normal operations of Trade Unionism, there has also been a revulsion of feeling against the State Socialism of our own day. The dream of the Socialists of the past, that some great revolution was to reform society as we know it, break down the barriers of class, level opportunity, obliterate privilege, and, above all, sweep away wage-service, has gradually given place during the past few decades to an uninspiring form of collectivism. Socialism has progressively lowered its aims, and has lost its hold on the imagination. The worker now sees, instead of the irridescent bubble which formerly danced before his eyes, the vanishing remnants of the soap-suds lying on mother-earth: the colour has gone, the glory has departed. Instead of the transformed social order which the idealists painted for him, and which he was led to anticipate might appear at any time with the suddenness of a vision by night, he is told that his hopes lie in the gradual " nationalisation" and "municipalisa- 
tion" of industries, and that in the State of the future the wage-earner will still be required to work under the orders and the control of others, and will as ever fail to receive in full the product of his labour. The British working man, nourishing $d u$ fond a shrewd suspicion of the advantages to be gained by placing himself under unlimited bureaucratic control, and with the dissatisfaction of the Post Office, the telephone, and in some instances the municipal employees, well in mind, fails to appreciate the proposals of State Socialism.

The effects of the threefold disillusionment with regard to political action, Socialism, and collective bargaining, have been confusion within the Trade Union ranks, suspicion of the responsible leaders, defiance of the authority of the central executives, and for a time at least, in some quarters, a partial acceptance of the anarchic teachings and methods of Syndicalism. The Trade Union movement has shown itself, throughout the whole course of its development, singularly prone to fall captive to sudden waves of thought and impulse, but perhaps no influence which has hitherto affected the movement has been so unfortunate in character as that which found its way to England from France in I9Io.

Syndicalism is avowedly revolutionary both in its aims and methods. The object is to secure the control and possession of the whole instruments of production for organised Labour. Each group of industrial workers is to assume control of the industry with which it is connected-the railwaymen of the railways, the miners of the mines, and so on. Monopoly for the workers in each trade is to supersede competition. In so far as the aim is to acquire the management of industry by persistent working-class efforts to gain the necessary 
efficiency to control productive enterprises, it is entirely laudable, and indeed but a revival of the high ideal of the Christian Socialists. Unfortunately, however, we hear but little of the preparation required to manage successfully even a simple process of manufacture. The Syndicalist, with his inflated aims, instead of attempting step by step all that is practicable in this direction, would make the whole world of industry his; and in order to capture it frankly declares for a class war for the benefit of the operatives. Repudiating any recognition of the social organism as a whole, he argues from the assumption that there are but two classes in the community under the competitive system-the exploiter and the exploited. Eschewing all knowledge of economics, and discarding its theories, he resolves to remould industry from top to bottom. Refusing to avail himself of political action, or to take advantage of the ordinary methods of Trade Unionism-arbitration, conciliation, trade boards and the like-he advocates reliance on the primitive weapon of force.

The Syndicalist has two suggestions for destroying the industrial fabric as we know it. He proposes to supersede the occasional strike, with its legitimate use as the last resort in collective bargaining, by the "general strike," whereby to paralyse simultaneously all processes of production and distribution. He also proposes to undermine the success of competitive industry by harassing and injuring employers, until their businesses can no longer be worked with profit. The weapon of the "general strike" is to be used on so huge a scale as to change permanently the whole social order. Mr. Tom Mann declared in January, I9I2: "We shall prepare the way as rapidly as possible for 'The General Strike' of 
national proportions. This will be the actual social and industrial revolution. The workers will refuse any longer to manipulate the machinery of production in the interests of the capitalist class, and there will be no power on earth able to compel them to work when they refuse." 1 The theory of the "general strike" is, as in the days of Robert Owen, that the whole body of labourers, by simultaneously suspending work, may destroy the capitalist system and become the masters of the situation. Organised Labour would then resume the work of the world on its own terms, and in its own way.

The two ways of preparing for the "general strike" are by organisation, and by practice in guerilla warfare. As regards organisation, the aim is first to capture the Trade Unions and "amalgamate them into industrial bodies capable of taking action at all points of an industry; secondly, to bring into closer relations the different industrial organisations of every country, and at the same time to bring about an international affiliation and co-operation." Until organisation has reached the stage at which the "general strike" may prove practicable, "open fights" are advocated as a means whereby the workers, whether they win or lose, may learn their powers and their shortcomings, and how to extend or counteract them. ${ }^{2}$

The French Syndicalists have unblushingly dethroned reason. Georges Sorel, a French exponent, has declared that: "Man has genius only in proportion as he acts without reflection." The "general strike" is consequently to be the outcome of inspired feeling rather than of cool calculation. The future of the social order, when

1 Tbe Syndicalist, January, 1912.

2 Englisb Review, June, Igr2. "Syndicalism." Odon Por. F. M. Atkinson. 
the catastrophic effects of the organised paralysis of work have taken place, has received but little attention from the French Syndicalists. The present structure is to be razed to the ground, but they have designed no coherent plan for the building which is to take its place. An exponent has veiled the future with a convenient tinge of mysticism. In refusing to explain how society is to be governed after direct action has done its work he states: "I wait to decide whither I am going until I shall have returned from the journey, which will itself have revealed whither I am going." 1

The projected social order of the Syndicalists having received but little consideration, it is not surprising to find that the impracticability of the "general strike" has also been disregarded. The Syndicalist ignores the practical difficulties of organising Labour sufficiently to make the proposed plan in any way effective. He forgets that in Great Britain even if organised Labour could at the present time be moved by a common impulse and induced to act as one man, strikers would merely represent one-fifth of the operative class. Can any sane person conceive of the remaining four-fifths consenting to adopt or acquiesce in the suicidal policy? Again, no responsible government would permit the economic trial of strength to be fought $a$ outrance. Moreover, the Syndicalist should reckon with the fact that long before the struggle had made any appreciable mark upon the employer, the capitalist, or even the middle-class home, the pressure of distress upon both artisan and unskilled labourer would become insupportable. Though the working-classes exhibited, during the prolonged coalstrike, an unexpected reserve force, and I may add a

1 L'Action Syndicaliste. Victor Griffuelhes. 
self-control that was beyond all praise, neither the one nor the other could be maintained for many days during a "general strike."

With regard to the guerilla strike, the experiment in class war, it should not be forgotten that the misuse of the power to withold labour as the last resource in collective bargaining depreciates the productive power of the country in a manner which inevitably tends to sap resources and to lower rather than raise wages. Syndicalist action is wholly anti-social, and it would inflict its cruellest injuries on the very classes which it aspires to raise.

In addition to openly advocating the method of the " general strike," the French Syndicalist also recommends the use of the "Irritation" or "Pearl" strike, and has freely recommended "sabotage," or the wilful destruction of machinery. The Pearl strike is a particularly immoral and insidious way of trying to injure the employer. We have been informed that its success depends " on the men holding clearly the point of view that their interests and the employers' are necessarily hostile. Further, that the employer is vulnerable only in one place, his profits! Therefore if the men wish to bring effective pressure to bear, they must use methods which tend to reduce profits. One way of doing this is to decrease production while continuing at work." 1 The ways of diminishing production and profits are of course manifold, and have been enumerated by a leading French writer. Bad workmanship, dawdling, causing breakages through faulty packing, inserting sand in machinery, and other methods of injuring employers have been suggested by those who believe in the Pearl

1 The Miners' Next Step. p. 27. 
strike. ${ }^{1}$ Continual agitation in favour of, or for increasing, a minimum wage, and shortening hours of work until the whole of the employers' profits are absorbed, have also been advocated as a means of undermining the competitive system.

To what extent Syndicalism has influenced Trade Unionism in Great Britain is not easily gauged. Those who have studied the Labour disputes of the past two years will find it impossible to deny that the virus of class-hatred has been fostered by Labour agitators; and the doctrines of an essential and eternal war between Capital and Labour, the employer and his men, which are the main planks in the Syndicalist platform, have been preached within the Trade Union movement. The large number and quite unprecedented scale of the strikes which have occurred since the beginning of the year I9II, the temper in which some of the disputes have been conducted, the number and the importance of those which have been produced as the assertion of or in defence of Trade Union principles, all mark a grave change, and an increased aggressiveness in Trade Union policy. Though Syndicalism has received but little official recognition from the working-class organisations in Great Britain, yet the unwholesome influence of its teachings appears to me to have been by no means inconsiderable. Syndicalism is rather a result than a cause of Labour unrest, but a partial acceptance of Syndicalist teaching, coupled with the unfortunate policy which promoted the Trade Disputes Act, appears to have been prominent amongst the causes which have given an ugly colour to some of the manifestations of discontent.

There is reason to hope that the influence of Syndi-

1 Emile Pouget. Le Sabotage. 
calism will be short-lived. The strike is, I believe, already again somewhat discredited. The misery which has been caused by prolonged strikes over a wide area has suggested to the imagination something of the sufferings which would be visited on the working-classes were it possible to promote a general strike. When the impracticability of Syndicalist aims, and the essential dishonesty of its most widely advocated methods, are recognised by the wage-earners, there can be little doubt that the appeal will fail.

If we have once arrived at the conclusions that working class progress has received a check ; that neither Syndicalism nor Socialism offers a practical solution to the industrial problems; and if we believe in the boundless possibilities for good which rest with the Spirit of Association, it remains for us to attempt to find in that direction a sure line of advance. Many of our workers have not yet come into their kingdom, but their kingdom should not be sought, neither can it be found, by violence. While sweated industries still maintain a parasitic existence, while the whole standard of industrial morality requires to be raised, while inadequate wages turn the lives of thousands of our people into one dreary round of ceaseless toil, the one word to which we must steadfastly refuse to listen is the word-Halt ! 


\section{CHAPTER XVIII}

\section{THE LINE OF ADVANCE}

IN attempting either to weigh the value or to criticise the manifestations of Trade Unionism, with a view to endeavouring to find some more sure line of advance, it is necessary to guard against making sweeping generalisations. The subject is a highly controversial one, and has seldom been regarded dispassionately. Whereas some advocates and writers appear only to see the merits of the Trade Union movement, some critics have dwelt perhaps somewhat too exclusively on the defects. Both historical evidence, and the witness of the industrial events of our own day, clearly demonstrate that good and evil have always been inextricably blended in Trade Unionism, throughout the two centuries of its chequered existence.

The extreme difficulty of forming a just estimate of the value of the movement to our national and social life, is due to the fact that Trade Unions work sometimes with, and sometimes against, economic laws. They contain, simultaneously, sources of weakness and sources of economic strength. In some respects the Unions have 
made for stability in trade, and, conversely, some of them have at times shaken the equilibrium of industry. Though in some ways Trade Unionism has proved a powerful factor in raising character, and developing self-respect and independence amongst workmen, it has also in some of its manifestations tended to undermine efficiency, and has even here and there fostered dishonesty.

The subject is rendered yet more complex by the fact that the Trade Unionism of one decade is not necessarily the Trade Unionism of the next. Moreover, the guiding principles and methods of one society may be almost diametrically opposed to the aims and rules of another existing at the self-same period. There is, therefore, frequently not only some conflict of aim between the Trade Unionism of successive generations, but also between individual societies at one and the same time. The whole movement may be compared to a river with backwaters, eddies, falls, whirlpools, and rapids, and the task of the critic is to attempt to determine whither the main current is flowing.

One of the chief reasons for the variations in the societies is that the type of Union which is evolved is primarily determined by the size of the contributions which the members can afford. Up to the present time the balance is on the whole in favour of the societies which are able to take a wide view of their scope of utility, and serve other purposes in addition to their militant duties. It may here be suggested that the Insurance Act should operate to strengthen and steady Trade Unionism. Not only has the membership already been largely increased, but it may be hoped that the fluctuations in membership, in the societies which seek approval and undertake the administration of benefits under the Act, 
will diminish; and it is probable that the policy of such societies will gain in stability.

Variations in type in the societies are also largely caused by the character of the personal influence which happens to be in the ascendant in any particular Union or group of Unions. If the controlling spirit be a Ben Tillett the policy will surely differ widely from that animating societies controlled by such a man as Thomas Burt. If the success of a Union largely depends upon the type of official to whom the association entrusts the reins of office, the fact serves to emphasise how extremely difficult is the task of leadership. A leader has to satisfy exacting and sometimes insubordinate men. His task is to strive to work with employers whilst remaining ever mindful of the claims, temper and desires of the members. He must attempt to reconcile transcendental aims with the stern facts of industrial life. He should be a master of opportunity, and requires both a sound knowledge of the current condition of the trade with which he is connected, and a shrewd judgment as to its probable future developments. In addition to all this, when the question of a strike arises, he must watch public opinion, which is frequently instrumental in deciding the issue.

The action of individual societies at any given time also largely depends upon its reserve funds. A well-filled war-chest naturally gives confidence to the leaders in formulating claims on behalf of their members, and if Friendly benefits, as a motive to induce caution, are absent, the men themselves are often prone to feel that large funds, if called into requisition in support of a dispute, over a comparatively trifling matter, will serve at any rate to secure a holiday.

It may also be noticed that the policy of Trade 
Unionism as a whole, at any given period, is largely determined by the condition of trade. The alternating cycles of Labour unrest and quiescence are closely connected with the fluctuations in commercial prosperity. A rising trade barometer helps and may justify an aggressive policy by quick success : a few victories are decisive: The dissatisfaction that follows upon reaction and the consequent decline in the volume of trade and employment may be greater, but it usually subsides by force of economic circumstances into a period of industrial peace, even though discontent may remain rife.

That forces are pulling in contrary directions within the movement cannot be disputed, but a few illustrations may serve to emphasise this point which is sometimes overlooked. With regard to the treatment of nonunionists, absolutely divergent policies are recommended by different societies. The Amalgamated Society of Engineers, the Steam Engine Makers' Society, and the United Machine Workers' Association, for instance, recommend all their members not to object to working with non-unionists, whereas many societies have adopted so entirely contrary a policy, that stoppages of work have been frequently occasioned by the insistence of the officials that their men must not be employed side by side with non-union men.

Again, with regard to the attitude adopted by Trade Unions to employers, we may detect great variety in both policy and principle. Some Unions make no claim to interfere with the employers' choice of men, whilst some others insist not only that the employer shall engage Union men, but decree that the man selected by the society is to be automatically appointed to each vacancy. The Boilermakers and Iron and Steel Ship- 


\section{THE “CA' CANNY" POLICY}

builders' Union, as I have already shown, undertakes to compensate employers for any loss caused by bad workmanship, or breach of faith on the part of the members. The City and West End Cooks and Carvers are reported to have power " to fine heavily the member who does not give satisfaction to his employers." Other societies in this trade similarly reserve the right "to treat proved inefficiency as a punishable offence."1 This attitude appears to be rare, and as its counterpart we may mention the gleeful statement made in $T$ be Miner's Next Step, that one way of destroying profits and injuring the employer is to decrease production while continuing at work. The author states that "quite a number of instances where this method has been successfully adopted in South Wales could be adduced." In illustration, he relates that in one mine the men successfully opposed the introduction of new methods of screening coal by reducing the number of tram-loads of coal sent from each stall, from four to two. Whether this unofficial utterance should receive full credence or no, there can be no denial that the "ca' canny" policy has here and there marred Trade Union records.

In the whole matter of loyalty, too, within the movement, the true course of the stream is obscured by crosscurrents. The Unions have frequently supported one another in troublous times with noble self-denial, lending and giving distressed Unions large sums of money, whilst on the other hand " demarcation" disputes, when two Unions have claimed the monopoly of the same class of work, have often harassed employers and dislocated industry, notably in the engineering and building trades.

1 Life and Labour of the People in London. Second series. Vol. V, p. 164. Charles Booth. 
With regard to the general policy of the movement at the present time, confusion in principles, ideals, and propaganda, is very marked. While the Ship Constructive and Shipwrights' Association expresses in its report the hope that: "There will be no need for any serious labour trouble to arise which will interfere with the prosperity which we are now enjoying," the annual report of the General Federation of Trade Unions is expressing the view that: "Hopes of immediate peace are illusory. There can be no peace apart from radical change in the social system." Instances of divergencies in policy and opinion with regard to questions of apprenticeship, the introduction of machinery, and matters of discipline, might be largely multiplied, but enough has been said to prove the contention that Trade Unionism is the expression of aggregate policies, which are enforced by a large variety of methods.

The consequence of these antipathetic aims is that the observations of even the friendly critic may be resented and disputed, unless the great divergence which exists in practice and principle is fully realised. The Trade Unionist may well find a policy criticised which is foreign to Trade Unionism as he regards it. In venturing therefore to suggest wherein the movement has laid itself open to criticism, and on the other hand in trying to gauge its value as a social, economic, or moral force, I would urge that the observations to be made can seldom be applied to the movement as a whole. Certain characteristics of Trade Unionism have nevertheless occurred and recurred with such frequency as to become clearly defined, and to have had far-reaching results, and to these I would direct attention. My aim is to attempt to discover whether any of the symptoms which are exhibited by Trade 
Unions account, even in part, for the check which collective bargaining has indisputably sustained, and whether by any development or alteration of the existing policy further advance may be made.

The dominant aim of the Trade Unions has been to improve the industrial conditions of their members. The movement has therefore, perhaps necessarily, been a one-sided development. Lost in consideration of the often pressing needs of a section of wage-earners, it has frequently proved unmindful of the interests of others. Blows have been inflicted by the societies not only upon other trade societies, but upon the whole body of consumers, many of whom, it should be noted, are Trade Unionists in another guise. We have recently had frequent exhibitions of one class of workers inflicting grave injuries on the community. The miners, by their seemingly reckless action, dislocated a host of other industries, and the transport workers caused widespread distress, which extended far beyond the area immediately concerned with the strike. It may be argued that such action is justifiable and the consequences unavoidable, but grave economic loss must be reckoned with.

Trade Unionism cannot be said to stand for Labour as a whole, and this is notably revealed by the attitude to the free-labourer, who is generally regarded neither as a man nor as a brother. The provocation is sore, forebearance is often exercised, but the fact is plain. The aims of Trade Unionism are therefore merely sectional, as such they must be examined, as such they should be judged. Unavoidable as this concentration of aim upon the needs of a part of one class has probably been, it has proved a source of danger, and the student of history cannot fail to note regretfully that the ideal 
has in this respect fallen markedly short of that of the Gild system. The Craft Gilds, in their efforts to benefit the general public, the employer, and the wage-earner, embraced wider aims.

The abnormally developed "class-consciousness" betrayed by some Trade Unionists, has been fostered by a lack of economic knowledge, which has led to a distorted estimate of the paramount importance of the share which manual labour contributes in the work of production, and to a lack of appreciation of the responsibility and importance of management, and all that may be designated as enterprise. The facts that enterprise, a mysterious faculty, which in its highest expressions is no less than genius, is the pioneer which opens up fresh paths, and by the introduction of new methods not only satisfies existing demands, but creates new ones, and so extends field by field the area of employment, has been largely ignored.

The attitude of mind which conceives that any one person can do a given job as well as another, has often accounted for a pitiable misconception of the facts of daily life. There will be differences in capacity as long as this world revolves upon its axis. Material opportunities may be to some extent levelled either up or down, but Nature's spiritual, mental, and physical endowments will continue to vary with each babe that opens its eyes on a puzzling world.

Trade Unionism has also frequently shown a want of appreciation of the part which Capital plays in industry. Capital may be compared to the commissariat department by means of the use of which the modern industrial army can alone hope to advance or indeed be maintained. It provides the sinews of war. Capital is not the fruit of chance, but is the result of certain essential natural 
characteristics. The skilful and the far-seeing tend to acquire property; the frugal to preserve it. Without these qualities it would not exist. The bitterness against the owner of capital, as capitalist, though he has at times abused the power its possession gives, is surely in the main unjustified. The line of demarcation between Capital and Labour, and even employer and employed, is also, it should be noticed, much less sharply defined than the common modes of speech would lead us to suppose. Beyond the vast aggregate savings of the intermediate classes, an enormous amount of capital has been accumulated by the working-class, whose members are thus capitalists themselves. A large number of manufacturers rise from the ranks of Labour, while small employers are frequently reduced to undertake wage-service. The supposed gulf between employer and employed is being constantly crossed in either direction. The picture which is painted for popular representation, of the employer as a man of wealth exploiting the services of his men, while himself contributing little or nothing to the industrial result, though it may be true enough here and there, is a travesty of prevailing industrial conditions. Though there is a growing tendency to carry on manufactures on a large scale, the small employer, whose struggle with respect to financial anxiety often beggars that of his men, still carries on a large if not the largest share of the industry of the country.

The ignoring of the palpable truth that the three factors-Labour, Capital, and Enterprise-are interdependent, and each contribute an indispensable share in creating, maintaining, and expanding our industrial structure, has been largely responsible, I believe, for the "lurking grudge" which Trade Unionism has too often 
exhibited against both the capitalist and employer. The Labour agitator, with his unjust generalisations and miserable vocabulary of "wage-slavery," "servility," " exploiter and exploited," and the like, has been in no small degree responsible for some of the most unwholesome manifestations of Trade Unionism. In certain instances it cannot be denied that the Trade Unions have undermined the efficiency, intergrity, and reliability of their members. The evil feeling which has been fanned against employers has led to what may be charitably described as the sub-conscious restriction of output, whereas this restriction has been, it is to be feared, in some instances, deliberate.

Trade Unionism has stood for the dignity of the worker, and has without doubt done much to raise it. It has been largely responsible for the disappearance of the old idea that labour may be bought and sold with little regard to other considerations than those which apply to the sale of raw materials. It has, however, been too of ten forgotten that to hew out coal in the mine, or to perform the strenuous task of the stevedore, is far more worthy of the brain and sinew of a man than to lead a parasitic existence in any social grade, be it high or low. Persistent emphasis has been laid on the maxim that the workman is worthy of his hire, but it has been insufficiently urged that such hire should be honestly earned, and that to increase the utility of labour is the surest basis for the increase of its remuneration.

The failure to emphasise the importance of raising the standard of efficiency is largely due to the rooted idea, which exists amongst workmen, that there is a certain fixed demand for any given commodity, and that if it is produced more rapidly either by the aid of new methods 
or machinery, or by more vigorous workmanship, there will be a consequent decrease of employment. In short, that one man's increased efforts diminish another man's chances of finding a job. It is insufficiently realised that demand is infinitely elastic in volume and elaboration, and that facilitated production not only directly benefits the consumer, but stimulates demand and consequently employment. The fact that the Trade Unions have done little directly (though it may be claimed that they have done much indirectly) to promote the capacity of the individual craftsman, or to improve the quality, or to increase the quantity of production, appears to me to leave room for progressive action. The fight for recognition, ${ }^{1}$ unless an exaggerated meaning be attached to the word, is now in most of the trades in which Trade Unionism is firmly established a thing of the past; and the energy, which has been necessarily devoted by the Unions to a mere struggle for existence, might well be applied to more constructive work. Trade Unionism might do more to support and justify its claims by insisting upon excellency of workmanship, and diligence

1 The term "recognition" is capable of widely different interpretations. It is here used as implying a readiness on the part of employers to admit the intervention of Trade Union officials, as representing the members of their Union, in discussions on terms of employment. In the Railway industry special considerations respecting discipline and public welfare have hitherto led the Companies to withhold recognition. This refusal has been a source of grievance among the minority of Railway employees who are Trade Unionists. Two generalisations may be hazarded with regard to the recognition of Trade Unionism in all industries in which it has not yet been partially, or fully, won. First, the greater the regard which is shown by the Unions for the sanctity of contracts, and the more consistent the obedience of the members to the rules of their societies, the wider is the degree of recognition which they may hope to secure. Secondly, when a large proportion of men in any employ have become members of the Union some degree of recognition will probably follow; and, indeed, in case of a strike becomes practically a necessity. 
and reliability amongst its members. Were the employment of Trade Union men a sure guarantee that the members would be not only efficient but also anxious to give their best services, little more would be heard of any difficulty in inducing or compelling employers to select Union men. In the interests of their businesses they would naturally do so. The non-unionists would also have a stronger motive for wishing to join the Unions than exists at the present time.

The topmost wage which Labour can command depends in the last resort on the efficiency of the individual worker. Organisation may serve as a powerful lever, but it still rests in large degree with each individual wageearner to work out his own salvation. Sobriety, industry, punctuality, devotion to duty, have all their value in the world's market places, and irrespective of any special or technical skill, may yet secure for their owners a sure industrial position. Progress in this direction reacts beneficially on even the lowest grades of manual workers. Each man or boy who rises from the substratum of Labour and by means of good character or acquired skill is enabled to secure a better wage in a higher grade, does something to allay the fierceness of the struggle below.

It may also be urged that Trade Unionism has to some extent tended to stereotype mediocrity. Trade Unionism is the gospel for the average workman, but its action may, and sometimes does, tend to check the artisan who is above the average in skill, strength or ability, from gaining the full fruits of his labour.

The result of the rigid insistence upon a standard wage has also diminished the opportunities of employment for the older and less efficient man. Legislation, as embodied in the Employers' Liability Act, the Workmen's Com- 
pensation Acts, the Insurance Act, and the Trade Boards Act, is likewise operating to drive from employment those who are incapable of yielding a full day's work. From an economic as well as a social point of view this matter is a serious one. It is admittedly hedged round with difficulties, but it would seem well that, both with regard to society, and to the individual, whose outlook, when condemned as "too old at forty," is a deplorable one, the Trade Unions should, whenever it proves in any way feasible, extend the practice of permitting their older men to earn less than a standard rate.

There has been a subordination of means to ends in the attitude towards non-unionists, which is open to grave objection. Whether the motives of those who do not join the Unions be considered conscientious or merely selfish; and whether the result of strength or weakness of character; whether the proportion in the number of non-unionists is due to localisation or speciality of trade, or the amount of remuneration afforded; the fact remains that the workers who remain outside the Unions are greatly in the majority.

It is easy to grasp the arguments which the member of the Union uses, when he attempts to justify his determination to accomplish by compulsion that which he fails to achieve by persuasion. The extent of his grievance should be fully acknowledged. He feels that he has saved, organised, and toiled to secure improved conditions for Labour, by which the unorganised worker often benefits, who has shown no such foresight or energy, and has made no such provision. He realises that his task is often made an infinitely harder one, his hopes being thwarted, and his sacrifices rendered unavailing, by the men who refuse to enter into union. 
Where lies the answer? May it not be found in the fact that the Trade Unionist who consents to work in a spirit of altruism is but following a perfectly natural order. The law of life is primarily the law of sacrifice-service in one direction or another is the goal and purpose of life. To sow that others may share in the reaping is one of the noblest occupations to which man may set his hand. Regarded from this standpoint Trade Unionism may become a mission, even a crusade. If the nobler expression of the Labour Movement issues from the Trade Unionists they may earn as part of their meed the knowledge of services rendered to Labour as a whole.

It is even sometimes urged that the Unions depend for their very existence on their power to compel men to join the ranks, but if violent coercion and intimidation by armies of pickets are necessary features of Trade Unionism I can only feel, whilst admitting to the full the value of the work which they have performed, they had better perish. Tyranny, compulsion, and violence are symptoms of decay, and bring their own nemesis. If any form of association can hold its own by no other means than these, its fitness to serve in the building up of the body politic is passing as a shadow.

The anti-social characteristics which have at times been exhibited by Trade Unionism are, however, wholly inconsistent with the highest aims, the best spirit and the normal expressions of the movement. He would indeed be a pessimist who would assume that Trade Unionism is incapable of ridding itself of the errors in policy and principle which have marred its records. In my previous chapters on the history, aims, and functions of Trade Unions, I have shown something of their contribution to the other side of the account. Parliamentary 


\section{SERVICES OF TRADE UNIONS}

action on behalf of the wage-earners has been successfully invoked. Labour has been given an ideal which, upon the whole, has been an ennobling one. The call to united action has given men higher interests, and inspired them with new hopes. Association has demanded personal and corporate sacrifices which have served to raise character ; it has also implied widened responsibilities, which have called for thoughtful decisions and for self-control. Trade Unionism has done much to raise the level of industrial efficiency. The energy which has been exerted towards obtaining a higher standard of sanitation, safety, and a reduction in abnormally long working hours, has undoubtedly secured conditions which have improved the productive power of the individual worker. The demands which Trade Unionism has made in these directions have also proved a stimulus to employers to exercise their highest powers and their inventive faculties. From the days when capital was thought to be lying inexcusably idle if the machinery was arrested in mill or factory during the night hours, the constant fight of the Trade Unions to secure reasonable hours of labour has had an indirect effect in improving methods of production. During the first half of the nineteenth century it was widely believed that every improvement which was required by the Factory Acts threatened trade. Enterprise was thus spurred forward to meet anticipated loss.

It may also be justly maintained that the Trade Union insistence on a standard wage has made the task of the manufacturer easier by the elimination of a most undesirable form of competition, tending to degrade the whole industry.

The claim is also made that, in addition to steadying fluctuations in wages, Trade Unions, by resisting overtime, 
may serve to steady demand, and even to check the seasonalising of trades. It is maintained that the action of the cotton operatives in this respect, for instance, has served to promote regularity in that industry, which presents a marked contrast to the irregularity in the wool-combing trade in which a different policy is pursued. In the East Riding, after each of the five wool sales, the machinery is set agoing night and day, the wool is soon used up, and employment becomes irregular. ${ }^{1}$

Trade Unionism has also made possible the organisation of measures for promoting and preserving industrial peace. The large number of conciliation boards of which mention has already been made as exercising a beneficial influence in numerous industries depend on some organisation of Labour. The same associative effort which is required to wield effectively the strike weapon, serves as a means of carrying on the negotiations which may avert the necessity for its use.

The question whether Trade Unionism has been economically successful is debatable, and perhaps hardly capable of decisive proof. The value of a great number of divergent or opposed influences require to be weighed: the financial loss to the men due to strikes, whether successful or unsuccessful; the failure of opportunities of work; contracts missed owing to instability in Trade Union action; restriction of output; opposition to the introduction of new methods and machinery; and, on the other hand, the agreements and conciliation which have averted disaster; the palpable advance in wages which individual strikes have secured; followed in many instances by a general advance applicable to unorganised as well as organised Labour. All these, need

1 Report of the Poor Law Commission, 1909, p. 314. 
to be considered, and beyond them lies the question whether there are not other underlying influences upon which, rather than on Trade Union action, the remuneration of labour has mainly depended, before a conclusive judgment could be delivered.

Prima facie, at any rate, there is much to support the view that the Trade Unions, by means of collective bargaining, have raised wages. The conditions which existed during the early years of the Industrial Revolution, the moral failure which was manifested, the indifference which was shown to the sufferings which were caused by these conditions and by inadequate wages, all help in arriving at the conclusion that organised collective bargaining is an essential factor in working-class progress. The enormous improvement which has taken place in the conditions of employment of large numbers of wage-earners during the past century, is due, I believe, in no small degree to the fact that many workers sought strength in union. The wage claim can only be effectively made by organised forces, where parties are so unevenly matched, and where the desire to secure trade under competition affords a constant temptation to reduce the cost of production.

It is evident, too, that the publicity which has been given to trade disputes through the action of Trade Unionism, has had an influence in leavening public opinion, and to some extent raising the moral standard on the question of the adequate remuneration of Labour. The growing conviction that wages constitute the first claim on industry is, in a measure, due to the fact that Trade Unionists have long preached this doctrine.

Whether Trade Unions have accomplished much or little in raising the standard rate of wages, or to what 
extent their action has affected the remuneration of Labour generally, must remain problematic, but I believe that it is well within the powers of voluntary association to achieve a good deal more in this direction. Before Trade Unionism lies the opportunity and the hope of a great future. It has been built up in the face of obstacles which have been overcome by faith, patience, courageous efforts, and often heart-breaking struggles. The bitterness engendered by past oppression should be well-nigh gone, and the future may be faced with a new hope, determination, and dignity.

I would venture to urge that it rests with the members of the Unions to exorcise the bad spirit which has prompted the failure to keep agreements, and is shown in lack of loyalty to the cause and the leaders, and which has brought discredit on the movement. More complete organisation, a higher standard of discipline, a diplomacy based on firm adherence to agreements made, and determination to exhaust all means of conciliation; and, underlying all, an honest intention of each man to give the best work that lies in him; these are the means by which wages and the whole standard of working class life may be progressively raised; and apart from which Trade Union action must surely fail in its endeavours.

I would suggest that education is one of the chief powers by which this may be accomplished. If the education of Trade Unionists and their officials in economic subjects, the history, theory and sound principles of Trade Unionism, could be effectively undertaken, the progress of the movement on reformed lines would be assured. At the present time the Trade Union officials, save in the cotton trade, undergo no qualifying or 
competitive examinations. Of the rank and file it is stated that few young workmen give any effective study to these subjects. ${ }^{1}$ If Trade Unionism is to give to the cause of Labour the utmost help of which it is capable, this lassitude with regard to the subjects which touch it most nearly must be overcome.

The underworld of Labour, with its perennial struggles, has come but little to the fore in the present volume. The Spirit of Association has hitherto failed to plumb the depths. The Co-operative Store has not reached the mean streets; the Friendly Society movement, if we except the inferior forms of thrift organised by collecting societies, has drawn its members mainly from the higher grades of wage-earners. Trade Unionism has periodically reached the agricultural labourers and unorganised town workers, but the tide has each time quickly receded.

So strong does the weight of evidence appear to me in favour of industrial organisation, in spite of the difficulties of its application to these cases, that I regard it as one of the great means by which the condition of the lower grades of Labour may yet be progressively improved. Each force which tends to raise these classes to a higher educational level, and to instil self-control and foresight, serves to bring them more and more within reach of associative effort.

The interesting experimental attack which is being made against sweating, by the introduction of a minimum wage in certain industries under the Trade Boards Act, seems likely to stimulate organisation on the part of both masters and men. The success which the Act may achieve, and its chance of extension, appear to hinge largely upon effective organisation; but it is too early to

1 History of Trade Unionism. S. \& B. Webb. p. xxxix. 
predict to what extent this Act will foster voluntary association, and to diminish the numbers of those earning a miserable pittance, upon which physical efficiency cannot be maintained. There appears, however, reason to hope that it may prove instrumental in creating a new sense of fellowship and cohesion of interest amongst the members of the community, whose perpetual struggle for daily bread seems to leave them little initiative or energy to combine. It is said, and it seems probable, that the better class of employers in the industries concerned, where the wages have been scandalously low, welcome the obligation to pay a higher wage when all competitors are forced to do the same

The contributions which employers may make towards overcoming the difficulties which beset the modern industrial world, though they hardly fall strictly within the scope of this volume, cannot be entirely passed over. Recognition, if the term be defined to mean a readiness to admit the intervention of Trade Union officials as representing their members in discussions on terms of employment, has become practically essential under the conditions in which many industries are at present carried on. Attempts to kill associative effort in the form of trade societies invariably fail. All that is summed up in the word "consideration" is due to all those who help to make the world's wealth. A careful choice of managers and foremen, in order that the men may be subjected to no overbearing or unnecessarily galling control, is a matter of the first importance if harmonious relations are to be promoted. It should also be insisted upon that responsible managers should be readily accessible when men wish to register complaints. An injustice which is not remedied acts as a canker. 
There might also well be more thoughtful arrangement and distribution of work, whereby greater regularity in employment might be assured.

The wage question, too, makes its appeal to the heart, brain, and conscience, not only of each employer, but of every member of the community. With the conditions of industrial life which Government Inquiries, Commissions and Reports have shown to exist, we cannot rest content. The demand for a sufficient wage to maintain physical efficiency and to secure decent conditions of life, has the force of right behind it. Not only should every normally equipped workman receive such a wage, but aspirations should expand; their doing so is a sure mark of a developing civilisation. When a fair wage has once been secured, periodical holidays, which it may be hoped will become an increasingly recognised charge upon industry-sufficient leisure to develop a spiritual, social and intellectual life, beyond the confines of the mill, factory or shop-should be within the grasp of every wage-earner. 


\section{CONCLUSION}

My task is concluded, and a few final observations suggest themselves. I am conscious that a number of questions of the highest importance have been raised, and that many of them have been incompletely dealt with in my attempt to tell the tale of four great manifestations of associative effort. If, however, this volume succeeds in any degree in stimulating thought, with respect to our perplexing industrial problems, I shall have attained my object. I have sought to relate facts rather than to enunciate theories. I have hoped to afford by my narrative some inducement to others to study patiently the forces, motives and impulses which govern society, and to plunge into the deep well of thought in search of Truth. By such means alone can there be any hope of finding answers, which will stand the test of time, to the grave economic and moral problems with which we are faced. I am unable to advocate any one sure panacea for the "old woe o' the world." The roots of the evils appear to me to lie too deep, and to be too closely interlocked with questions of individual character, to admit of any cure, or alleviation, by means of the mere reorganisation of the outward structure of society.

My aim, in attempting to gauge the trend and force of 364 
associative effort, has resulted from the conviction that competition cannot be regarded as a satisfactory final arbiter of fate. Valuable as the forces of competition are continually proving themselves to be, and also entirely necessary as a bulwark against the inherent evils of monopoly, it is now well-nigh universally recognised that competition is, as Arnold Toynbee declared, a force to be studied and controlled. Two agencies are prominent amongst those which may set the bounds within which it may work beneficially-legislation, and voluntary associative effort. At the present day, when there is perhaps a tendency in some quarters to over-estimate the possible efficacy of State action, it is well to turn the pages of history and to endeavour to estimate the contributions of the forces of voluntary organisations. In Great Britain we find that the Spirit of Association is interwoven with the entire fabric of our religious, social, industrial, commercial, and political life. It touches vital issues at all points. It vests itself in ever-changing guise throughout the centuries, but the principle of mutual aid which is its underlying motive, is as natural to man as is the migratory instinct to the birds, which are drawn in flocks across the seas in spring and autumn. Our whole national history is impregnated with voluntary associative effort. It has been a path-finder to the Legislature; it has built up systems of assurance which have received legislative sanction, and are now being absorbed and developed into a State scheme; it has inspired systems of public and private relief; it has befriended the arts, literature, science, medicine, and has rendered untold services to education. In all its expressions, from the vast federations of Trade Unions to the smallest gatherings of knots of enthusiasts, assembled for some altruistic 
purpose, it has had an immeasurable influence upon our national destiny.

Parliamentary action and associative effort have each at all times their respective spheres. The drawing of the line of demarcation between the two, with sure hand and judgment, constitutes one of the highest arts of statesmanship. A number of duties lie upon this border line, and over the debatable ground the constant battle of conflicting opinion is waged, and the tide of State intervention rises and retires. There can rarely be effectual amalgamation between the two agencies. Legislation may foster or may check voluntary association, but if the forces of the State enter into competition with it, or attempt to help shoulder its burdens, the spontaneous growth frequently withers, and inevitably undergoes fundamental changes. I would therefore urge upon my readers a few considerations which may have an application to the functions which lie upon this debatable ground. Voluntary association may build more slowly than legislative action, but it tends to act more surely. It is in its essence more truly democratic ; its well-spring is conviction. It is infinitely more elastic than are the crystallised results of statutory regulation, and moulds itself decade by decade and even year by year to meet new requirements. Legislation in a progressive community is continually outgrown; it lags behind, while voluntary association constantly leads the van. Our punitive laws, our prison system, our State relief, for instance, hardly satisfy the national conscience to-day. On the other hand, when the Legislature adopts the rôle of pioneer, unsupported by the real desire of the nation as a propelling force, the task it attempts too often proves beyond its powers; it merely misses the mark, friction 
results, unforeseen forces arise and defeat its ends, and the statute, which has failed to receive democratic sanction, runs a risk of being finally consigned to the limbo of inoperative laws.

To admit all this is not to deny the vital part which the State should play in the task of social reform, it is merely to suggest that before legislation checks or supplants the forces of individual action or voluntary associative effort, full consideration should be given to these, and many other factors.

The cry of the reformer is to be heard on all sides of us, and many wayfarers would seek the millennium by legislative short-cuts. The keen desire for social betterment which these aspirations represent is a remedial power, the laws which result may carry us forward; but we are thrown back again and again on the basic facts that progress can only be surely attained by the building of individual character, by the fitting of each human being to fulfil worthily life's task, and by the consequent elevation of the whole moral plane, and the ennobling of the impulses by which our home, social, and industrial relations are controlled.

$\mathrm{He}$ who seeks to find the one sovereign remedy in legislation may be compared to the man who searches for the spot from which the rainbow springs. He will look for it in vain; yet the arc which spans the sky signifies Hope. 


\section{APPENDICES}

\section{$A$ \\ COLONIAL INDUSTRIAL ARBITRATION \\ AND CONCILIATION}

\section{NEW ZEALAND}

The federation of industrial forces in Great Britain, and the consequent extension of the strike area, have caused public attention to be directed to the methods which have been adopted in Australasia and Canada for checking strikes and lock-outs.

The "Compulsory Arbitration Act" of New Zealand was passed in 1894 . Since that date it has been amended, as difficulties in its working have arisen, and it now stands as the Industrial Conciliation and Arbitration Act of 1908. It is based upon the legal recognition and encouragement of trade associations, and though Trade Unions, as such, are not recognised, they are permitted to register as Industrial Unions. The present position in New Zealand is that nearly all the organised Labour is registered under the Act.

The machinery which is provided for the settlement of disputes between organised Labour and employers is threefold: (I) The Act encourages registered Industrial Associations of workpeople and employers to enter into and file industrial agreements, specifying the conditions 
of employment agreed upon. These agreements, when registered under the Act, have the force of the law. (2) In the event of a " dispute" between a union of workpeople, and one or more employers, the difference must be taken before a Council of Conciliation. This Council consists of an equal number of representatives of employers and employed, and a Conciliation Commissioner who is a salaried State official. The Council has power to compel the appearance of witnesses and the production of evidence, but has no power to compel the disputants to accept its recommendations. If under its auspices an agreement is arrived at, it becomes legally binding for three years, unless it is superseded by another agreement. (3) If the Council fails in its endeavours to bring about an understanding, the difference is taken forthwith before a central tribunal-the Court of Arbitration. This Court consists of three members: a permanent judge, who possesses the powers and privileges of a judge of the Supreme Court, and of two members who are nominated respectively by the unions of employers and the federations of workmen throughout the Dominions. The Court has large legal powers. Its awards are binding, and render strikes and lock-outs, after their delivery, illegal. The Court has also power to levy substantial fines for breaches of awards and agreements, and also for inciting, instigating, aiding or abetting, or taking part in illegal strikes or lock-outs. It is impossible to draw any definite conclusions as to the efficacy of the Act in improving the industrial conditions in the weaker trades, and in the maintenance of industrial peace. Mr. Aves found a large variety of opinion in the course of his inquiry, and stated that: "By employers it is disliked, tolerated, or accepted; by employees it is suspected, tolerated, or 
welcomed," the different judgments being mainly due to the inherent differences in the trades concerned. ${ }^{1}$

How far it has tended to check strikes remains uncertain. New Zealand is a country which has never been the scene of frequent active conflicts. Industry may, however, be injured by a spirit of unrest and discontent, though the embers smoulder and rarely break in to flame. This spirit the Act appears to have fostered. The number of "disputes" has risen as a result of the Act. The term "dispute" within the meaning of the Act does not necessarily imply a serious condition of hostility or active strife, but is used when a list of demands is formulated by a Union, presented, and refused. Mr. Aves found that the Act tended to create frivolous demands, and that "a habit of litigious and, therefore, nonfriendly dispute" had arisen, and that the Act had helped to foster " a class of men who are real fomentors of discord; professional in the worst sense of the word, and widely regarded as active and self-interested disturbers of the industrial peace." ${ }_{2}$

\section{AUSTRALIA}

Legislative action to repress industrial conflict in Australia resulted from the first strikes which were conducted on a large scale in that country in 1890 and $\mathrm{I} 89 \mathrm{I}$. As a consequence of the differences between the shearers and their employers the Labour Unions called out the maritime workers. "Industry was paralysed by the cessation of the sea-borne coal trade. Communications were held up, and commercial activity suspended."

1 Report on the Wages Boards and Industrial Conciliation and Arbitration Acts of Australia and New Zealand. Cd.4167. p. 93.

2 Ibid. p. 108. 
The effect on the public mind was to create a desire for legislative recognition of conciliation and arbitration by means of which voluntary settlements should be arrived at where possible; but when necessary, in order to avoid conflict, it was felt that arbitration should be compulsory, through national tribunals and under legal authority. ${ }^{1}$

The industrial legislation varies in the different States of Australia, but two main methods of regulation have emerged from the attempts to settle the disputes between Capital and Labour. The first is the attempt to adjust disputes by means of State tribunals of arbitration, and so to avoid strikes and lock-outs, which are in some States illegal. The second method is to regulate wages, hours of work, and terms of contract by means of a "Wage Board " system. The Wage Boards consist of representatives of both parties in the trade (they are appointed by resolution of a House of Parliament), and have power to make "determinations" regarding wages, which are enforced under severe penalties by the Factories and Shops Department. The compulsory Arbitration Laws in force in Australia at the present time are :-

South Australia: The Conciliation Act, 1894.

Western Australia : The Industrial Conciliation and Arbitration Acts, 1902, 1909.

Commonwealth: The Commonwealth Conciliation and Arbitration Acts, 1904, 1909, 1910, and I911. The Arbitration (Public Service Act), I9II.

Under the existing Acts employers and employed, who may be desirous of availing themselves of the legal machinery, are compelled to form Industrial Unions. An

1 Official Year-Book of the Commonwealth of Australia, No. 5. IgoI-19II. pp. 106I-1062. 
important point to notice is that these Industrial Unions (save in New South Wales) are quite distinct from voluntary Trade Unions. They are not strictly speaking voluntary associations; but are rather organisations required for the administration of the law. These registered Industrial Unions have the power to form agreements, as is the case in New Zealand. Failing agreement, disputes are settled by reference to a Court, which is presided over by a judge of the Supreme Court of the State, or, in the case of the Commonwealth, of the High Court. The jurisdiction of the Court is farreaching. It includes practically all matters concerning the relations between employers and employed. It has power to fix and enforce penalties under legal authorisation for bieaches of awards, it may provide a minimum wage; it may also (except in Western Australia) direct that preference of employment or service shall be given in any industry to members of the Industrial Unions.

Though strikes are forbidden by stringent enactment in some States, and though elaborate machinery exists throughout Australia to avert and settle disputes, yet dislocations of employment have by no means ceased, notably among the miners and unskilled labourers. In New South Wales it is recognised that the small and useless strikes have not disappeared, and an Act has been recently passed to provide a number of conveniences for more ample conciliatory tribunals.

The success of compulsory arbitration, though the soil is more congenial to it than in Great Britain, is so far only qualified. The wit of man has not yet devised legislation which will induce men to consider themselves irrevocably bound by awards or agreements, or to refrain from strikes when they are bent on rupturing contracts. 
It must be remembered, however, that the industrial legislation of Australia and New Zealand is continually undergoing processes of change. Time must elapse whilst improvements are made and tested, and before the effects are sufficiently well marked to warrant confident criticism, or sure judgments, as to the success of compulsory arbitration in the land of its birth.

\section{CANADA}

The economic conditions of Australia and New Zealand, and the whole system of industrial organisation, differ so widely from those of Great Britain that it seems improbable that the machinery of Industrial Arbitration which has been adopted in those colonies would prove either applicable or acceptable in Great Britain. Canadian legislation, however, which provides special facilities for conciliation, and yet makes no attempt to compel the adjustment of disputes, offers certain interesting features which may influence legislation in our own country.

Sir George Askwith visited Canada in 1912 to examine, on behalf of the British Government, the operation of legislation relating to trade disputes. His report to the Board of Trade [Cd. 6603] contains the result of his inquiry, and from that Report the following account is mainly drawn. In 1900 a purely voluntary conciliation measure was passed, framed largely on the British Conciliation Act of 1896 . An important dispute upon the Canadian Pacific Railway during 1902 led to the passing of "The Railway Labour Disputes Act," 1903. In 1907 a more comprehensive measure, the Industrial Disputes Investigation Act (the "Lemieux" Act) was passed, 
as a consequence of a prolonged miners' strike, which jeopardised the coal supply of Western Canada. This Act, which is now in force, differs essentially from compulsory arbitration. It recognises the right of employers and employed to terminate contracts; it does not attempt to interfere with the spontaneous voluntary organisation of industry, nor to regulate the details of the administration of business. The purpose of the Act is to secure the recognition of the interests of the public, who find themselves in the position of the most injured party, in the case of a widespread stoppage of work. "It legalises the community's right to intervene in a trade dispute by enacting that a stoppage, either by strike or lock-out, shall not take place until the community, through a Government Department, has investigated the difference with the object of ascertaining if a recommendation cannot be made to the parties which both can accept as a settlement of the difference. It presupposes that industrial differences are adjustable, and that the best method of securing adjustment is by discussion and negotiation. It stipulates that before a stoppage takes place the possibilities of a settlement by discussion and negotiation shall have been exhausted." The operation of the Act is confined to industries whose uninterrupted continuance is of high importance to the community, such as transport, mining, gas, water, electric light, etc. The "Lemieux" Act provides that any dispute arising in connection with such industries shall be submitted to a Board of Conciliation and Investigation before a strike or lock-out can be legally brought about. It is also required that at least thirty days' notice shall be given of any proposed change with regard to wages, hours, or conditions of employment. Neither party is permitted 
to cause a stoppage of work prior to or during the proceedings of the Board. The Board is composed of three members-a representative of the employers, a representative of the workpeople, and a third member nominated by both parties to act as chairman. Failing agreement on this point, the Minister of Labour appoints a chairman.

The duty of the Board is to attempt to find a basis for an amicable settlement. The Board is empowered to compel the attendance of witnesses, to take evidence on oath, and to inspect all books and documents brought before it, to employ expert assistance and to inspect workshops and factories. The finding of the Board is not binding; and when delivered, leaves the parties free to act as they think fit. There is, however, provision enabling the disputants to enter into a legally binding agreement if they wish to do so.

An employer is liable to a fine ranging from $f_{2} 20$ to $£ 200$ a day, or part of a day, for locking-out his men contrary to the Act; whereas any striker or abettor of a strike can be fined $£_{2}$ to $£_{1}$ a a day.

The Act was launched in the face of strong opposition on the part of two of the largest sections of Labour dealt with by the Act-the Western coalminers, and the railwaymen. They regarded it with suspicion as an effort to frustrate the effective use of the strike. A considerable number of objections are still raised by some Unions, but Sir George Askwith found, on the other hand, " a strong and healthy body of approval from many Trade Union officials who have had large experience of the Act." The attitude of employers appears to be at the present time, on the whole, favourable to the policy and principle of the Act. 
Sir George Askwith closes his Report with the following recommendation: "I consider that the forwarding of the spirit and intent of conciliation is the more valuable portion of the Canadian Act, and that an Act on these lines, even if the restrictive features which aim at delaying stoppage until after inquiry were omitted, would be suitable and practicable in this country. Such an Act need not necessarily be applied in all cases, but neither need it be confined to services of public utility. It could be generally available in cases where the public were likely to be seriously affected. Without the restrictive features, it would give the right not only to conciliate but fully to investigate the matters in dispute, with similar powers in regard to witnesses, production of documents, and inspection, as are vested in a court of record in civil cases, with a view, if conciliation fails, to recommendations being made as to what are believed to be fair terms. Such an Act, while not ensuring complete absence of strikes and lock-outs, would be valuable, in my opinion, alike to the country and to employers and employed." 


\section{$B$ \\ THE TRADE BOARDS ACT, 1909, \\ AND \\ THE MINIMUM WAGE}

IN 1909 an Act of Parliament was passed which established Wage Boards for certain industries somewhat on the lines of the Special Boards of Victoria. The aim of this measure is to provide a practical remedy for the evils of "sweating." The trades to which the provisions of the Act apply are: (I) Readymade and wholesale bespoke tailoring ; (2) Paper box-making ; (3) Machinemade lace and net finishing, and mending or darning operations of lace curtain finishing; (4) Certain kinds of chain-making. All workers in these scheduled trades, whether engaged in their own home or in factories or workshops, are within the scope of the Act, which thus embraces some 200,000 persons. The Act being avowedly experimental, the trades which were selected presented wide divergences in processes of manufacture, in organisation, in locality, in extent, the number of persons employed, and the degree in which they are subject to the influence of foreign competition. The Board of Trade are empowered to bring other trades within the Act by means of a provisional order, and it is now proposed to 
include shirt-making, linen embroidery, sheet-steel and iron hollow-ware, sugar-confectionery, and fruit-preserving. These are all trades which are characterised by the low wages which marked the four industries which were first dealt with.

The machinery of the Act is briefly this: A Trade Board is set up for each trade, consisting of an equal number of representatives of employers and employed, together with members appointed by the Board of Trade. Women are eligible as members, and in case of a trade in which women are largely employed, at least one of the appointed members must be a woman. In the case of an industry which is not local, but extends over a large area, the Trade Board delegate the work to district committees, on which local employers and workpeople are represented. There is also provision for the representation of home-workers when their number renders this desirable. The duty of these Trade Boards is to fix minimum rates of wages, both for time work and piece work, in the trades referred to. The rate so fixed is in limited operation for six months, during which period the employer must pay wages at not less than the minimum rate, unless there is a written agreement under which the worker agrees to accept less. After six months the Board of Trade issue an order (unless they consider a decision premature or undesirable) making the rate obligatory upon all employers. The Trade Board are empowered to take proceedings on behalf of any worker who complains of receiving less than the minimum rate. The court, upon conviction, may levy a fine not exceeding $£_{20}$, and may require the employer to refund the worker to the extent that he has been underpaid. 
If the Trade Board are satisfied that a worker, owing to infirmity or physical injury, is incapable of earning the minimum rate, they may grant him a permit enabling him to take employment on special terms.

This Act must be regarded as still in the experimental stage, and a number of factors will require the close and scientific analysis for which I pleaded in my conclusion, before deductions as to the power of the minimum wage as a remedial force may be made. The problem of the legal fixation of wages is one of infinite complication: the issues involved are not only economic, but both moral and social. The whole question requires to be considered in its widest bearings, and not only with regard to the clamorous needs of to-day, but with respect to our hopes for the industrial community of to-morrow. I would first urge that the introduction of a minimum wage in the distinctively sweated industries must not, and cannot, be regarded from the same standpoint as the attempts which are being made, and are beginning to find favour in some quarters, to secure a legal minimum wage in industries in which voluntary organisation already exists as effective machinery for collective bargaining; or where satisfactory wages have already been secured. A medicine which may well be administered to one diseased may prove unsuitable or even harmful to a person in good health. With regard to the sweated trades, it may be argued with some force that the difficulties and dangers which are inseparably connected with the regularisation of wages should be faced-and so far as may be, met-as an alternative to the degradation of health, morale, and efficiency which are the sure products of starvation wages. Much may be said to support the view that a statutory minimum wage may 
be, in such cases, hopefully applied as marking a fixed point below which wages shall not fall : a check by means of which the weight of competition shall not be permitted to become unbearably severe upon a defenceless class of workers. The Trade Boards may, in their application to sweated industries, serve to set a standard, to quicken conscience, to ventilate grievances, and to enlighten public opinion. We are, however, at the very outset confronted with a serious difficulty, and may well inquire how far the lack of elasticity, which is characteristic of all statutory regulation of this kind, will lead merely to stereotyping a low, if improved wage, and rendering defective industrial conditions more permanent. The experience of the Trade Boards has hitherto shown that the margin between the wages which were given before the passing of the Act, and those which it is possible for employers to pay, is, in some trades, by no means large. The consequence is that the rates which are fixed under the Wage Boards at the present time are certainly not rates with which adult competent workers can be expected to rest content. ${ }^{1}$

To discuss fully the pros and cons of the legal minimum wage within the limits of an Appendix is obviously impossible. I, therefore, confine myself to suggesting a few of the complicated questions which preclude any possibility of passing easy or confident judgments with regard to the success of the present Wage Boards of Australasia or Great Britain; and which serve to indicate with what extreme caution we must regard suggestions for interfer-

1 I may give as examples the minimum time-rates of female boxmakers which are fixed at $2 \frac{3}{4}$ d. an hour. In the ready-made and wholesale bespoke tailoring the time-rate for women is fixed at $3 \mathrm{dd}$. an hour, and for men at $6 \mathrm{~d}$. an hour. 
ing with wages by statute in any industries save those in which sweating is a pronounced evil.

I. One of the important points to consider is to what extent individual workers, such as the slow, the aged, or the infirm, may find their employment rendered more irregular, or may be entirely driven from industry by the establishment of a minimum wage. Mr. Ernest Aves, whose "Report on the Wages Boards and Industrial Conciliation and Arbitration Acts of Australia and New Zealand." [Cd. 4167] should be read by all who would understand the extreme intricacy of the issues involved, found that in both Victoria and New Zealand the " underrate man" tends to lose his hold on his trade. Some employers hesitate to employ the sub-average workers, for fear of the increased inspection which is liable to follow, and also for fear of being stigmatised as "sweaters" for employing men at less than ordinary rates (p. 65). That this danger is a greater one for Great Britain, on account of the superabundance of labour which exists for many forms of employment, cannot be disputed. It would, therefore, appear that whether we regard the consequence as desirable or no, any extensive application of the legal minimum wage would surely be accompanied, more especially in times of trade depression, with an increase in some form or another of State relief.

The satisfactory adjustment of the wages of those who are allowed to work under special permits constitutes one of the great difficulties which have confronted the Trade Boards. It need hardly be pointed out that the higher the Special Wage is set, the greater the danger must become of the sub-average worker failing to secure employment. If it is set unduly low, "sweating" continues. To illustrate the kind of interests which it has 
been necessary to consider in adjusting wages to operate fairly between different classes of employees, I may add that much difficulty has been experienced in " compensating the balance" to make the awards work satisfactorily as between women and boys.

One further point requires notice in connection with the permit system : It is practically impossible, as has been markedly shown in the lace trade at Nottingham, to avoid evasion of the law and collusion; and the consequent moral degeneration which results from lawbreaking.

2. The probable influence of the legal minimum wage in the struggle against foreign competition must be weighed. The fate of some trades hangs by a slender thread, and ill-considered action in such cases might speedily drive hard-pressed industries over the seas. Much will depend upon the capacity of each industry to which the legal minimum wage is applied to meet the increased charge of the wage-sheets by more economical methods of production, such as improved machinery and labour-saving devices. In industries where wages constitute a large proportion of the cost of manufacture, this consideration will naturally be of high importance. It may be argued that a consequence of the receipt of higher wages will be seen in the increased efficiency and the larger output of the workers. Though employers may be tempted to recoup themselves by "speeding-up," which may in some cases lead to overstrain, this argument is probably valid: and here, as regards the "sweated" industries, we may confidently count on a sheer gain for the workers employed. When, however, we examine the legal minimum wage in its relation to well-paid industries, where physical well-being is already provided for, we 
find that a wholly different argument applies. The lack of the necessary stimulus to the individual workman, and to the workers' Unions, might well serve to lower, rather than to raise, the standard of industrial efficiency.

3. A third conundrum which presents itself is: How far any wide extension of the Trade Boards Act, beyond the borders of the strictly "sweated" industries, might be expected to so prejudicially affect the cost of living, that all that is apparently bestowed with one hand may be withdrawn with the other ? Wages may be artificially raised in a few industries, where gross under-payment and unfair competition have ruled, with small results upon the community as a whole: whereas, a general application of the legal minimum wage principle might well bring forces into play in an unforeseen manner which might prove injurious to the very grades of society which the statutory regulation of wages has been primarily designed to help.

4. There is a great danger that legislative interference with wages may serve to widen the gulf between employer and employed and to crystallise class-divisions. A god may be made of the "cash-nexus" at the expense of the personal ties and relations which could and should improve in an age of more general education. Such legislation must also, by its very nature, check and supplant the valuable processes of spontaneous adjustment, such as voluntary Boards of Conciliation, and schemes for profit-sharing and establishing Co-partnership.

5. As to the probable influence of the legal minimum wage upon character, though we may feel that the abolition of sweating is from this point of view beneficial, it must not be forgotten that the legal regulation of wages cuts at the very roots of responsibility-a character 
builder of primary importance. Not only is the responsibility of giving a fair wage transferred from the employer by the assumption of official responsibility, but the employee loses some measure of his responsibility and incentive to gain a sufficient degree of efficiency to command his economic security. This might well result in grave loss to national stamina, and might tend to seriously curb individual enterprise. Mr. Aves' view of the results of the labour legislation in New Zealand, where the legal minimum wage plays a prominent part, is that the evidence gives conclusive proof " that present conditions in New Zealand are tending, so far as adult male workers are concerned, and over a wide field, towards a lower efficiency." (p. I09.)

6. With regard to the probable influence of the legal minimum wage upon Trade Unionism, there is much reason to doubt whether it would prove ultimately beneficial. Though Wages Boards may serve to sow the first seeds of organisation among the sweated workers who have hitherto failed to associate, yet if adopted in industries in which Trade Unionism is well established, it is probable that they would tend to weaken the action and influence of the Unions. They would obviously weaken the motives and to some extent alter the aims for which Trade Unions at present exist. When the foregoing considerations have received due attention there can be little room for doubt that the desirable end of securing a more satisfactory distribution of wealth may be best realised by the gradual growth of a higher ethical standard in industry and commerce: by the pressure of public opinion : and by the great power which may be exerted by organised voluntary forces, inspired by the highest motives of the Spirit of Association, rather than by law. 


\section{GROWTH OF NATIONAL THRIFT}

GROWTH OF THRIFT SINCE I 876

The first two of the following tables are drawn from Mr.T. Mackay's estimate in "A Policy of Free Exchange" (p. 237). The third (with the exception of the figures for Industrial Insurance Companies) is taken from the Report of the Chief Registrar of Friendly Societies for the year ending December 3Ist, I9II. (Part A, p. 4I.)

I. Estimated summary of funds of Registered Provident Societies and of Post Office Savings Banks in about the year 1876 .

Post Office Savings Bank, 1877 .

Trustee Savings Banks,

$\begin{array}{ccc}\mathbf{1} 877 & \ldots & \ldots\end{array}$ ing in the name of depositors at the Post Office, I88I (no earlier figures given)

Government stock standing in the name of depositors at Trustee Banks, I88I (no earlier figures given). .
6

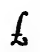

$44,238,000$ 
Brought forward ..

Building Societies, 1876

Industrial and Provident

(Co-operative) Societies, 1876

Industrial

Insurance

Companies, I880 (no

earlier figures given). .

Friendly Societies, 1876

(as estimated by

Mr. J. M. Ludlow,

Chief Registrar's Report, 1890. Part A,

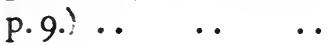

$\{73,840,000$ $20,854,000$

$6,224,000$

$1,476,000$

$9,336,000$

2. Estimate for about the year 1891 :Post Office Savings Bank,

I89I.

$671,608,000$

Trustee Savings Banks,

I891 . .

$42,875,000$

Government stock stand-

ing in the name of depositors at Trustee Banks, 1891 .. .. $\quad 5,087,000$ Government stock standing in the name of depositors at Trustee Banks, I 891 .. . . 1,282,000 
Brought forward ..

Building Societies, 1890

Industrial and Provident

(Co-operative) Societies, $1890 \quad \ldots \quad \ldots$
. $\quad . \quad \oint^{120,852,000}$ $52,482,000$

$15,261,000$

Industrial Insurance Companies, $1890 \ldots \quad \ldots \quad € 8,873,000$

Friendly Societies _. $\quad 20,167,000$

Collecting Friendly

Societies, $1889 \quad \ldots \quad 2,565,000$

$31,605,000$

$£^{220,200,000}$

3. The Chief Registrar's Summary, on December 3Ist, rgro:-

Post Office Savings Bank (including investments in stock) _. $192,042,083$

Trustee Savings Banks 65,834,706 Railway Savings Banks $6,575,945$

Industrial and Provident $264,45^{2,734}$ (Co-operative) Societies

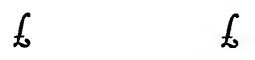

Friendly Societies, etc.. .

Collecting Friendly

Societies

Building Societies

$63,316,460$

Under Trade Union Acts

$53,105,570$

$9,760,432$ $77,261,38$ I

$5,925,358$

$\begin{array}{lllll}\text { Carried forward } & \text {. } & \ldots & \ldots & £ 473,821,935\end{array}$ 
Brought forward .. $\quad \ldots \quad \ldots \quad € 473,821,935$

Workmen's Compensation Schemes under the Workmen's Compensation Act

Friends of Labour Loan

Societies under the Loan Societies Act ..

Industrial Insurance

Companies, I9Io (from Insurance Register) . .

[See comparative summary on next page.] 


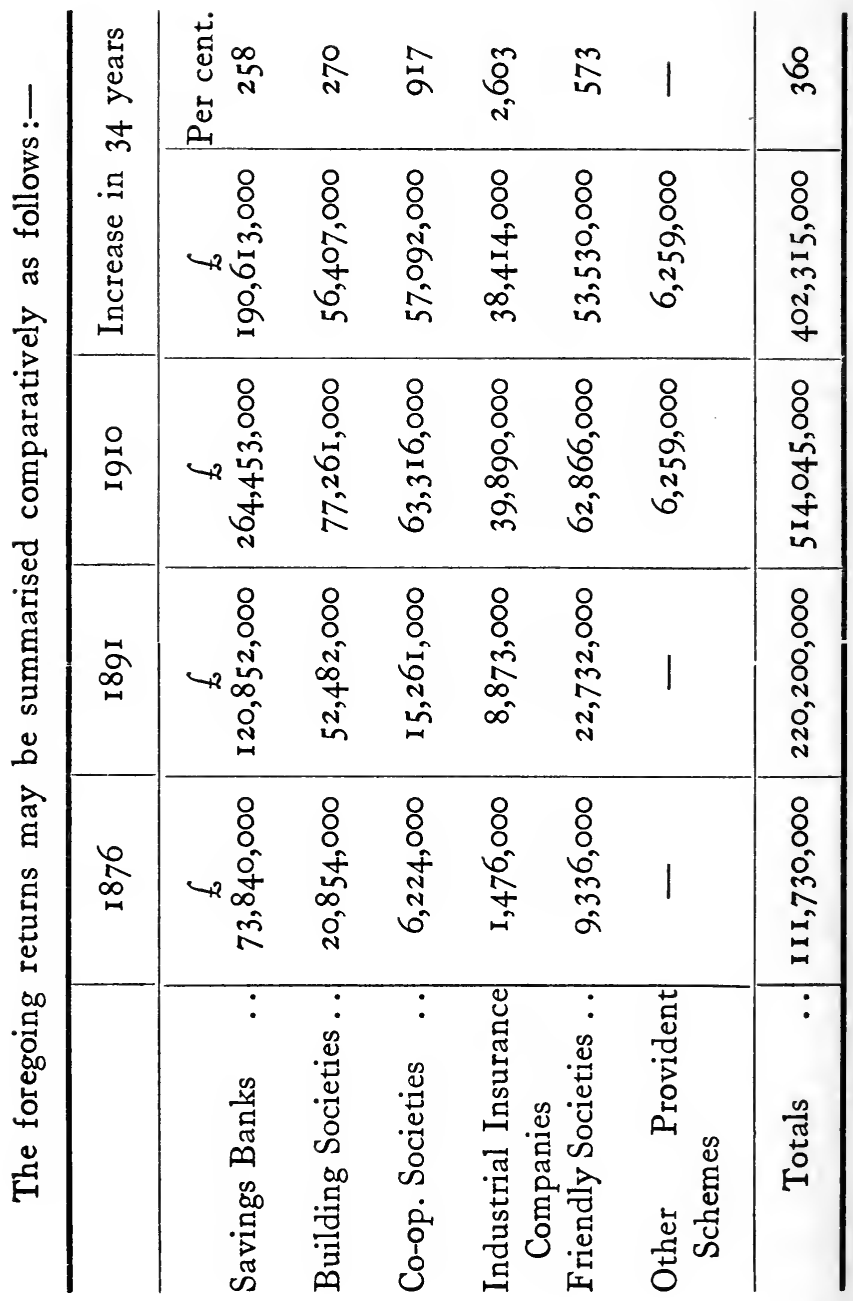




\section{BOOKS OF REFERENCE}

\section{GILDS}

Ashley, W. J. . . . Economic History.

Brentano, L. . . . Essay on the History and Development of Gilds.

Cunningham, W. . . The Growth of English Industry and Commerce.

Gould, R. F. . . . History of Freemasonry.

Gross, Charies • . The Gild Merchant.

Kropotkin, Prince . . Mutual Aid.

Lambert, J. Malet - . Two Thousand Years of Gild Life.

Leonard, E. M. - . The Early History of English Poor Relief.

Ludlow, J. M. . - . Contemporary Review, April, 1873: Gilds and Friendly Societies.

" " . . Fortnigbtly Review, 1869: Old Gilds and New Friendly Societies.

Prideaux, Sir Walter SHerburne.

Smith, Toulmin . . English Gilds.

Stow, JohN . . . Survey of London.

Unwin, G. - . . Gilds and Companies of London.

$" \quad$. . .

- Industrial Organisation in the Sixteenth and Seventeenth Centuries.

FRIENDLY SOCIETIES

Baernreither, J. M.. . English Associations of Working Men.

Brabrook, E.W. - Provident Societies and Industrial Welfare.

Cunningham, W. J. Few Observations published in Pamphleteer, 1823 .

Eden, Sir Frederic . The State of the Poor.

Hardwick, C. . . . History of Friendly Societies.

Ludiow, J. M. . . . Friendly Societies and their Congeners.

Economic Review, 1896. 
Ludlow, J. M. . . Gilds and Friendly Societies. Contemporary Review, 1873.

Moffray, W. • • . A Century of Oddfellowship, 1912.

PRATT, W. TIDD . . . Law of Friendly Societies.

Reports of the Registrar of Friendly Societies.

Wilkinson, J. F. . . Friendly Society Movement.

THE CO-OPERATIVE MOVEMENT

Aves, E. • • Co-operative Industry, 1907.

Davies, M. Ll. . . Women's Co-operative Guild, 1904.

FAY, C. R. . . . Co-operation at Home and Abroad, 1908.

Harrison, Frederic . National Problems.

HolYoAKE, G. J. . . History of Co-operation.

$"$ " . . History of Co-operation in Rochdale, 1858.

Jones, Benjamin - . Co-operative Production.

OWen, Robert . . Life of (by himself).

Plunkett, Sir Horace, Ireland in the New Century. K.C., V.O., F.R.S.

Potter, B.

- The Co-operative Movement in Great Britain.

Stubbs, Very Rev., Dean Charles Kingsley and the Christian of ELY, D.D. Social Movement.

Webb, Catherine(edited by) Industrial Co-operation.

REPORTS, ETC.

Annual Reports of the Labour Co-partnership. Association; the Irish, Scottish, and Agricultural Organisation Societies; the Women's Co-operative Guild; and a number of pamphlets issued by the L.C.A., the I.A.O.S., and the A.O.S. Co-partnersbip, the Co-operator's Year-Book (1912), and the Forty-fourth Annual Congress Report, I9I2. Report on Profit-sharing and Co-partnership issued by Board of Trade (Labour Department). [Cd. 6496.]

TRADE UNIONS.

Baerneither, J. M. . English Associations of Working Men.

Bell, R. . . . Trade Unionism, 1907.

Booth, Rt. Hon. Charles . Life and Labour in London. Second Series. Vol. V.

Clay, Sir Arthur, Bart. . Syndicalism and Labour.

Crompton, H. . . . Industrial Conciliation.

Drage, G. . . . Trade Unions, 1905.

Harrison, Frederic . National Problems, igj8.

" $"$

Howell, George . . Conflicts of Capital and Labour. 
Hutchins, B. L., and

HARRISON, A.

MacDonald, J. R., M.P. . Syndicalism.

Mackay, T. (edited by). . A Policy of Free Exchange.

Pratt, E. A.

- Trade Unionism and British Industry.

Siradiveli, Arthur, M.A., Industrial Efficiency.

M.D.

SNowden, Philip, M.P.

Watney, Charles, and Little, James A.

Webb, S. \& B.. . . History of Trade Unionism. Edition of IgII.

- Industrial Democracy.

- Problems of Modern Industry.

- What Syndicalism Means. (Pamphlet published as a Supplement to the Crusade, August, I9I 2.)

- Are Trade Unions Benefit Societies? Economic Review, I896.

Argyli, Duke of . . The Reign of Law.

CARLYLe, T. . : Chartism.

ENGErs, F. . . . Condition of the Working Classes in I844.

Factories Inquiry Commission, Reports of.

Ludiow, J. M., and Lroyd Progress of the Working Class, 1832JONES.

Marshall, A. P. - . Elements of Economics of Industry.

McCarthy, Justin . . A Short History of Our Own Times.

RAE, JohN . . . Contemporary Socialism.

Toynbee, ArNold . . The Industrial Revolution.

Wallas, Graham . . Life of Francis Place.

WISE, E. F. - . . Wage Boards in England (published by

George Allen, I9I2). 
(2) 


\section{INDEX}

Affiliated Orders, early legislation in regard to the, $148 \mathrm{et} \mathrm{seq.}$

"Agricultural Revolution," consequences of the, I03, II 8 .

Agricultural banks, 225.

Agricultural co-operation, objects of, 22I-2; success in Denmark of, 222 ; work of, in Ireland, 223, in Gt. Britain, 227.

Agricultural labourers, hard lot of, 133 ; bitter grievances of, 270 ; great organisation of, 285.

Amusements in the Middle Ages, 93.

Ancient Greece, societies of, Io. Apprentices, chastisement of, 86 ; oppression of, 91 .

Apprenticeship, very ancient custom of, 88 ; periods of, 89 ; statutes relating to, $89, \mathbf{1 2 3}$; restriction of, $89,252,274$, $3 \mathrm{II}$; riots against excessive, 254 ; decline of, 309.

Arbitration and Conciliation, distinction between, 303 ; in hosiery and iron trades, 304-5; colonial working of, 369-77.

Arbitration, in the Gilds, 22 ; in France and in England, 303-4; Trade Union rules regarding, 303 ; some objections to, 306 ; limits to usefulness of, $3 \circ 9$.
Askwith, Sir George, report on Canadian conciliation laws by, 374-7.

Assize of Bread, the, 83 .

Associative effort, achievements of, 3 ; an appreciation of, 5 ; continuity of, 100 ; Gild contribution to, rog.

Australia, industrial legislation in, $371-4$.

Benefit work : difference between Gild and Friendly Society, 29; Gild regulations regarding, 3 I ; Friendly Society, 138 et seq.; Trade Union, 288 et seq.

Board of Trade, successful intervention of, 307-8.

Boy Labour, problem of, 312 ; a mistaken policy regarding, 313-I4.

Burial Societies, 166.

"Burying Alive," the custom of, 164 .

"Butty" system, operation of the, 132.

Canada, industrial legislation in, 374-7.

Capital and Labour, line of demarcation between, $35^{\mathrm{I}}$.

Capital, part played in industry by, $35^{\circ}$.

"Captains of industry," rise of, 250. 
Character (individual), value of, 354 ; progress dependent on, 367.

Chartism, six points of, 194 .

Chauntries, description of, 25.

Child labour, exploitation of, 122, 125-8; legislative restriction of, $125^{-6}$.

Christian Socialists, the, 196-9.

City Companies, liberality of, 97 ; powers still possessed by, 107 .

Coercion and intimidation, condemnation of, 356 .

Collecting societies, 166 .

Collective bargaining, lost faith in normal methods of, 235 ; former law prohibiting, 259; effect of legalising, 284; strong argument for, 300 ; enormous improvement due to, 359 .

Combination laws, enactment of, 148-9, 259; repeal of, 150 , 263; Francis Place and, 262.

Commerce in the eleventh century, 43.

Competition, evils of unrestricted, 120 et seq. ; the control of, 365 .

Conciliation Act of 1896 , provisions of, 307 .

Conciliation-see Arbitration.

Conspiracy and Protection of Property Act, 283.

Co-operation, first efforts at, 190-3; law formerly against, 192 ; accomplishments of, before 1863,203 ; benefits of, 210 ; value to the nation of, 2II; an attempt to reach poorest class by, 215 .

Co-operative employees, treatment of, 216-20 ;

Co-operative housing, 209.

" labour conditions, 220.
Co-operative movement, objects and motives of, 18 I-2; "Magna Charta" of, 198 ; where it has failed, 214.

Co-operative production, 206.

"Productive Federation, 209.

Co-operative Societies, trade of, 207 ; accumulated funds of, 211.

Co-operative thought, two schools of, 207.

Co-operative Union, foundation and composition of the, 207 ; educational work of the, 212 .

Co-operative Wholesale Societies, foundation of, 205 ; management of, 206.

Co-partnership and ordinary Trade Union conditions compared, 243.

Co-partnership, characteristics of scheme of, 239-40; examples of, 240-I, 244; Socialist dislike of, 246 ; benefits of, 246 ; hopeful future for, 247 .

Cost of living, rise in, 234 .

"Cottage" system, operation of the, $13 \mathrm{I}$.

Cotton operatives, political power of, 298.

Cotton trade of Lancashire, organisation of the, 300 .

County Friendly Societies, 163 . Craft Gilds (or "Crafts "), origin of, $5^{8}$; relations with Merchant Gilds, 60 ; not a democratic Labour movement, $6 \mathbf{r}$; status of, 62 ; rapid increase of, 63 ; influence on medixval life of, 70 ; compulsory membership of, 73 ; production controlled by, 78 ; protection of public interests by, $80-82$; 
Friendly Society characteristics of, $9^{8}$; end of trade supervision by, 102 ; effect of monopoly policy on, 102-3.

Craftsmen, position of early, 62.

Defoe, Daniel, advocacy of Friendly Societies by, 141 .

Demand, elasticity of, 353 .

Dispute benefit, nature of, 290.

" Dividend " system in co-operation: a powerful factor, 202.

Dividing Societies, 163.

Dock strike of $1889,318,322$; leaders in the, 322.

Druids, Ancient Order of, 168.

Educational work organised by co-operators, 212-I4.

Education of Trade Unionists, need of, 360 .

Education provided by Gilds, 33 .

Efficiency, Trade Union attitude towards, 352-3; high wage dependent on, 354 .

Emigration benefit in Trade Unions, use of, 293.

Emigration funds, Trade Union, 273.

Employer, picture for popular representation of the, $35 \mathrm{I}$.

Employers, an appeal to, 247 ; the duty of, 362 .

Employers and Workmen Act, 283.

Employers' Associations, extension and consolidation of, 325.

Employers (small), effect of Industrial changes on, 120 ; financial struggle of, $35^{1}$.

Engels, mistaken prophecy of, 139.

Engineers' strike of $1897-8,325$.
Enterprise, importance in industry of, $35^{\circ}$.

Factory Act, the first, 123.

Factory children in 1832 , deplorable condition of, 295 .

Factory conditions in $1832,126$. Factory legislation, $123,125-6$, 137 ; early advocates of, 294. Factory system (early), disastrous effects on women and children of, 124 et seq. ; diseases and accidents due to, 1 28-30.

Fairs, "foreigners" trading at, 48.

Foreign demand, effect of, 103 .

Foreigners, rules to exclude, 48 .

Foreign trade in Anglo-Saxon days, 42-3.

Forestry, rise of, 147 ; early ritual of, 147 .

Framework knitting, rise of Trade Unionism in, 253.

Free Gardeners, Order of, 169.

French Syndicalists, reason dethroned by, 338 .

Friendly benefits in Trade Unions, nature of 29I ; proportion of Trade Union funds devoted to, 294, note.

Friendly benefits, unskilled Labour Unions' lack of, 290. Friendly Societies Act of 1875 , provisions of, 158 .

Friendly Societies, question of State Aid for, 2 ; early examples of, 142 et seq.; instability of, in early days, 151,161 ; public house connection with, 152 ; statutory privileges of registered, 154 ; legislation in regard to, I 56-9; elasticity of contract made by, 172 ; in 
the Colonies and America, 173-4; social value of, $175 \mathrm{et}$ seq. ; altruistic spirit of, 176 ; value to State of, 177 ; value of actuarial experience of, 177-8; failure of, where most needed, 178-9.

Frith Gilds, origin and functions of, $12-13$; procedure of, 13 ; examples of, 14-5.

General Federation of Trade Unions, objects of, 326-7.

"General Strike," the, 269; ways of preparing for, $337-8$; impracticability of, 339 .

Gild, a famous Exeter, I8.

Gild and Friendly Society benefits, difference between, 29.

Gild Courts, powers and constitution of, 85 .

Gild life, secrecy in, 12 ; varying expressions of, IO-II.

Gild movement, wide and general character of the, 34-5; first blow struck at, $35^{-6}$; effect of the Reformation on the, 38 ; remarkable influence of, 3940 ; different points of view regarding, 40.

Gild of Canute's time, statutes of $a, 17$.

Gild pilgrim, provision for the, 25.

Gild plays and pageants, 26 .

$"$ records, value of, 4 .

" remarkable independence of an early, I9.

Gild system, freedom and elasticity of, II ; inherent dangers of, $7 \mathbf{1}$; estimate of, 108 et seq.

Gilds (English), theory as to origin of, 6 ; Roman and Greek resemblances to, 7-10; chronological order of, 10; antiquity of, 12.

Gilds (Religious and Social), inquiry of 1388 into, 16 ; patron saints of, 18 ; membership of, 19-20 ; subscription, management, meeting days, etc., of, 21 ; standard of conduct demanded by, 22; arbitration in, 22 ; activities of, 23 ; some types of, 24, 26, 27; services rendered to the Church by, 27; mutual aid in, 28 ; benefits of, 30 ; almshouses provided by, 33 ; educational work of, 33 ; pious spirit of, 34 .

Gilds (Craft)-see Craft Gilds.

" (Frith or Peace)-see Frith Gilds.

Gilds of India, functions of, 41.

" (Merchant)-see Merchant Gilds.

Gilds of Kalenders, 20.

Gilds (Trade)-see Craft or Merchant Gilds.

Golden Fleece, Order of, 169.

Hearts of Oak Friendly Society, I 67 .

Hibernians, Ancient Order of, I 69.

Holidays, regulation of, 84 ; hope for general establishment of periodical, 363 .

Home worker, effect of industrial changes on the, 120.

"Houses of Call," 256, 258.

Housing, Royal Commission on, 320.

Industrial and Provident Societies Act, 198. 
Industrial Conference of 1885 , 319-20.

Industrial Council, establishment and composition of, 308 .

Industrial peace, Trade Union action in promoting, 358 .

Industrial Revolution, the, II 2 et seq.; ill-effects of, I 9 et seq.; Carlyle's condemnation of, $134-5$.

Industrial Unrest-see Labour.

Insurance Act, changes caused by the, I ; depositor contributors under, I79; a beneficial influence of the, 293; probable influence on Trade Unions of, 344 .

Jack of Newbury, story of, 104 . Journeymen's societies : nominal and real objects of, 74; complaints against, 74; decline of, in 16 th and $17^{\text {th }}$ centuries, 76 ; prototypes of the labour associations, 77; restricted opportunities of, $25 \mathrm{I}$.

Labour Agitator, mischief caused by the, 352 .

Labour Co-partnership Association, object of the, 208; report of the, 237 , et seq.

Labour Federations, movement towards large, 325.

Labour Leader, requisite qualifications of a, 345 .

Labour legislation, hardships caused by, 354-5.

Labour movement, the nobler expression of, 356 .

Labour Party, composition and objects of, 326 .

Labour representation, necessity for, 333 .
Labour representatives, the first, 286.

Labour, the solidarity of, $32 \mathrm{I}$, 334.

Labour Unrest, symptoms of, 232 ; suggested reasons for, 233 : international character of, 333; predisposing causes of, 334 .

Labourers' Unions, revival of, in the "80's," $32 \mathrm{I}$.

Laisscr-faire, results of unrestricted doctrine of, 255-6.

Land enclosure, effects of, 119.

Laws of Ine and of King Alfred, I3.

Legislation: affecting Friendly Societies, 148 et seq.; Cooperative Societies, 192, 198 ; Trade Unions, 259, 263, 277, 283 ; factories, 123, 125-6, 137; mines, 296-7.

Leprosy, prevalence in middle ages of, $3 \mathrm{I}$.

Levy Societies, I62.

Localisation of Industries, 84 .

Lord Mayor's Show: the one echo of ancient pageantry, 96 .

Macdonald, Alexander, advocacy of labour legislation by, 296.

Machinery, effect of introduction of, 104, II 5.

Malingering, early Friendly Society precautions against, 145; difficulty of checking, 167 .

Management, importance in industry of, $35^{\circ}$.

Mann, Tom, on Syndicalist action, 337-8.

Manufacture, introduction of, in England, 42 ; position of, in i8th century, II3. 
Master Builders, attempt to stamp out combination by, 276

Merchant Adventurers, origin of, 67 ; description of, 68 ; our rule in India due to, 69 ; American constitution based on procedure of, 69 .

Merchant Gilds : objects, origin and growth of, 44 ; constitution of, 45 ; contributions and management of, 46 ; exclusive nature of, 47 ; punishments inflicted by, $5^{\circ}$; religious and social work of, 52 ; position of, in Municipal Government, 53 ; stages of development of, 54 ; valuable influence of, 56 ; a present-day survival of, $65^{-6}$.

Merchants of the Staple, description of, 66; object of, 66-7.

Miners, political power of, 298.

Mines Regulation Act, the first, 296.

Minimum wage, Trade Boards and the, $378-85$; complicated questions arising in regard to, 382-5.

Moral laws, effect of disregard of, 136 .

Mundella, Rt. Hon. A. J., inventor of industrial conciliation, 304.

Mutual help, foundation stone of scheme of, 30.

"New Unionism," of the " 30 's," 267-72 ; of the "80's," 319 ; characteristics of, 321 ; impermanence of, 323 ; out come of, 324 .

Non-unionists, intimidation of, 260; ostracism of, 314-7; divergent treatment of, 346 .
Oddfellowship, foundation of, I 45 ; ceremonial, etc., in early days of, 146 .

Oddfellows, public spirited action of, 172.

Osborne Judgment, the, 331; Parliamentary action in regard to, 331-2.

Out-of-work benefit-see Unemployed benefit.

Over-production, periods of, I 34 .

Overtime, agitation against, 274 ; Trade Union action regarding, 357-8.

Owen, Robt. and Co-operation, 183 et seq.; career of, 184 ; remarkable work of, 187 ; social faith of, 187 ; mistakes of, 189 ; value of teaching of, 189 ; the dream for organised Labour of, 269.

Pageants in the Middle Ages, 93. Parliamentary action and voluntary effort, line of demarcation between, 366 .

Parliamentary action, the appeal to, 294 et seq.; exaggerated belief in, 320 ; disillusionment in regard to, 335 .

Parliamentary regulation of industry, beginning of, 105 .

Payment of members, probable effect on Labour Party of, 326.

"Pearl" Strike, description of the, 340 .

Picketing (peaceful), statements in Parliament regarding, 329.

Piecework, agitation against, 274.

Place, Francis, and the Combination Laws, 261 et seq. 
Poor Law, Gild influence on the origin of the, 29.

Production, Gild regulation of, 78.

Productive Societies (Workmen's), decline in number of, 238.

Profit-sharing, in the Co-operative movement, 217 ; characteristics of schemes of, 23940 ; Trade Union objections to, $242-5$.

Ratcliffe, influence on actuarial science of, $170 \mathrm{et} \mathrm{seq.}$

Recognition, the fight for, 353 .

Reformation, effect on Religious Gilds of, $34^{-8}$; effect on Trade Gilds of, ror.

Registrar of Friendly Societies, first appointment of, 157 .

Rochdale Pioneers, the, 199-204; remarkable success of, 201.

Roman Collegia, objects and rules of, 7-9.

Rosebery, Lord, eulogy of dock strike by, 323 .

Royal Commission of 1867 , procedure of, 279 ; recommendations of 281 ; Minority Report of, 282.

Royal Commission on Friendly Societies of $1870,158$.

Royal Commission on Labour, 1891-4, 307 .

"Sabotage," meaning of, 340 .

"Setting out the watch," description of, 95 .

Shaftesbury, Lord, on early factory evils, I 24, 130 .

Shepherds, Loyal Order of, I 68. Small Holdings and Allotments Act, usefulness of, 227-8.
Socialist teachings, danger of, 236.

Standard wage, hardships incidental to enforcement of, $354^{-}$ 5 .

State aid, tendencies leading towards, 2 ; voluntary effort checked by, 2.

St ate Socialis m, revulsion against, 335 .

Statute of Apprentices, 89 .

Statutes of Labourers, 80.

Strike, a " complimentary," 334.

Strike-ballot, advantages and drawbacks of, 302 .

Strike, of engineers in 1852 , and of builders in 1859,275 ; of agricultural labourers, 285; of dock labourers in 1889,318 , 322 ; of engineers, $1897^{-8}$, 325 ; "Pearl," 340.

Strike, the General-see "General Strike."

Strikes, in $14^{\text {th }}$ century, 74 ; in 16th century, 75; in early I 9 th century, 260, 264; Trade Union condemnation of, 273 ; proportion of Trade Union funds devoted to, 294 note; efforts towards peace which precede, 301 .

Sweating, House of Lords Committee on, 319 ; legislative action against; $36 \mathrm{I}$.

Syndicalism, growth of, 333 ; object of, 336 ; anti-social character of, $34^{\circ}$; influence on Trade Unionism of, $34 \mathrm{I}$.

Syndicalists, destructive suggestions of the, 337 .

Taff Vale Judgment, particulars of, 327 . 
Tailoring trade, rise of Trade Unionism in, $25 \mathrm{x}$.

Temperance Friendly Societies, 169.

Ten Hours' Bill, motives for supporting, 295 note.

Thrift,growth of national, 386-9o

Toulmin-Smith, Mr., researches of, $x$.

Trade Boards Act of 1909,378 85 ; probable effect of, $36 \mathrm{r}$.

Trades Councils, composition and procedure of, 297.

Trade Disputes Act, provisions of, 330 note.

Trade disputes-see Strikes.

Trade Gilds, cause of extinction of, 40, 64 ; effect of Reformation on, IOI.

Trade Union action, a criticism of, 343 et seq.

Trade Union Acts of 1871 and $1876,283$.

Trades Union Congress, procedure of, 297-8.

Trade Union officials, change in type of, 299; qualifications required by, 299, 300 ; varying types of, 300 .

Trade Union organisations, formation of national, 326 .

Trade Unions : definition, first inception and main causes of, 249; development of, 255 et seq.; rapid growth in 18 th century of, 258 ; legal suppression of, 259 ; outrages by early, 260, 266, 27r ; great organisation in 1834 of, 269 ; "New Unionism," 267-72; first legislative victory of, 277 ; benefit work of, 288-90 ; insecurity of benefits of, 292 ; some wis e regulations of, 302 ; present membership of, 324 ; effect on national and social life of, 343-4; varying type and aims of, 344 et seq. ; effect of personal influence on, 345 ; attitude to employers of, 346 ; distorted views of, $35^{\circ}$; a suggested future policy for, 353,360 ; good influence and work of, 356 et seq.; action respecting excessive working hours of, $357-8$; industrial peace preserved by, $35^{8}$; concerning economic success of, 358 ; influence on wages of, 359 Tramp money, earliest hint of, 18.

Transit, cause and effects of improvements in, $117-8$.

Travelling benefit in Trade Unions, discipline enforced by, 293 .

“Trespassers," Gild punishments for, 79 .

“Truck" system, operation of the, 13 .

Underworld of Labour, organisation of the, $36 r$.

Unemployed benefit, strong position of Trade Unions in administering, 29I ; great value of, 293 ; proportion of Trade Union funds devoted to, 294 note.

Unemployment, problem in Middle Ages of, r 10.

Union Shops (Co-operative), object of, 192.

Vagrancy, problem in Middle Ages of, IIO-r.

"Victimised" members, Trade Union support of, 290. 
Vital Statistics, 169, et seq.

Voluntary associative effort, an appreciation of, 365 ; advantage over State action of, 366 .

Voluntary societies, example to Legislature of, 3 .

Voluntary trade boards, 304 , 308.

Wage, a standard-see Standard Wage.

Wages, Trade Union action in raising, 359; the right to adequate, 363 .

Weavers, effect of industrial changes on the, rir.
Women and children, evil results of excessive employment of, 124 et seq.

Women, Spirit of Association lacking amongst, 179 .

Women's Co-operative Guild, membership, etc., of, 209 ; valuable influence of, $213-5$.

Women's work, early regulations affecting, 85 .

Working-class capitalists, $35 \mathrm{I}$.

Working-class leaders, good examples of, 276.

Working Men's College, foundation of the, 198 . 


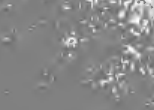




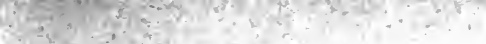




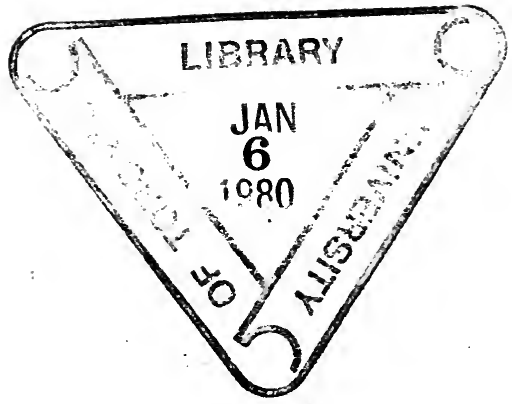

$\ldots$ 


\section{PLEASE DO NOT REMOVE CARDS OR SLIPS FROM THIS POCKET \\ UNIVERSITY OF TORONTO LIBRARY}

HD

6664 R695 1913
Robinson, M. Fothergill (Margaret Fothergill)

The spirit of association 
